\title{
Long-Term Performance of Buried Pipes Under Flowable Fill and Granular Stone Backfill
}

\author{
Sai Bharath Kumar Varre \\ West Virginia University
}

Follow this and additional works at: https://researchrepository.wvu.edu/etd

\section{Recommended Citation}

Varre, Sai Bharath Kumar, "Long-Term Performance of Buried Pipes Under Flowable Fill and Granular Stone Backfill" (2011). Graduate Theses, Dissertations, and Problem Reports. 4808.

https://researchrepository.wvu.edu/etd/4808

This Thesis is protected by copyright and/or related rights. It has been brought to you by the The Research Repository @ WVU with permission from the rights-holder(s). You are free to use this Thesis in any way that is permitted by the copyright and related rights legislation that applies to your use. For other uses you must obtain permission from the rights-holder(s) directly, unless additional rights are indicated by a Creative Commons license in the record and/ or on the work itself. This Thesis has been accepted for inclusion in WVU Graduate Theses, Dissertations, and Problem Reports collection by an authorized administrator of The Research Repository @ WVU. For more information, please contact researchrepository@mail.wvu.edu. 
Long-Term Performance of Buried Pipes Under Flowable Fill and Granular Stone Backfill

\author{
Sai Bharath Kumar Varre
}

Thesis submitted to

the College of Engineering and Mineral Resources

at West Virginia University

in partial fulfillment of the requirements

for the degree of

Master of Science

in

Civil Engineering

Hema J. Siriwardane, Ph.D., Chair

Udaya B. Halabe, Ph.D., P.E.

John D.Quaranta, Ph.D., P.E.

Department of Civil and Environmental Engineering

\author{
Morgantown, West Virginia \\ 2011
}

Keywords: HDPE ; PVC; Concrete ; Corrugated Steel; Creep ; Finite Element Analysis;

Soil-Pipe Interaction ; HS- 25 loading; CLSM; Granular Stone 


\begin{abstract}
Long-Term Performance of Buried Pipes under Flowable Fill and Granular Stone Backfill
\end{abstract}

Sai Bharath Kumar Varre

Underground conduits have been used to improve living standards of people since the development of civilization. Buried pipes are used in various applications such as highway drainage, sewerage and conveyance systems. Time dependent properties such as creep associated with thermoplastic (HDPE and PVC) and concrete materials may reduce the expected design life of pipes under field conditions. The objective of this research work was to examine the long term performance of buried pipes used in highway applications by using the finite element method. The variables investigated in this research include types of pipe material, pipe diameter, fill height, pipe backfill material, and trench width. Corrugated high density polyethylene (HDPE), solid wall polyvinyl chloride (PVC), reinforced concrete (RCP), and corrugated steel pipes (CSP) have been considered in this study. The influence of trench widths and time dependent material properties such as creep of pipe materials on the performance of buried pipes was investigated for a time period of 50 years under different loading conditions (dead and live loads).The performance of pipe under fill heights ranging from 10 feet $(3 \mathrm{~m})$ to 50 feet $(15 \mathrm{~m})$ and trench width ratios varying from 1.5 to 2.5 have been analyzed. Trench width ratio can be defined as the trench width divided by the mean diameter of the pipe. Results show that almost $60 \%$ to $80 \%$ of pipe deflections occur during the first year of installation for all the pipes. This percentage depends on the pipe material and the loads. For PVC pipes, the deflection in the first year is about $70 \%$ of the total deflection. For HDPE pipes, this percentage is $60 \%$ to $80 \%$. The results from the numerical analyses suggest that a trench width as low as 1.5 times the diameter of the pipe can be used to install pipes under fill heights up to 40 feet $(12 \mathrm{~m})$ without any failure. For PVC pipes, the fill height could be as high as 50 feet for a trench width ratio of 1.5. However, HDPE pipes exhibit the possibility of failure at 50 feet $(15 \mathrm{~m})$ burial depth under the combination of live and dead loads. Computed deflections in concrete and steel pipes are small and hence could be installed up to depths of 50 feet without meeting the pipe failure criterion. 


\section{ACKNOWLEDGEMENT}

I would like to take this opportunity to thank several people who played a vital role in the successful completion of this thesis. First and foremost, I would like to thank my advisor and committee chairman, Dr. Hema Siriwardane, for providing his valuable guidance and continuous support throughout this project. I thank Dr. Udaya Halabe and Dr. John Quaranta for reviewing my thesis and participating on my examination committee.

I gratefully acknowledge the financial support provided by West Virginia Department of Transportation, Division of Highways through a Graduate Research Assistantship through a research project funded through West Virginia University. I would like to thank my

friends, Raj Kumar Gondle, Rupesh Gondle, Benjamin Bowes, Sumanth Gundagatti, Laura Sesack and Andrew Dietz for their help and encouragement during this research.

I would like to express my great appreciations to my family for their valuable love and constant support. 


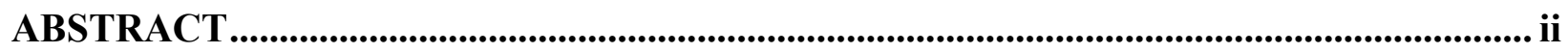

ACKNOWLEDGEMENT .................................................................................................

LIST of FIGURES ................................................................................................................................. viii

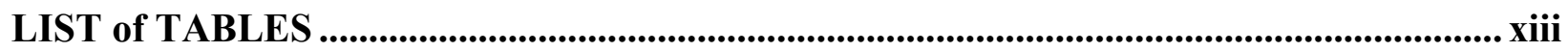

Chapter 1:INTRODUCTION............................................................................................................. 1

1.1 Background ......................................................................................................................................... 1

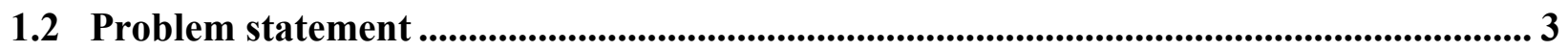

1.3 Research objectives ................................................................................................................... 4

1.4 Scope of Work ……............................................................................................................ 5

Chapter 2:OVERVIEW OF BURIED PIPE DESIGN.................................................................... 7

2.1 Introduction ......................................................................................................................................... 7

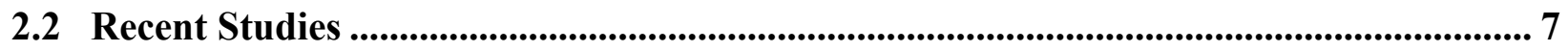

2.3 Factors influencing pipe performance ........................................................................ 10

2.4 Design characteristics of buried pipe ...................................................................................... 11

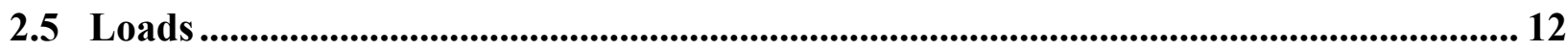

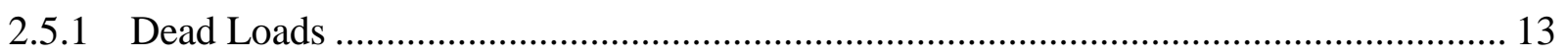

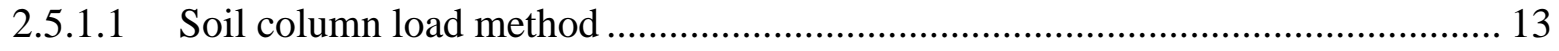

2.5.1.2 Soil arch load Method..................................................................................... 14

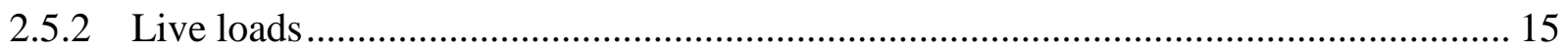

2.6 Pipe stiffness ..................................................................................................................................... 19 
Chapter 3:SOIL PROPERTIES AND THEIR IMPORTANCE IN DESIGN..................... 24

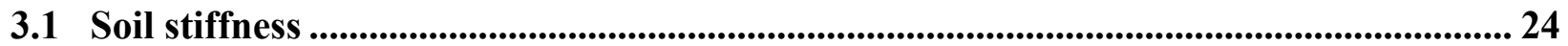

3.2 Backfill materials ................................................................................................... 27

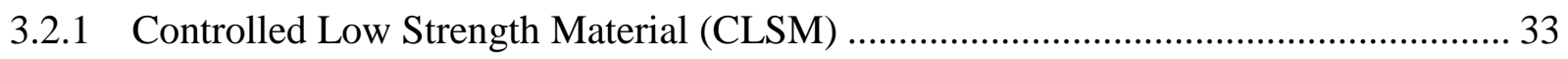

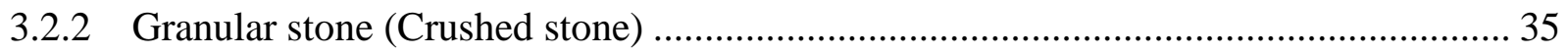

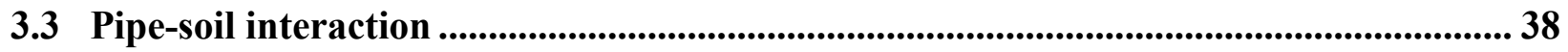

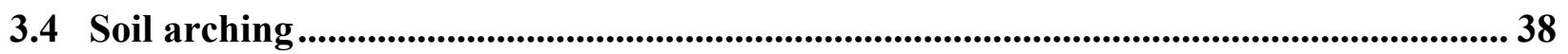

Chapter 4:CREEP RESPONSE OF BURIED PIPES ....................................................... 40

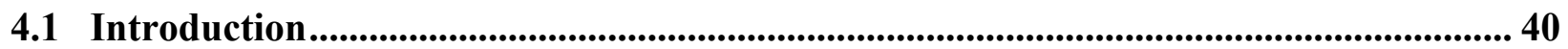

4.2 Time dependant behavior of plastic pipe materials........................................................... 40

4.3 Time dependant behavior of concrete pipe material .................................................. 42

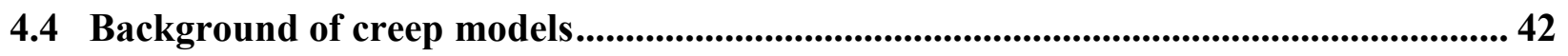

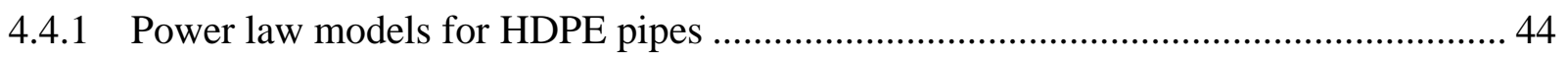

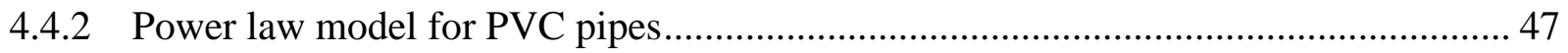

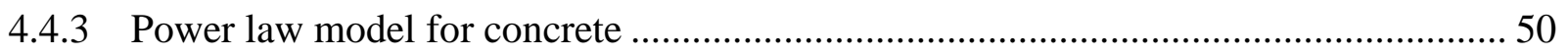

Chapter 5:PIPE MATERIALS AND ESTIMATION OF THE PIPE'S ELASTIC

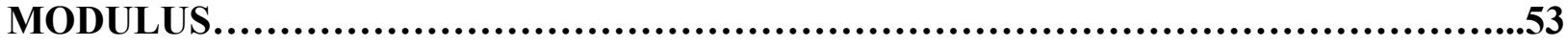

5.1 High density polyethylene pipes (HDPE) .................................................................... 53

5.1.1 Estimation of Elastic modulus of Type S HDPE pipe ............................................ 58

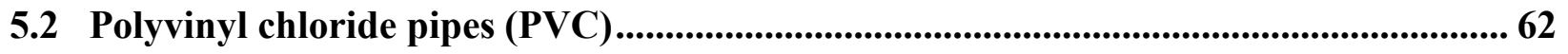

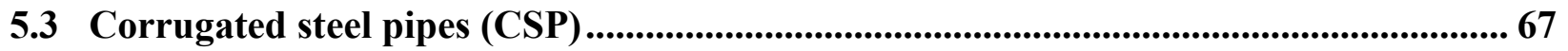

5.3.1 Estimation of elastic modulus of corrugated steel pipe with annular seams ............... 72 
5.4 Reinforced concrete pipes (RCP) ................................................................................ 76

5.4.1 Estimation of elastic modulus of steel reinforced concrete pipe .................................. 80

Chapter 6:NUMERICAL METHODOLOGY........................................................................ 82

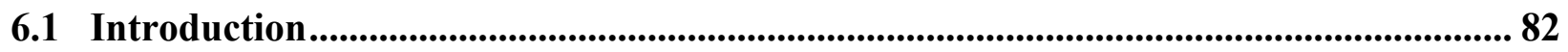

6.2 Basic principles of finite element analysis ........................................................................... 82

6.3 Finite elements used in this study ......................................................................................... 83

6.4 Loading, boundary conditions and finite element step sequence ..................................... 86

6.5 Material properties ............................................................................................................... 89

6.6 Creep formulation in finite element method .......................................................................... 91

6.6.1 High density polyethylene (HDPE) ……………….................................................... 92

6.6.2 Polyvinyl chloride (PVC) ………………………..................................................... 92

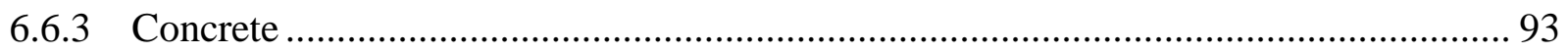

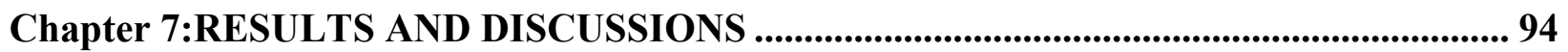

7.1 Introduction................................................................................................................................ 94

7.2 Numerical results for high density polyethylene (HDPE) pipes ....................................... 95

7.2.1 Response due to self-weight of the soil ...................................................................... 95

7.2.2 Response due to HS -25 truck loading + self-weight of the soil ................................ 102

7.3 Numerical results for polyvinyl chloride (PVC) pipes..................................................... 109

7.3.1 Response due to self-weight of the soil ................................................................... 110

7.3.2 Response due to HS -25 truck loading + self-weight of the soil ............................... 117

7.4 Validation of the time-dependent model used for HDPE and PVC .............................. 126

7.5 Numerical results for reinforced concrete (RCP) pipes ................................................... 126

7.5.1 Response due to self-weight of the sol ................................................................ 127 
7.5.2 Response due to HS -25 truck loading + self-weight of the soil

7.6 Numerical results for corrugated steel (CSP) pipes........................................................ 139

7.6.1 Response due to self-weight of the soil ............................................................. 140

7.6.2 Response due to HS -25 truck loading + self-weight of the soil ............................. 145

Chapter 8:SUMMARY AND CONCLUSION ......................................................... 153

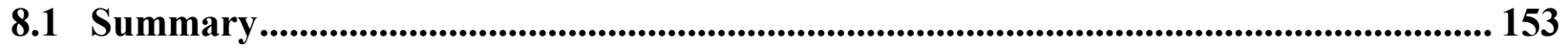

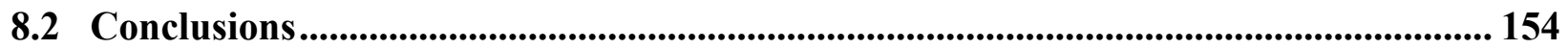

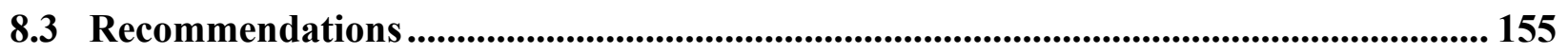

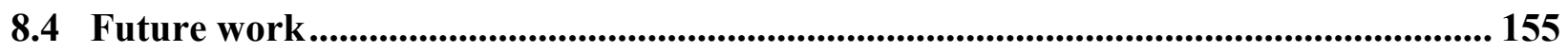

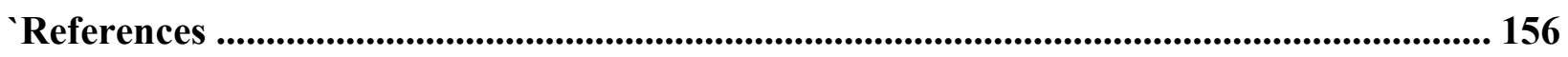




\section{LIST OF FIGURES}

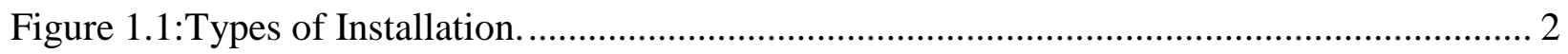

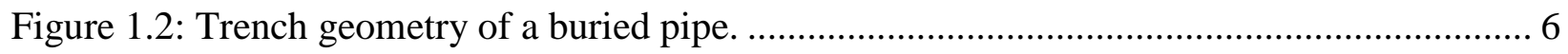

Figure 2.1: AASHTO Highway Loads (AASHTO, 2007; ADS,2009). .................................... 16

Figure 2.2: Schematic Diagram of a Three Edge Bearing Test Apparatus................................... 21

Figure 2.3: Parallel Plate Load Test and loading conditions.......................................................... 23

Figure 3.1: Spangler's assumptions to develop the Iowa formula.................................................. 25

Figure 3.2: Soil arching (Gondle and Siriwardane,2008).......................................................... 39

Figure 4.1: General power law form of time dependent creep behavior. .................................. 44

Figure 4.2: Variation in relaxation modulus of PVC with time (Modified from Janson, 1995). 49

Figure 4.3: Variation in elastic modulus with time using different power laws. (Modified from Bazant and Osman, 1976; Bazant and Chern, 1985). ........................................................... 51

Figure 5.1: Profile view of double-wall corrugated HDPE pipe. ……………………................ 56

Figure 5.2: Profile view of single-wall corrugated HDPE pipe................................................... 57

Figure 5.3: Typical cross section of double-wall corrugated HDPE pipe. ...................................... 61

Figure 5.4: Typical cross section of profile wall and solid wall PVC pipes.................................. 64

Figure 5.5: Arc and tangent corrugations(NCSPA,2008)......................................................... 71

Figure 5.6: Typical cross section of corrugated steel pipe with annular seams............................ 75

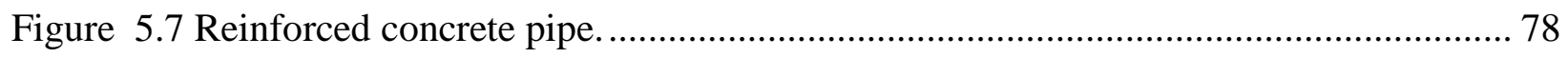

Figure 6.1: Two-noded beam element (Cook et al, 2003).......................................................... 84

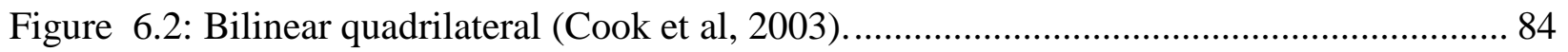

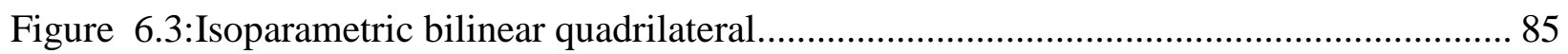

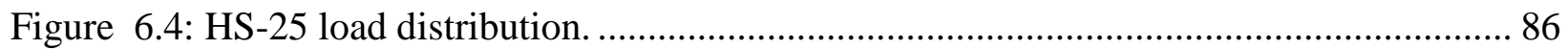

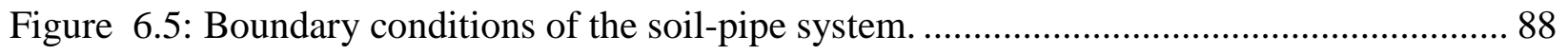

Figure 6.6: Soil properties used in the finite element analyses.................................................... 89

Figure 7.1: Fifty-year deformation in the soil-pipe system due to self-weight of the soil. ......... 96

Figure 7.2: Fifty-year vertical deflection of a 60 inch $(1.50 \mathrm{~m})$ HDPE pipe installed at a depth of 50 feet. 97

Figure 7.3: Vertical deflections of a 60 inch $(1.50 \mathrm{~m})$ HDPE pipe installed in CLSM under increasing backfill heights. 98 
Figure 7.4: Vertical deflections of a 60 inch $(1.50 \mathrm{~m})$ HDPE pipe installed in granular stone under increasing backfill heights. 98

Figure 7.5: Effect of trench width ratio of a 60 inch $(1.50 \mathrm{~m})$ HDPE pipe installed in CLSM.. 99 Figure 7.6: Effect of trench width ratio of a 60 inch $(1.50 \mathrm{~m})$ HDPE pipe installed in granular stone. 99

Figure 7.7:Fifty-year vertical deformation of various HDPE pipe diameters installed in CLSM pipe backfill. 100

Figure 7.8:Fifty-year vertical deformation of various HDPE pipe diameters installed in granular stone pipe backfill. 101

Figure 7.10: Fifty-year vertical deflection of a 60 inch $(1.50 \mathrm{~m})$ HDPE pipe due to HS-25 loading and self-weight of soil. 103

Figure 7.9: Fifty-year deformation in the soil-pipe system under HS-25 truck loading. 103

Figure 7.11: Vertical deflections of a 60 inch $(1.50 \mathrm{~m})$ HDPE pipe installed in CLSM under HS-25 load and self-weight of soil. 104

Figure 7.12: Vertical deflections of a 60 inch $(1.50 \mathrm{~m})$ HDPE pipe installed in granular stone under HS-25 load and self-weight of soil. 104

Figure 7.13: Effect of trench width ratio on vertical deflections of a 60 inch $(1.50 \mathrm{~m}) \mathrm{HDPE}$ pipe installed in CLSM under HS-25 load and self-weight of soil. 105

Figure 7.14: Effect of trench width ratio on vertical deflections of a 60 inch $(1.50 \mathrm{~m}) \mathrm{HDPE}$ pipe installed in granular stone under HS-25 load and self-weight of soil . 105

Figure 7.15:Fifty-year vertical deformation of various HDPE pipe diameters installed in CLSM under HS-25 load and self-weight of soil. 106

Figure 7.16:Fifty-year vertical deformation of various HDPE pipes diameters installed in granular stone under HS-25 loads and self-weight of soil. 107

Figure 7.17: Fifty-year deformation in the soil-pipe system due to self-weight of the soil. ..... 111 Figure 7.18: Fifty-year vertical deflection of a 24 inch $(0.60 \mathrm{~m})$ PVC pipe installed at a depth of 50 feet $(6 \mathrm{~m})$. 112

Figure 7.19: Vertical pipe deflection of a 24 inch $(0.60 \mathrm{~m})$ PVC pipe installed in CLSM under increasing backfill heights.

Figure 7.20: Vertical deflection of a 24 inch $(0.60 \mathrm{~m})$ PVC pipe installed in granular stone under increasing backfill heights. 113 
Figure 7.21: Effect of trench width on the vertical pipe deflection of a 24 inch $(0.60 \mathrm{~m}) \mathrm{PVC}$ pipe installed in CLSM.

Figure 7.22: Effect of trench width on the vertical pipe deflection of a 24 inch $(0.60 \mathrm{~m})$ PVC pipe installed in granular stone. 114

Figure 7.23: Fifty-year vertical deformation of various PVC pipe diameters installed in CLSM. 116

Figure 7.24:Fifty-year vertical deformation of various PVC pipe diameters installed in granularstone. 116

Figure 7.25: Fifty-year deformation in the soil-pipe system under HS-25 truck loading. 118

Figure 7.26: Fifty-year vertical deflection of a 24 inch (0.60 m) PVC pipe under HS-25 loading and self-weight of soil.

Figure 7.27: Vertical deflections of a 24 inch $(0.60 \mathrm{~m})$ PVC pipe installed in CLSM under HS25 load and self-weight of soil.

Figure 7.28: Vertical deflections of a 24 inch $(0.60 \mathrm{~m})$ PVC pipe installed in granular stone under HS-25 load and self-weight of soil.

Figure 7.29: Effect of trench width ratio on the vertical deflection of a 24 inch $(0.60 \mathrm{~m}) \mathrm{PVC}$ pipe installed in CLSM under HS-25 load and self-weight of soil. 121

Figure 7.30: Effect of trench width ratio on the vertical deflection of a 24 inch $(0.60 \mathrm{~m})$ PVC pipe installed in granular stone under HS-25 load and self-weight of soil.

Figure 7.31:Fifty- year vertical deformation of various PVC pipe diameters installed in CLSM pipe backfill under HS-25 loads and self-weight of soil. 122

Figure 7.32: Fifty-year deformation of various PVC pipe diameters installed in granular stone under HS-25 loads and self-weight of soil.. 123

Figure 7.33: Fifty-year deformation in the soil-pipe system due to self-weight of the soil. ..... 128 Figure 7.34: Fifty-year vertical pipe deflection of a 96 inch $(2.40 \mathrm{~m})$ reinforced concrete pipe installed at a depth of 50 feet $(15 \mathrm{~m})$. 128

Figure 7.35: Vertical deflections of a 96 inch $(2.40 \mathrm{~m})$ reinforced concrete pipe installed in CLSM. 129

Figure 7.36: Vertical deflections of a 96 inch $(2.40 \mathrm{~m})$ reinforced concrete pipe installed in granular stone. 
Figure 7.37: Effect of trench width on the vertical deflection of a 96 inch $(2.40 \mathrm{~m})$ reinforced concrete pipe installed in CLSM 130

Figure 7.38: Effect of trench width on the vertical deflection of a 96 inch $(2.40 \mathrm{~m})$ reinforced concrete pipe installed in granular stone. 130

Figure 7.39: Fifty-year vertical deformation of various reinforced concrete pipe diameters installed in CLSM. 131

Figure 7.40: Fifty-year vertical deformation of various reinforced concrete pipe diameters installed in granular stone.

Figure 7.41: Fifty-year deformation in the soil-pipe system under HS-25 truck loading. 133

Figure 7.42: Fifty-year vertical pipe deflection due to HS-25 loading and self-weight of soil. 133

Figure 7.43: Vertical deflections of a 96 inch $(2.40 \mathrm{~m})$ reinforced concrete pipe installed in CLSM under HS-25 load and self-weight of soil. 134

Figure 7.44: Vertical deflections of a 96 inch $(2.40 \mathrm{~m})$ reinforced concrete pipe installed in granular stone under HS-25 load and self-weight of soil. 134

Figure 7.45: Effect of trench width ratio on the vertical deflections of a 96 inch $(2.40 \mathrm{~m})$ reinforced concrete pipe installed in CLSM under HS-25 load and self-weight of soil..... 135

Figure 7.46: Effect of trench width ratio on the vertical deflections of a 96 inch $(2.40 \mathrm{~m})$ reinforced concrete pipe installed in granular stone under HS-25 load and self-weight of soil 135

Figure 7.47: Fifty-year vertical deformation of various reinforced concrete pipe diameters installed in CLSM under HS-25 loads and self-weight of soil. 137

Figure 7.48:Fifty-year vertical deformation of various reinforced concrete pipe diameters in granular stone under HS-25 loads and self-weight of soil. 137

Figure 7.49: Instantaneous deformation in the soil-pipe system due to self-weight of the soil. 141 Figure 7.50: Instantaneous vertical pipe deflection of a 120 inch $(3 \mathrm{~m}$ ) corrugated steel pipe installed at a depth of 50 feet $(15 \mathrm{~m})$.

Figure 7.51: Instantaneous vertical deflections of a 120 inch (3 m) corrugated steel pipe installed in CLSM

Figure 7.52: Instantaneous vertical deflections of a 120 inch (3 m) corrugated steel pipe installed in granular stone. 
Figure 7.53:Effect of trench width on the vertical pipe deflection of a 120 inch $(3 \mathrm{~m})$ corrugated steel pipe installed in CLSM.

Figure 7.54: Effect of trench width on the vertical deflection of a 120 inch (3 m) corrugated steel pipe installed in granular stone.

Figure 7.55: Instantaneous vertical deformation of various corrugated steel pipe diameters installed in CLSM

Figure 7.56:Instantaneous vertical deformation of various corrugated steel pipe diameters installed in granular stone. 144

Figure 7.57: Instantaneous deformation in the soil-pipe system under HS-25 truck loading.... 146

Figure 7.58: Instantaneous vertical pipe deflection of a 120 inch (3 m) corrugated steel pipe installed at a depth of 50 feet (15 m) under HS-25 loads and self-weight of soil 146

Figure 7.59: Vertical deflections of a 120 inch $(3 \mathrm{~m})$ corrugated steel pipe installed in CLSM under HS-25 loads and self-weight of soil.

7.60: Vertical deflections due of a 120 inch $(3 \mathrm{~m})$ corrugated steel pipe installed in granular stone under HS-25 load and self-weight of soil. 147

Figure 7.61:Effect of trench width ratio on the vertical deflections of a 120 inch $(3 \mathrm{~m})$ corrugated steel pipe installed in CLSM under HS-25 load and self-weight of soil. 148

Figure 7.62:Effect of trench width ratio on the vertical deflections of a 120 inch $(3 \mathrm{~m})$ corrugated steel pipe installed in granular stone under HS-25 load and self-weight of soil. 148

Figure 7.63: Instantaneous vertical deformation of various corrugated steel pipe diameters installed in CLSM under HS-25 load and self-weight of soil.

Figure 7.64: Instantaneous vertical deformation of various corrugated steel pipe diameters installed in granular stone under HS-25 load and self-weight of soil. 150 


\section{LIST OF TABLES}

Table 2.1: AASHTO Highway Loads Carried by Wheel Set (ADS,2009) …………..................... 17

Table 2.2: Live Load Data for HS-25 and Cooper E-80 (ADS,2009) .......................................... 18

Table 3.1: Class and Type of Soil used for Backfill Material .......................................................... 29

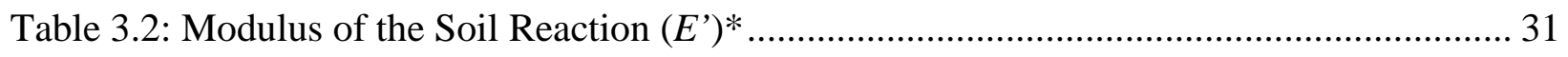

Table 3.3: Backfill Soil Properties used in Previous Studies.......................................................... 32

Table 3.4: Controlled Low Strength Material Properties Available in the Literature ................... 33

Table 3.5: ASTM Specifications for Class I Material used as Pipe Backfill*................................ 36

Table 3.6: ASTM D 2321 Recommendations for Embedment and Backfill Materials of Class I*

Table 3.7: Soil Modulus of Crushed Stone used in Previous Studies........................................... 38

Table 4.1: Comparison of Relaxation Modulus at different Pipe Ages (Janson, 1995) ................ 48

Table 5.1: Section Properties of Double-Wall Corrugated HDPE pipes (ADS , 2006) ................ 55

Table 5.2: Physical and Mechanical Properties of Solid-Wall PVC Pipes ${ }^{+}$.................................... 63

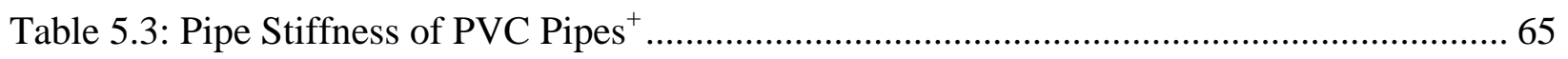

Table 5.4: Specification Data for D 3034 \& F 679 PVC pipes ${ }^{+}$.................................................... 66

Table 5.5: Shapes and Sizes of Corrugated Steel Conduits (NCSPA, 2008) ................................. 68

Table 5.6: Corrugation for Different Types of Steel Pipes (NCSPA, 2008) .................................. 69

Table 5.7: Sectional Properties of 3 inch $x 1$ inch (Annular or Helical) Corrugation (NCSPA,

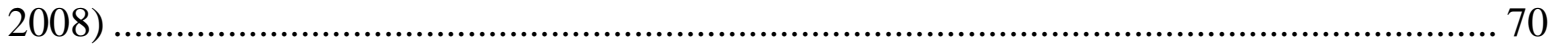

Table 5.8: ASTM C 76 Standards for Reinforced Concrete Pipe.................................................... 76

Table 5.9: Sectional Properties of Class II Reinforced Concrete Pipe (ASTM C-76, 2004) ....... 79

Table 5.10: Elastic Modulus Values Obtained from 3D Static Analyses ........................................ 81

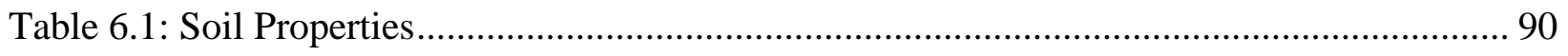

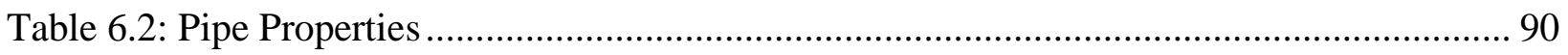

Table 6.3: Values of A, $\mathrm{n}$ and m (Arvidsson and Gronvall, 2004; ABAQUS, 2007; Gondle and

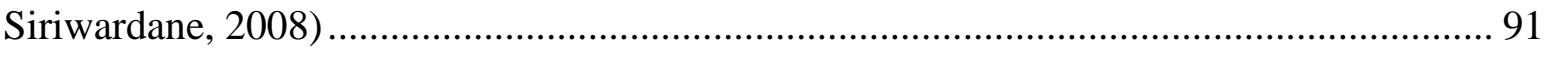

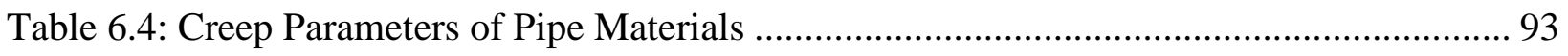

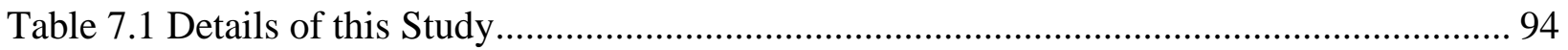

Table 7.2: Fifty-Year Vertical Deflection of HDPE Pipes Installed in CLSM ........................... 108 
Table 7.3: Fifty Year Vertical Deflection of HDPE pipes Installed in Granular Stone............. 109

Table 7.4: Fifty-Year Vertical Deflection of PVC Pipes Installed in CLSM ........................... 124

Table 7.5: Fifty-Year Vertical Deflection of PVC Pipes Installed in Granular Stone............... 125

Table 7.6: Compairision of Results from Static and Creep Analyses..................................... 126

Table 7.7: Fifty-Year Vertical Deflection of Reinforced Concrete Pipes Installed in CLSM.... 138

Table 7.8: Fifty-Year Vertical Deflection of Reinforced Concrete Pipes Installed in Granular

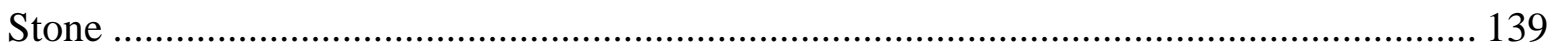

Table 7.9: Instantaneous Vertical Pipe Deflection of Corrugated Steel Pipes Installed in CLSM 151

Table 7.10: Instantaneous Vertical Pipe Deflection of Corrugated Steel Pipes Installed in Granular Stone 152 


\section{Chapter 1: INTRODUCTION}

\subsection{Background}

Underground conduits have been used to improve living standards of people since the development of civilization. Every modern city needs underground conduits such as pipes to provide necessary facilities such as waste water disposals, potable water and gas (Chua and Lytton, 1987). High quality pipe materials and well-designed underground pipeline systems are necessary to deliver quality water and transport sewage without any leakage. There are different types of pipe materials available in the market today, which are categorized into two primary classes: flexible and rigid. In buried pipe technology, a flexible pipe material is defined as the one which can deflect at least two percent without any structural distress. Flexible pipes are manufactured from plastics such as high density polyethylene (HDPE), polyvinyl chloride (PVC), and metals such as steel. Pipe materials which do not meet the above criterion can be considered as rigid (Moser, 2008). Rigid pipe materials consist of reinforced concrete, cast iron or vitrified clay. Pipe materials should be selected to meet site conditions and specified design requirements. Pipe installation requirements are dependent on the stiffness of the pipe material and the depth of embedment. Proper design and installation practices enhance the structural performance and in-service life of a pipeline.

The two most common types of pipe installations are trench and embankment as shown in Figure 1.1. A pipe buried in a narrow channel excavated in intact soil is said to be in a trench condition (Figure 1.1a). In a trench, frictional forces developed along the trench walls provide support to the backfill material over the pipe. This reduces the effect of the backfill load on the pipe. Occasionally, pipes are placed on rigid surfaces which have a wide soil fill cover (Figure 1.1b). This is known as an embankment conditions. In an embankment, the soil on either side of the pipe settles more than the soil directly over the pipe. This leads to an increase in the backfill load on the pipe. 
Finished surface

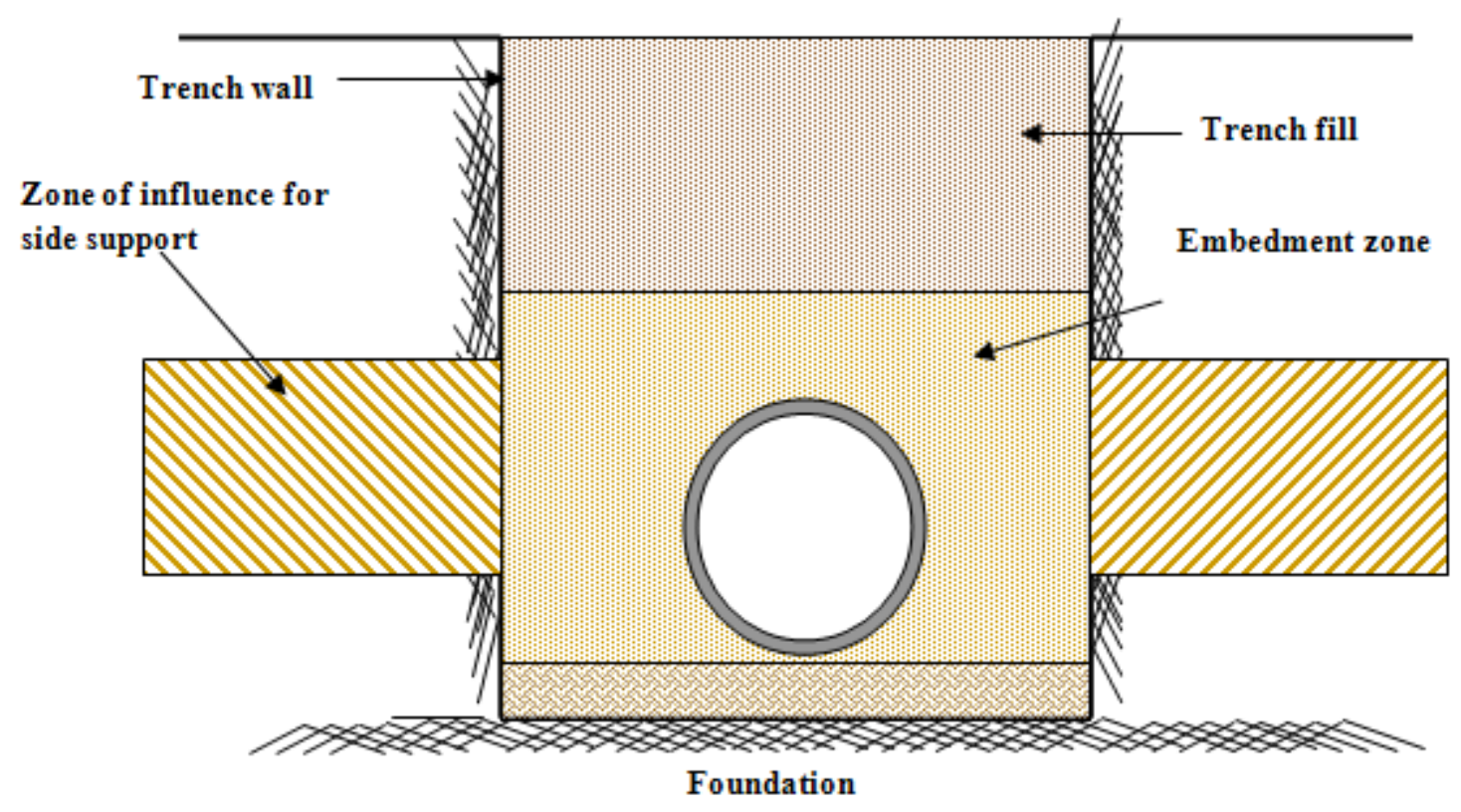

(a) Trench condition

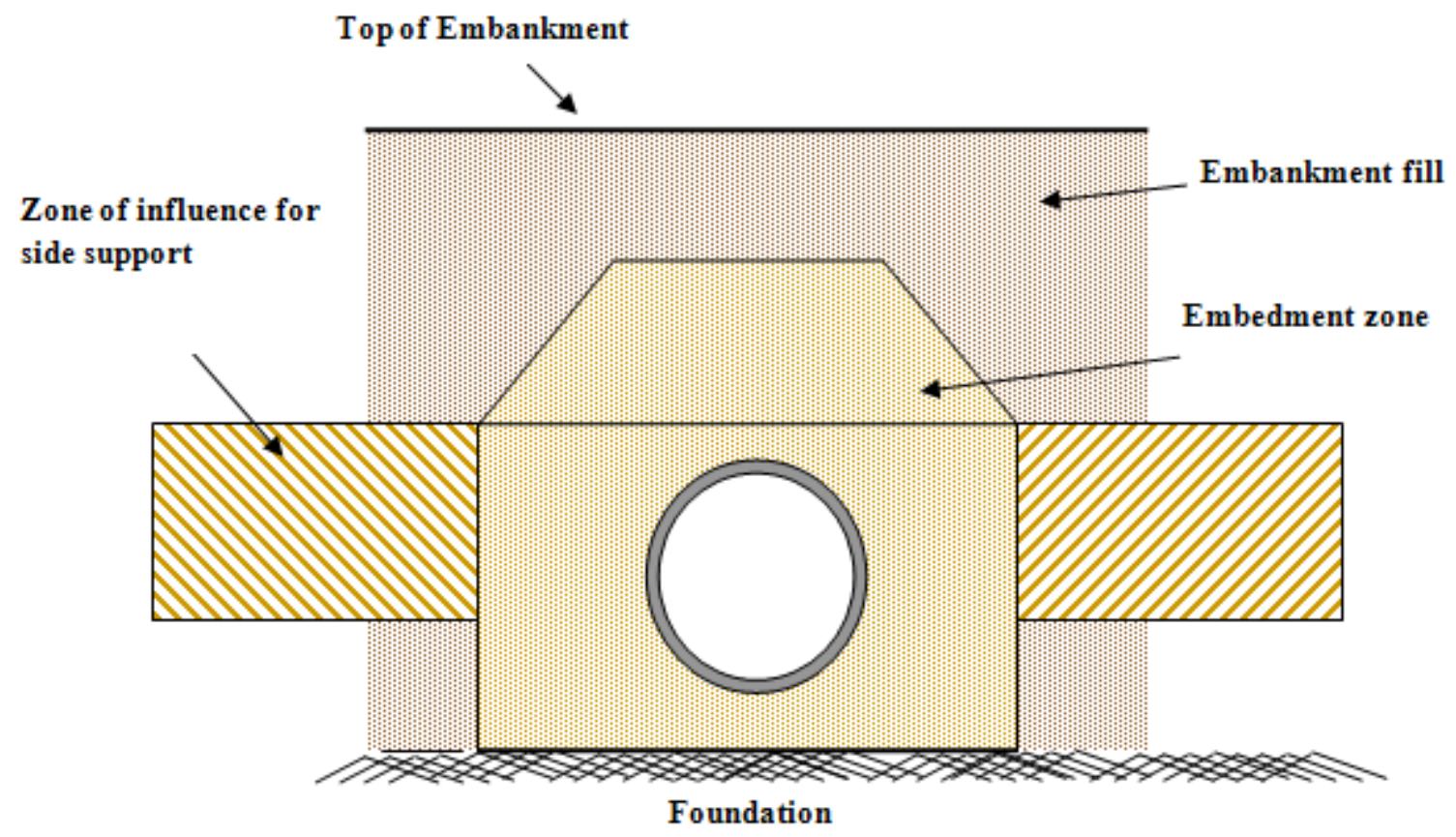

(b) Embankment Condition

Figure 1.1:Types of Installation. 
Both, the pipe and the soil mass have a significant impact on the overall performance of buried pipes. The deformation of a buried pipe is a function of loads (dead and live loads), pipe geometry, pipe material properties, and soil properties. The loads acting on a buried pipe vary with the depth of burial and the type of backfill soil. Consideration must be given to the type and the strength of soil material surrounding the pipe (ADS, 1994) and the load distribution. In the design of a rigid pipe, it is often assumed that only the vertical pressures due to the self-weight of the soil and the traffic loads have an impact on the pipe. The soil pressure in the horizontal direction is assumed to be either nonexistent or negligible. For a flexible pipe, the pipe deflections caused by the vertical load give rise to horizontal soil pressure. The load around the pipe approximates hydrostatic loads when the vertical and horizontal pressures are almost equal. The hydrostatic loads result in circumferential compressive stresses in the pipe, which may lead to buckling in cases where the pipe is installed under deep cover (Moser, 2008).

Failure of old and deteriorating pipelines can cause considerable damage to other property that might result in a significant cost. In urban areas, excavating to remove the damaged pipes and installing a new pipe can be difficult and expensive (Moser, 2008). Therefore, proper choice of backfill material, fill heights, and trench widths are important in the design of buried pipes. When designing a pipeline system for long-term service, consideration must also be given

to time-dependent behavior such as creep of pipe materials in addition to the parameters discussed in the previous section.

\subsection{Problem statement}

- Buried pipes not only deform under the self-weight of the overburden soil but also due to the visco-elastic behavior of pipe materials with time. Time dependant processes such as creep are dependent on the type of pipe material. Creep is generally exhibited by most plastic materials.

- Creep deformation of materials such as HDPE, PVC, and concrete can cause excessive deflection that can compromise the structural performance of the pipe. 
Therefore, it is important to make a realistic prediction of the magnitude of creep deformations in a pipe (Fanouraki and Ballim, 2003). In order to evaluate the performance of a pipe over a long period of time, it is necessary to incorporate the time-dependent properties of the pipe in the analyses.

- The load transmitted to the pipe is directly dependent on the height of backfill above the pipe's crown. It is important to determine the backfill depth up to which the pipe can be installed without failure. Corrections or additional maintenance after the completion of the pipeline may not be convenient (OCPA, 2010). Excavation costs are also a major concern.

- The variation in the stiffness of the pipe and the backfill soil plays a major role in the mobilization of shear strength of the soil (PPI, 2005). The evaluation of the long-term performance of buried pipes becomes more complicated when the mobilization of shear strength of soil and the time-dependent nature of the pipe is coupled.

- Trench width plays an important role in choosing a pipe as well as the class of bedding material. The backfill load transmitted to the pipe is proportional to the trench width at the crown of the pipe. Improper choice of trench width may lead to pipe failure due to excessive loads being transmitted to the pipe (OCPA, 2010). Construction of wider trenches for stiffer pipe materials may not be economical. Thus, it is important to determine the appropriate trench widths for the safe and economical installation of the pipe.

\section{$1.3 \quad$ Research objectives}

- Obtain sectional properties of large diameter flexible and rigid pipes.

- Determine stiffness parameters of pipes. 
- Perform an extensive review of literature to identify the structural behavior of pipe-soil systems.

- Identify creep models for high density polyethylene (HDPE), polyvinyl chloride (PVC), and concrete pipes.

- Perform creep (visco-elastic) analysis for large diameter flexible and rigid pipes ranging from 18 inch $(0.60 \mathrm{~m})$ to 120 inch $(3 \mathrm{~m})$ under different backfill heights ranging from 10 feet $(3 \mathrm{~m})$ to 50 feet $(15 \mathrm{~m})$ using controlled low strength material and granular stone as pipe backfill.

- Determine the effect of trench width ratio varying from 1.5 D to 2.5 D (Note: D is the mean diameter of the pipe) under various loading conditions.

- Evaluate the short-term and long-term results for the assessment of the creep response.

- Compare long-term deflections of different pipes and determine their suitability under given fill heights, backfill material and loading conditions.

\subsection{Scope of Work}

Several research studies on the time-dependent behavior of high density polyethylene, polyvinyl chloride, and concrete pipes have been undertaken in the past, and several theoretical creep models have been reported in the literature (Hashash, 1991; Chua, 1986; Janson, 1985; Janson 1995; Bazant and Chern, 1985; Bazant and Osman, 1976). It is important to study the time-dependent nature of the pipe materials under field conditions to determine the design life of a buried pipe. In this study, a finite element approach was used to investigate the time-dependent (long-term creep) behavior of corrugated high density polyethylene (HDPE), solid wall polyvinyl chloride (PVC), and reinforced concrete (RCP) pipes.

In the study reported herein, finite element analyses using ABAQUS were performed to determine the significance of creep in the long-term deflections of buried pipes under self-weight of soil and HS-25 live loads. These analyses provide information regarding the applicability of flexible or rigid pipe under various fill depths and trench widths. This information is vital from an economic point of view and provides enormous cost-cutting benefits. The two main 
components of a finite element model are the pipe and the soil system. A buried pipe can be defined as a composite system consisting of a ring surrounded by a soil envelope. In the design analyses, the soil system can be divided into three distinct zones as shown in Figure 1.2. They are the insitu soil, pipe backfill or embedment soil, and the final backfill (or the trench backfill). It was assumed that the insitu soil remains undisturbed. The pipe backfill is the soil surrounding pipe including the bedding. It is properly compacted and placed such that there is complete contact between the pipe and the soil. The final backfill (or the trench backfill) consists of disturbed or remolded native soil dumped and normally compacted above the pipe backfill (Chua and Lytton, 1987).

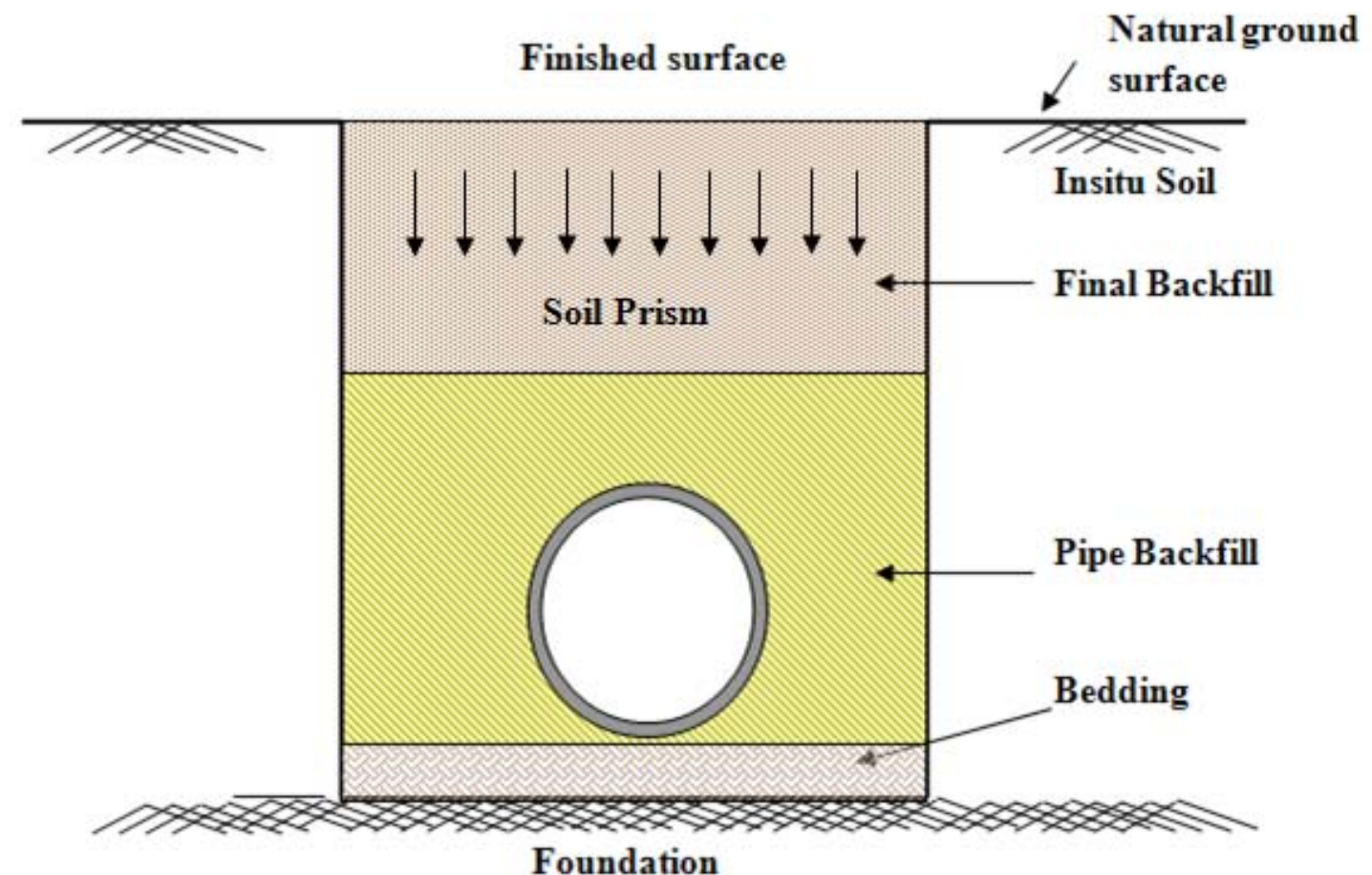

Figure 1.2: Trench geometry of a buried pipe.

These analyses provide information regarding the applicability of flexible or rigid pipe under various fill depths and trench widths. This information is vital from an economic point of view and provides enormous cost- cutting benefits. 


\section{Chapter 2: OVERVIEW OF BURIED PIPE DESIGN}

\subsection{Introduction}

In the last few decades the availability of different types of pipe materials has increased with the emergence of material technology. The concrete pipe industry dominated the early half of the $19^{\text {th }}$ century as it was considered to be the only material which could provide great strength and long-term serviceability (Jeyapalan, 1990). However, in the last half century corrugated steel pipes were followed by the plastic pipe materials to offer stiff competition to the concrete and clay pipe industry. It was often believed that a thicker pipe can resist loads in a more efficient way than a thinner pipe, which may not be always true. When compared to a rigid pipe, flexible pipes deflect more under a given load. Less bending stresses develop implying that a lower moment of inertia is sufficient. Thus, less geometric stiffness is required to handle the bending stresses which imply that a thinner section is efficient (Gabriel, 1990). Significant effort has been put into developing numerous analytical, numerical and experimental procedures which have helped improve the design of buried pipes. Recent studies performed to evaluate the performance of buried pipes are described in the following section.

\subsection{Recent Studies}

The structural performance of high density polyethylene pipes with corrugated profiles have been studied at West Virginia University (Gondle and Siriwardane, 2008; Mada, 2005). Experimental as well as numerical analysis have been performed on these pipes. Controlled Low Strength Material (CLSM) was used as pipe backfill in these two separate studies. Under field and laboratory conditions the performance of single-wall corrugated HDPE pipes was studied by Mada (2005). The performance of single-wall corrugated pipes under varying trench widths and HS-20 loads were analyzed using finite element models. The results from these analyses matched well when compared with the results obtained from laboratory experiments. Also, the influence 
of interface elements was investigated. It has been reported that the interface elements which were placed between the backfill and the insitu soil increased the pipe deflections. From the finite element analyses it was observed that for a backfill height of 50 feet $(15 \mathrm{~m})$ and a trench width ratio as low of 1.5, a pipe can be installed without failure (Mada, 2005).

Two dimensional creep (visco-elastic) analyses of single and double-wall corrugated HDPE pipes were performed using FEM models by Gondle and Siriwardane (2008). The long term performance of these pipes has been analyzed under similar boundary and loading conditions as in the research work done by Mada (2005). The numerical problems persistent in the formulation of pipe models using beam and plane strain elements under confined and unconfined conditions have also been investigated. It was concluded that the beam elements were appropriate to use in the unconfined conditions for geometrical modeling. Results of the static analyses obtained by using the long-term (50 years) pipe elastic modulus, as proposed by American Association of State Highway and Transportation Officials, AASHTO M 294 gave good matches when compared with the results from the transient analyses. Vertical pipe deflections beyond the first year of installation were less when compared to the deflections in the first year of installation. Also, the rate of creep for double-wall corrugated pipes was higher than the single-wall corrugated pipes.

Experimental and numerical techniques were applied to study the correlation between applied load and the resulting deflections of a buried PVC pipe (Cho and Vipulanandan, 2005). The pipe was backfilled with CLSM in a soil box corresponding to a trench condition. A surface pressure on the top of the soil varying from 25 psi to 112 psi was applied in an incremental manner. Due to the presence of side wall friction and a stiff backfill, little variation in the vertical pressure at the crown and the invert of the pipe was observed. Soil-pipe interaction was analyzed with the help of a finite element program. The results indicated that an inverse relation existed between the elastic modulus of CLSM and the vertical deflection of the pipe. The numerical analyses overestimated the short term vertical deflections and underestimated the long term deflections. After a time period of sixty days it was observed that the vertical stresses ceased to change. The effect of soil parameters such as interface friction angle and elastic modulus on the vertical deflection of the pipe was also investigated(Cho and Vipulanandan, 2005). 
A full-scale study of the field performance of large diameter thermoplastic pipes was done by the Ohio Research Institute for Transportation and the Environment (ORITE). The field tests began in the summer of 1999 and lasted for three years (Sargand and Masada, 2007). The main purpose of this study were to determine the long-term creep behavior of HDPE, PVC pipes under deep fill heights and also provide the data which could be used in developing cost effective designs and installation practices. The study revealed that vertical pipe deflections in a HDPE pipe were more when compared to the PVC pipes under similar loading and boundary conditions (Sargand and Masada, 2007).. Two stage regression analyses were performed to explain the long-term creep behavior of thermoplastic pipes buried under deep cover. These analyses were also used to determine the parameters which could influence the short-term and long-term deflections (Sargand and Masada, 2007).

Crosby (2003) has performed finite element analyses on small diameter fiber reinforced and steel reinforced concrete pipes. The main purpose of the study was to analyze the behavior and efficiency of the test setup for different boundary conditions. With the help of finite element programs, the boundary conditions which were stimulated by the applied distributed load were estimated. Some of the observations of the finite element analyses were that the concentration of stresses varied with the degree of compaction of the soil, which had an adverse impact on the structural behavior of the pipe (Crosby, 2003).

A three year field monitoring of two concrete pipe sections were performed in the city of Ottawa, Canada to understand the performance of the pipes and also to authenticate the competence of the standard installations methods (Smeltzer and Daigle, 2005). An attempt was made to provide a cost effective alternative solution to the current design approach of Standard Installation Direct Design (SIDD). In this study, Type 2 and Type 3 of the standard installation methods were demonstrated. Strain gauges which were preinstalled on the reinforcing steel of the pipe during the manufacturing process were used to determine the stresses and thrust acting on the pipe. Soil-pipe interaction was estimated with the use of pressure cells. The measured values of pressures and moments acting on the pipe showed good correlation with the values obtained through the SIDD theory, thereby revealing the competence of the design method. 
Kang et al (2008) studied the phenomena of soil-structure interaction of deeply buried corrugated steel pipes under embankment conditions. The effect of the degree of compaction of soil surrounding the pipe and interface conditions were analyzed through finite element analyses. The data obtained from the finite element analyses were used to derive equations which could predict parameters such as arching factors, pipe deflections, and the maximum stresses generated in the pipe wall due to the overburden load, among others. After a series of trials it was observed that the vertical and horizontal boundaries of an embankment need not extend beyond three times the pipe diameter (Kang et al, 2008). The results obtained from the analyses performed using ABAQUS were compared with those obtained from MSC/NASTRAN 89 and CANDE to verify the legitimacy of the modeling techniques used to design the soil-structure interaction problem. The applicability of the derived equations was investigated by comparing them with the equations already available. A pipe-spring model was also used to assess the buckling strength of the pipe. This research study revealed that the interface elements had a significant effect on the vertical arching factor of the flexible pipe installed in an embankment. The results obtained from the pipe-spring model matched well with those obtained through AISI procedures(Kang et al, 2008).

Several other major studies on the performance of buried pipes have been reported in the literature (Moore and Brachman, 1994; Moore, 1995; Zhang and Moore, 1998; Brachman et al, 2000; McGrath, 1993). These are not reviewed in detail in this report. However, several technical publications provide an excellent review of the past research work on buried pipes (Sargand et al, 1993; Sargand et al, 1998; Buczala and Cassady, 1990).

\subsection{Factors influencing pipe performance}

The factors influencing the performance of a pipe are:

- $\quad$ overburden soil load

- $\quad$ pipe stiffness

- passive resistance of the soil at the sides of the pipe 
- time-consolidation characteristics of soil and

- the degree of bottom support of the pipe

These parameters play a pivotal role in maintaining the structural integrity of the buried pipe (Schrock, 1990). Pipe geometry, load, and resistance offered by the pipe are important parameters which have an impact on the service life of pipes. The geometrical aspects of the pipe such as size, rise, diameter, and slope are also to be considered (Hadipriono et al, 1988). Soil properties such as density and stiffness also have an significant impact on the long-term performance of the pipe (Schrock, 1990). The phenomenon of soil arching is triggered by the creep behavior of soil and pipe, thus requiring special consideration to these factors in the evaluation of the long term performance of the pipe (Petroff, 1990).

\subsection{Design characteristics of buried pipe}

Corrugated steel and plastic pipes make up most of the flexible pipe industry. By proper design of flexible pipes, different forms of failure can be avoided. The following different modes of failure have been reported in the literature (Jeyapalan, 1990):

- $\quad$ Degradation of materials

- $\quad$ Disjointing of seams due to excessive ring compression forces

- $\quad$ Crushing of walls due to disproportionate stresses

- $\quad$ Buckling due to excessive external pressures or internal vacuum

- $\quad$ Excessive deflection leading to leaky joints

- $\quad$ Excessive flexural and compressive or tensile strains leading to yield

Rigid pipes are designed to avoid failure in flexural tension. To avoid failure of a rigid pipe, the total actual load acting on the pipe must be less than the load carrying capability of the 
pipe in the installed condition. Under a given soil load rigid pipes undergo lesser deformations when compared to flexible pipes. Behavior of a pipe depends on the comparative stiffness between soil and the pipe. The flexibility existing between the pipe and soil is an important parameter which determines the load imposed on the pipe. In a trench, load is spread uniformly over the pipe and soil when the stiffness of soil and pipe are equal. In the case of a flexible pipe installed in a trench, the load at the pipe crown is smaller than that corresponding to a rigid pipe. This is due to the relatively low stiffness of the pipe when compared to the soil surrounding it. Pipe deflections and the internal shear resistance play a significant role in the reduction of load acting on the pipe. A vertical displacement of the pipe occurs which accommodates the horizontal deflection of the pipe. Simultaneously, the stiffness of the surrounding soil resists the downward displacement of the pipe. Rigid pipes which are stiffer than the surrounding soil attract more loads. This is due to the response of shearing stresses which transmit the load from the column of soil above the side fill to the prism of soil directly above the pipe (Petroff, 1990). A combination of the above processes and creep behavior of pipe materials makes it difficult to understand the behavior of a soil-pipe system. Thus, the development of rational methods is required to improve the understanding of buried pipe performance.

\subsection{Loads}

The evaluation of the loads acting on the pipe is the first major step in the analysis and structural design of a pipe. The two principal types of loads acting on the pipe are (ADS, 2009):

- Dead loads - these consist of the self-weight of the embankment or the trench backfill materials, and the superimposed stationary uniform or concentrated loads acting at the ground surface; and

- Live loads - these consists of moving loads, loads due to impact from vehicular traffic such as trucks, railways or airplanes. 


\subsubsection{Dead Loads}

The maximum dead load reaching the pipe crown is the load imposed by the complete soil prism over the pipe (NCSPA, 2008) as illustrated in Figure 1.2. In almost all the cases the soil prism load is the only dead load that is considered in the structural design of the pipe (ADS, 2009). Apart from this, loads due to high groundwater, surcharges, and foundations also need to be considered, when applicable (ADS, 2009). The soil column load method and the soil arch load method are two primary techniques employed to determine the magnitude of soil loads (Hancor, 2003). Brief descriptions of these techniques are given in the following sections.

\subsubsection{Soil column load method}

The weight of the soil prism at the level of the pipe crown is referred to as the soil column load $\left(\mathrm{W}_{\mathrm{c}}\right)$. Soil column load is the basis for the development of deflection equations through empirical relationships. Soil columns adjacent to the final backfill directly above the pipe provide additional support. Thus, the actual load coming on the pipe is much less than the calculated soil column loads (Hancor, 2003). The magnitude of soil column load can be derived by using the equation given below (Hancor, 2003):

$$
\mathrm{W}_{\mathrm{C}}=\frac{\mathrm{H}^{*} \gamma_{\mathrm{s}} * \mathrm{O} . \mathrm{D}}{144}
$$

where:

$\mathrm{W}_{\mathrm{c}}=$ soil column load in lbs/ linear inch of pipe

$\mathrm{H}=$ burial depth in feet

$\gamma_{\mathrm{s}}=$ density of soil in pcf

O.D = outside diameter of the pipe in inches. 


\subsubsection{Soil arch load method}

In the soil arch load method, a vertical arching factor is employed which serves as a load reduction factor. The vertical arching factor considers the load reduction effects due to the support provided by the adjacent soil columns to the final backfill directly above the pipe. The soil arch load ( $\left.\mathrm{W}_{\mathrm{ac}}\right)$ more closely represents the actual load experienced by a pipe in real world situations. Soil arch load can be calculated as:

$\mathrm{W}_{\mathrm{ac}}=\mathrm{P}_{\mathrm{sp}} * \mathrm{VAF}$

Here, Psp is the geostatic load and VAF is the vertical arching factor, which are defined below. The geostatic load, $\mathrm{P}_{\mathrm{sp}}$, is the sum of the load exerted by the soil column at the pipe's crown and a small triangular load which extend beyond the outside diameter of the pipe. Geostatic load and the vertical arching factor can be calculated using the following equations (Hancor, 2003):

$\mathrm{P}_{\mathrm{sp}}=\frac{\left(\gamma_{\mathrm{s}}\right)\left(\mathrm{H}+\frac{0.11 \mathrm{O} . \mathrm{D}}{12}\right)}{144}$

Where:

$\mathrm{P}_{\mathrm{sp}}=$ geostatic load in psi

$\mathrm{H}=$ burial depth in feet

$\gamma_{\mathrm{s}}=$ unit weight of soil in pcf

$\mathrm{OD}=$ outside diameter of the pipe in inches

The vertical arching factor, VAF is given below.

$\mathrm{VAF}=0.76-0.71\left[\frac{\mathrm{S}_{\mathrm{h}}-1.17}{\mathrm{~S}_{\mathrm{h}}+2.92}\right]$

Where:

$\mathrm{VAF}=$ vertical arching factor 
$\mathrm{S}_{\mathrm{h}} \quad=$ hoop stiffness factor;

$$
=\left[\frac{\varphi_{\mathrm{S}} \mathrm{M}_{\mathrm{S}} \mathrm{R}}{\mathrm{E} * \mathrm{~A}}\right]
$$

$\mathrm{M}_{\mathrm{S}}$ = secant constrained soil modulus in psi

$\mathrm{R}=$ effective radius of pipe in inches

$\mathrm{E} \quad=$ modulus of pipe in psi

$\mathrm{A}=$ sectional area in in. ${ }^{2} / \mathrm{in}$.

\subsubsection{Live loads}

The magnitude and position of live loads vary during the lifetime of a buried pipe. The primary contributors to live loads such as trucks, railways, and aircrafts are given importance in the structural design of the buried pipes (ADS, 2009). The load carried by each wheel set or tire area of design truck configurations are shown in Figure 2.1 and Table 2.1(ADS, 2009). Previously, H-20 or HS-20 with a 32,000 pound axle loads in were used by AASHTO as design loads (ACPA, 2009). Currently, H-25 or HS-25 configurations are being used. The load magnitudes for HS-25 are $25 \%$ more than the HS-20 loads (Hancor, 2003). Live load data for HS-25 truck configuration (AASHTO, 2007; ADS, 2009) is presented in Table 2.2, which also lists the distribution widths of live loads with respect to H-25 or HS-25 load. According to the AASHTO, the distribution width is based on the assumption that the pipe is installed perpendicular to the direction of traffic (Hancor, 2003). 

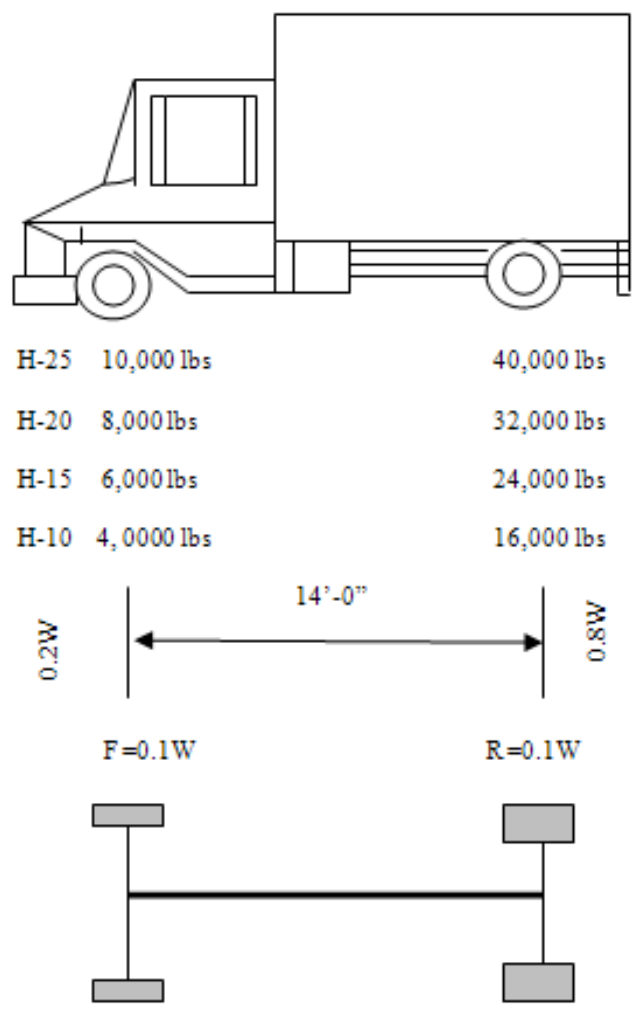

$\mathrm{F}=0.1 \mathrm{~W}$

(a) AASHTO H-Load
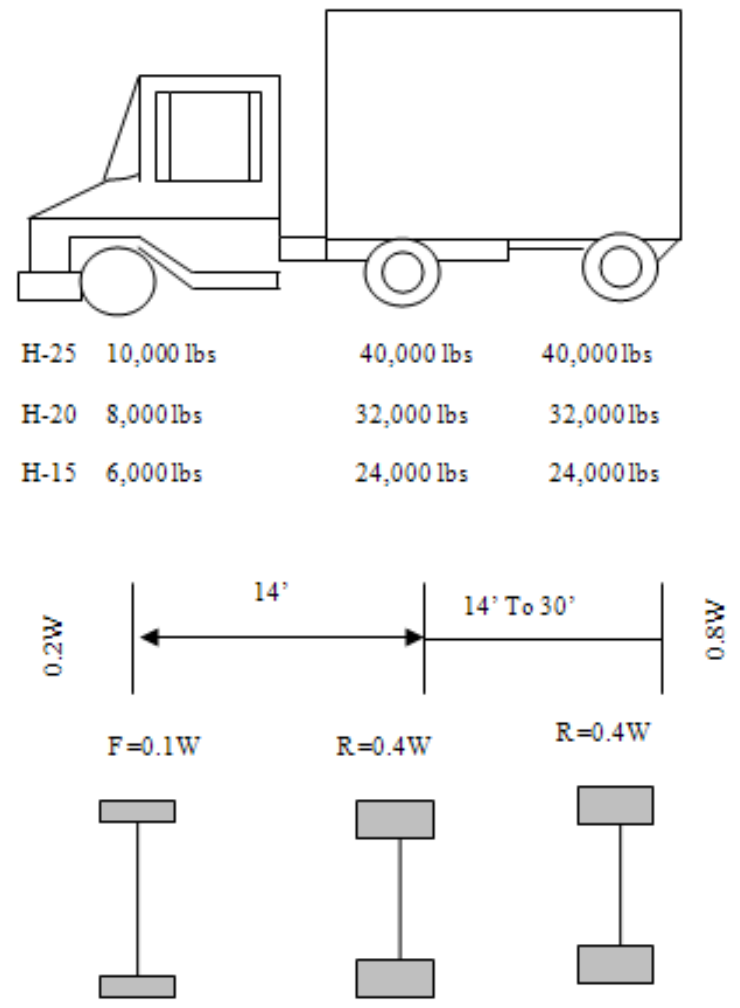

$\mathrm{R}=0.4 \mathrm{~W}$

$\mathrm{R}=0.4 \mathrm{~W}$

$\mathrm{R}=0.1 \mathrm{~W}$
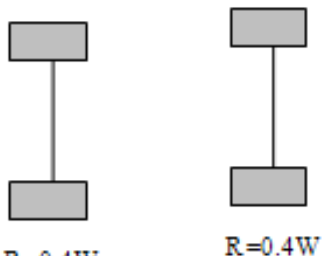

$\mathrm{R}=0.4 \mathrm{~W}$

$\mathrm{R}=0.4 \mathrm{~W}$

Figure 2.1: AASHTO Highway Loads (AASHTO, 2007; ADS,2009).

Note: $\mathrm{W}=$ Total weight of the truck and load 
Table 2.1: AASHTO Highway Loads Carried by Wheel Set (ADS,2009)

\begin{tabular}{|c|c|c|c|c|}
\hline Variables & $\begin{array}{c}\text { H-10 } \\
\mathbf{l b s}(\mathbf{k N})\end{array}$ & $\begin{array}{c}\text { H-15 or HS-15 } \\
\text { lbs }(\mathbf{k N})\end{array}$ & $\begin{array}{c}\text { H-20 or HS-20 } \\
\text { lbs }(\mathbf{k N})\end{array}$ & $\begin{array}{c}\text { H-25 or HS-25 } \\
\text { lbs (kN) }\end{array}$ \\
\hline \multirow{2}{*}{$\mathbf{W}$} & 20,000 & 30,000 & 40,000 & 50,000 \\
& $(89.0)$ & $(133.4)$ & $(178.0)$ & $(222.4)$ \\
\hline \multirow{2}{*}{$\mathbf{F}$} & 2,000 & 3,000 & 4,000 & 5,000 \\
& $(8.9)$ & $(13.3)$ & $(17.8)$ & $(22.4)$ \\
\hline \multirow{2}{*}{$\mathbf{R}$} & 8,000 & 12,000 & 16,000 & 20,000 \\
& $(35.6)$ & $(53.4)$ & $(71.2)$ & $(89.0)$ \\
\hline \multirow{2}{*}{$\mathbf{R}_{\text {AXEL }}$} & 16,000 & 24,000 & 32,000 & 40,000 \\
& $(71.1)$ & $(106.7)$ & $(142.3)$ & $(177.9)$ \\
\hline
\end{tabular}

Note: "F” and "R" are represented in Figure 2.1. $\mathrm{R}_{\mathrm{AXEL}}$ represents the truck’s axel load. 
Table 2.2: Live Load Data for HS-25 and Cooper E-80 (ADS,2009)

\begin{tabular}{|c|c|c|c|}
\hline \multirow[b]{2}{*}{$\begin{array}{l}\text { Cover } \\
\text { ft.(m) }\end{array}$} & \multicolumn{2}{|c|}{$\begin{array}{c}\text { AASHTO } \\
\text { H-25 or HS-25 }\end{array}$} & \multirow{2}{*}{\begin{tabular}{|c|} 
Cooper \\
E-80 \\
Live Load Transferred \\
to Pipe \\
psi(N/mm $\left.{ }^{2}\right)$
\end{tabular}} \\
\hline & $\begin{array}{c}\text { Live Load Transferred } \\
\text { to Pipe } \\
\text { psi }\left(\mathbf{N} / \mathbf{m m}^{2}\right)\end{array}$ & $\begin{array}{l}\text { Live Load Distribution } \\
\text { Width, } \mathrm{L}_{\mathrm{w}} \\
\text { in.(mm) }\end{array}$ & \\
\hline $1(0.3)$ & $15.63(0.108)$ & $31.00(787)$ & $\mathrm{N} / \mathrm{R}$ \\
\hline $2(0.6)$ & $6.95(0.048)$ & $52.00(1,321)$ & $26.39(0.1824)$ \\
\hline $3(0.9)$ & $5.21(0.036)$ & $73.00(1,854)$ & 23.61(0.1632) \\
\hline $4(1.2)$ & $3.48(0.024)$ & $94.00(2,388)$ & $18.40(0.1272)$ \\
\hline $5(1.5)$ & $2.18(0.015)$ & $115.00(2,921)$ & $16.67(0.1152)$ \\
\hline $6(1.8)$ & $1.74(0.012)$ & $136.00(3,454)$ & $15.63(0.1080)$ \\
\hline $7(2.1)$ & $1.53(0.011)$ & $157.00(3,988)$ & $12.15(0.0840)$ \\
\hline $8(2.4)$ & $0.86(0.006)$ & $178.00(4,521)$ & $11.11(0.0768)$ \\
\hline $10(3.0)$ & Negligible & N/A & $7.64(0.0528)$ \\
\hline $12(3.6)$ & Negligible & N/A & $5.56(0.0384)$ \\
\hline $14(4.3)$ & Negligible & N/A & $4.17(0.0288)$ \\
\hline $16(4.9)$ & Negligible & N/A & $3.47(0.0240)$ \\
\hline $18(5.5)$ & Negligible & N/A & $2.78(0.0192)$ \\
\hline $20(6.1)$ & Negligible & N/A & $2.08(0.0144)$ \\
\hline $22(6.7)$ & Negligible & N/A & $1.91(0.0132)$ \\
\hline $24(7.3)$ & Negligible & N/A & $1.74(0.0120)$ \\
\hline $26(7.9)$ & Negligible & N/A & $1.39(0.0096)$ \\
\hline $28(8.5)$ & Negligible & N/A & $1.04(0.0072)$ \\
\hline $30(9.1)$ & Negligible & N/A & $0.69(0.0048)$ \\
\hline $35(10.7)$ & Negligible & N/A & negligible \\
\hline
\end{tabular}

Notes: Includes impact where required: N/R indicates that the cover height is not recommended; N/A indicates that the information is not applicable. 


\subsection{Pipe stiffness}

In a trench (Figure 1.2), both the soil and the pipe behave as a composite structure to maintain equilibrium of the superimposed dead load of the trench backfill and live load of the vehicular traffic. When a flexible pipe is installed in a trench, the load is diverted towards the stiffer material around the pipe. In this case, it would be the soil. Though a rigid pipe is much stronger and thicker than the flexible pipe, the components (e.g., steel reinforcement) added to it make it stiffer than the surrounding soil, thus attracting more load.

Pipe stiffness can be defined as the load necessary to cause a unit displacement along the pipe's vertical diameter (Gabriel, 1990). It can be obtained from the parallel plate load test which is described in the subsequent section. Also, pipe stiffness can be obtained through manual calculations as in the case of steel pipes using an equation based on the classical elastic analysis. Pipe stiffness can be defined as follows (Gabriel, 1990):

$$
\begin{gathered}
\text { P.S }=\frac{\mathrm{F}}{\Delta \mathrm{Y}} \quad \text { (Plate load test) } \\
P . S=\frac{E^{*} I}{0.149 * r^{3}} \quad \text { (From Classical elastic theory) }
\end{gathered}
$$

Where:

P.S is the pipe stiffness (psi)

$\mathrm{F}$ is the force applied on the end of the vertical diameter (lb/in)

$\Delta \mathrm{Y}$ is the deformation of the vertical diameter (in)

$\mathrm{E}$ is the young's modulus of the pipe (psi)

I is the moment of inertia of the pipe section (in ${ }^{4} / \mathrm{in}$ )

$r$ is the radius of the pipe (in)

As per ASTM D 2412, percentage deflection of 5\% is used to determine the stiffness of the pipe. Under given surface and soil loads, a conservative allowance for the change in vertical 
deflection is 5\% (Chambers et al, 1980; Katona, 1993), although, a criterion of $7.5 \%$ has been suggested by others (Soleno, 2005).

\subsection{Laboratory determination of pipe stiffness}

Pipe deflections can be calculated from equations or can be measured in the laboratory by conducting simple pipe bending tests like the three edge bearing load test for rigid materials or parallel plate loading test for flexible pipes. The three edge bearing test (ASTM C497) is performed in order to measure the strength of rigid pipes. As per ASTM C 497, "the three edge bearing load test is performed by placing a pipe on a lower beam consisting of two parallel longitudinal strips made of wood or hard rubber”. In the three edges bearing load test, a vertical load is applied through the upper beam extending along the length of the specimen”. A schematic diagram of a three edge bearing test apparatus is shown in Figure 2.2. Each class and size of rigid pipes should attain specific laboratory strength relative to the expected service load condition. The design load (D-load) for a concrete pipe is defined as the three edge bearing load that produces a crack that is 0.01 inches wide. This design load is used to classify reinforced concrete pipes (Crosby, 2003). The three edge bearing strength can be expressed as follows (ACPA, 1974):

T.E.B $=\left[\frac{\mathrm{W}_{\mathrm{L}}+\mathrm{W}_{\mathrm{E}}}{\mathrm{L}_{\mathrm{F}}}\right] * \mathrm{~F} . \mathrm{S}$

where:

T.E.B = three edge bearing load in pounds per linear foot

$\mathrm{W}_{\mathrm{L}}=$ live load in pounds per linear foot

$\mathrm{W}_{\mathrm{F}}=$ earth load in pounds per linear foot

$\mathrm{L}_{\mathrm{F}}=$ load factor

F.S = factor of safety 


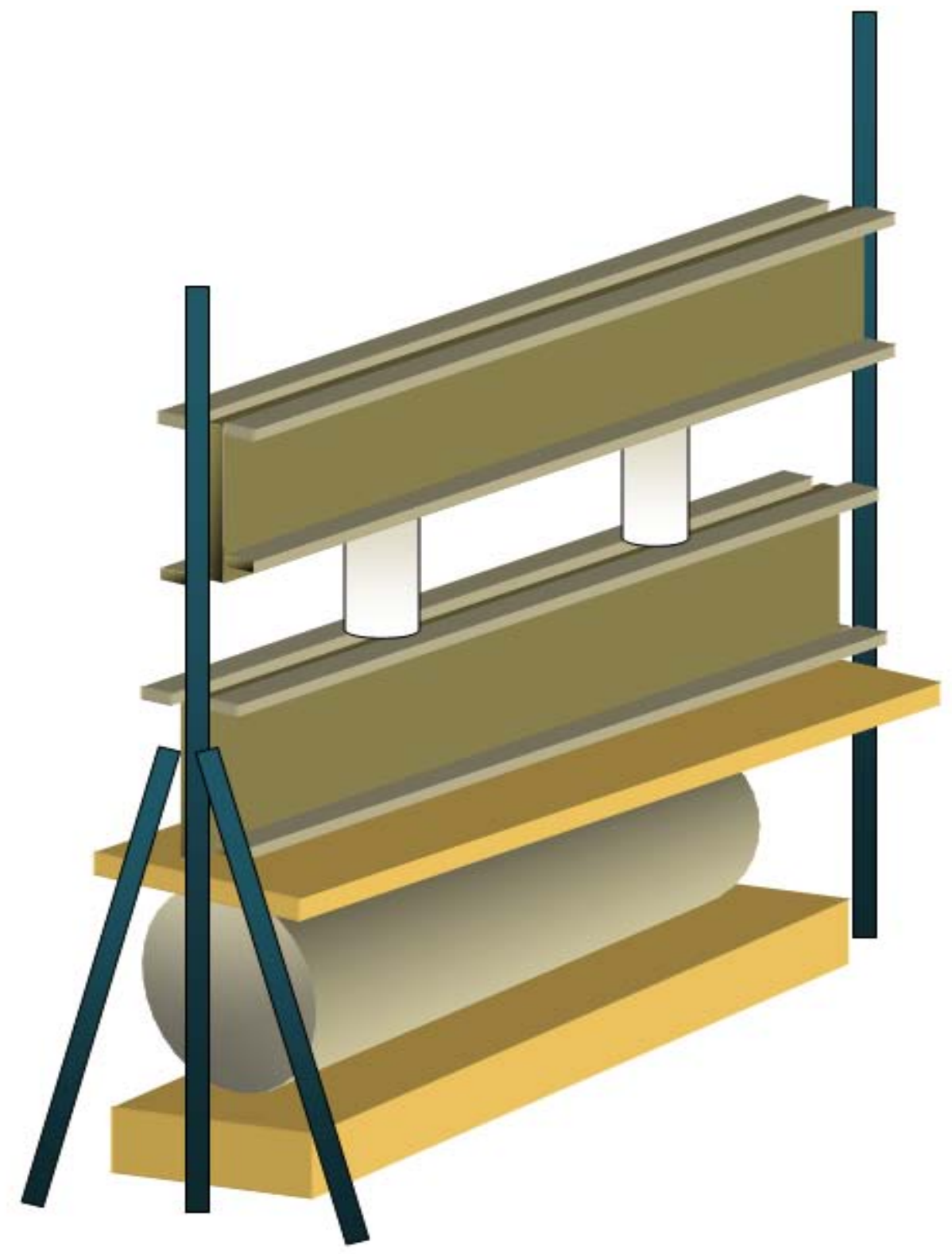

Figure 2.2: Schematic Diagram of a Three Edge Bearing Test Apparatus. 
The parallel plate test (ASTM D 2412, 2000) for flexible pipes is used to determine the pipe stiffness, stiffness factor, and load at specific deflections. This test assures that specified levels of performance are met by the thermoplastic pipes with respect to parameters such as bending stiffness and strength (McGrath and Schafer, 2002). The test procedure consists of subjecting a short length of pipe placed between two stiff surfaces to a load along the vertical diameter of the pipe. The test setup is shown in Figure 2.3. When a load is applied to the pipe as shown in this figure, pipe will deform. As per ASTM D 2412, the test has to be performed at a strain rate of 0.5 inches per minute (Moore, 1994). As described in the literature (ASTM D 2412, 2000), parallel plate loading tests are performed to:

- Determine the stiffness of the pipe. This is a function of the pipe dimensions and the physical properties of the material of which the pipe is made

- Determine the load-deflection characteristics and pipe stiffness which are used in the engineering design

- Compare the characteristics of various plastic pipes

- Study the interrelations of dimensions and deflection properties of plastic pipes and conduits

- Measure the deflection and load-resistance at different loading conditions. 

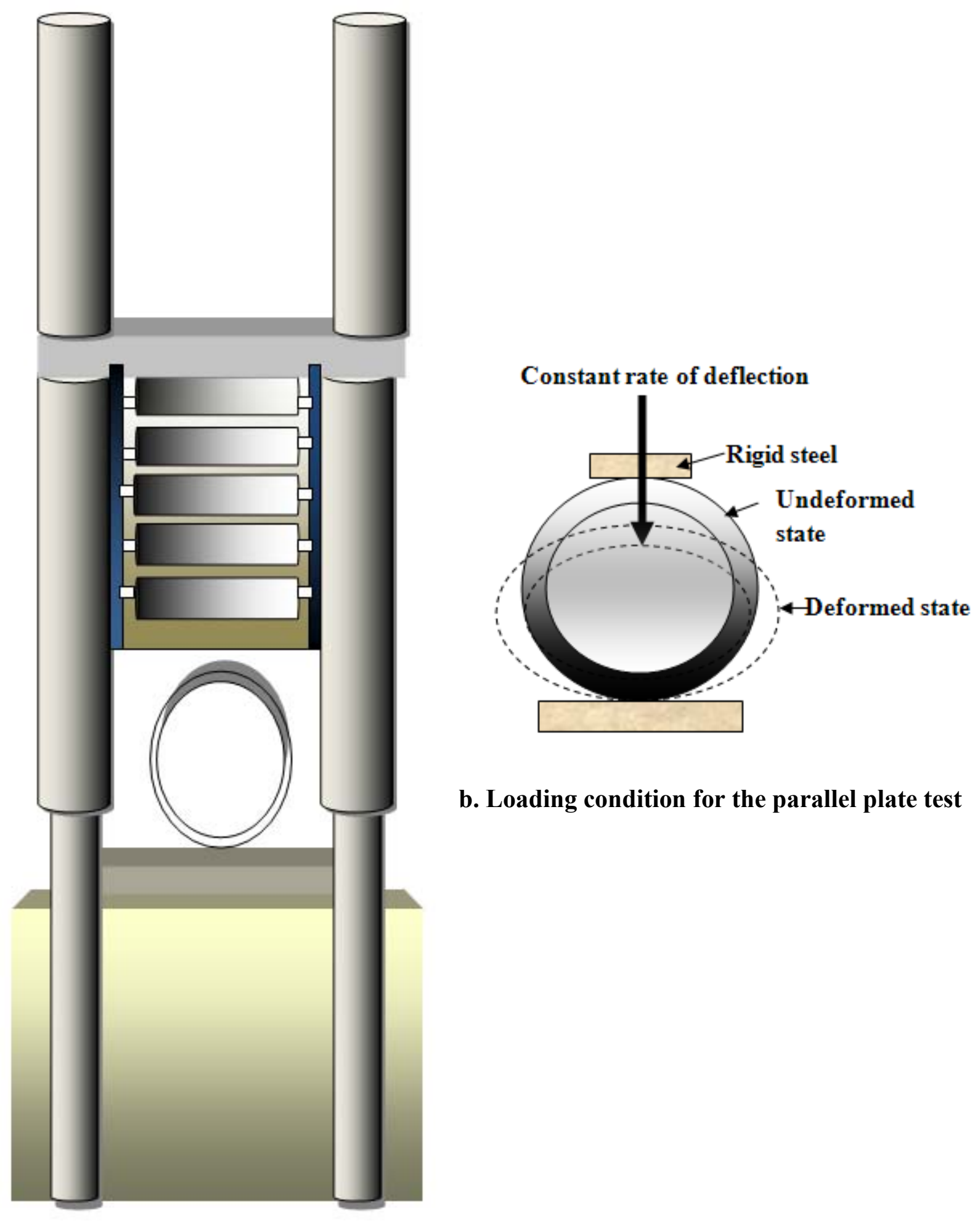

b. Loading condition for the parallel plate test

a. Parallel Plate Testing Machine

Figure 2.3: Parallel Plate Load Test and loading conditions. 


\section{Chapter 3: SOIL PROPERTIES AND THEIR IMPORTANCE IN DESIGN}

\subsection{Soil stiffness}

Limited research had been done to assess the importance of the backfill soil stiffness (Hartley and Duncan, 1987). Soil stiffness is an important parameter in the analysis of buried pipes. Modulus of soil reaction, an empirical parameter was introduced by Spangler (1941) to represent soil stiffness. Modulus of soil reaction not only gave distinct character to soil stiffness, but also was an important parameter in the Iowa formula (Hartley and Duncan, 1987) for determining the pipe deflections. The Iowa formula is the general equation used to calculate pipe deflections due to external loads (Hartley and Duncan, 1987). Figure 3.1 illustrates the assumption used in the development of the Iowa formula. The Iowa formula is as shown below (Spangler, 1941; Hartley and Duncan, 1987):

$$
\Delta x=\frac{\mathrm{D}_{\mathrm{L}} \mathrm{KW}_{\mathrm{C}}}{\frac{\mathrm{EI}}{\mathrm{r}^{3}}+0.061 \mathrm{er}}
$$

Where

$\Delta \mathrm{x}=$ change in the horizontal diameter (in.)

$\mathrm{D}_{\mathrm{L}}=$ deflection lag factor to account for time dependent deflections

$\mathrm{K}=$ bedding constant

$\mathrm{W}_{\mathrm{c}}=$ Marston's load per unit length of the pipe (lb/in.)

$\mathrm{E}=$ modulus of elasticity of the pipe material (psi)

$r=$ mean radius of the pipe (in.)

$\mathrm{I}=$ moment of inertia of the pipe wall per unit length of the pipe (in ${ }^{4} / \mathrm{in}$.)

$\mathrm{e}=$ modulus of passive resistance of the backfill (psi) 


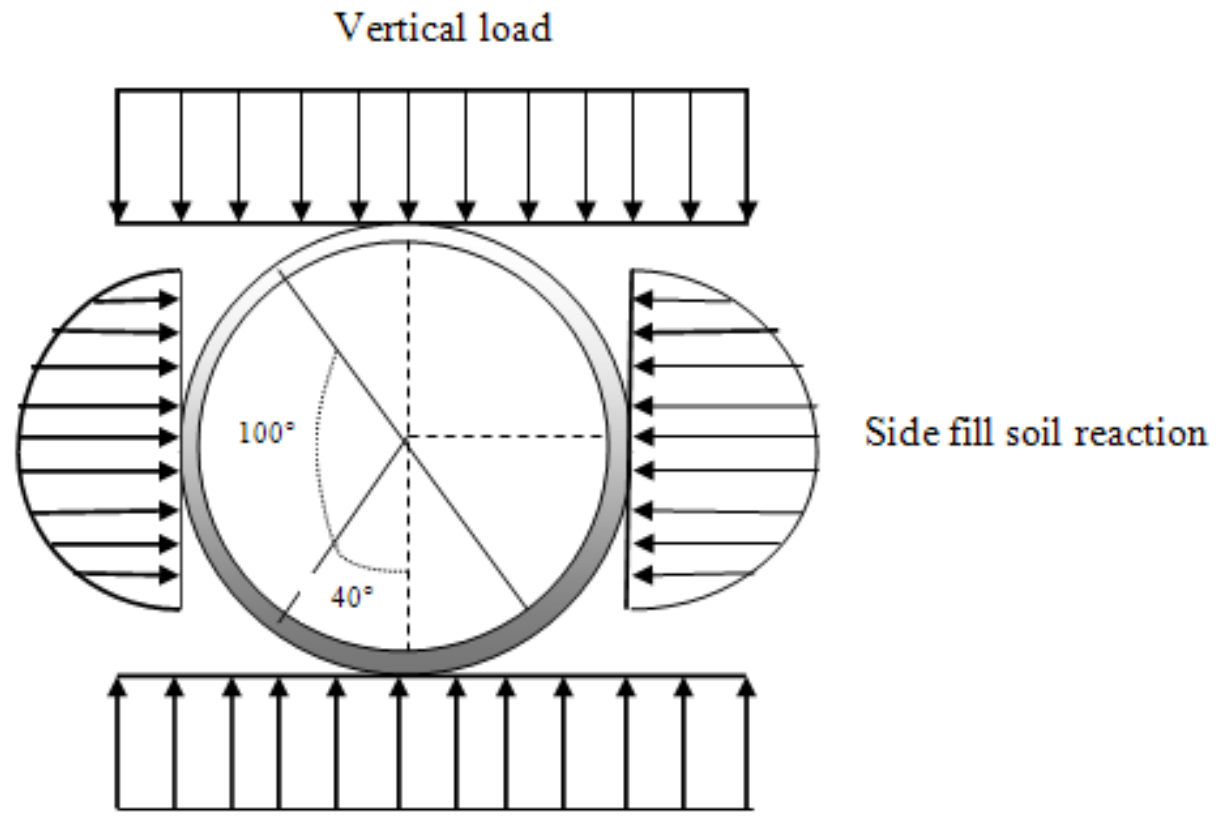

Vertical reaction

Figure 3.1: Spangler's assumptions to develop the Iowa formula (Moser, 2008; Bulson, 1990;Gondle and Siriwardane,2008).

Iowa formula was developed by Spangler (1941) to predict ring deflections of a flexible buried pipe on the basis of a series of laboratory experiments conducted on culverts (Hartley and Duncan, 1987). In the development of the Iowa formula, the following assumptions were made by Spangler (1941):

- Uniform distribution of the vertical load over the pipe's breadth.

- Distribution of the horizontal pressure parabollically over a central arc

- Horizontal peak pressure is directly proportional to the deflection

It was reported by Spangler (1941) ) that the variable “e” (modulus of passive resistance of the backfill, which is defined as the ratio of the horizontal pressure acting on the culvert and the resulting horizontal deflections, remained constant for a given soil. In contrast to this observation, the experiments conducted by Spangler and Watkins in 1958 revealed that the 
modulus of passive resistance was not constant for a given soil. Instead, the product of "e" and "R", the radius of the culvert, was constant. The Iowa formula was modified accordingly by replacing the product of " $\mathrm{e}$ ” and " $\mathrm{R}$ ” with a constant parameter " $\mathrm{E}$ '”. This parameter was called the modulus of soil reaction (Howard, 1977; Brewer, 1990; Bulson, 1990). The modified Iowa formula is given as follows (Spangler and Watkins, 1958; Hartley and Duncan, 1987):

$$
\Delta x=\frac{\mathrm{D}_{\mathrm{L}} \mathrm{KW}_{\mathrm{C}}}{\frac{\mathrm{EI}}{\mathrm{r}^{3}}+0.061 \mathrm{E}^{\prime}}
$$

Where

$\Delta \mathrm{x}=$ change in the horizontal diameter (in.)

$\mathrm{D}_{\mathrm{L}}=$ deflection lag factor to account for time dependent deflections

$\mathrm{K}=$ bedding constant

$\mathrm{W}_{\mathrm{c}}=$ Marston's load per unit length of the pipe (lb/in.)

$\mathrm{E}=$ modulus of elasticity of the pipe material (psi)

$\mathrm{R}=$ mean radius of the pipe (in.)

$\mathrm{I}=$ moment of inertia of the pipe wall per unit length of the pipe (in $4 /$ in.) and

$\mathrm{E}^{\prime}=$ modulus of soil reaction (psi)

The modified Iowa formula proposed by Spangler and Watkins (1958) was also expressed as a function of soil load, pipe stiffness and soil stiffness (Fernando, 1992; Gabriel, 1990) as shown in Equation 3.3.

Culvert deflection $=\frac{\text { Soil load }}{\text { Culvert stiffness }+ \text { Soil stiffness }}$

The modulus of soil reaction (or soil stiffness) varies with the type (or classification) of soil and the degree of consolidation of the backfill soil. From the study performed by Hartley and Duncan (1987), it was reported that the value of E' varied considerably with an increase in 
depth. A relationship between the modulus of soil reaction (E') and the constrained soil modulus $\left(\mathrm{M}_{\mathrm{s}}\right)$ can be expressed as follows (Hartley and Duncan, 1987):

$$
E^{\prime}=k M_{S}
$$

The constant "k" in Equation 3.4 was used by many researchers (Nielson, 1967; Chambers et al, 1980) to relate $\mathrm{M}_{\mathrm{s}}$ and $\mathrm{E}$ '. The value of $\mathrm{k}$ typically ranges between 0.7 and 1.5. For conditions where $\mathrm{E}^{\prime} \approx \mathrm{M}_{\mathrm{s}}$, modulus of soil reaction can be calculated by using the following equation (Hartley and Duncan, 1987):

$$
M_{S}=\frac{E_{S}\left(1-v_{S}\right)}{\left(1+v_{S}\right)\left(1-2 v_{S}\right)}
$$

Where $\mathrm{E}_{\mathrm{S}}$ and $\mathrm{v}_{\mathrm{S}}$ are elastic modulus and Poisson's ratio of the soil, respectively.

\subsection{Backfill materials}

Soil stiffness is a controlling factor in the performance of buried pipes. Soil parameters such as type, density, and moisture content play an important role in deciding the configuration of the trench (Mada, 2005). Installation practices, choice of backfill material, and environmental conditions have influence on the long-term serviceability of buried pipes. It is important to select proper backfill materials that are strong enough to resist pipe deformations (Gondle and Siriwardane, 2008). Table 3.1 shows various classes and types of soil materials used as backfill.

Specifications for backfill materials used in the installation of pipes are indicated in Section 18 of AASHTO and ASTM C 1479. According to these specifications, granular materials used as backfill should not contain debris, organic matter, and frozen material with diameter greater than half the thickness of compacted layers being placed. AASHTO T 99 (2009) specifies that granular soil should be compacted to a minimum of $90 \%$ in the installation of 
flexible pipes. For rigid pipes, the degree of compaction required for backfill soil is attained by specifying standard proctor density (STP). As per ASTM D 2321 specification, soil types that can be used as bedding and backfill material are classified into four classes (I, II, III and IV). Granular soils and soils with no plasticity are grouped under classes I and II; whereas fine grained soils with plasticity are grouped under classes III and IV (Amarasiri, 2000). The typical ranges of modulus of soil reaction as per American Society for Testing Materials (ASTM) are presented in Table 3.2. Modulus of soil reaction values available in the literature are presented in Table 3.3. In this study, CLSM and granular stone have been used as pipe backfill. A brief discussion of these backfill materials is presented in the following sections. 
Table 3.1: Class and Type of Soil used for Backfill Material

(ASTM D2321, 2000; Soleno, 2005; Mada, 2005)

\begin{tabular}{|c|c|c|}
\hline Class & Туре & Backfill description \\
\hline \multirow{2}{*}{$\begin{array}{l}1 \mathrm{~A}^{*} \\
1 \mathrm{~B}^{*}\end{array}$} & \multirow[b]{2}{*}{--} & $\begin{array}{l}\text { Granular material: angular crushed stone or rock, crushed gravel, crushed slag, } \\
\text { large voids, } 6 \text { to } 40 \mathrm{~mm} \text { ( } 1 / 4 \text { to } 1 \frac{11 / 2 \text { inches }) \text { with little or no fines. }}{}\end{array}$ \\
\hline & & $\begin{array}{l}\text { Angular crushed stone or other class 1A material with or without other regional } \\
\text { components such ascoral, ash, crushed stone, shell and stone/sand mixture, with } \\
\text { little or no fines. }\end{array}$ \\
\hline \multirow{4}{*}{$\mathrm{II} *$} & GW & $\begin{array}{l}\left.\text { Well-graded gravel of } 40 \mathrm{~mm} \text { ( } 1 \frac{1 / 2}{2} \text { inches }\right) \text { maximum and mixture of sand and } \\
\text { gravel, little or no fines. } 50 \% \text { or more of gross retained by \#4 sifters. More than } \\
95 \% \text { retained by \#200 sifters. Clean. }\end{array}$ \\
\hline & GP & $\begin{array}{l}\text { Poorly graded gravel, gravel/sand mixtures, little or no fines. } 50 \% \text { or more of } \\
\text { gross retained by \#4 sifters. More than } 95 \% \text { retained by \#200 sifters. Clean. }\end{array}$ \\
\hline & SW & $\begin{array}{l}\text { Well-graded sands, gravel sand; little or no fines. } 50 \% \text { or more of gross retained } \\
\text { by \#4 sifters. More than } 95 \% \text { retained by \#200 sifters. Clean. }\end{array}$ \\
\hline & SP & $\begin{array}{l}\text { Poorly graded gravel, gravelly sands, little or no fines. } 50 \% \text { or more of gross } \\
\text { retained by \#4 sifters. More than } 95 \% \text { retained by \#200 sifters. Clean. }\end{array}$ \\
\hline \multirow{4}{*}{ III* } & GM & $\begin{array}{l}\text { Silty gravels, gravel/sand/slit mixtures More than } 50 \% \text { passes through \#4 sifters. } \\
\text { More than } 50 \% \text { retained by \#200 sifters. }\end{array}$ \\
\hline & GC & $\begin{array}{l}\text { Clayish sands, gravel/sand/clay mixtures More than } 50 \text { \% passes through \#4 } \\
\text { sifters. More than } 50 \% \text { retained by \#200 sifters. }\end{array}$ \\
\hline & SM & $\begin{array}{l}\text { Silty sands, sand/slit mixtures. More than } 50 \% \text { passes through \#4 sifters. More } \\
\text { than } 50 \% \text { retained by \#200 sifters. }\end{array}$ \\
\hline & $\mathrm{SC}$ & $\begin{array}{c}\text { Clayish sands, sand/clay mixtures More than } 50 \% \text { passes through \#4 sifters. } \\
\text { More than } 50 \% \text { retained by \#200 sifters. }\end{array}$ \\
\hline \multirow{2}{*}{ IVA*** } & ML & $\begin{array}{c}\text { Inorganic silts and very fine sands, rock flour silty or clayish fine sands, silts with } \\
\text { slight plasticity, sand with average to high flow and liquidity limit. Limit of } 50 \% \\
\text { or less liquid. More than } 50 \% \text { passes through \#200 sifters }\end{array}$ \\
\hline & CL & $\begin{array}{c}\text { Inorganic clays of low to moderate plasticity, gravelly, sandy or silty clays, lean } \\
\text { clays, sand with moderate to high flow and liquidity limit. Limit of } 50 \% \text { or less } \\
\text { liquid. More than } 50 \% \text { passes through \#200 sifters. }\end{array}$ \\
\hline \multirow[t]{2}{*}{ IVB*** } & MH & $\begin{array}{c}\text { Inorganic silts, macaceous or diamaceous fine sandy or silty soils, elastic soils } \\
\text { with moderate to highflow and liquidity limit. Limit of } 50 \% \text { or less liquid. More } \\
\text { than } 50 \% \text { passes through \#200 sifters. }\end{array}$ \\
\hline & $\mathrm{CH}$ & $\begin{array}{l}\text { Inorganic clays of high plasticity with moderate to high flow and liquidity limit. } \\
\text { Limit of } 50 \% \text { or less liquid. More than } 50 \% \text { passes through \#200 sifters. }\end{array}$ \\
\hline \multirow{3}{*}{$\mathrm{V}^{* * * *}$} & OL & $\begin{array}{c}\text { Organic slits and organic silty clays with low plasticity. Limit of } 50 \% \text { or less } \\
\text { liquid. More than } 50 \% \text { passes through \#200 sifters. }\end{array}$ \\
\hline & $\mathrm{OH}$ & $\begin{array}{l}\text { Organic clays of moderate to high plasticity, organic silts. Limit of } 50 \% \text { or less } \\
\text { liquid. More than } 50 \% \text { passes through \#200 sifters. }\end{array}$ \\
\hline & PT & Peat, manure and other highly organic soils. \\
\hline
\end{tabular}

* As described in standard ASTM D 2487, with the exception of Class I materials which are described in the ASTM D 2321 standard.

** According to standard ASTM D 2487, less than 5 \% of soils pass through \#200 sifter. 
*** According to standard ASTM D 2487, 5 to $12 \%$ of soils that pass through \#200 sifter fall within the limits of the classification which is more characteristic of class II than class III. Soils of types MH, ML, CH and CL are not recommended for the bedding, the haunch or the initial backfill.

**** This class includes frozen soil, debris and rocks bigger than 40mm (1 1 1/2 inches) in size. All materials OL, OH and PT are not recommended for the bedding, the haunch or the initial backfill. 
Table 3.2: Modulus of the Soil Reaction $\left(E^{\prime}\right)^{*}$

\begin{tabular}{|c|c|c|c|c|c|c|c|c|}
\hline \multicolumn{9}{|c|}{ Modulus of soil reaction $-\mathbf{E}$} \\
\hline \multicolumn{4}{|c|}{ Pipe Backfill Material } & \multicolumn{5}{|c|}{$\begin{array}{l}\text { E' kPa (psi) } \\
\text { According to the degree of compaction }\end{array}$} \\
\hline \multicolumn{2}{|c|}{$\begin{array}{l}\text { ASTM D2321 } \\
\text { Class Description }\end{array}$} & \multicolumn{2}{|c|}{$\begin{array}{l}\text { ASTM D2487 } \\
\text { Symbol } \\
\text { Description }\end{array}$} & $\begin{array}{l}\text { Min. } \\
\text { Recommended } \\
\text { Proctor }\end{array}$ & Dumped & $\begin{array}{c}\text { Light } \\
<85 \% \\
\text { relative } \\
\text { density } \\
<40 \%\end{array}$ & $\begin{array}{c}\text { Moderate } \\
85 \text { to } 95 \% \\
\text { Relative } \\
\text { density } \\
40 \text { to } 70 \%\end{array}$ & $\begin{array}{c}\text { High } \\
>95 \% \\
\text { Relative } \\
\text { density } \\
>70 \%\end{array}$ \\
\hline $\begin{array}{l}\text { IA } \\
\text { IB }\end{array}$ & $\begin{array}{l}\text { Crushed } \\
\text { gravel, } \\
\text { manufact } \\
\text { ured }\end{array}$ & $\mathrm{S} / \mathrm{O}$ & $\begin{array}{l}\text { Crushed } \\
\text { gravel, } \\
\text { angular } \\
\text { and large }\end{array}$ & Diverse & $\begin{array}{c}1,000 \\
(6,895)\end{array}$ & $\begin{array}{c}3,000 \\
(20,685)\end{array}$ & $\begin{array}{c}3,000 \\
(20,685)\end{array}$ & $\begin{array}{c}3,000 \\
(20,685)\end{array}$ \\
\hline II & $\begin{array}{l}\text { Granular } \\
\text { soils, } \\
\text { clean }\end{array}$ & $\begin{array}{l}\text { GW, } \\
\text { GP, } \\
\text { SW, } \\
\text { SP }\end{array}$ & $\begin{array}{c}\text { Gravel or } \\
\text { sand with } \\
\text { little or } \\
\text { no fine } \\
\text { particles }\end{array}$ & $85 \%$ & $\begin{array}{c}200 \\
(1379)\end{array}$ & $\begin{array}{c}1,000 \\
(6,895)\end{array}$ & $\begin{array}{c}2,000 \\
(13,790)\end{array}$ & $\begin{array}{c}3,000 \\
(20,685)\end{array}$ \\
\hline III & $\begin{array}{l}\text { Granular } \\
\text { soils with } \\
\text { fines }\end{array}$ & $\begin{array}{l}\text { GM, } \\
\text { GP, } \\
\text { SW, } \\
\text { SP }\end{array}$ & $\begin{array}{l}\text { Mixture } \\
\text { of gravel } \\
\text { or sand } \\
\text { with } \\
\text { other } \\
\text { compone } \\
\text { nts }<10 \% \\
\text { fines }\end{array}$ & $90 \%$ & $\begin{array}{l}1,000 \\
(690)\end{array}$ & $\begin{array}{c}400 \\
(2,758)\end{array}$ & $\begin{array}{c}1,000 \\
(6,895)\end{array}$ & $\begin{array}{c}2,000 \\
(13,790)\end{array}$ \\
\hline IVA & $\begin{array}{l}\text { Granular, } \\
\text { fine } \\
\text { inorganic } \\
\text { soils }\end{array}$ & $\begin{array}{l}\text { ML } \\
\text { CL }\end{array}$ & $\begin{array}{l}\text { Cohesive } \\
\text { soil with } \\
\text { little to } \\
\text { moderate } \\
\text { plasticity }\end{array}$ & For all us & $\begin{array}{r}\text { Not R } \\
\text { Data } \\
\text { ge, request }\end{array}$ & $\begin{array}{l}\text { commend } \\
\text { lot availab } \\
\text { APPROVA }\end{array}$ & of a soil expe & \\
\hline IVB & $\begin{array}{l}\text { Granular, } \\
\text { fine } \\
\text { inorganic } \\
\text { soils }\end{array}$ & $\begin{array}{l}\mathrm{MH} \\
\mathrm{CH}\end{array}$ & $\begin{array}{l}\text { Cohesive } \\
\text { soil with } \\
\text { high } \\
\text { plasticity }\end{array}$ & & & & & \\
\hline $\mathrm{V}$ & $\begin{array}{c}\text { Organic } \\
\text { or highly } \\
\text { organic } \\
\text { soils }\end{array}$ & $\begin{array}{l}\text { OL, } \\
\text { OH, } \\
\text { PT }\end{array}$ & -------- & & & & & \\
\hline
\end{tabular}

*Reference :( Soleno, 2005; Gondle and Siriwardane, 2008) 
Table 3.3: Backfill Soil Properties used in Previous Studies

\begin{tabular}{|c|c|c|c|c|}
\hline Author & Type of soil & $\begin{array}{c}\text { Soil } \\
\text { Modulus } \\
\text { (psi) }\end{array}$ & $\begin{array}{c}\text { Poisson's } \\
\text { ratio }\end{array}$ & $\begin{array}{l}\text { Density } \\
\text { (pcf) }\end{array}$ \\
\hline Arockiasamy et al (2006) & SP-SM (95 \% compaction) & 2,000 & -- & -- \\
\hline Dhar and Moore(2002) & (85 \% compacted) & 930 & 0.36 & 101.45 \\
\hline $\begin{array}{c}\text { Shmulevich and Foux } \\
\text { (1986) }\end{array}$ & SP(>95\% compaction) & 2,300 & -- & - \\
\hline Jeyapalan et al (1987) & GW(100\% compaction) & 3,000 & -- & 125 \\
\hline \multirow{4}{*}{ Moore(1995) } & SW(95\% compaction) & $\begin{array}{l}7,690- \\
22,000 \\
\end{array}$ & 0.30 & 140 \\
\hline & SW(85\% compaction) & $4,061-6,820$ & -- & 140 \\
\hline & ML(90\% compaction) & $2,030-2,760$ & -- & 115 \\
\hline & CL(90\% compaction) & $725-1,450$ & & 100 \\
\hline \multirow[t]{2}{*}{ Faragher et al (1998) } & Lightly compacted soil & $\begin{array}{l}2,600- \\
13,600 \\
\end{array}$ & -- & 111 \\
\hline & Gravel & $\begin{array}{l}4,200- \\
21,465 \\
\end{array}$ & -- & 92 \\
\hline \multirow{3}{*}{ Howard (1977) } & Low plasticity clay (CL) & 400 & -- & -- \\
\hline & Low plasticity silt (ML) & 1,000 & -- & -- \\
\hline & Well graded sand (SW) & 2,000 & -- & -- \\
\hline \multirow{3}{*}{$\begin{array}{c}\text { Selig (1988); } \\
\text { Hashash and Selig (1990) }\end{array}$} & Low plasticity clay (CL) & $500-2,200$ & -- & -- \\
\hline & Low plasticity silt (ML) & $\begin{array}{c}1,400- \\
5,800 \\
\end{array}$ & -- & -- \\
\hline & Well graded sand (SW) & $\begin{array}{l}4,060- \\
11,900\end{array}$ & -- & -- \\
\hline \multirow[b]{2}{*}{$\begin{array}{l}\text { Hartley and Duncan (1987); } \\
\text { Goddard (2003) }\end{array}$} & Fine grained soils (CL, ML) & $500-2,600$ & $0.35-0.40$ & $100-150$ \\
\hline & $\begin{array}{l}\text { Coarse grained soils (SP, } \\
\text { SW, GP, GW) }\end{array}$ & $600-3,800$ & $0.30-0.35$ & -- \\
\hline Brachman et al (1996) & Clay & 1,450 & 0.35 & -- \\
\hline $\begin{array}{l}\text { Moore and Brachman } \\
\text { (1994) }\end{array}$ & $\begin{array}{c}\text { Granular Backfill (>95 \% } \\
\text { compacted) }\end{array}$ & 11,600 & 0.30 & 114 \\
\hline Suleiman and Coree (2004) & Silty Sand (SM ) & 1,000 & 0.35 & 120 \\
\hline Brachman et al (2000) & $\begin{array}{c}\text { Granular Backfill (90\% } \\
\text { compacted) }\end{array}$ & 4,350 & 0.30 & 114 \\
\hline
\end{tabular}




\subsubsection{Controlled Low Strength Material (CLSM)}

Controlled low strength material (CLSM) can be defined as a material which possesses a compressive strength less than 1,200 psi at 28 days (Brewer, 1990). CLSM mainly consists of Portland cement, water, and fine aggregate materials such as fly ash (Brewer, 1990). Properties of CLSM are very different from other materials such Portland cement-based concrete. Low compressive strength allows easy removal of CLSM at some later date. A compressive strength of less than 100 psi at 28 days can be obtained by proper mix design of CLSM materials. Careful design of CLSM ensures good flow characteristics. CLSM used as pipe-backfill should have good flow characteristics during placement (Brewer, 1990). CLSM is a good option when it is required to place the backfill in locations which are not easily accessible or where the process of compaction is difficult (Green et al, 1998). Since CLSM does not consolidate with time after its initial subsidence, the stiffness of CLSM does not depend on the depth of cover (Brewer, 1990). Table 3.4 provides the recommended values of soil modulus for CLSM by various researchers.

Table 3.4: Controlled Low Strength Material Properties Available in the Literature

\begin{tabular}{|c|c|}
\hline Author & $\begin{array}{c}\text { Modulus of Soil } \\
\text { Reaction E' } \\
\text { psi (MPa) }\end{array}$ \\
\hline Brewer and Hurd(1993) & $\begin{array}{l}1,000 \text { or greater } \\
(6.89) \text { or greater }\end{array}$ \\
\hline Brewer(1990) & $\begin{array}{c}72-2,043 \\
(0.49-14.08)\end{array}$ \\
\hline Cho and Vipulanandan(2005) & $\begin{array}{l}1,000-27,000 \\
(6.89-186.16)\end{array}$ \\
\hline Webb et al (1998) & $\begin{array}{l}34,000.0 \\
(234.42)\end{array}$ \\
\hline
\end{tabular}


For a given value of E', the pipe deflection can be reduced to almost half when CLSM is used instead of conventional backfills (Brewer, 1990). CLSM can be a good substitute for high quality crushed backfill (Webb et al, 1998).

A material like CLSM can be poured directly into the trench without any compaction effort. It is economical to use CLSM materials because trench widths can be reduced to a large extent (Brewer, 1990). "CLSM is an excellent backfill material for pipe installation because it flows into place around the pipe and provides uniform, continuous support in the bedding, side fill, and the haunch zone" (McGrath and Hoopes,1998). Beside these advantages, there are also some disadvantages associated with the usage of CLSM as stated below (Howard and Hitch, 1998; ADS, 2009):

- Need to anchor lighter weight pipes

- Confinement needed before setting

- Higher strength mixtures may not allow excavation

- Material cost is usually higher

- Displacement of the pipe due to floatation 


\subsubsection{Granular stone (Crushed stone)}

Crushed stones or granular stones are widely used aggregates in highway construction. Crushed stones are manufactured by blasting, drilling, excavating, and crushing the bedrock (Langer, 2006). Due to their angular shape, interlocking between stone particles takes place, resulting in an increase of bond strength. For highway drainage construction, ASTM D 2321 recommends three materials which can be used for bedding, haunching, and initial backfilling. The American Society for Testing Materials (ASTM) recommendations and specifications for crushed stones are shown in Tables 3.5 and 3.6, respectively. Crushed stones yield high densities with a minimum of compaction effort. Other advantages of using crushed stones are as follows (Mallinson, 1988):

- They can be poured directly into the trench; crushed stone will compact to $90 \%$ or more of its maximum density

- The need for the equipment or labor for additional compaction is eliminated

- It is a good drainage material and prevents the problem of clumping since it does not retain water

Modulus of soil reaction for crushed stone available in the literature is presented in Table 3.7. 
Table 3.5: ASTM Specifications for Class I Material used as Pipe Backfill*

\begin{tabular}{|c|c|c|c|c|c|c|c|c|}
\hline \multirow[b]{2}{*}{$\begin{array}{c}\text { Soil } \\
\text { class }\end{array}$} & \multirow[b]{2}{*}{ Type } & \multirow{2}{*}{$\begin{array}{c}\text { Soil } \\
\text { group } \\
\text { symbol } \\
\text { D } 2487\end{array}$} & \multirow[b]{2}{*}{ Description } & \multicolumn{3}{|c|}{$\begin{array}{c}\text { Percentage passing } \\
\text { sieve sizes }\end{array}$} & \multicolumn{2}{|c|}{$\begin{array}{l}\text { Atterberg } \\
\text { Limits }\end{array}$} \\
\hline & & & & $\begin{array}{l}11 / 2 \\
\text { in. } \\
(40 \\
\text { mm) }\end{array}$ & $\begin{array}{l}\text { No. } 4 \\
(4.75 \\
\text { mm) }\end{array}$ & $\begin{array}{c}\text { No.200 } \\
(\mathbf{0 . 0 7 5} \\
\text { mm) }\end{array}$ & $\mathbf{L L}$ & PI \\
\hline I A & $\begin{array}{l}\text { Manufactured } \\
\text { aggregates: } \\
\text { Open - } \\
\text { graded, clean. }\end{array}$ & None & $\begin{array}{l}\text { Angular, } \\
\text { crushed stone } \\
\text { or rock, } \\
\text { crushed } \\
\text { gravel, } \\
\text { broken coral, } \\
\text { crushed slag, } \\
\text { cinder or } \\
\text { shells; large } \\
\text { void contents } \\
\text { contains little } \\
\text { or no fines }\end{array}$ & $\begin{array}{c}100 \\
\%\end{array}$ & $\begin{array}{c}\leq 10 \\
\%\end{array}$ & $<5 \%$ & $\begin{array}{r}\mathrm{Nc} \\
\mathrm{Pla}\end{array}$ & \\
\hline I B & $\begin{array}{c}\text { Manufactured, } \\
\text { processed } \\
\text { aggregates; } \\
\text { dense-graded, } \\
\text { clean. }\end{array}$ & None & $\begin{array}{l}\text { Angular, } \\
\text { crushed stone } \\
\text { (or other } \\
\text { Class IA } \\
\text { materials) } \\
\text { and } \\
\text { stone/sand } \\
\text { mixtures with } \\
\text { gradations } \\
\text { selected to } \\
\text { minimize } \\
\text { migration of } \\
\text { adjacent } \\
\text { soils; } \\
\text { contains little } \\
\text { fines or soils. }\end{array}$ & $\begin{array}{c}100 \\
\%\end{array}$ & $\begin{array}{c}\leq 50 \\
\%\end{array}$ & $<5 \%$ & $\begin{array}{r}\mathrm{Nc} \\
\mathrm{Pla}\end{array}$ & \\
\hline
\end{tabular}

* Reference Amarasiri (2000) 
Table 3.6: ASTM D 2321 Recommendations for Embedment and Backfill Materials of Class I*

\begin{tabular}{|c|c|c|}
\hline $\begin{array}{l}\text { Soil Class (see Table } \\
\text { 3.5) } \\
\end{array}$ & Class I A & Class I B \\
\hline $\begin{array}{l}\text { General } \\
\text { recommendations } \\
\text { and restrictions }\end{array}$ & $\begin{array}{c}\text { Do not use where conditions may cause migrations of fines from } \\
\text { adjacent soil and loss of pipe support. Suitable for use in a drainage } \\
\text { blanket and under drain in rock cuts where adjacent material is suitably } \\
\text { graded. }\end{array}$ & $\begin{array}{l}\text { Process materials as required to obtain gradation } \\
\text { which will minimize migration of adjacent materials. } \\
\text { Suitable for use as drainage blankets and under drain. }\end{array}$ \\
\hline Foundation & $\begin{array}{l}\text { Suitable as foundation and for replacing over excavated and unstable } \\
\text { trench bottom as restricted above. Install and compact in 6-inch } \\
\text { maximum layers }\end{array}$ & $\begin{array}{l}\text { Suitable as foundation and for replacing over } \\
\text { excavated and unstable trench bottom as restricted } \\
\text { above. Install and compact in 6-inch maximum layers }\end{array}$ \\
\hline Bedding & $\begin{array}{l}\text { Suitable as restricted above. Install in 6-inch maximum layers. Level } \\
\text { final grade by hand. Minimum depth } 4 \text { inches }\end{array}$ & $\begin{array}{l}\text { Install and compact in 6- inch maximum layers. } \\
\text { Level final grade by hand. Minimum depth } 4 \text { inches }\end{array}$ \\
\hline Haunching & $\begin{array}{l}\text { Suitable as restricted above. Install in 6-inch maximum layers. Work in } \\
\text { around pipe by hand to provide uniform support. }\end{array}$ & $\begin{array}{l}\text { Install and compact in 6- inch maximum layers. } \\
\text { Work in around pipe by hand to provide uniform } \\
\text { support. }\end{array}$ \\
\hline Initial backfill & $\begin{array}{l}\text { Suitable as restricted above. Install to a minimum of 6- inch above } \\
\text { crown pipe. }\end{array}$ & Install and compact in 6- inch above pipe crown. \\
\hline $\begin{array}{l}\text { Embedment } \\
\text { compaction }^{1}\end{array}$ & $\begin{array}{l}\text { Place and work by hand to ensure all excavated voids and haunch areas } \\
\text { are filled. For high densities use vibratory compactors. }\end{array}$ & $\begin{array}{l}\text { Minimum density } 85 \% \text { std.Proctor }{ }^{2} . \text { Use hand } \\
\text { tampers or vibratory compactors. }\end{array}$ \\
\hline
\end{tabular}
Notes:

${ }^{1}$ When using mechanical compactors avoid contact with the pipe. When compacting over pipe crown maintain a minimum of 6 inch cover when using small mechanical compactors. When using larger compactors, maintain maximum clearance as required by the engineer.

2 The minimum densities given in the table are intended as the compaction requirements for obtaining satisfactory embedment stiffness in most installation conditions.

* Reference Amarasiri (2000) 
Table 3.7: Soil Modulus of Crushed Stone used in Previous Studies

\begin{tabular}{|c|c|}
\hline Author & $\begin{array}{c}\text { Soil Modulus, } \\
\text { psi } \\
\text { (MPa) }\end{array}$ \\
\hline Masada and Sargand(2005) & $\begin{array}{c}3,100-5,000 \\
(21.37-34.47)\end{array}$ \\
\hline Howard (1997) & $\begin{array}{c}3,000 \\
(20.68)\end{array}$ \\
\hline Brachman et al (1996) & 7,250 \\
& $(49.99)$ \\
\hline ASTM D 2487 (2000) & $742-2,228$ \\
& $(5.11-15.36)$ \\
\hline
\end{tabular}

\subsection{Pipe-soil interaction}

The interaction between soil and the pipe generates moment and tangential forces at different locations in the pipe. The distribution of pressure at the pipe-soil interface and the total load transmitted to the pipe are useful parameters in evaluating the soil-pipe interaction (McGrath, 1993) .The interaction between the backfill soil, pipe backfill, and the pipe are important in determining the structural performance of the pipe (Goddard, 2003; Gondle and Siriwardane, 2008). Understanding the character of soil-pipe interaction is necessary for predicting the performance of a buried pipe (Gabriel, 1998; Heger, 1993).

\subsection{Soil arching}

One of the most common phenomenon encountered in buried pipes in the field and laboratory is soil arching. The reduction in load by the formation of an arch through 
soil-pipe interaction can be seen in most of the field situations involving buried pipes (Sargand and Masada, 2000; Petroff, 1990). Granular soils and most fine grained soils having an angle of internal friction greater than zero in their drained state can experience arching. Soil arching is also triggered by soil and pipe materials which possess viscoelastic properties. When a flexible pipe is installed in soil, it experiences lesser load. Soil acts as an arch by distributing the load coming on to the pipe into the soil surrounding the pipe. Thus, the soil carries larger load than the pipe (Moser, 2008). This is known as positive arching and is illustrated in Figure 3.2(a). In the case of a rigid pipe which is stiffer than the surrounding soil, negative arching takes place as shown in Figure 3.2(b). Due to the smaller deformations that occur along the vertical diameter of the pipe, the mobilization of shear resistance of embedding soil doesn't take place. Shearing stresses transmit part of the load carried by the soil above the side fill into the soil column (final backfill) present above the pipe. This leads to an increase in the load transmitted to the pipe (Moser, 2008).

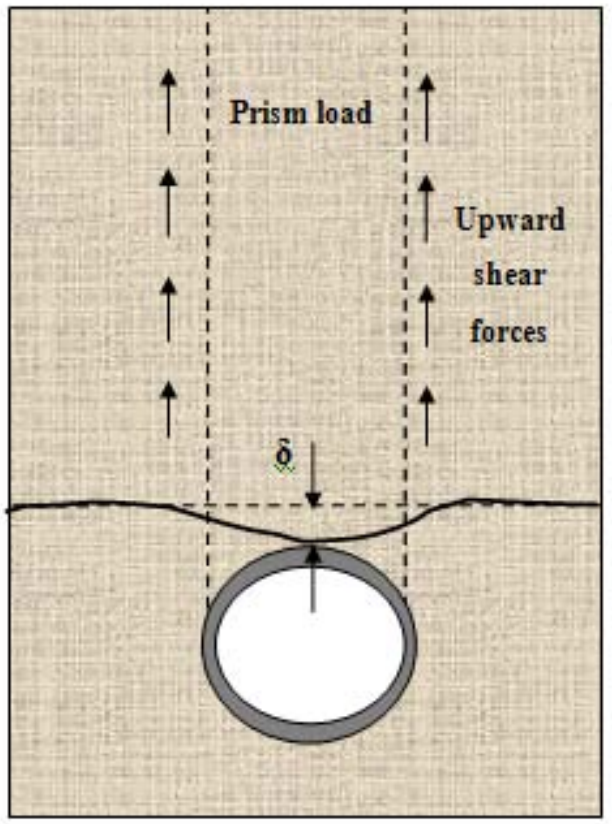

(a) Flexible Pipe

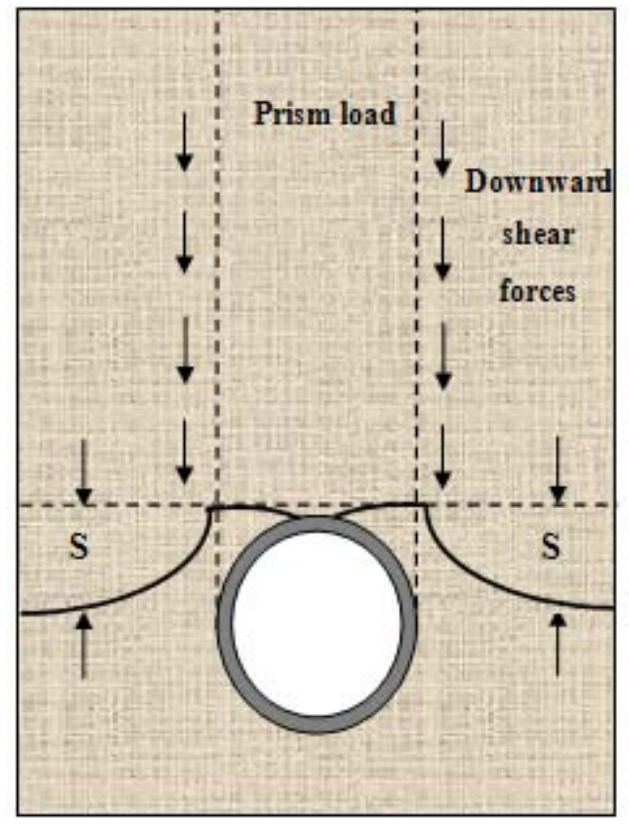

(b) Rigid Pipe

Figure 3.2: Soil arching (Gondle and Siriwardane,2008). 


\section{Chapter 4: CREEP RESPONSE OF BURIED PIPES}

\subsection{Introduction}

Pipe materials such as high density polyethylene (HDPE), polyvinyl chloride (PVC), and concrete undergo creep. A material is said to creep when it undergoes continuous deformation with time under a constant load. Rate of creep is directly proportional to stress at a given temperature (Uni-Bell PVC Pipe Association, 2001). A pipe does not fail immediately after the application of load. First, an instantaneous deformation occurs, after which the pipe material undergoes permanent deformation over a period of time before it fails (Gondle and Siriwardane, 2008). Under long term conditions, loads persistent on flexible pipes may cause large deformations leading to pipe failure. It has been specified in the literature that a vertical change of diameter up to 5\% is considered safe for buried pipes (Goddard, 2003; ADS, 2006; Plastic Pipe Institute, 2005; Reddy and Ataoglu, 2002).

\subsection{Time dependant behavior of plastic pipe materials}

When compared to linear elastic and time independent materials, the response of thermoplastic materials (HDPE and PVC) to external loads is different. These materials undergo instantaneous deformation under load, which is elastic in nature. With passage of time, permanent deformation takes place, which is irreversible. These materials are characterized by two approximately equal parameters called creep modulus and relaxation modulus. Depreciation in the long term values of creep and relaxation modulus occurs with an increase in strain due to creep or decrease in stress due to relaxation (Gabriel and Goddard, 1999). Laboratory experiments can be performed on pipe specimens to examine the creep behavior. In laboratory tests, the pipe specimen is allowed to creep under sustained load. The vertical change in diameter of a pipe at certain intervals of time is recorded and used to calculate the creep modulus of the pipe material. With the help of creep data, short term and long term pipe modulus of a buried pipe can 
be calculated (Janson, 1985). Creep modulus for a linear visco-elastic material can be expressed as below (Arvidsson and Gronvall, 2004):

$$
\mathrm{E}_{\mathrm{t}}=\frac{\sigma}{\varepsilon(\mathrm{t})}
$$

Thermoplastic materials also undergo stress relaxation with time. When a material is held at constant strain, a decrease in stress occurs with time. This is called stress relaxation. The time dependent modulus of the material can be calculated by substituting the values of deflection $(\varepsilon)$ and measured load $\left(\sigma_{t}\right)$ in the equation shown below (Arvidsson and Gronvall, 2004):

$$
\mathrm{E}_{\mathrm{t}}=\frac{\sigma_{\mathrm{t}}}{\varepsilon}
$$

Elastic constants alone cannot be used to describe the relationship between stress and strain. Thus, a new parameter called secant modulus $E_{t}$ was introduced to describe the time dependent response of a visco-elastic material. Secant modulus can be defined as the ratio of total stress $\sigma_{\mathrm{t}}$ to total strain $\varepsilon(\mathrm{t})$. It can be expressed as (Moore and $\mathrm{Hu}, 1995$ ):

$\mathrm{E}_{\mathrm{t}}=\frac{\sigma_{\mathrm{t}}}{\varepsilon(\mathrm{t})}$ 


\subsection{Time dependant behavior of concrete pipe material}

Shrinkage and creep are two time dependent processes associated with concrete. Concrete undergoes shrinkage in the presence of air even under a no-stress condition. Apart from shrinkage, it also undergoes creep when subjected to a sustained load. Thus, concrete undergoes additional deformation, which is much greater than the magnitude of initial deformation. Shrinkage of concrete can be defined as the time dependent strain measured at constant temperature in an unrestrained concrete specimen subjected to zero stress (Gilbert, 2001). Creep on the other hand is the non-plastic strain in concrete under sustained load. Total deflection in a concrete specimen is the sum of the short-term (instantaneous) and time-dependent deflection caused by the dead load (including selfweight), the prestress (if any), the expected in-service live load, and the load-independent effects of shrinkage and temperature changes. Creep of concrete is dependent on the age of concrete during loading; type of aggregates used, and mix proportions. In reinforced concrete pipes, creep increases the deflection with time and may be a critical consideration in design.

\subsection{Background of creep models}

Time dependent elastic modulus $\left(E_{t}\right)$ is one of the important parameters required in the creep analyses of buried pipes. Power law models are used to express elastic modulus as a function of time, as reported in previous studies (Gondle \& Siriwardane 2008; Hashash 1991; Janson 1985; Chua, 1986; Bazant \& Osman, 1976 and Bazant \& Chern, 1986). Such power law models can be obtained from laboratory data by performing stress relaxation tests on pipes. Laboratory measurements related to stress relaxation tests of thermoplastic pipes and creep tests corresponding to concrete can be found elsewhere (Hashash 1991; Janson 1985; Chua 1986; Janson 1995; L’Hermite et al, 1965). In the stress relaxation tests, relaxation modulus is calculated for a given time period based on the relationship between strain and the measured load. The computed modulus is plotted against time to a logarithmic scale. To predict the long term creep 
behavior of pipes used in this study, a general power law equation was used to extrapolate data available from short term relaxation tests for a time period of 50 years. The power law equation can be expressed in terms of material constants $E_{i}$ and $m$ as (Chua, 1986):

$\mathrm{E}_{\mathrm{t}}=\mathrm{E}_{\mathrm{i}} \mathrm{t}^{-\mathrm{m}}$

Where $\mathrm{E}_{\mathrm{i}}$ is the $\mathrm{y}$-intercept (initial modulus) and $\mathrm{m}$ is the creep rate indicated by the slope of the line shown in Figure 4.1. Limited information on creep properties of PVC, concrete and steel is available in the literature. Since steel has high melting point and usually creeps well above room temperature, creep properties are not significant under low temperatures (Ashby et al, 2009). Power law models available in the literature for high density polyethylene (HDPE), polyvinyl chloride (PVC) and concrete pipe materials are presented in the following sections. 


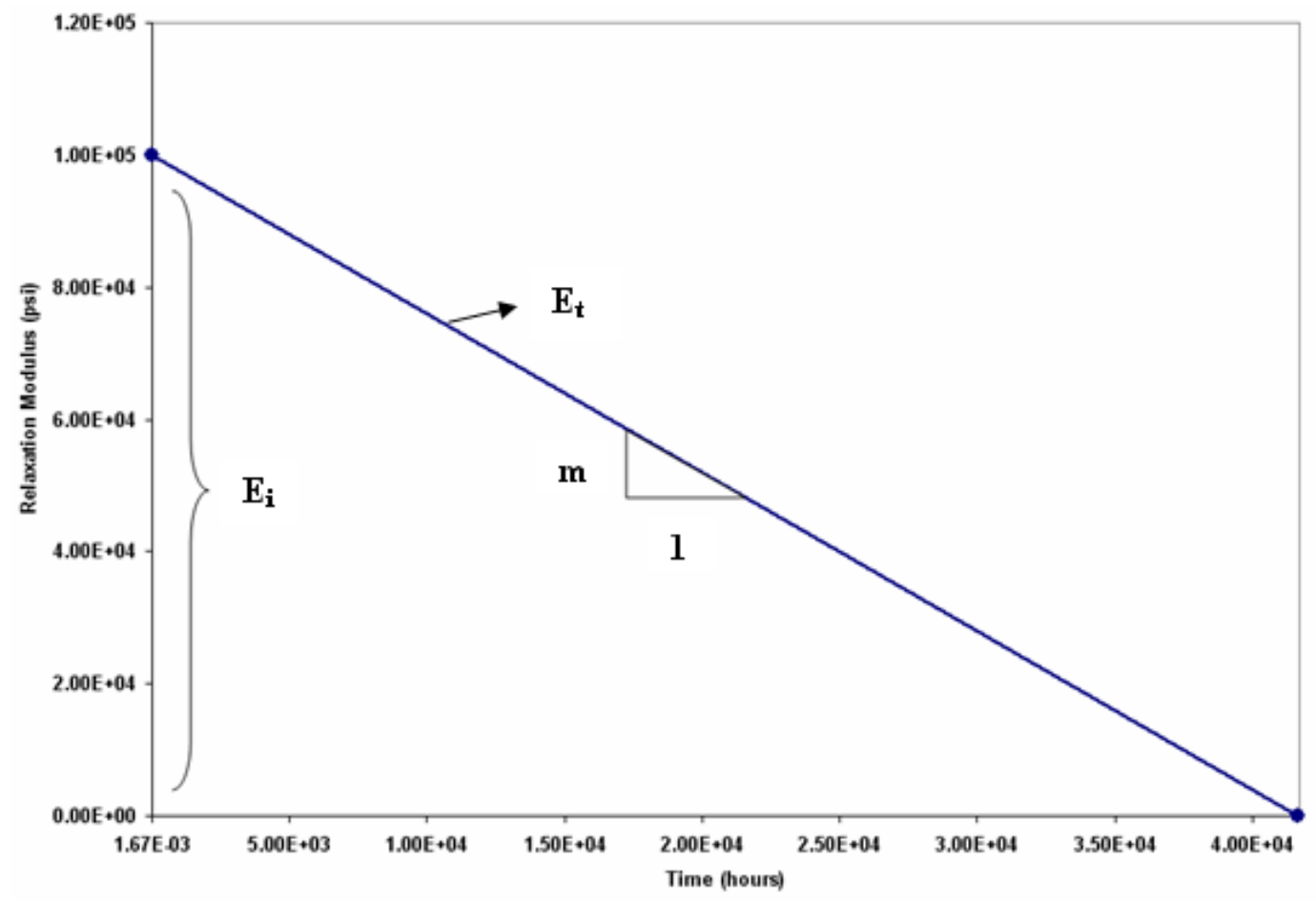

Figure 4.1: General power law form of time dependent creep behavior.

\subsubsection{Power law models for HDPE pipes}

Considerable research has been done to study the time dependent behavior of high density polyethylene (HDPE) pipes in the last three decades. Constitutive models have been proposed based on the long term creep behavior of HDPE pipes (Janson, 1985; Chua; 1986; Petroff, 1993; Hashash, 1991). A brief description of some of these models is given below.

Laboratory tests were performed by Janson (1985) on various high density and medium density polyethylene pipes of external diameter of 12.60 inches $(0.315 \mathrm{~m})$. The objective of these tests was to simulate stress relaxation in pipe rings held at constant deflection. The load required to deflect the pipe rings such that the strain rate is in the range of $0.8 \%$ to $3.7 \%$ was measured continuously for a time period of 10,000 hours. The relaxation modulus obtained using the pipe stiffness equation (Chapter 2) was plotted 
against the logarithmic scale of time. Using an extrapolation technique the line representing the time dependent modulus $\left(\mathrm{E}_{\mathrm{t}}\right)$ was extended to a time period of 50 years. The relation for $E_{t}$ at different vertical deflections is as shown below:

At 4.6\% vertical ring deflection (Janson, 1985):

$\mathrm{E}_{\mathrm{t}}=\frac{\sigma}{\varepsilon(\mathrm{t})}=520 \mathrm{t}^{-0.0795}$

where $E_{t}$ the relaxation modulus in MPa and $t$ is the time in hours

At $13.7 \%$ vertical ring deflection (Janson 1985):

$\mathrm{E}_{\mathrm{t}}=\frac{\sigma}{\varepsilon(\mathrm{t})}=350 \mathrm{t}^{-0.0672}$

where $\mathrm{E}_{\mathrm{t}}$ the relaxation modulus in MPa and $\mathrm{t}$ is the time in hours

Compression tests were performed by Chua (1986) on high density polyethylene pipes manufactured by Spirolite, United States. Chua (1986) proposed a simple power law model which is expressed as:

$\mathrm{E}_{\mathrm{t}}=\mathrm{E}_{\infty}+\mathrm{E}_{\mathrm{i}} \mathrm{t}^{-\mathrm{m}}$

Where $E_{i}$ is the initial relaxation modulus, $E_{\infty}$ is the long term relaxation modulus, and $\mathrm{m}$ is the creep rate, which was assumed to be 0.098 for HDPE material. The time dependent relaxation modulus proposed by Chua (1986) is as shown below: 


$$
\mathrm{E}_{\mathrm{t}}=\frac{\sigma}{\varepsilon(\mathrm{t})}=7630+99507 \mathrm{t}^{-0.097786}
$$

Where $\mathrm{E}_{\mathrm{t}}$ is given in psi and time, $\mathrm{t}$ is measured in hours.

This equation has also been expressed as shown below (Chehab and Moore, 2004):

$$
\mathrm{E}_{\mathrm{t}}=\frac{\sigma}{\varepsilon(\mathrm{t})}=52.6+460 \mathrm{t}^{-0.097786}
$$

Where $\mathrm{E}_{\mathrm{t}}$ is given in Mpa and time, $\mathrm{t}$ is measured in hours.

Laboratory tests were performed by Hashash (1991) to determine the long term performance of corrugated HDPE pipes. The tests included both creep and long term stress relaxation. In the creep tests, lined and unlined corrugated HDPE pipes of various diameters were held at deflection rates varying between $0.0004 \%$ / $\mathrm{min}$ and $3 \% / \mathrm{min}$. The creep tests were performed according to ASTM D 2412 and the pipe sections were compressed to a maximum of $30 \%$ change in the vertical inner diameter. The applied load, vertical pipe deflections, and horizontal pipe deflections were monitored at regular time intervals.

It has been reported by Hashash (1991)) that with the increase in rate of deformation the stiffness factor (EI) also increased. For all deformation rates the stiffness factor decreased with time. The degradation in the pipe stiffness factor increased with an increase in pipe diameter. Deformation rates had no influence on the relationship that existed between pipe stiffness and stiffness factor. The elastic modulus of the pipe was found to be dependent on both the pipe size and on the presence of a liner.

The power law proposed by Hashash (1991) can be expressed as:

$$
E_{t}=96,300 t^{-0.0859}
$$


where $\mathrm{E}_{\mathrm{t}}$ is expressed in psi and $\mathrm{t}$ in minutes.

It can also be expressed in metric units as shown below (Gondle and Siriwardane, 2008)

$$
\mathrm{E}_{\mathrm{t}}=467 \mathrm{t}^{-0.0859}
$$

where $\mathrm{E}_{\mathrm{t}}$ is expressed in $\mathrm{MPa}$ and $\mathrm{t}$ in hours

Equation 4.10 can be used to extrapolate the test data to 50 years. "The short term modulus computed and the long term modulus obtained from extrapolation was in good agreement with AASHTO recommended values. AASHTO recommended modulus values of $758 \mathrm{MPa}(110,000 \mathrm{psi})$ and $152 \mathrm{Mpa}$ (22,000 psi) for short-term and long-term conditions" (Gondle and Siriwardane, 2008). From the review of the theoretical creep models discussed in this section, the power law form of the model formulated by Hashash (1991) is a conservative model to describe the creep behavior of HDPE pipes. This power law form predicts lower values of elastic modulus (i.e., higher displacements) when compared to other creep models for HDPE pipes (Janson, 1985; Chua, 1986). In different units, this model can also be expressed as (Hashash 1991):

$\mathrm{E}_{\mathrm{t}}=67,779 \mathrm{t}^{-0.0859}$

where $\mathrm{E}_{\mathrm{t}}$ is given in psi and $\mathrm{t}$ is measured in hours.

\subsubsection{Power law model for PVC pipes}

Stress relaxation tests have been performed by Janson (1995) on PVC pipes of diameter $315 \mathrm{~mm}$ at pipe ages of 1 day, 10 days, and 100 days from the manufacturing date of the pipe. During the tests, the pipes were held at a constant deflection of $5 \%$ and a corresponding bending strain of $0.67 \%$ under controlled room temperature of $23^{\circ} \mathrm{C}$. The measured relaxation modulus $\left(\mathrm{E}_{\mathrm{t}}\right)$ and its reciprocal (compliance) were plotted as a 
function of loading time of over 10,000 hours on a logarithmic scale. PVC material undergoes molecular consolidation which causes physical ageing (Janson, 1995). This effect was believed to cause a linear relationship between the compliance $\left(1 / \mathrm{E}_{\mathrm{t}}\right)$ and the logarithmic time function $\log (\mathrm{t})$, which allowed extrapolation to periods much longer than the testing time.

A comparison of the short-term and long-term relaxation modulii for the three tests performed on pipes of different ages is given in Table 4.1. Figure 4.2 shows the variation of relaxation modulus of a PVC pipe at a pipe age of 24 hours.

Table 4.1: Comparison of Relaxation Modulus at different Pipe Ages (Janson, 1995)

\begin{tabular}{|c|c|c|}
\hline $\begin{array}{c}\text { Age of pipe during loading } \\
\text { (hours) }\end{array}$ & $\begin{array}{c}\text { Short term modulus }\left(\mathbf{E}_{\text {3min }}\right) \\
\text { psi (Mpa) }\end{array}$ & $\begin{array}{c}\text { 50 years modulus }\left(\mathbf{E}_{\mathbf{5 0}}\right) \\
\text { psi(Mpa) }\end{array}$ \\
\hline 24 & $425,865(2,937)$ & $166,605(1,149)$ \\
\hline 240 & $459,215(3,167)$ & $175,740(1,212)$ \\
\hline 2,400 & $469,365(3,237)$ & $193,285(1,333)$ \\
\hline
\end{tabular}




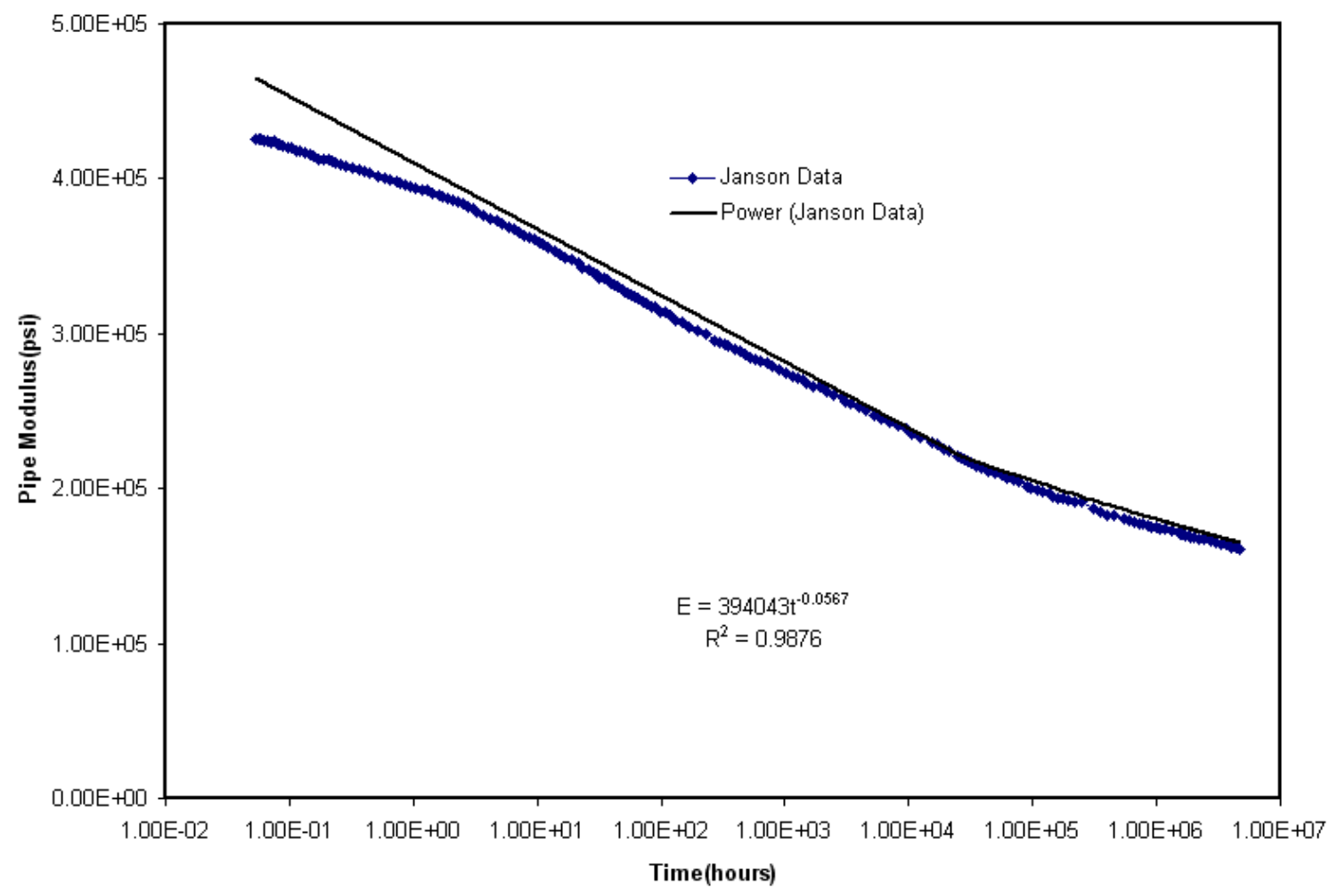

Figure 4.2: Variation in relaxation modulus of PVC with time (Modified from Janson, 1995).

A power law equation was developed from the laboratory test data represented in Figure 4.2. It can be expressed as:

$$
E_{t}=394,038 t^{-0.0567}
$$

where $E_{t}$ is given in psi and time, $t$ is measured in hours. 


\subsubsection{Power law model for concrete}

Many creep laws have been developed in the past to describe the creep phenomenon in concrete. These laws were valid only for basic creep (where there is no moisture exchange) and for short test durations. Bazant \& Osman (1976) and Bazant \& Chern (1985) formulated double power law and triple power law, respectively. These laws were developed to analyze creep data, perform statistical analyses, and extrapolate creep data. In order to test the competence of these power laws, extensive test data available in the literature (L'Hermite et al, 1965; Pirtz, 1968; Hanson, 1953; Harboe, 1958) have been fitted (Bazant \& Osman, 1976; Bazant \& Chern, 1985). Bazant and Osman (1976) demonstrated that the double power law can be used to describe the age dependence of conventional elastic modulus of concrete.

In this study, power law models were developed from the optimum fit data which were computed using the double power law and the triple power law. Creep parameters were derived from the data available for concrete specimens used in the laboratory tests performed by L'Hermite et al, (1965). These concrete specimens had material properties such as 28 day strength and water-cement ratio similar to the concrete used in the manufacturing of reinforced concrete pipes. Figure 4.3 shows the creep curves obtained by fitting a power law model to match the computed data obtained from the double power law and the triple power law. 


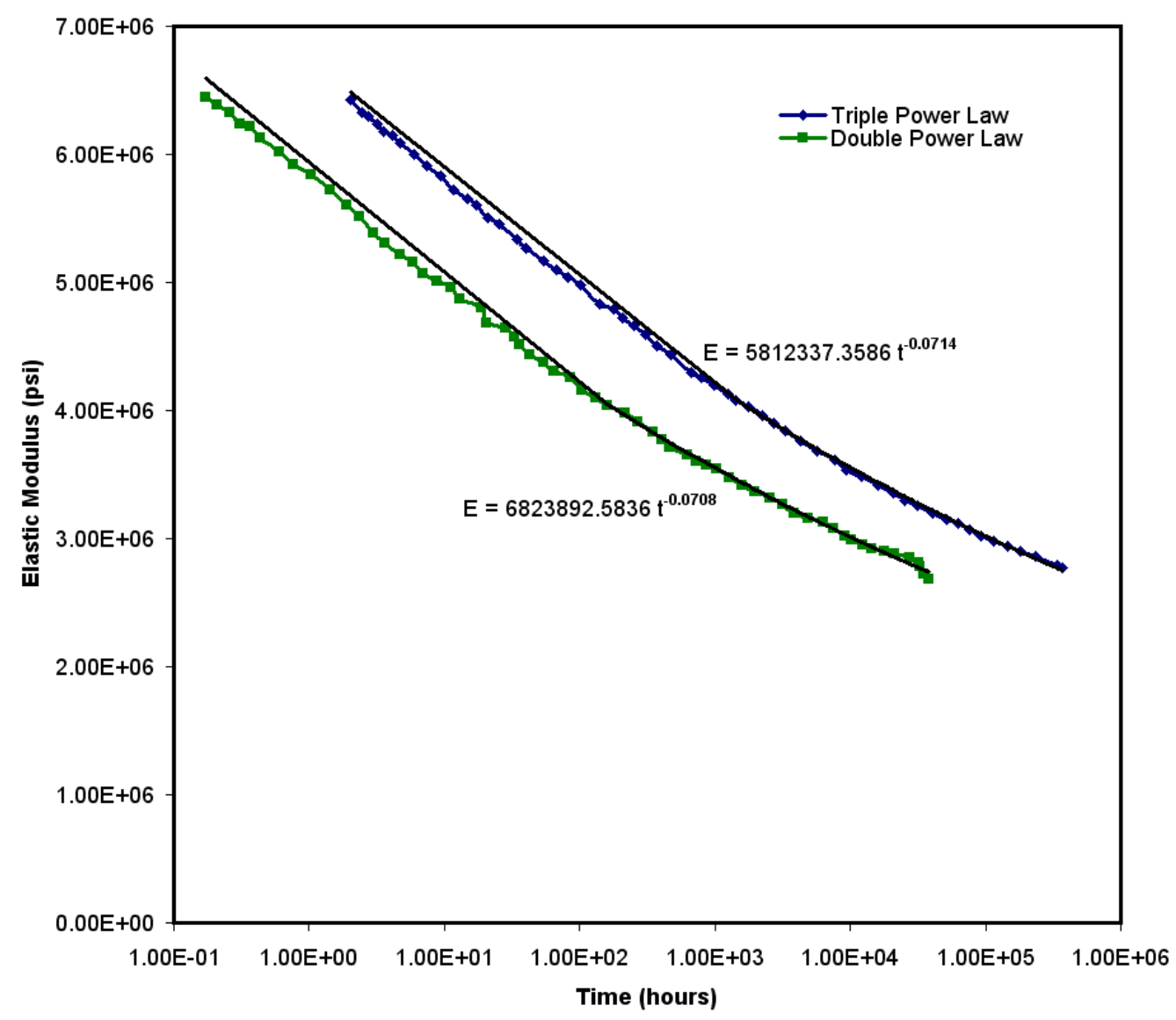

Figure 4.3: Variation in elastic modulus with time using different power laws. (Modified from Bazant and Osman, 1976; Bazant and Chern, 1985).

The power law equations obtained from the available creep data can be expressed as:

$$
\begin{aligned}
& E_{t}=5,812,337.3586 t^{-0.0714} \\
& E_{t}=6,823,892.5836 t^{-0.0708}
\end{aligned}
$$

where $E_{t}$ is in psi and $t$ is in hours

The power law model (Eq. 4.14) corresponding to the double power law equation is a conservative model to describe the creep behavior of concrete as it predicts lower 
values of elastic modulus. Therefore, the power law model given in Equation 4.14 was used in this study. 


\section{Chapter 5: PIPE MATERIALS AND ESTIMATION OF THE PIPE'S ELASTIC MODULUS}

\subsection{High density polyethylene pipes (HDPE)}

Polyethylene is characterized into low density polyethylene (LDPE) and high density polyethylene (HDPE) on the basis of its density or volume mass. High density polyethylene is stronger, harder, but less ductile than LDPE. It has been stated that high density polyethylene (HDPE) is the right choice when long term serviceability, trouble free installation, and flexibility is required (PPI, 2005). Commercially available polyethylene pipes have been categorized by AASHTO (AASHTO M 294, 2007; PPI, 2005) as follows:

Type D: This category of HDPE pipes consists of a circular cross section with smooth inner and outer surfaces.

Type S: This pipe type is also referred to as double-wall corrugated pipe which consists of a circular cross section with a smooth inner surface and a corrugated outer surface as shown in Figure 5.1.

Type C: This pipe type is also referred to as single-wall corrugated pipe which consists of a circular cross section with inner and outer corrugations as shown in Figure 5.2.

High density polyethylene pipes are lightweight allowing for easier transportation and installation costs. Due to its high durability, HDPE pipes are not susceptible to cracking during handling and installation (PPI, 2005). In the last few decades HDPE pipes have gained popularity due to their flexibility, durability, and their effectiveness in water management. Based on the application and hydraulic requirement, either a plain walled or a corrugated wall pipe is selected. The presence of inner corrugations in a single-wall corrugated pipe makes it suitable for applications that require control of water flow (ADS, 2006). In this study, the focus is on double-wall corrugated pipes, which have a corrugated surface on the outside and a smooth surface on the inside. Double-wall 
corrugated pipes have superior structural integrity due to the outer corrugations and excellent fluid flow characteristics provided by the smooth inner surfaces. Commercially available double- wall corrugated pipes range from 4 inches $(0.10 \mathrm{~m})$ to 60 inches $(1.50$ $m$ ). In the present study, the sectional properties of Type S (double-wall corrugated) HDPE pipes obtained from the literature (ADS, 2006) were used in the analysis as shown in Table 5.1. 
Table 5.1: Section Properties of Double-Wall Corrugated HDPE pipes (ADS , 2006)

\begin{tabular}{|c|c|c|c|c|c|c|c|c|}
\hline $\begin{array}{l}\text { Nominal } \\
\text { Diameter }\end{array}$ & $\begin{array}{c}\text { Inside } \\
\text { diameter }\end{array}$ & $\begin{array}{r}\text { Outside } \\
\text { diameter } \\
\text { Average }\end{array}$ & $\begin{array}{c}\text { Inner Liner } \\
\text { Thickness, } \\
\text { Minimum }\end{array}$ & $\begin{array}{l}\text { Minimum Pipe } \\
\text { stiffness at 5\% } \\
\text { deflection }\end{array}$ & $\begin{array}{l}\text { Weight } \\
\text { kg./6m }\end{array}$ & $\begin{array}{c}\text { Area } \\
\mathrm{mm}^{2} / \mathbf{m}\end{array}$ & $\begin{array}{c}" \text { I" } \\
\mathrm{cm}^{4} / \mathrm{cm}\end{array}$ & $\begin{array}{l}" \mathrm{C} " \\
\mathrm{~mm}\end{array}$ \\
\hline $\begin{array}{c}600 \mathrm{~mm} \\
\left(24^{\prime \prime}\right)\end{array}$ & $\begin{array}{l}612 \mathrm{~mm} \\
(24.08 ")\end{array}$ & $\begin{array}{l}719 \mathrm{~mm} \\
(27.80 ")\end{array}$ & $\begin{array}{l}1.5 \mathrm{~mm} \\
\left(0.059^{\prime \prime}\right)\end{array}$ & $\begin{array}{c}235 \mathrm{kN} / \mathrm{m}^{2} \\
34 \mathrm{psi}\end{array}$ & $\begin{array}{c}99.93 \mathrm{~kg} \\
(220.30 \mathrm{lbs})\end{array}$ & $\begin{array}{c}8.23 \\
\left(0.324 \mathrm{in}^{2} / \mathrm{in}\right)\end{array}$ & $\begin{array}{c}2.245 \\
\left(0.137 \mathrm{in}^{4} / \mathrm{in}\right)\end{array}$ & $\begin{array}{c}18.8 \\
(0.74 \mathrm{in})\end{array}$ \\
\hline $\begin{array}{c}750 \mathrm{~mm} \\
\left(30^{\prime \prime}\right)\end{array}$ & $\begin{array}{l}762 \mathrm{~mm} \\
\left(30.00^{\prime \prime}\right)\end{array}$ & $\begin{array}{l}892 \mathrm{~mm} \\
\left(35.10^{\prime \prime}\right)\end{array}$ & $\begin{array}{l}1.5 \mathrm{~mm} \\
\left(0.059^{\prime \prime}\right)\end{array}$ & $\begin{array}{c}195 \mathrm{kN} / \mathrm{m}^{2} \\
28 \mathrm{psi}\end{array}$ & $\begin{array}{c}140.00 \mathrm{~kg} \\
\text { (308.6 lbs) }\end{array}$ & $\begin{array}{c}9.6 \\
\left(0.378 \mathrm{in}^{2} / \mathrm{in}\right)\end{array}$ & $\begin{array}{c}4.539 \\
\left(0.277 \mathrm{in}^{4} / \mathrm{in}\right)\end{array}$ & $\begin{array}{c}21.84 \\
(0.86 \mathrm{in})\end{array}$ \\
\hline $\begin{array}{c}900 \mathrm{~mm} \\
(36 ")\end{array}$ & $\begin{array}{l}914 \mathrm{~mm} \\
\left(36.00^{\prime \prime}\right)\end{array}$ & $\begin{array}{l}1059 \mathrm{~mm} \\
\left(41.70^{\prime \prime}\right)\end{array}$ & $\begin{array}{l}1.7 \mathrm{~mm} \\
\left(0.067^{\prime \prime}\right)\end{array}$ & $\begin{array}{c}150 \mathrm{kN} / \mathrm{m}^{2} \\
22 \mathrm{psi}\end{array}$ & $\begin{array}{c}180.00 \mathrm{~kg} \\
\text { (396.8 lbs) }\end{array}$ & $\begin{array}{c}10.19 \\
\left(0.401 \mathrm{in}^{2} / \mathrm{in}\right)\end{array}$ & $\begin{array}{c}6.555 \\
\left.0.400 \mathrm{in}^{4} / \mathrm{in}\right)\end{array}$ & $\begin{array}{c}25.4 \\
(1.00 \mathrm{in})\end{array}$ \\
\hline $\begin{array}{c}1050 \mathrm{~mm} \\
(42 ")\end{array}$ & $\begin{array}{c}1054 \mathrm{~mm} \\
\left(41.40^{\prime \prime}\right)\end{array}$ & $\begin{array}{l}1212 \mathrm{~mm} \\
\left(47.70^{\prime \prime}\right)\end{array}$ & $\begin{array}{l}1.8 \mathrm{~mm} \\
\left(0.070^{\prime \prime}\right)\end{array}$ & $\begin{array}{c}140 \mathrm{kN} / \mathrm{m}^{2} \\
20 \mathrm{psi}\end{array}$ & $\begin{array}{c}230.00 \mathrm{~kg} \\
\text { (570.10 lbs) }\end{array}$ & $\begin{array}{c}11.64 \\
\left(0.458 \mathrm{in}^{2} / \mathrm{in}\right)\end{array}$ & $\begin{array}{c}9.373 \\
\left(0.572 \mathrm{in}^{4} / \mathrm{in}\right)\end{array}$ & $\begin{array}{c}30.73 \\
(1.21 \mathrm{in})\end{array}$ \\
\hline $\begin{array}{c}1200 \mathrm{~mm} \\
\left(48^{\prime \prime}\right)\end{array}$ & $\begin{array}{l}1209 \mathrm{~mm} \\
\left(47.60^{\prime \prime}\right)\end{array}$ & $\begin{array}{l}1361 \mathrm{~mm} \\
(53.60 ")\end{array}$ & $\begin{array}{l}1.8 \mathrm{~mm} \\
\left(0.070^{\prime \prime}\right)\end{array}$ & $\begin{array}{c}125 \mathrm{kN} / \mathrm{m}^{2} \\
18 \mathrm{psi}\end{array}$ & $\begin{array}{c}283.50 \mathrm{~kg} \\
(625.00 \mathrm{lbs})\end{array}$ & $\begin{array}{c}12.58 \\
\left(0.495 \mathrm{in}^{2} / \mathrm{in}\right)\end{array}$ & $\begin{array}{c}9.341 \\
\left(0.570 \mathrm{in}^{4} / \mathrm{in}\right)\end{array}$ & $\begin{array}{c}29.72 \\
(1.17 \mathrm{in})\end{array}$ \\
\hline $\begin{array}{c}1500 \mathrm{~mm} \\
(60 ")\end{array}$ & $\begin{array}{c}1512 \mathrm{~mm} \\
\left(59.5^{\prime \prime}\right)\end{array}$ & $\begin{array}{c}1684 \mathrm{~mm} \\
\left(66.3^{\prime \prime}\right)\end{array}$ & $\begin{array}{l}1.8 \mathrm{~mm} \\
\left(0.070^{\prime \prime}\right)\end{array}$ & $\begin{array}{c}95 \mathrm{kN} / \mathrm{m}^{2} \\
14 \mathrm{psi}\end{array}$ & $\begin{array}{c}410.00 \mathrm{~kg} \\
(903.90 \mathrm{lbs})\end{array}$ & $\begin{array}{c}14.68 \\
\left(0.578 \mathrm{in}^{2} / \mathrm{in}\right)\end{array}$ & $\begin{array}{c}14.09 \\
\left(0.860 \mathrm{in}^{4} / \mathrm{in}\right)\end{array}$ & $\begin{array}{c}33.66 \\
(1.32 \mathrm{in})\end{array}$ \\
\hline
\end{tabular}




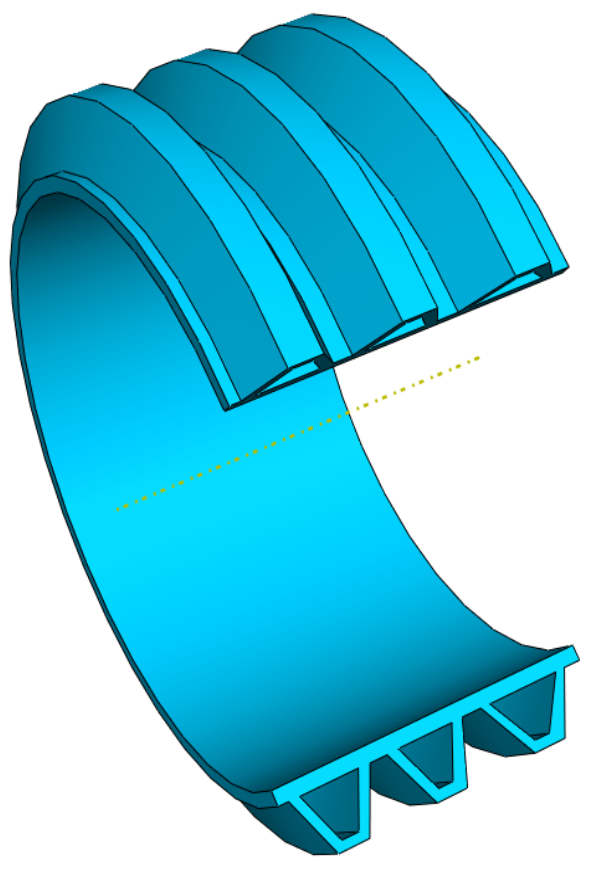

(a) Double-wall corrugated HDPE pipe

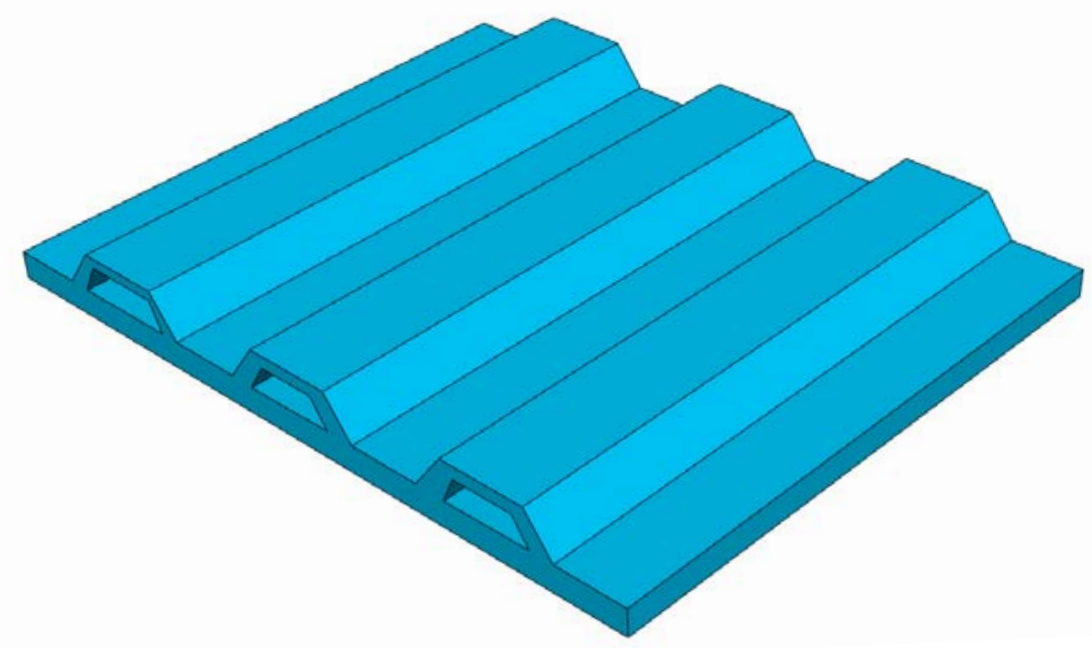

(b) Geometry of the double-wall corrugated HDPE pipe

Figure 5.1: Profile view of double-wall corrugated HDPE pipe. 


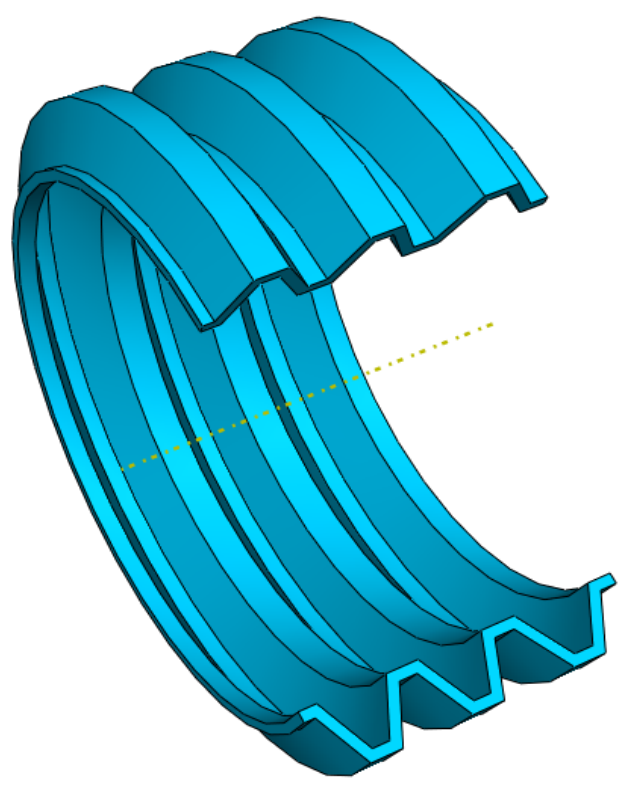

(a) Single-wall corrugated HDPE pipe

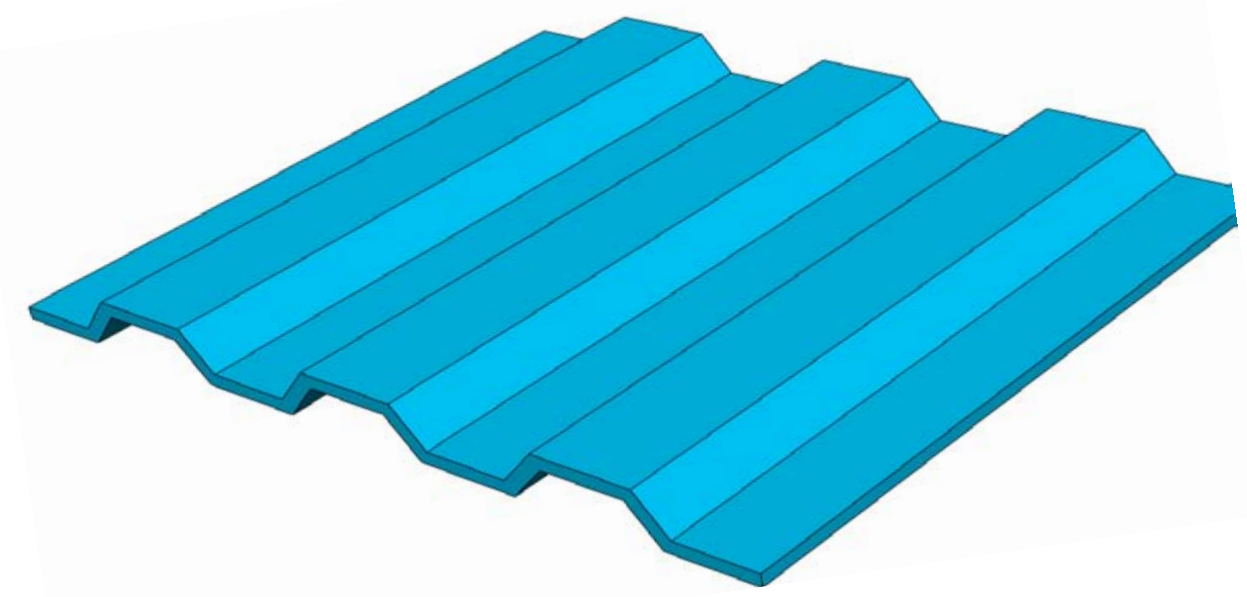

(b) Geometry of the single-wall corrugated HDPE pipe

Figure 5.2: Profile view of single-wall corrugated HDPE pipe. 


\subsubsection{Estimation of Elastic modulus of Type S HDPE pipe}

In two dimensional finite element analyses of HDPE pipes, it is difficult to model geometrical features such as corrugations which maybe present on the inside or the outside surface of the circular pipe section. Thus, it is assumed that the pipe has a rectangular cross-section having the same structural stiffness as the corrugated section as shown in Figure 5.3. The method used to determine the elastic modulus for a Type $S$ (double-wall corrugated) pipe is shown below using a 36-inch $(0.90 \mathrm{~m})$ pipe whose sectional properties were obtained from Table 5.1:

For a 36-inch (0.90 m) nominal pipe diameter (Figure 5.3):

Min. Pipe stiffness@ @\% deflection (K) = 22 psi

Inside diameter (ID) $\quad=36.00 \mathrm{in}$.

Outside diameter (OD) $\quad=41.70 \mathrm{in}$.

Moment of inertia $\left(\mathrm{I}_{\mathrm{d}}\right) \quad=0.400 \mathrm{in}^{4} / \mathrm{in}$.

Distance from inner wall to neutral axis $(C)=1.00 \mathrm{in}$.

Flexural modulus of the pipe $\left(\mathrm{E}_{\mathrm{d}}\right) \quad=110,000 \mathrm{psi}$

Mean diameter $\left(\mathrm{D}_{\text {mean }}\right)=$ Inside diameter $(\mathrm{ID})+2 \mathrm{C}$

$$
=36.00+2(1.00)=38.00 \mathrm{in} \text {. }
$$

Therefore, mean radius $\left(\mathrm{r}_{\text {mean }}\right)=19.00 \mathrm{in}$.

The thickness of the pipe can be calculated as shown below:

$\mathrm{t}=\frac{(\mathrm{OD}-\mathrm{ID})}{2}$

Where 
$\mathrm{t}=$ thickness of pipe (in)

$\mathrm{OD}=$ Outside diameter of pipe (in.)

ID = Inside diameter of pipe (in.)

Therefore, the thickness for a 36-inch $(0.90 \mathrm{~m})$ pipe can be calculated by using Equation 5.2 as:

$\mathrm{t}=\frac{(41.70-36.00)}{2}=2.85 \mathrm{in}$

The obtained value is the thickness used to idealize the cross-section of the pipe as a rectangular section. Thus, the moment of inertia can be calculated as:

$\mathrm{I}_{\mathrm{p}}=\frac{\mathrm{t}^{3}}{12}=\frac{2.85^{3}}{12}=1.9291$ in. $^{4} / \mathrm{in}$

In the above steps the geometric stiffness has been altered. In order to maintain equilibrium the material stiffness has to be modified. The alteration is shown below:

$$
E_{d} I_{d}=E_{p} I_{p}
$$

where

$E_{d}=$ Elastic modulus of corrugated section for double-wall pipe.

$\mathrm{E}_{\mathrm{p}}=$ Elastic modulus of idealized rectangular section.

$I_{d}=$ Moment of Inertia of corrugated section for double-wall pipe.

$\mathrm{I}_{\mathrm{p}}=$ Moment of Inertia of idealized rectangular section

Therefore, 
$E_{p}=\frac{E_{d} I_{d}}{I_{p}}=\frac{110,000 * 0.4}{1.9291}=22,808.56 p s i$

The above method is employed in the determination of suitable thickness and material stiffness for various sizes of pipes used in this study. 

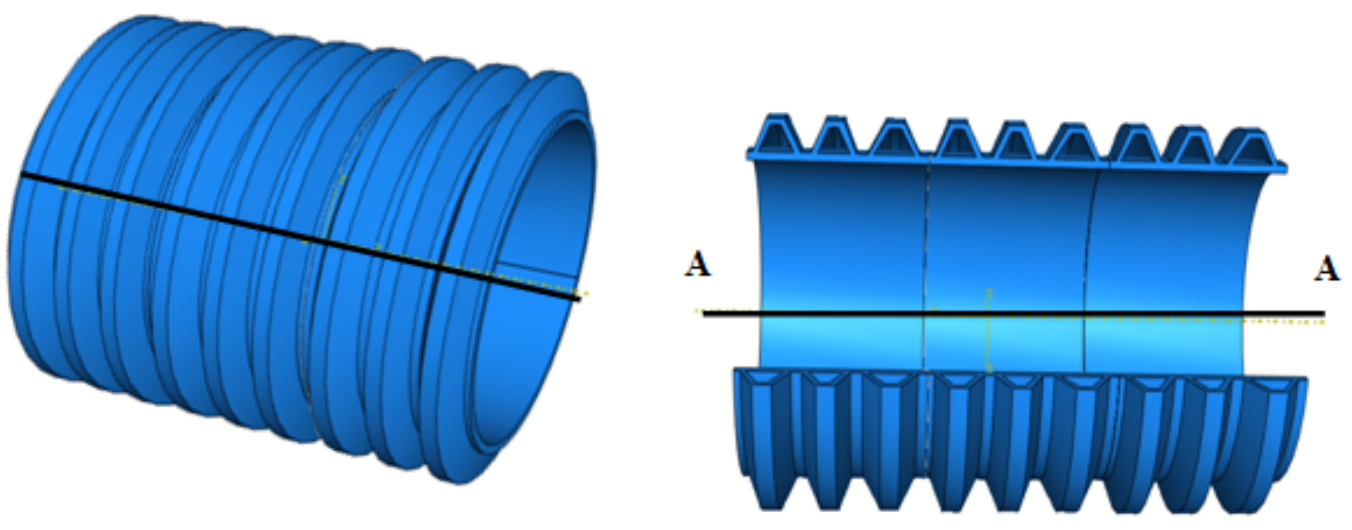

(a) Double-wall corrugated HDPE pipe
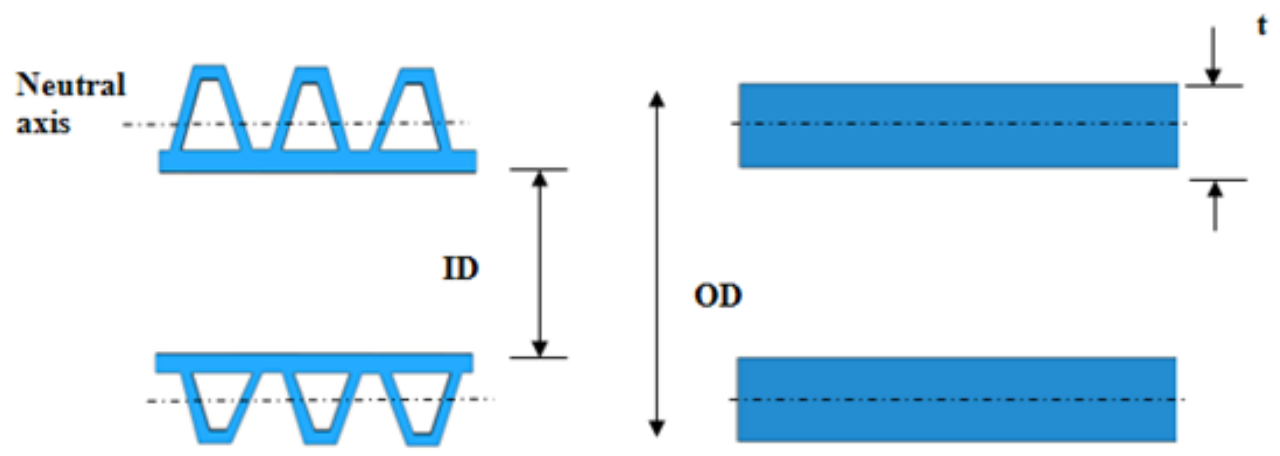

(b) Section A-A of double-wall pipe

(c) Idealized section of double-wall pipe

Figure 5.3: Typical cross section of double-wall corrugated HDPE pipe. 


\subsection{Polyvinyl chloride pipes (PVC)}

Most commercially available plastic pipes are made out of materials known as thermoplastics. The majority of thermoplastic piping market consists of polyvinyl chloride (PVC) followed by polyethylene (Moser, 2008). As per ASTM D 1784, there are two types of PVC which are used in the manufacture of plastic pipes and fittings. They are unplasticized polyvinylchloride (U-PVC) also known as rigid PVC or Type I and Type II PVC. Rigid PVC consists of small quantities of processing aids and other additives. The main features are high tensile, flexural strength, elastic modulus, and chemical resistance. Type II PVC on the other hand has additives such as rubber which makes it more flexible. Type II PVC has comparatively low tensile strength, flexural strength, lower modulus of elasticity, lower heat stability, and less chemical resistance than Type I (Willoughby, 2002). According to Moser (2008), PVC makes up to 90\% of all plastic pressure pipes and almost $100 \%$ of plastic sewer pipes. Given below are few advantages of PVC pipes (Najafi and Iseley, 1994):

- Lightweight and easy to handle

- Good impact resistance and toughness

- Resistance to wide range of corrosive environments found in soil and sewage

- Good hydraulic flow characteristics

- Excellent abrasive resistance

Non-pressure pipes also known as gravity pipes are used in sanitary sewers, storm sewers, and highway drainage applications. There are two types of PVC gravity pipes: solid-wall and profile-wall pipes (Figure 5.4). Profile-wall pipes are subdivided into three categories namely open profile (OP), closed profile (CP), and dual-wall corrugated profile (DWCP). Open profile pipes are manufactured as per the requirements of ASTM F 794. These pipes have their rib-enforcements exposed on the outside of the pipe. The closed profile wall or honey comb pipes have a continuous hollow outer wall sections. These pipes are manufactured as per the requirements of ASTM F 1803. The double-wall 
corrugated wall pipes which have smooth interior surface and corrugated external surfaces are manufactured as per ASTM F794 AND F949 (Uni-Bell, 2007). Figure 5.4 shows different types of PVC pipes.

In this study, solid-wall PVC pipes (type II) which are manufactured as per ASTM D 3034 and F679 are considered (Figure 5.4c). These pipes are made up of continuous walls of PVC of uniform thickness with smooth inner and outer surfaces. Solid-wall pipes are manufactured for both pressure and non-pressure applications. The smooth inner surfaces ensure better hydraulic performance and also reduce unwanted byproduct buildup. PVC pipes have larger internal diameters when compared to HDPE pipes owing to their high tensile strengths (Diamond Plastics, 2005). Table 5.2 shows the physical and mechanical properties of PVC pipes.

Table 5.2: Physical and Mechanical Properties of Solid-Wall PVC Pipes ${ }^{+}$

\begin{tabular}{|c|c|c|}
\hline Property & ASTM Test & Minimum value \\
\hline Specific gravity & D792 & 1.40 \\
\hline Tensile Strength & D638 & Initial value 7,000 psi \\
\hline Elastic Modulus & D638 & Initial value 400,000 psi \\
\hline IZOD Impact Strength & D256 & $0.65 \mathrm{lb} / \mathrm{in}$. \\
\hline
\end{tabular}

+Reference: (AASHTO, 2007; Diamond Plastics, 2005) 


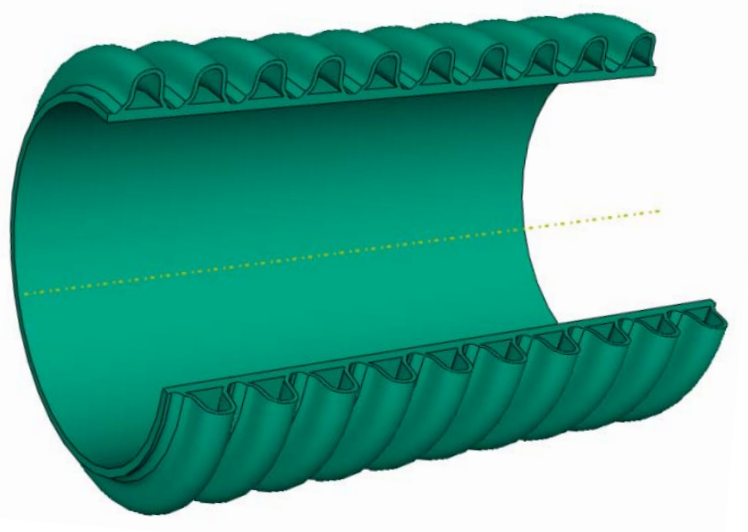

(a) Dual-wall closed profile pipe

(b) Open profile pipe
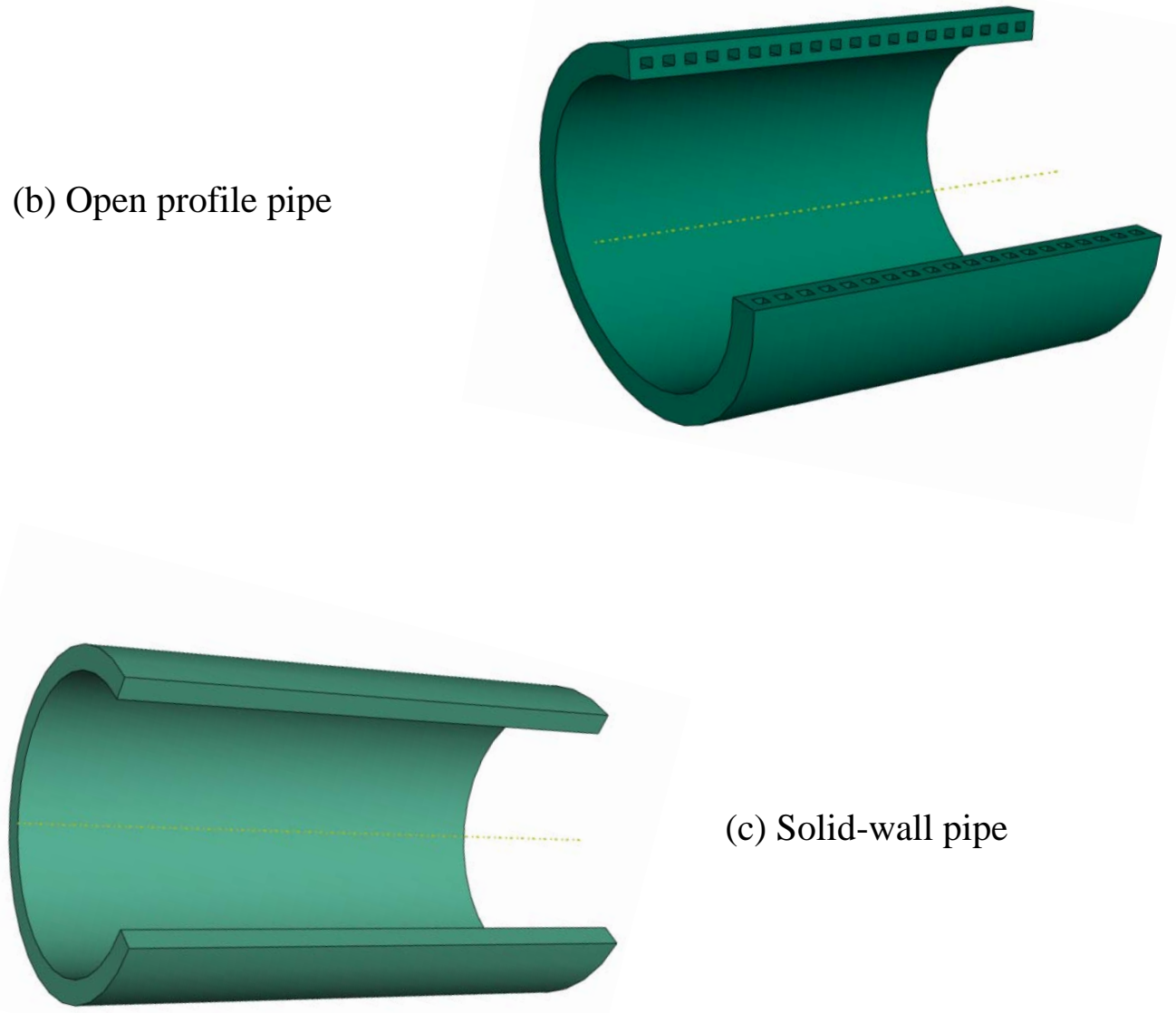

(c) Solid-wall pipe

Figure 5.4: Typical cross section of profile wall and solid wall PVC pipes. 
In order to maintain pressure ratings at standard temperature, solid wall pipes are also available in Standard Dimension Ratio (SDR). Standard dimension ratio is defined as the ratio between pipe diameter and the pipe thickness. This ratio alters the dimensions of the pipe in order to maintain maximum allowable pressure ratings. Table 5.3 shows the pipe stiffness values for different SDR pipes. In this study, pipes with SDR value of 35 were considered.

Table 5.3: Pipe Stiffness of PVC Pipes ${ }^{+}$

\begin{tabular}{|c|c|c|}
\hline \multirow{2}{*}{ Standard Dimension Ratio } & \multicolumn{2}{|c|}{ Pipe Stiffness(psi) } \\
\cline { 2 - 3 } & $\mathbf{E}=\mathbf{4 0 0 , 0 0 0}$ psi & $\mathbf{E}=\mathbf{5 0 0 , 0 0 0}$ psi \\
\hline 41 & 28 & 35 \\
\hline 35 & 46 & 57 \\
\hline 26 & 115 & 144 \\
\hline
\end{tabular}

+ Reference: (Diamond Plastics,2005)

In the present study, the specification data values of solid wall PVC pipes (ASTM D3034 \& F679) were selected on the basis of available information as shown in Table 5.4 (Diamond-Plastics,2005). 
Table 5.4: Specification Data for D 3034 \& F 679 PVC pipes $^{+}$

\begin{tabular}{|c|c|c|c|}
\hline $\begin{array}{l}\text { Nominal pipe size } \\
\text { inches (m) }\end{array}$ & $\begin{array}{l}\text { Outside Diameter } \\
\text { inches (m) }\end{array}$ & $\begin{array}{c}\text { Wall Thickness(t) } \\
\text { SDR26/PS115 } \\
\text { inches (m) }\end{array}$ & $\begin{array}{c}\text { Wall Thickness(t) } \\
\text { SDR35/PS46 } \\
\text { inches(m) }\end{array}$ \\
\hline \multicolumn{4}{|c|}{ D 3034 Pipe Dimension } \\
\hline $4(0.10)$ & $4.215(0.110)$ & $0.162(0.004)$ & $0.120(0.003)$ \\
\hline $6(0.15)$ & $6.275(0.160)$ & $0.241(0.006)$ & $0.180(0.005)$ \\
\hline $8(0.20)$ & $8.400(0.210)$ & $0.323(0.008)$ & $0.240(0.006)$ \\
\hline $10(0.25)$ & $10.500(0.260)$ & $0.404(0.010)$ & $0.300(0.008)$ \\
\hline $12(0.30)$ & $12.500(0.310)$ & $0.481(0.012)$ & $0.360(0.009)$ \\
\hline $15(0.38)$ & $15.300(0.380)$ & $0.588(0.015)$ & $0.437(0.011)$ \\
\hline \multicolumn{4}{|c|}{ F-679 Pipe Dimension } \\
\hline $18(0.45)$ & $18.701(0.468)$ & $0.671(0.017)$ & $0.499(0.012)$ \\
\hline $21(0.53)$ & $22.047(0.551)$ & $0.791(0.020)$ & $0.588(0.015)$ \\
\hline $24(0.60)$ & $24.803(0.620)$ & $0.889(0.022)$ & $0.661(0.017)$ \\
\hline $27 *(0.68)$ & $27.953(0.699)$ & $1.002(0.025)$ & $0.745(0.019)$ \\
\hline $30 *(0.75)$ & $32.000(0.800)$ & $1.148(0.029)$ & $0.853(0.021)$ \\
\hline $36 *(0.90)$ & $38.300(0.958)$ & $1.373(0.034)$ & $1.021(0.026)$ \\
\hline $42 *(1.05)$ & $44.500(1.113)$ & -- & $1.187(0.030)$ \\
\hline $48 *(1.20)$ & $50.800(1.270)$ & -- & $1.355(0.034)$ \\
\hline
\end{tabular}

+ Reference: (Diamond Plastics, 2005) 


\subsection{Corrugated steel pipes (CSP)}

Corrugated steel pipes, which were first manufactured in 1896, continue to play a major role in modern highway engineering (NCSPA, 2008). Millions of installations in the last 100 years have demonstrated that the corrugated steel pipes are widely used in construction technologies for both drainage and non-drainage systems. Corrugated steel pipes are available in various sizes and shapes. Commercially available pipe diameters range from 6 inch $(0.15 \mathrm{~m})$ to over 600 inch $(15 \mathrm{~m})$. Wide ranges of shapes are available which includes round, arch, and box designs (NCSPA, 2008). These shapes are available in a number of span and rise dimension combinations as shown in Table 5.5. Steel pipes are manufactured in the factory under controlled environments and are fabricated to meet specifications. The strength and integrity of the soil-steel interaction allows corrugated steel pipes to be placed safely even at a depth in excess of $100 \mathrm{ft}$ (NCSPA, 2008). Corrugated steel pipes are longer due to their high beam strength when compared to pipes manufactured from other materials. Corrugated steel pipes are durable even under harsh conditions. They are available with protective base metal and metallic coatings such as zinc coated steel, aluminum coated steel (aluminized), and aluminum-zinc coated steel (NCSPA, 2008). The service life of a steel pipe can be extended to over 100 years (NCSPA, 2008). The advantages of corrugated steel pipes are (NCSPA, 2008):

- Ease of installation

- Less equipment and time required for installations.

- Insensitive to temperature or moisture extremes and can be installed even during rough weather.

- Rapid installation and inherent strength of steel enables contractor to make more efficient use of equipment.

- Heavy earth movers can operate over corrugated steel structures after a proper covering with soil, shortening the time trenches must be left open and allowing the project to progress quickly. 
Table 5.5: Shapes and Sizes of Corrugated Steel Conduits (NCSPA, 2008)

\begin{tabular}{|l|c|}
\hline Shape & Range of sizes \\
\hline Vertical ellipse in. -612 in. \\
\hline F\% nominal
\end{tabular}

When a flat sheet is corrugated an increase in stiffness and strength can be attained. Circular arcs, alternating tangent segments or alternating rectangular ribs, and flat segments are the different types of corrugation profiles used for pipes or conduits (Contech, 2005). Pitch, depth, and inside forming radius are the parameters used to describe a corrugated profile, as shown in Figure 5.5. Table 5.6 shows the corrugation profile dimensions applicable to different types of steel pipes. 
Table 5.6: Corrugation for Different Types of Steel Pipes (NCSPA, 2008)

\begin{tabular}{|l|c|}
\hline \multicolumn{1}{|c|}{ Type } & \multicolumn{1}{|c|}{$\begin{array}{c}\text { Corrugations } \\
\text { Pitch vs. Depth dimensions }\end{array}$} \\
\hline $\begin{array}{l}\text { Riveted or resistance spot-welded pipes with } \\
\text { annular seams }\end{array}$ & $22 / 3$ in. $x \frac{1}{2} 2$ in., 3 in. $x 1$ in. \\
\hline $\begin{array}{l}\text { Small diameter sub drain pipes } \\
\text { Large diameter pipes( diameters to } 144 \text { inches } \\
\text { depending on profile) }\end{array}$ & 2 in. $x \frac{1}{1 / 2}$ in. 3 in. 3 in. 1 in., 5 in. $x 1$ in. \\
\hline
\end{tabular}

In this study, the focus is on corrugated steel pipes with circumferential or annular seams. Corrugation profiles available for these pipes are shown in Figure 5.5.Corrugation with pitch vs. depth of 3 inch $\mathrm{x} 1$ inch has been chosen to perform the analysis in this study. The sectional properties of this annular corrugation (Figure 5.5) are shown in Table 5.7 
Table 5.7: Sectional Properties of 3 inch $x 1$ inch (Annular or Helical) Corrugation (NCSPA, 2008)

\begin{tabular}{|c|c|c|c|c|c|c|c|c|}
\hline $\begin{array}{c}\text { Specified } \\
\text { thickness } \\
\text { (in.) }\end{array}$ & $\begin{array}{c}\text { Uncoated } \\
\text { thickness } \\
T \\
\text { (in.) }\end{array}$ & $\begin{array}{c}\text { Area of } \\
\text { section } \\
\text { A } \\
\left.\text { (in. }{ }^{2} / \mathrm{ft}\right)\end{array}$ & $\begin{array}{c}\text { Tangent } \\
\text { length } \\
\text { TL } \\
\text { (in.) }\end{array}$ & $\begin{array}{c}\text { Tangent } \\
\text { angle } \\
\Delta \\
\text { (degrees) }\end{array}$ & $\begin{array}{c}\text { Moment of } \\
\text { Inertia } \\
\text { I } \\
\text { (in. } / \text { /in) }\end{array}$ & $\begin{array}{c}\text { Section } \\
\text { Modulus } \\
\text { S } \\
\left(\text { in. }^{3} / \mathrm{ft}\right)\end{array}$ & $\begin{array}{c}\text { Radius of } \\
\text { gyration } \\
\mathbf{r} \\
\text { (in.) }\end{array}$ & $\begin{array}{l}\text { Developed } \\
\text { width factor }\end{array}$ \\
\hline $0.040^{*}$ & 0.0359 & 0.534 & 0.963 & 44.19 & 0.0052 & 0.1194 & 0.3403 & 1.239 \\
\hline 0.052 & 0.0478 & 0.711 & 0.951 & 44.39 & 0.0069 & 0.1578 & 0.3410 & 1.240 \\
\hline 0.064 & 0.0598 & 0.890 & 0.938 & 44.60 & 0.0087 & 0.1961 & 0.3417 & 1.240 \\
\hline 0.079 & 0.0747 & 1.113 & 0.922 & 44.87 & 0.0109 & 0.2431 & 0.3427 & 1.241 \\
\hline 0.109 & 0.1046 & 1.560 & 0.889 & 45.42 & 0.0146 & 0.3358 & 0.3448 & 1.243 \\
\hline 0.138 & 0.1345 & 2.008 & 0.855 & 46.02 & 0.0202 & 0.4269 & 0.3472 & 1.244 \\
\hline 0.168 & 0.1644 & 2.458 & 0.819 & 46.65 & 0.0251 & 0.5170 & 0.3499 & 1.246 \\
\hline
\end{tabular}

* Thickness not commonly available. Information only 


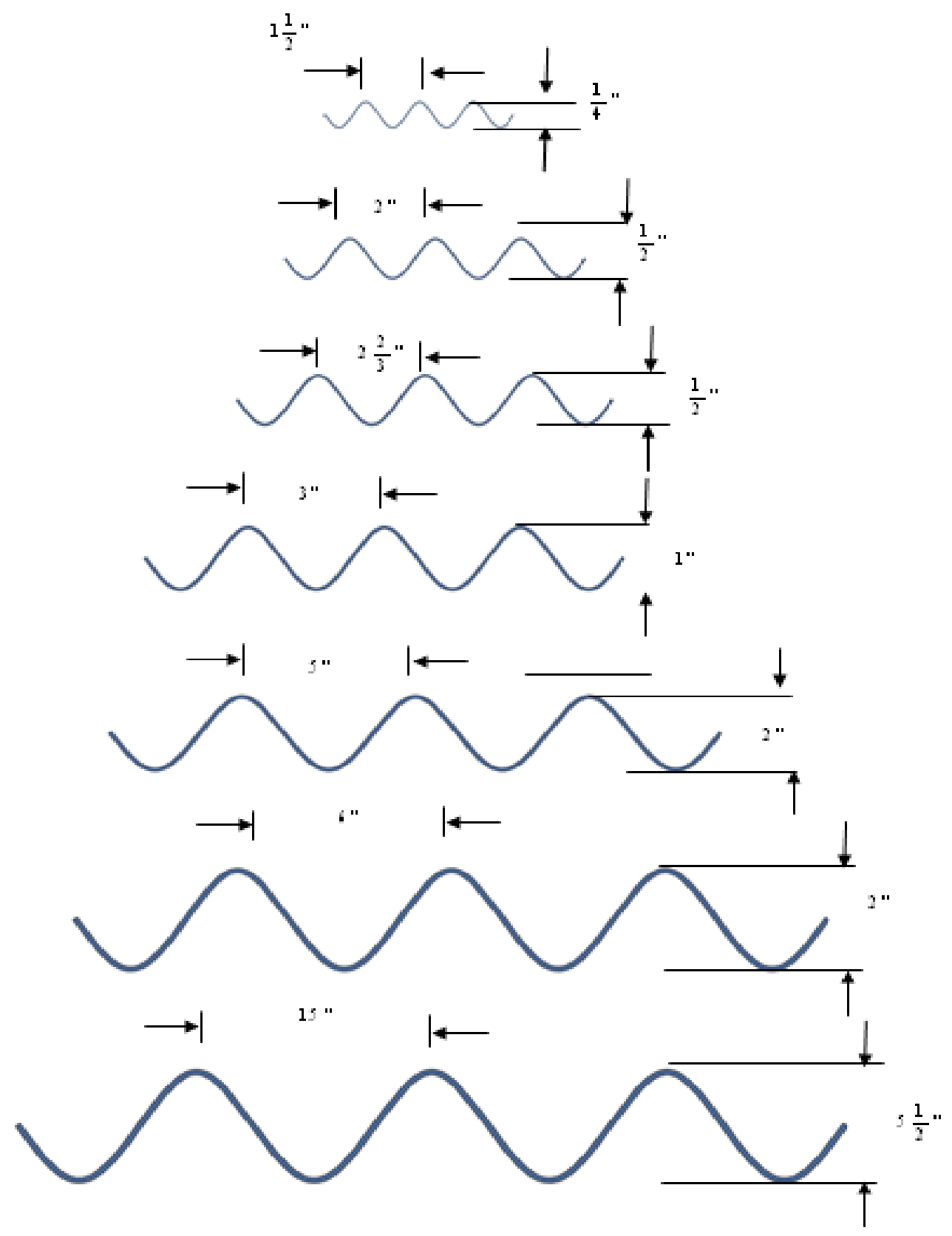

Figure 5.5: Arc and tangent corrugations(NCSPA,2008). 


\subsubsection{Estimation of elastic modulus of corrugated steel pipe with annular seams}

In two dimensional finite element analyses of buried pipes, it is difficult to model geometrical features such as corrugations which may be present on the inside or the outside surface of the circular pipe section. Thus, it is assumed that the pipe has a rectangular cross-section having the same structural stiffness as the corrugated section as shown in Figure 5.6.The method used to model the corrugated annular steel pipes is shown below using a 48 inch pipe whose sectional properties were obtained from Table 5.7:

For a 48-inch nominal pipe diameter:

Corrugation profile dimension (pitch $(\mathrm{p}) \mathrm{x}$ depth $\left(\mathrm{d}_{\mathrm{c}}\right)$ ) $=3$ in. $\mathrm{x} 1$ in

Inside diameter (ID)

Outside diameter (OD)

Moment of inertia $\left(\mathrm{I}_{\mathrm{d}}\right)$

Specified thickness of corrugation $\left(\mathrm{t}_{\mathrm{c}}\right)$

Flexural modulus of the pipe $\left(E_{d}\right)$

$$
=48.00 \mathrm{in} \text {. }
$$$$
=50.104 \mathrm{in} \text {. }
$$$$
=0.0069 \mathrm{in} 4 / \mathrm{in} \text {. }
$$$$
=0.052 \mathrm{in} \text {. }
$$$$
=30,000,000 \mathrm{psi}
$$

Mean diameter $\left(\mathrm{D}_{\text {mean }}\right)=$ Inside diameter $(\mathrm{ID})+\left(\mathrm{t}_{\mathrm{c}}\right)+\mathrm{d}_{\mathrm{c}}$

$$
=48.00+2(0.052)+1=49.052 \text { in. }
$$

Therefore, mean radius $\left(\mathrm{r}_{\text {mean }}\right)=24.526 \mathrm{in}$.

The thickness of the pipe can be calculated as shown below:

$$
\mathrm{t}=\frac{(\mathrm{OD}-\mathrm{ID})}{2}
$$


where

$$
\begin{gathered}
t=\text { thickness of pipe (in) } \\
\text { OD = outside diameter of pipe (in.) } \\
\text { ID = inside diameter of pipe (in.) }
\end{gathered}
$$

Therefore, the thickness for a 48 inch pipe diameter can be calculated by using Equation (5.8) as:

$$
\mathrm{t}=\frac{(50.104-48.00)}{2}=1.052 \mathrm{in}
$$

The obtained value is the thickness used to idealize the cross section of the pipe as a rectangular section. Thus, the moment of inertia can be calculated as:

$$
I_{p}=\frac{t^{3}}{12}=\frac{1.052^{3}}{12}=0.0970 \text { in. }^{4} / \text { in. }
$$

In the above steps, the geometric stiffness has been altered. In order to maintain equilibrium, the material stiffness has to be modified. The alteration is shown below:

$$
E_{d} I_{d}=E_{p} I_{p}
$$

where

$E_{d}=$ Elastic modulus of corrugated section for double-wall pipe.

$\mathrm{E}_{\mathrm{p}}=$ Elastic modulus of idealized rectangular section.

$I_{d}=$ Moment of Inertia of corrugated section for double-wall pipe.

$\mathrm{I}_{\mathrm{p}}=$ Moment of Inertia of idealized rectangular section 
Therefore

$$
\mathrm{E}_{\mathrm{p}}=\frac{\mathrm{E}_{\mathrm{d}} \mathrm{I}_{\mathrm{d}}}{\mathrm{I}_{\mathrm{p}}}=\frac{30,000,000 * 0.0069}{0.097021}=2,133,557.6 \mathrm{psi}
$$



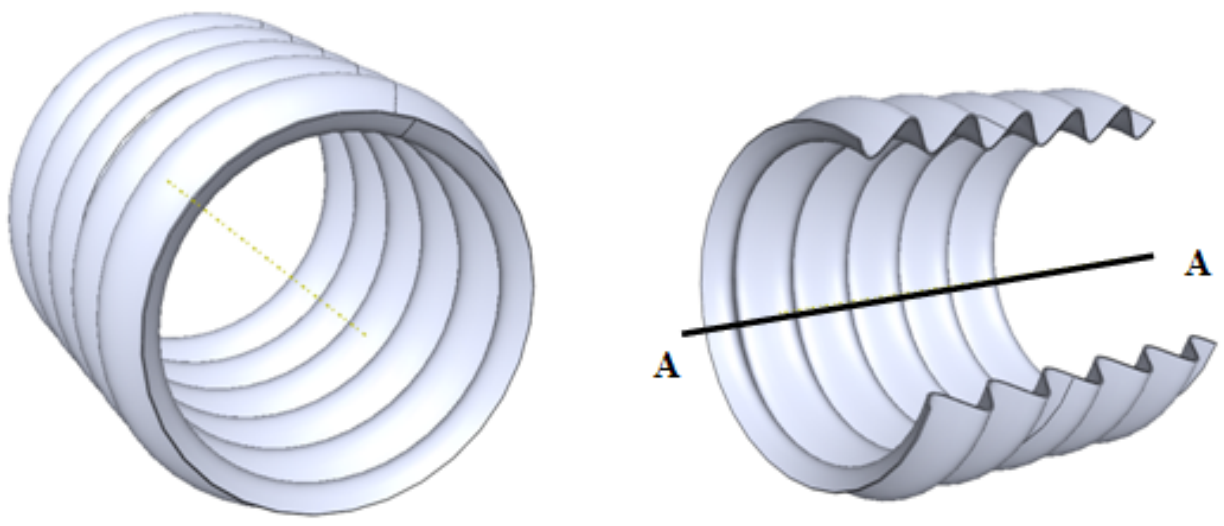

(a) Corrugated steel pipe (annular seams)
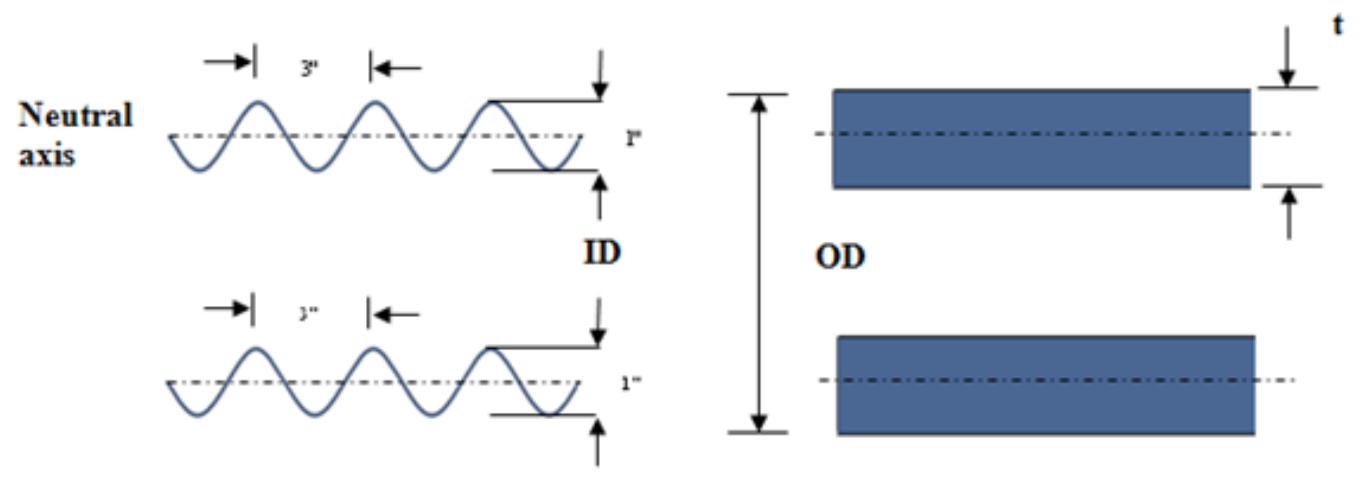

(b) Section A-A of comugated pipe

(c) Idealized section of comugated pipe

Figure 5.6: Typical cross section of corrugated steel pipe with annular seams. 


\subsection{Reinforced concrete pipes (RCP)}

Commercially available concrete pipes offer superior quality products as they are produced under extremely controlled environments, strict manufacturing standards, and testing specifications. Concrete pipes are considered as rigid pipes, and mainly depend on their inherent strength to support external loads. The 28-day compressive strength of concrete is normally in the range of 4,000 psi to 8,000 psi (ACPA, 2010). According to ASTM C 76 which covers the specification for reinforced concrete pipes, the strength of a pipe is expressed by using the D-load (expressed in pounds-force per linear foot per foot of diameter), which is the load required to produce a 0.01 inch crack (ASTM C 76, 2004). Reinforced concrete pipes are divided into four classes based on the D-load as shown in Table 5.8 .

Table 5.8: ASTM C 76 Standards for Reinforced Concrete Pipe

\begin{tabular}{|c|c|}
\hline Class & D-Load(lb/ft/ft) \\
\hline I & 800 \\
\hline II & 1,000 \\
\hline III & 1,350 \\
\hline IV & 2,000 \\
\hline V & 3,000 \\
\hline
\end{tabular}

Concrete pipes are reinforced with precision fabricated steel wire cages which give them additional strength and load carrying capacity when compared to nonreinforced concrete pipes (ACPA, 2010). In a composite structure like reinforced concrete pipe, concrete is designed for compression and reinforcement for tension. Figure 5.7 shows a concrete pipe with steel reinforcement. The reinforcement is used to its intended capacity only in cases where the concrete cracks, which in most cases doesn't occur. It is because concrete pipes are designed to carry loads well within the engineered load. The design life of concrete pipes is in the range of $70-100$ years (ACPA, 2010). They have the ability to survive for a long time without significant deterioration even in 
harsh environments. Some of the advantages of concrete pipes under standard installation practices are listed below (ACPA, 2010):

- Possess high beam strength and can be pushed to proper grade

- Concrete pipe can bridge over uneven bedding without affecting the pipe hydraulics

- Less susceptible to damage during construction

- Maintains shape under external loads

- Smaller fill heights and trench widths can be used

- Lower maintenance, installation, and inspection costs

- Less expensive backfill materials can be used with reduced level of compaction

The ability to maintain structural integrity is the key to long-term performance and efficiency of a material. Since concrete pipes maintain their original shape and alignment they help improve the hydraulic efficiency by minimizing the resistance to water flow. The hydraulic capacity of the pipe is directly proportional to the degree of smoothness of the interior pipe wall. The sectional properties of reinforced concrete pipes are shown in Table 5.9. 


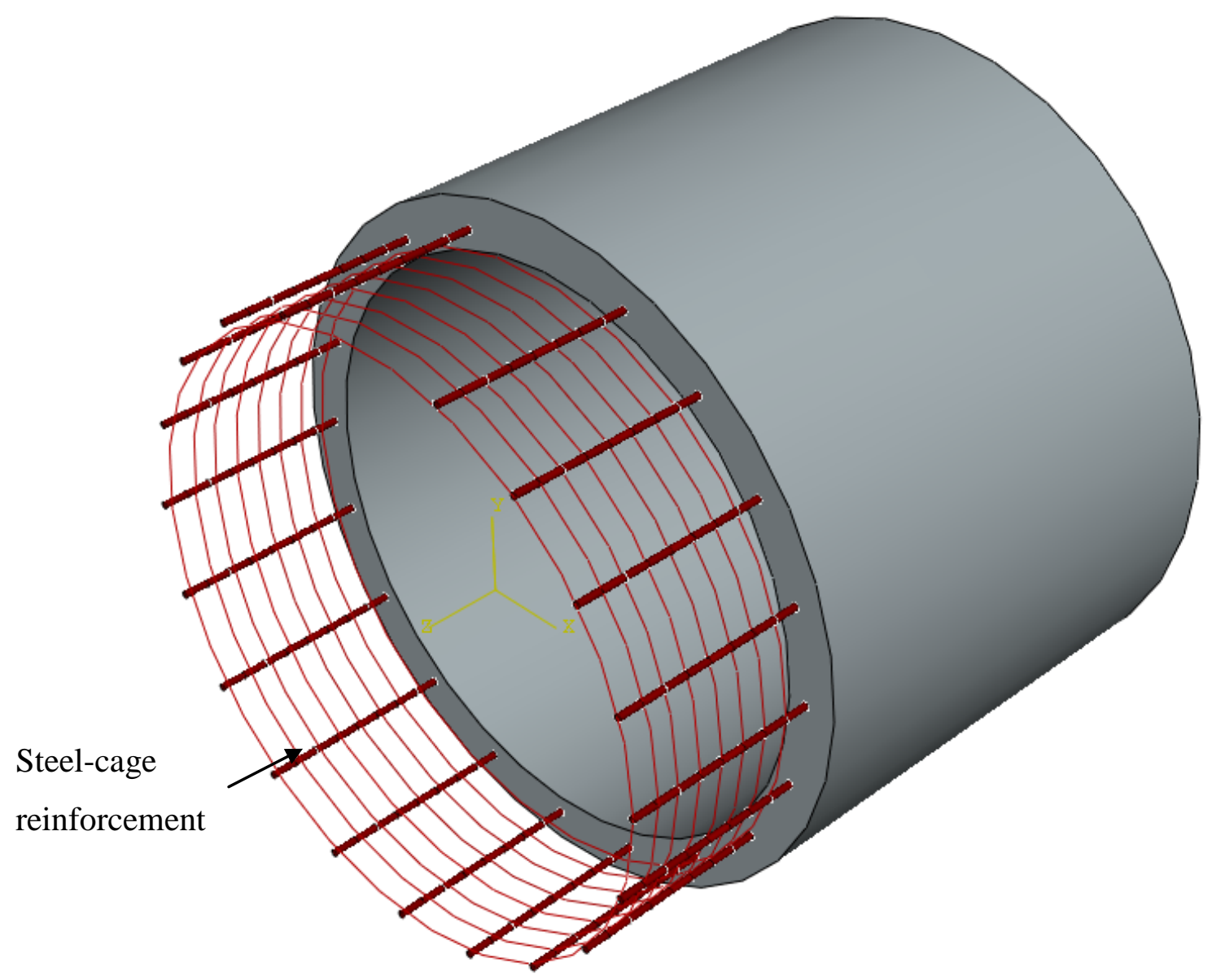

Figure 5.7 Reinforced concrete pipe. 
Table 5.9: Sectional Properties of Class II Reinforced Concrete Pipe (ASTM C-76, 2004)

\begin{tabular}{|c|c|c|c|}
\hline \multirow{3}{*}{$\begin{array}{c}\text { Internal Designated } \\
\text { Diameter(in.) }\end{array}$} & \multicolumn{3}{|c|}{ Wall A- Concrete Strength, 4000 psi } \\
\hline & \multirow{2}{*}{$\begin{array}{c}\text { Wall Thickness } \\
\text { (in.) }\end{array}$} & \multicolumn{2}{|c|}{$\begin{array}{c}\text { Circular Reinforcement } \\
\qquad\left(\mathrm{in}^{2} / \text { /ft) }\right.\end{array}$} \\
\hline & & Inner Cage & Outer Cage \\
\hline 12 & $13 / 4$ & 0.07 & -- \\
\hline 15 & $17 / 8$ & 0.07 & -- \\
\hline 18 & 2 & 0.07 & -- \\
\hline 21 & $21 / 4$ & 0.12 & -- \\
\hline 24 & $21 / 2$ & 0.13 & -- \\
\hline 27 & $25 / 8$ & 0.15 & -- \\
\hline 30 & $23 / 4$ & 0.15 & -- \\
\hline 33 & $27 / 8$ & 0.16 & -- \\
\hline 36 & 3 & 0.14 & 0.08 \\
\hline 42 & $31 / 2$ & 0.16 & 0.10 \\
\hline 48 & 4 & 0.21 & 0.13 \\
\hline 54 & $41 / 2$ & 0.25 & 0.15 \\
\hline 60 & 5 & 0.30 & 0.18 \\
\hline 66 & $51 / 2$ & 0.35 & 0.21 \\
\hline 72 & 6 & 0.41 & 0.25 \\
\hline 78 & $61 / 2$ & 0.46 & 0.28 \\
\hline 84 & 7 & 0.51 & 0.31 \\
\hline 90 & $71 / 2$ & 0.57 & 0.34 \\
\hline 96 & 8 & 0.62 & 0.37 \\
\hline
\end{tabular}




\subsubsection{Estimation of elastic modulus of steel reinforced concrete pipe}

Reinforced concrete pipe is a composite structure consisting of concrete and embedded steel reinforcement (Figure 5.7). In two-dimensional finite element analyses, it is difficult to model steel reinforcement embedded in the concrete pipe section. Thus, a three-dimensional (3D) finite element model was developed to determine the elastic modulus of this composite material. Using 3D solid features, the concrete pipe section was modeled. Steel reinforcement cages were modeled by using beam elements. Threedimensional static analyses were performed on Class II reinforced concrete pipe sections with diameters ranging from 24 inches $(0.60 \mathrm{~m})$ to 72 inches. The sectional properties of these pipe sections which are in accordance with ASTM C-76 are given in Table 5.9. The pipe deflections obtained from these static analyses were used to obtain the pipe stiffness. The elastic modulus of the composite section was derived by using the calculated stiffness value and comparing it with the solution given by classical elastic analyses as given by Equation 2.6. The method used to obtain the elastic modulus of a 24-inch $(0.60$ m) reinforced concrete pipe is shown below:

For a 24-inch $(0.60 \mathrm{~m})$ reinforced concrete pipe

Inside diameter (ID)

Outside diameter (OD)

Wall thickness (t)

Concrete strength

Elastic modulus of concrete $\left(\mathrm{E}_{\text {concrete }}\right)$

Elastic modulus of steel $\left(\mathrm{E}_{\text {steel }}\right)$

Circumferential Reinforcement Area

Mean diameter $\left(\mathrm{D}_{\text {mean }}\right)=$ Inside diameter $(\mathrm{ID})+(\mathrm{t})$

$$
=24.00+(2.5)=26.50 \mathrm{in} .
$$

Therefore, mean radius $(\mathrm{r})=13.25 \mathrm{in}$.

$$
\begin{aligned}
& =24.00 \mathrm{in} .(600 \mathrm{~mm}) \\
& =29 \cdot 00 \mathrm{in} .(725 \mathrm{~mm}) \\
& =2.50 \mathrm{in} .(62.5 \mathrm{~mm}) \\
& =4,000 \mathrm{psi} \\
& =3,644,147 \mathrm{psi} \\
& =30,000,000 \mathrm{psi} \\
& =0.13 \mathrm{in}^{2} / \mathrm{ft}
\end{aligned}
$$


From the static analyses for a vertical load (F) of $100 \mathrm{lb} / \mathrm{in}$, the deflection $(\Delta \mathrm{Y})$ obtained from the finite element analysis was 0.0066 in. Using the following relationship, the elastic modulus of reinforced concrete pipe was obtained.

Pipe Stiffness $(P S)=\frac{F}{\Delta Y}=\frac{E I}{0.149 r^{3}}$

$$
=\frac{100}{0.0066}=\frac{\mathrm{E} * 1.302}{0.149 *(13.25)^{3}}
$$

$\mathrm{E}=\frac{0.149 *(13.25)^{3} * 100}{0.00663 * 1.302}=4,033,471 \mathrm{psi}$

The same procedure was used for the remaining pipe sections and a summary of results is presented in Table 5.11. An elastic modulus of 4,033,471 psi is used for reinforced concrete pipes in this research study in order to be conservative.

Table 5.10: Elastic Modulus Values Obtained from 3D Static Analyses

\begin{tabular}{|c|c|}
\hline Diameter(inches) & $\begin{array}{c}\text { Elastic Modulus } \\
\text { psi (MPa) }\end{array}$ \\
\hline 24 & $4,033,471(27,809.81)$ \\
\hline 36 & $7,147,445(49,279.91)$ \\
\hline 48 & $5,602,469(38,627.67)$ \\
\hline 60 & $7,166,020(49,407.98)$ \\
\hline 72 & $12,921,828(89,092.89)$ \\
\hline
\end{tabular}




\section{Chapter 6: NUMERICAL METHODOLOGY}

\subsection{Introduction}

In the last few decades, finite element method (FEM) has found its application in many areas of civil engineering. It has been used to obtain solutions for field related problems with different complexities including non-linear problems (Watkins and Anderson, 1999). The ability to solve complex problems in a short period gives finite element techniques an edge over experimental work, which usually involves a lot of expenditure and time. In this research work, the time-dependant behavior of flexible and rigid pipes was analyzed by using a commercially available software package (ABAQUS, 2007). This chapter deals with the methodology used in developing a time dependent soil-pipe model.

\subsection{Basic principles of finite element analysis}

In the finite element method, a continuum is discretized into finite number of elements which are connected at the nodal points. The finite elements and the nodal points make up a grid called a mesh. Polynomial interpolations are used to denote the displacement compatibility between adjacent elements and relate the displacement field along the element boundary and the nodes (Cook et al, 2003). The elemental equations generated from the discretization of the continuum are used to obtain an approximate solution. The assembly of elemental equations so obtained is used to develop the governing equations which are written in matrix form as (Cook et al, 2003):

$$
[\mathrm{K}][\mathrm{D}]=[\mathrm{Q}]
$$

Where

$[\mathrm{K}]=$ Global stiffness matrix

[D] = Nodal displacement vector 
$[\mathrm{Q}]=$ Nodal load vector

The derivation of the global equilibrium equations is given elsewhere (Cook et al, 2003). Using these equations, unknown nodal displacements, stresses, and strains in an element can be calculated. Elements of the global stiffness matrix are a function of structural geometry, dimensions, elastic properties, and shape function (Cook et al, 2003). In two-dimensional (2D) finite element analysis, the symmetry of the continuum offers an advantage since less number of nodes is required to represent it. The analysis becomes easier since less number of equations have to be solved (Cook et al, 2003).

\subsection{Finite elements used in this study}

In the finite element method, the procedure for analyzing soil-structure interaction problems associated with buried pipes is different when compared to a simple linear elastic continuum (Gondle and Siriwardane, 2008). Consideration is given to various parameters such as the stress-strain characteristics of the soil system, geometry of the structure, selection of an appropriate element type to represent the soil-structure, and applicability of an interface element. A two-noded linear beam element (B21) was used to model the pipe geometry. The soil was modeled by using four-noded bilinear plane strain quadrilateral (CPE4R) elements (ABAQUS, 2007; Cook et al, 2003). In the past, finite element analyses were performed on unconfined rings to select an appropriate element type to model the pipe geometry (Gondle and Siriwardane, 2008). Beam elements were preferred over plane strain elements since the latter could not accommodate shear and bending moments (Gondle and Siriwardane, 2008).

The beam element consists of two nodes, one at each end (Figure 6.1). Each node consists of two degrees of freedom which govern the spatial variation of the field, namely lateral translation (r) and rotation ( $\varphi$ ). A schematic of a beam element and its nodal degrees of freedom are shown in Figure 6.1 (a). Figure 6.1 (b) shows the loads at each node associated with the nodal degree of freedom. Detailed mathematical formulation of 
the beam element can be found elsewhere (Cook et al., 2003). A two-dimensional bilinear quadrilateral consists of nodes at each corner of the quadrilateral. It is a four-noded element with eight degrees of freedom (Cook et al, 2003). Figure 6.2 shows a typical bilinear quadrilateral and its eight degree of freedom. Figure 6.3 shows the isoparametric bilinear quadratic element in the physical space. In isoparametric elements, a shape function is used to interpolate both coordinates and displacements of a point within the element from the coordinates and displacements of nodes (Cook et al, 2003). Detailed mathematical formulation of isoparametric bilinear quadratic elements can be found elsewhere (Cook et al., 2003).

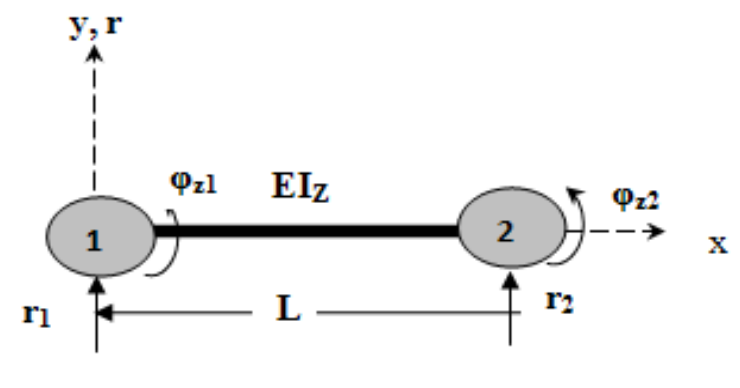

(a)

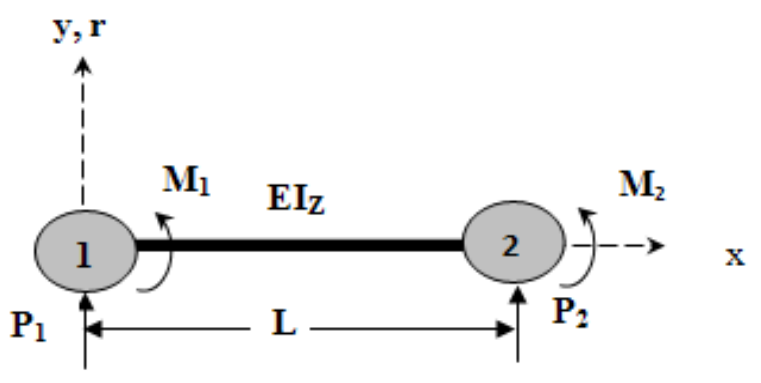

(b)

(a) Beam element in the xy plane and its nodal degrees of freedom. (b) Nodal loads associated with nodal degrees of freedom.

Figure 6.1: Two-noded beam element (Cook et al, 2003).

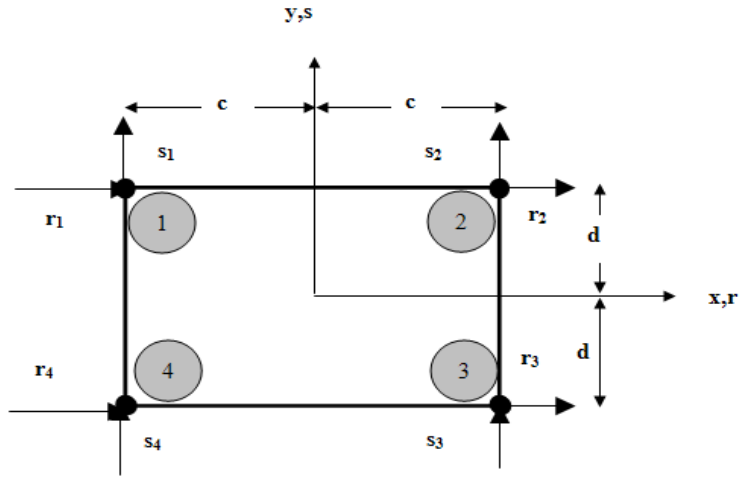

Figure 6.2: Bilinear quadrilateral (Cook et al, 2003). 


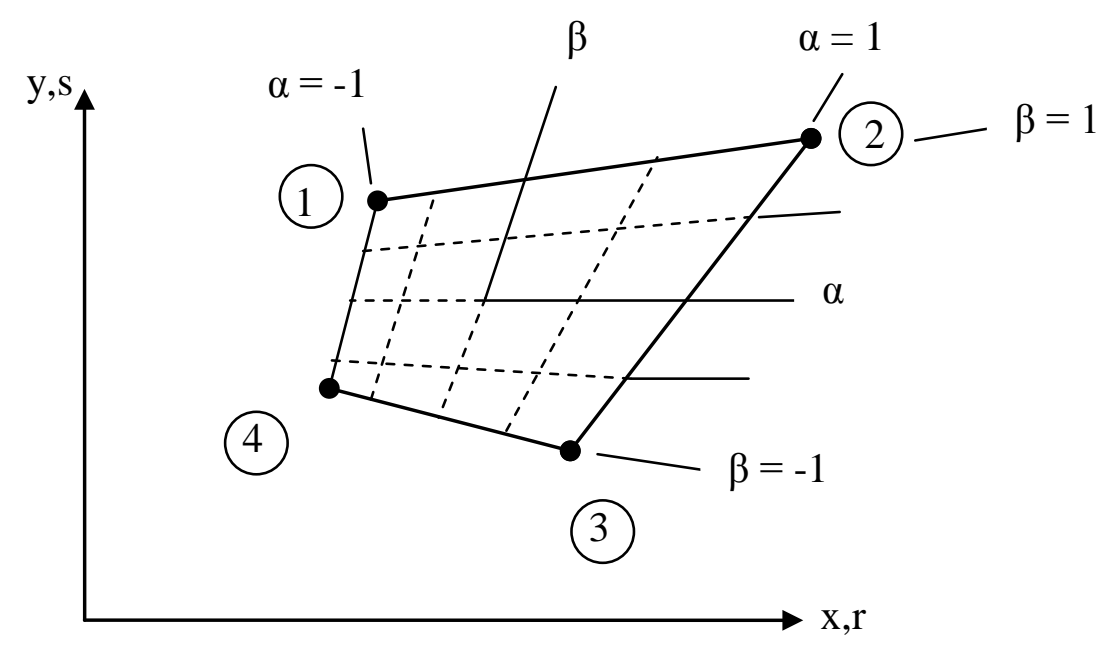

(a) Global coordinate system

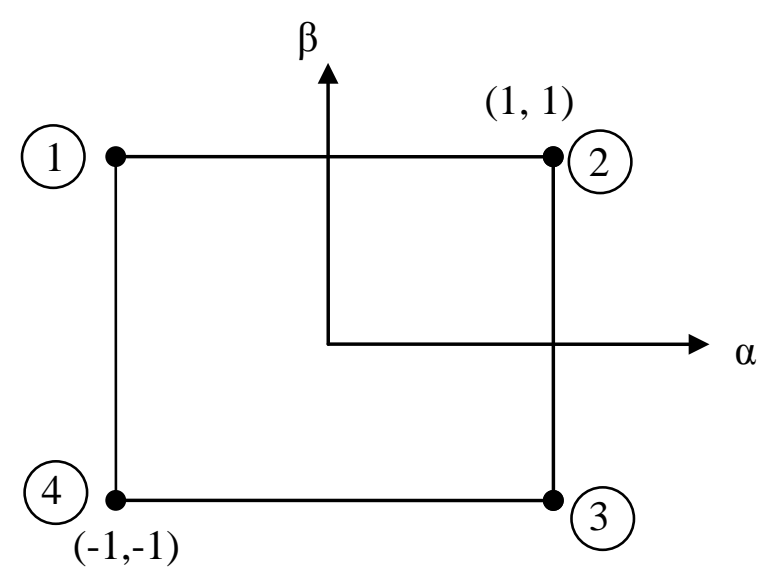

(b) Local coordinate system

Figure 6.3:Isoparametric bilinear quadrilateral (Desai and Abel, 1972;Gondle and Siriwardane,2008). 


\subsection{Loading, boundary conditions and finite element step sequence}

Two loading conditions were used in this study - (a) the self-weight of the soil (dead load) and (b) combination of the HS-25 loading at the ground surface (live load) and the self-weight of the soil (dead load). HS-25 loading of magnitude 100 psi (689.5 $\left.\mathrm{kN} / \mathrm{m}^{2}\right)$ was applied on a rectangular strip of 20 inch $(0.5 \mathrm{~m}) \times 10$ inch $(0.25 \mathrm{~m})$ at the ground surface (AASHTO, 2007). Figure 6.4 shows the HS-25 load distribution. Figure 6.5 shows the boundary conditions applied to the trench geometry. In the finite element model, a tie constraint was used to connect the pipe elements with the surrounding soil elements so that both soil and the pipe act as a composite structure (ABAQUS, 2007; Gondle and Siriwardane, 2008).

\section{HS 25 TRUCK LOAD}

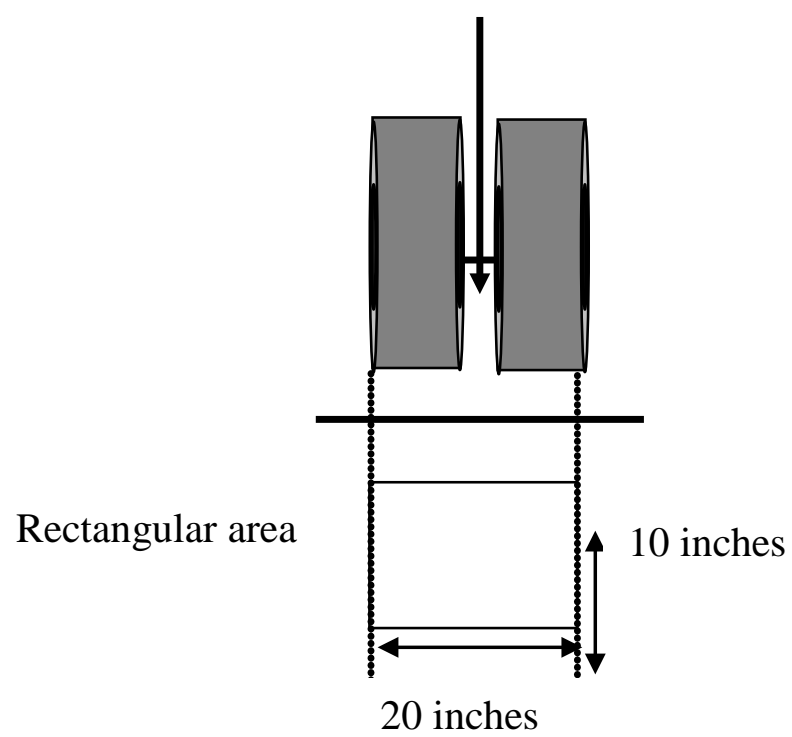

Figure 6.4: HS-25 load distribution.

In the time-dependent creep analyses, several steps have been defined to analyze the pipe-soil model for a period of fifty years. The creep analysis starts with the application of an instantaneous load after which the pipe is allowed to creep for a period 
of fifty years in subsequent steps. The fifty-year analysis was divided into six steps as given below:

Step 1: Instantaneous application of the load.

Step 2: Pipe was allowed to creep for a period of one hour at regular time intervals of three minutes.

Step 3: Pipe was allowed to creep for a period of one day (24 hours) at regular intervals of one hour.

Step 4: Pipe was allowed to creep for a period of one year (8,760 hours) at regular intervals of one day (24 hours).

Step 5: Pipe was allowed to creep for a period of five years $(43,800$ hours) at regular intervals of five days (120 hours).

Step 6: Pipe was allowed to creep for a period of fifty years (438,000 hours) at regular intervals of fifty days (1,200 hours). 


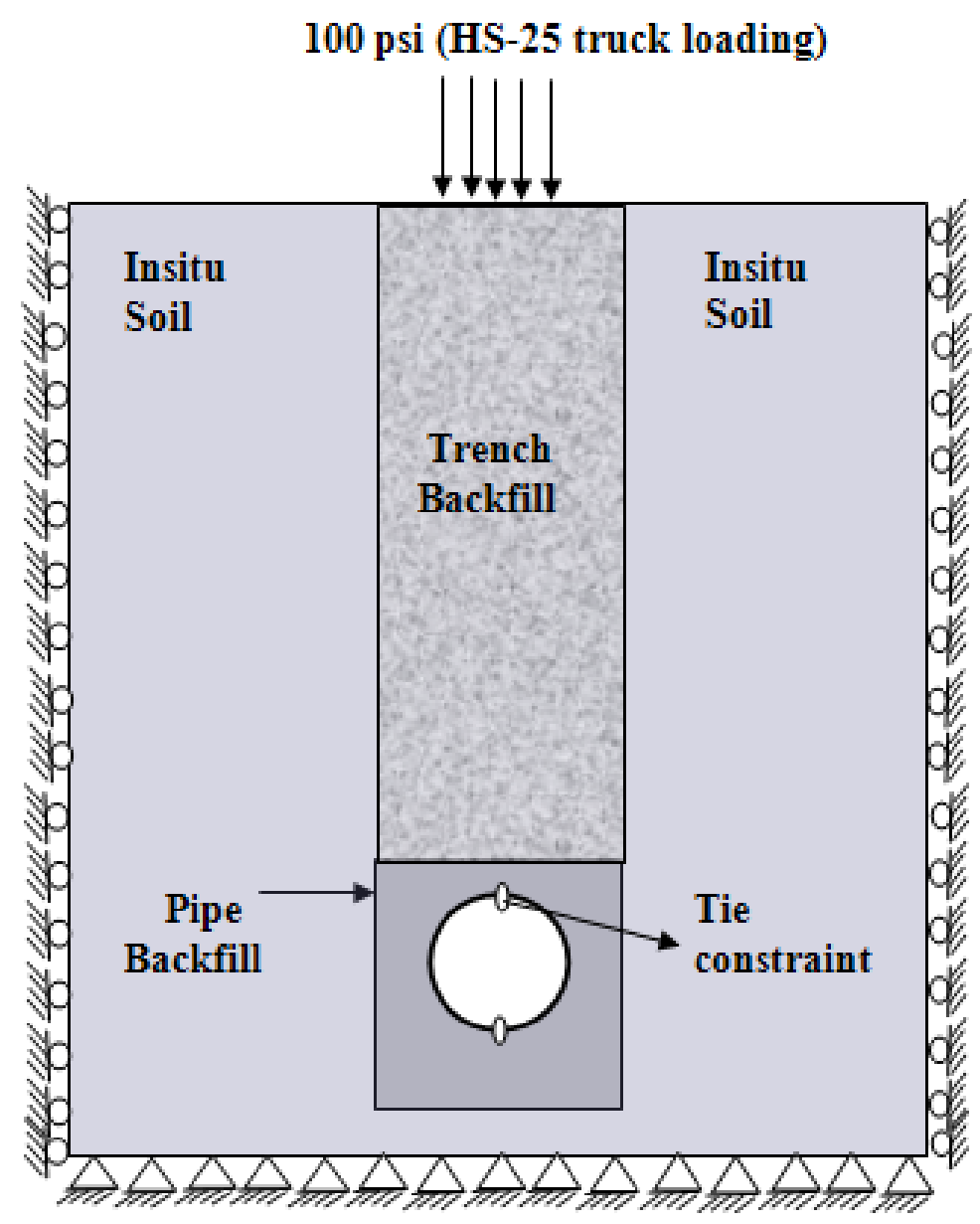

Figure 6.5: Boundary conditions of the soil-pipe system. 


\subsection{Material properties}

In the finite element model, three soil sections with different properties were considered: trench backfill, pipe backfill, and insitu soil as shown in Figure 6.6. Soil and pipe material properties used in the study are presented in Table 6.1 and Table 6.2, respectively.

100 psi (HS-25 truck loading)

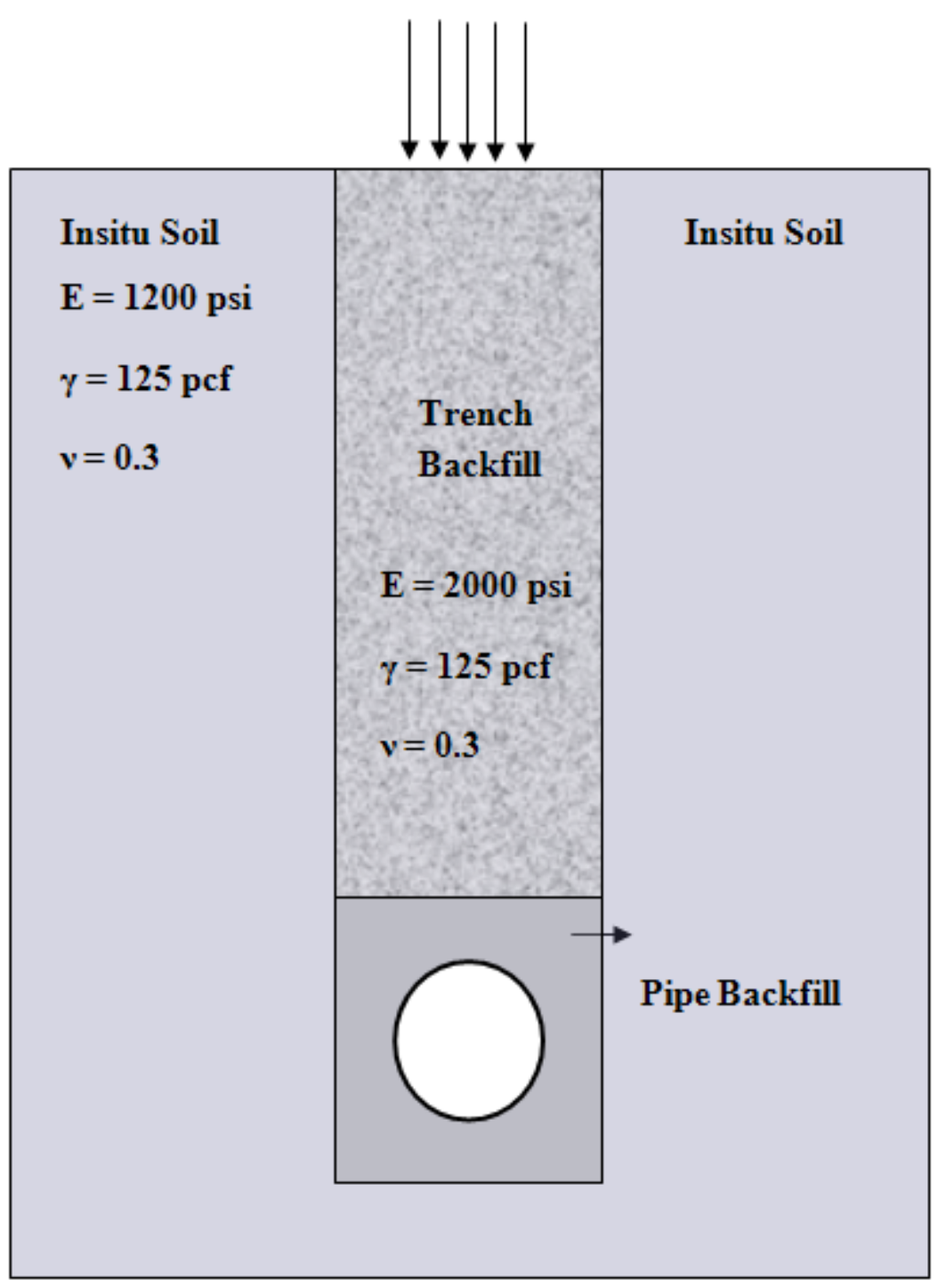

Figure 6.6: Soil properties used in the finite element analyses. 
Table 6.1: Soil Properties

\begin{tabular}{|c|c|c|c|c|}
\hline $\begin{array}{c}\text { Property/ } \\
\text { Material }\end{array}$ & $\begin{array}{c}\text { Final } \\
\text { Backfill soil }\end{array}$ & Insitu soil & $\begin{array}{c}\text { Pipe } \\
\text { Backfill(CLSM) }\end{array}$ & $\begin{array}{c}\text { Granular } \\
\text { Stone Pipe } \\
\text { Backfill }\end{array}$ \\
\hline $\begin{array}{c}\text { Elastic Modulus, E } \\
\text { psi (MPa) }\end{array}$ & $2,000(13.78)$ & $1,200(8.27)$ & $5,000(34.47)$ & $3,000(20.68)$ \\
\hline Poisson's ratio, $\mathbf{v}$ & 0.30 & 0.30 & 0.30 & 0.30 \\
\hline $\begin{array}{c}\text { Mass density, } \boldsymbol{\rho} \\
\mathbf{p c f}\left(\mathbf{k g} / \mathbf{m}^{\mathbf{3}}\right)\end{array}$ & $125(2,002)$ & $125(2,002)$ & $140(2,243)$ & $146(2,339)$ \\
\hline
\end{tabular}

Table 6.2: Pipe Properties

\begin{tabular}{|c|c|c|c|c|}
\hline $\begin{array}{c}\text { Property/ } \\
\text { Material }\end{array}$ & HDPE & PVC & RCP & CSP \\
\hline $\begin{array}{c}\text { Elastic Modulus, E } \\
\text { psi } \\
\text { (MPa) }\end{array}$ & $\begin{array}{c}110,000 \\
(758.42)\end{array}$ & $\begin{array}{c}400,000 \\
(2,757.90)\end{array}$ & $\begin{array}{c}4,033,471 \\
(27,809.81)\end{array}$ & $\begin{array}{c}30,000,000 \\
(2,068,42.77)\end{array}$ \\
\hline $\begin{array}{c}\text { Poisson's ratio, } \mathbf{v} \\
\text { Mass density, } \boldsymbol{\rho}\end{array}$ & 0.46 & 0.41 & 0.20 & 0.30 \\
\hline $\mathbf{p c f}\left(\mathbf{k g} / \mathbf{m}^{\mathbf{3}}\right)$ & $60(961)$ & $86(1,378)$ & $145(2,323)$ & $490(7,849)$ \\
\hline
\end{tabular}




\subsection{Creep formulation in finite element method}

Time dependent elastic modulus $\mathrm{E}_{\mathrm{t}}$, is one of the important parameters required to model the creep behavior of buried pipes. Several creep models are available in ABAQUS, out of which the power law model is the most convenient to use (Arvidsson and Gronvall, 2004; ABAQUS, 2007). There are two versions of hardening available with the power law model. They are the time- hardening law and the strain- hardening law. The time-hardening law is convenient to use when the stress in the material remains constant, whereas the strain-hardening law is used under fluctuating loads (Arvidsson and Gronvall, 2004; ABAQUS, 2007). In this study, the time hardening law was used. The time-hardening creep law can be described in terms of creep strain rate which is a function of deviatoric stress $(\sigma)$ and time $(t)$ as shown below (ABAQUS, 2007):

$$
\dot{\varepsilon}^{\mathrm{cr}}=A \sigma^{\mathrm{m}} \mathrm{t}^{\mathrm{n}}
$$

Where

$\dot{\varepsilon}^{\mathrm{Cr}}=$ creep strain rate

$\mathrm{A}=$ determines the level of overall creep deformation

$\mathrm{m}=$ changes in the curvature of the curve

$\mathrm{n}=$ describes how the creep rate depends on stress level

Table 6.3 shows the limits of $\mathrm{A}, \mathrm{n}$ and $\mathrm{m}$ in order to avoid numerical difficulties (Arvidsson and Gronvall, 2004).

Table 6.3: Values of $A$, $n$ a nd $m$ (Arvidsson and Gronvall, 2004; A BAQUS, 2007; Gondle and Siriwardane, 2008)

\begin{tabular}{|c|c|}
\hline Creep parameters & Range \\
\hline $\mathrm{A}$ & $>10^{-27}$ \\
\hline $\mathrm{n}$ & $>0$ \\
\hline $\mathrm{m}$ & $-1<\mathrm{m}<0$ \\
\hline
\end{tabular}


In the following section, creep constants are determined for HDPE, PVC and concrete material by using a back calculation procedure (Gondle and Siriwardane 2008) to the time-hardening power law model.

\subsubsection{High density polyethylene (HDPE)}

The creep constants for HDPE can be calculated as shown below. Equation (4.12) can be expressed as given below:

$\varepsilon(t)=\frac{\sigma}{E(t)}=\frac{\sigma}{67,779 t^{-0.0859}}=\left(\frac{1}{67,779}\right) \sigma^{(1)} t^{0.0859}$

Therefore, the creep strain rate can be obtained as below:

$$
\begin{aligned}
\dot{\varepsilon}(t) & =\frac{d \varepsilon(t)}{d t}=\left(\frac{1}{67,779} \times 0.0859\right) \sigma^{(1)} t^{0.0859-1} \\
& =\left(1.267354 \times 10^{-6}\right) \sigma^{(1)} t^{-0.9141}
\end{aligned}
$$

\subsubsection{Polyvinyl chloride (PVC)}

The creep constants for PVC can be calculated as shown below. Equation (4.13) can be expressed as given below:

$$
\varepsilon(t)=\frac{\sigma}{E(t)}=\frac{\sigma}{3,94,043 t^{-0.0567}}=\left(\frac{1}{3,94,043}\right) \sigma^{(1)} t^{0.0567}
$$

Therefore, the creep strain rate can be obtained as below: 


$$
\begin{aligned}
\dot{\varepsilon}(t) & =\frac{d \varepsilon(t)}{d t}=\left(\frac{1}{3,94,038} \times 0.0567\right) \sigma^{(1)} t^{0.0567-1} \\
& =\left(1.44 \times 10^{-7}\right) \sigma^{(1)} \mathrm{t}^{-0.9433}
\end{aligned}
$$

\subsubsection{Concrete}

The creep constants for concrete can be calculated as shown below. Equation (4.14) can be expressed as given below:

$$
\varepsilon(t)=\frac{\sigma}{E(t)}=\frac{\sigma}{5,812,337.3586 t^{-0.0714}}=\left(\frac{1}{5,812,337.3596}\right) \sigma^{(1)} t^{0.0714}
$$

Therefore, the creep strain rate can be obtained as below:

$$
\begin{aligned}
\dot{\varepsilon}(t)=\frac{d \varepsilon(t)}{d t} & =\left(\frac{1}{5,812,337.3596} \times 0.0714\right) \sigma^{(1)} t^{0.0714-1} \\
& =\left(1.228 \times 10^{-8}\right) \sigma^{(1)} \mathrm{t}^{-0.9286}
\end{aligned}
$$

Table 6.4 shows the constants used to model time dependent nature of pipe using the time hardening creep law in this study.

Table 6.4: Creep Parameters of Pipe Materials

\begin{tabular}{|c|c|c|c|}
\hline Material & $\mathbf{A}$ & $\mathbf{n}$ & $\mathbf{m}$ \\
\hline HDPE & $1.26735 \mathrm{e}-06$ & 1 & -0.9141 \\
\hline PVC & $1.44 \mathrm{e}-07$ & 1 & -0.9433 \\
\hline Concrete & $1.228 \mathrm{e}-08$ & 1 & -0.9286 \\
\hline
\end{tabular}




\section{Chapter 7: RESULTS AND DISCUSSIONS}

\subsection{Introduction}

In the present study, two-dimensional finite element analyses were performed to evaluate the long-term performance of double-wall corrugated HDPE, solid-wall PVC, reinforced concrete and corrugated steel pipes. Analyses were performed on pipe diameters ranging between 18 inches $(0.45 \mathrm{~m})$ and 120 inches $(3 \mathrm{~m})$ for a period of 50 years. Since no creep parameters have been reported for corrugated steel pipes under low temperature conditions (i.e., room temperatures), only static analyses were performed. The influence of CLSM and granular stone pipe backfill on the pipe behavior was also investigated. In the creep analyses, backfill heights ranging from 10 feet $(3 \mathrm{~m})$ to 50 feet (15 m) were considered. In this study, two loading conditions were considered: (a) selfweight of the soil (dead load), and (b) self-weight of the soil and HS-25 loading at the ground surface (dead load and live load). The influence of trench width ratios varying from 1.5 to 2.5 was also investigated. The ratio of the trench width to the nominal diameter of the pipe is defined as trench width ratio. Table 7.1 presents the details of this research work.

Table 7.1 Details of this Study

\begin{tabular}{|c|c|c|c|c|}
\hline Pipe & Profile type & $\begin{array}{c}\text { Diameter } \\
\text { inches } \\
\text { (m) }\end{array}$ & $\begin{array}{c}\text { Trench } \\
\text { width } \\
\text { ratio }\end{array}$ & $\begin{array}{c}\text { Range of fill } \\
\text { height } \\
\text { feet }\end{array}$ \\
\hline $\begin{array}{c}\text { High Density } \\
\text { Polyethylene } \\
\text { (HDPE) }\end{array}$ & Double-wall corrugated & $\begin{array}{c}24-60 \\
(0.60-1.50)\end{array}$ & $1.5-2.5$ & $10-50$ \\
\hline $\begin{array}{c}\text { Polyvinyl } \\
\text { Chloride (PVC) }\end{array}$ & Solid-wall & $\begin{array}{c}18-24 \\
(0.45-0.60)\end{array}$ & $1.5-2.5$ & $10-50$ \\
\hline $\begin{array}{c}\text { Reinforced } \\
\text { Concrete (RCP) }\end{array}$ & -- & $24-108$ & $1.5-2.5$ & $10-50$ \\
\hline $\begin{array}{c}\text { Corrugated Steel } \\
\text { (CSP) }\end{array}$ & Corrugated & $48-120$ & $1.5-2.5$ & $10-50$ \\
\hline
\end{tabular}




\subsection{Numerical results for high density polyethylene (HDPE) pipes}

Analyses were performed on double-wall corrugated high density polyethylene pipes (HDPE) of diameter 24 inch $(0.60 \mathrm{~m}), 36$ inch $(0.90 \mathrm{~m}), 48$ inch $(1.20 \mathrm{~m})$ and 60 inches $(1.50 \mathrm{~m})$. The largest diameter of commercially available double-wall HDPE pipes is 60 inches $(1.5 \mathrm{~m})$. Backfill heights of 10 feet $(3 \mathrm{~m}), 20$ feet $(6 \mathrm{~m})$ and 50 feet $(15 \mathrm{~m})$ were considered. In this section, results obtained for a 60 inch $(1.50 \mathrm{~m})$ pipe are presented since it appears to be the worst-case scenario. A comparison of the performance of other pipe sizes is then presented.

\subsubsection{Response due to self-weight of the soil}

The computed response of a 60-inch $(1.50 \mathrm{~m})$ double-wall corrugated HDPE pipe under self-weight of soil, different trench widths, and backfill materials (CLSM and granular stone pipe backfill) are presented in this section. Figure 7.1 shows the fifty-year deformation contours of the pipe-soil system under self-weight of soil. In this case, the depth of backfill is 20 feet $(6 \mathrm{~m})$ with CLSM as the pipe backfill. Figure 7.2 shows the fifty-year vertical deflections (expressed as a \%) of the pipe installed in CLSM and granular stone. The pipe is installed at a depth of 50 feet $(15 \mathrm{~m})$ in a trench width equal to two times the mean diameter of the pipe. The pipe deflections were computed by taking the difference between the magnitudes of vertical displacement at the crown and base of the pipe.

Figure 7.2 shows a comparison of pipe deflections under different pipe backfill materials. A gradual increase in the pipe deflection over time can be seen. Figure 7.2 also shows that beyond one year of installation the creep deflection was just $20 \%-40 \%$ of the total deflection. Pipe deflection is higher when granular stone is used as pipe backfill. With an increase in backfill height, the vertical pipe deflection increased as shown in Figures 7.3 and 7.4. The influence of trench width can be seen in Figure 7.5 and Figure 7.6 under CLSM and granular stone pipe backfill, respectively. With an increase in trench width, pipe deflections decreased. Also, Figures 7.5 and 7.6 show that a 60 inch $(1.50 \mathrm{~m})$ 
double-wall corrugated HDPE pipe can be installed up to a depth of 50 feet $(15 \mathrm{~m})$ with the trench width ratio as small as 1.5 without causing a pipe failure. The pipe failure criterion of 5\% was used in this study as discussed in Chapter 2.
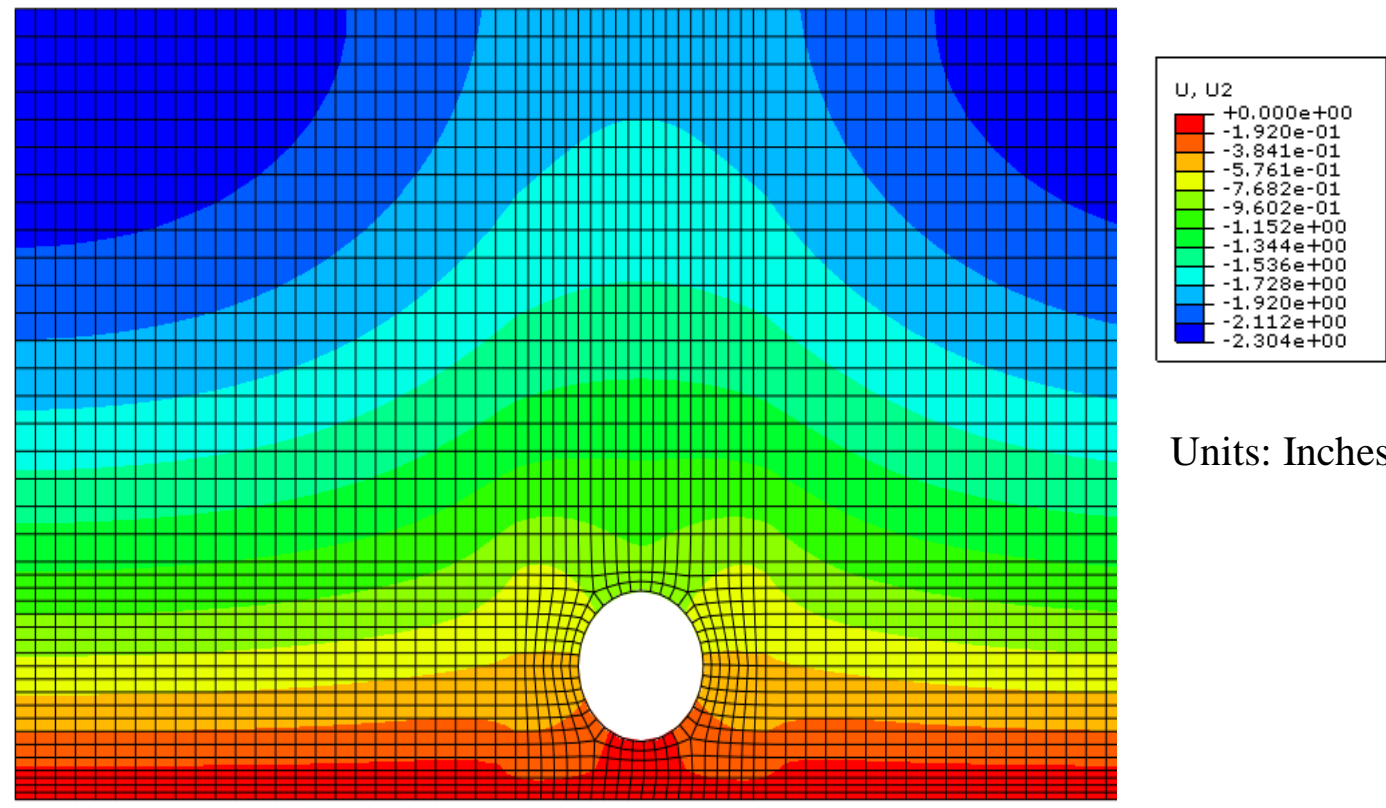

Units: Inches

Figure 7.1: Fifty-year deformation in the soil-pipe system due to self-weight of the soil. 


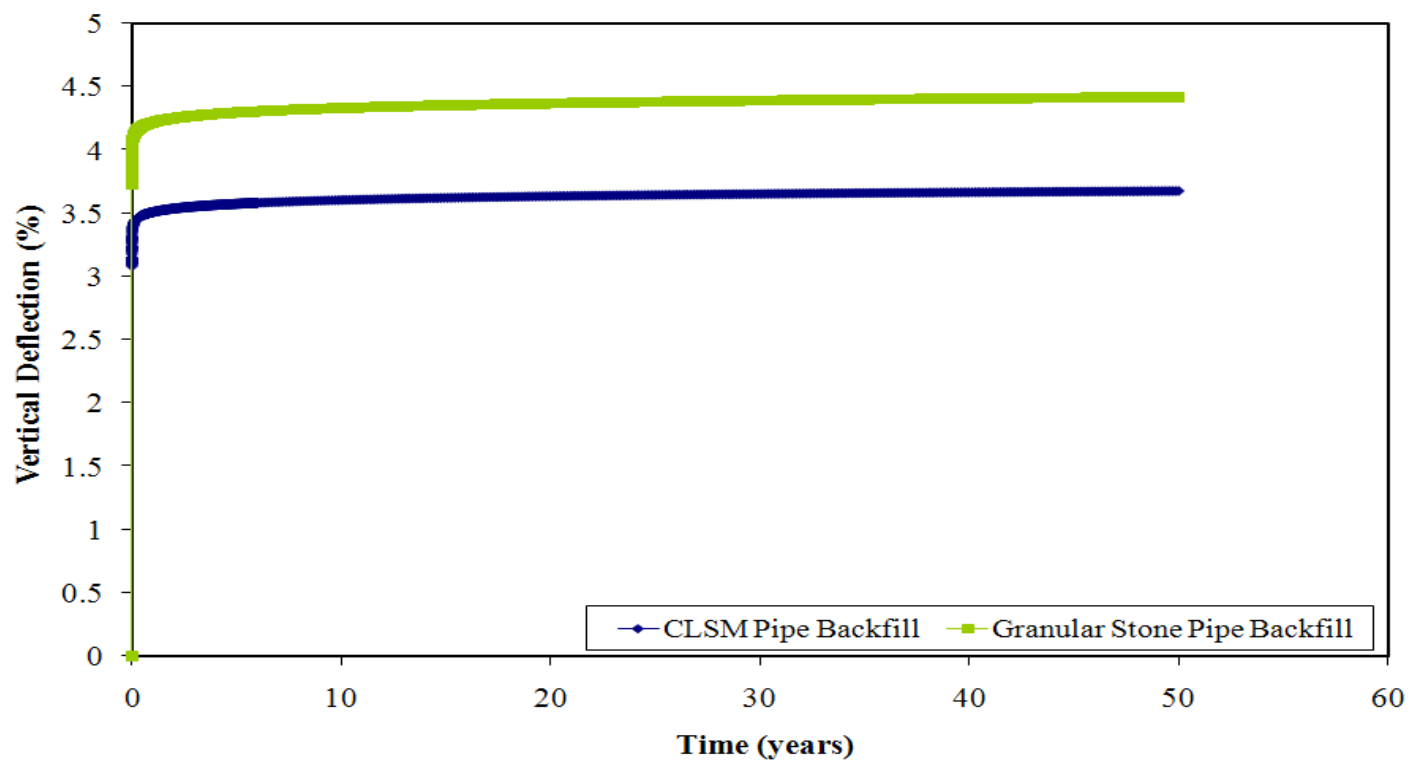

Figure 7.2: Fifty-year vertical deflection of a 60 inch $(1.50 \mathrm{~m})$ HDPE pipe installed at a depth of 50 feet. 


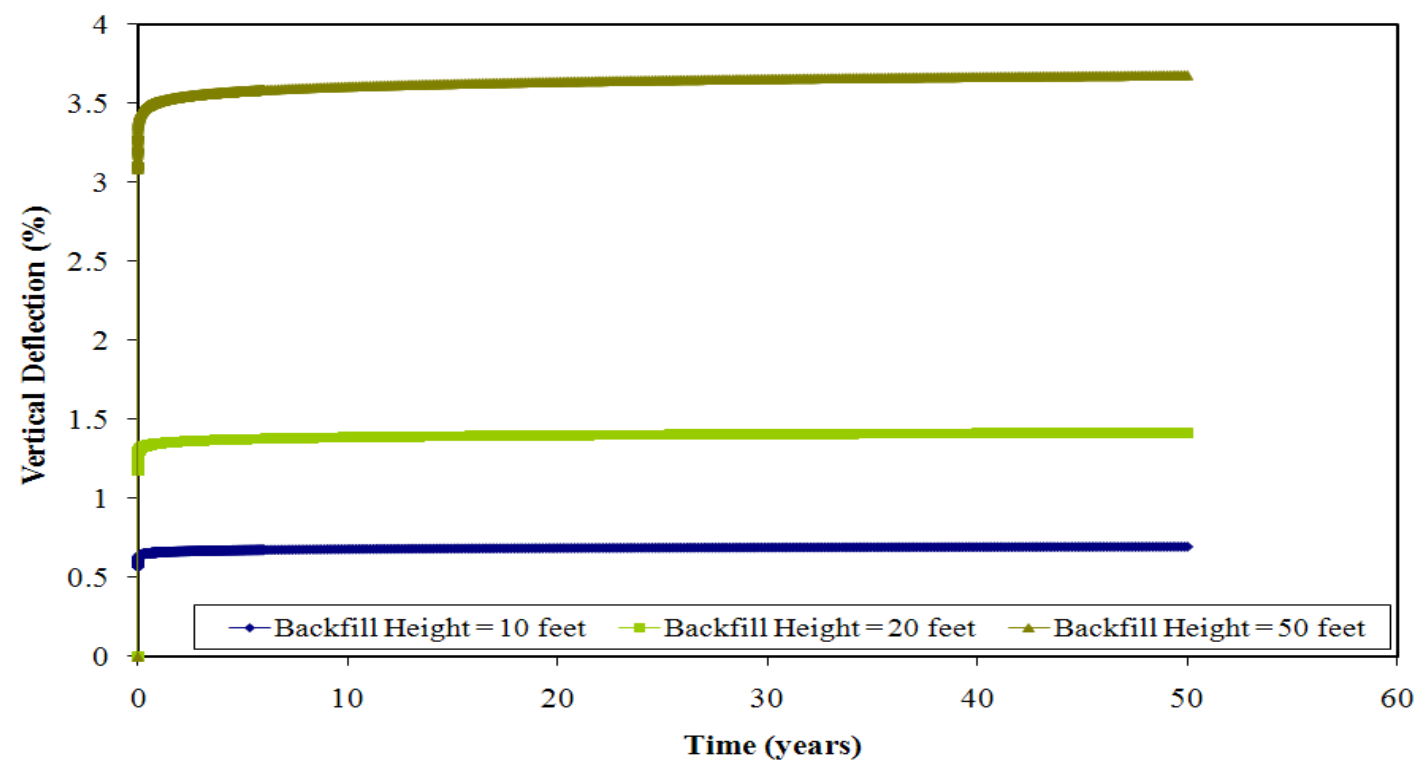

Figure 7.3: Vertical deflections of a 60 inch $(1.50 \mathrm{~m})$ HDPE pipe installed in CLSM under increasing backfill heights.

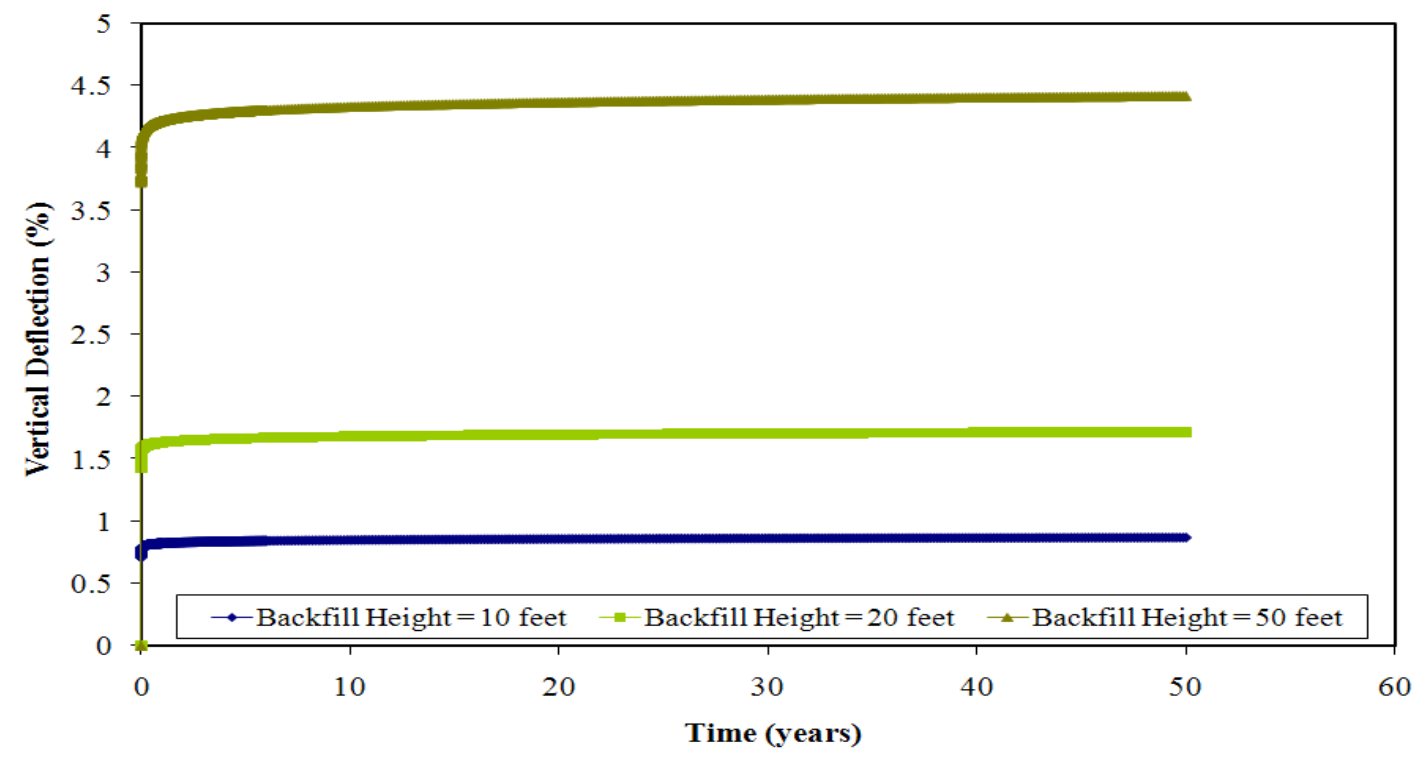

Figure 7.4: Vertical deflections of a $60 \mathrm{i}$ nch $(1.50 \mathrm{~m})$ HDPE pipe installed in granular stone under increasing backfill heights. 


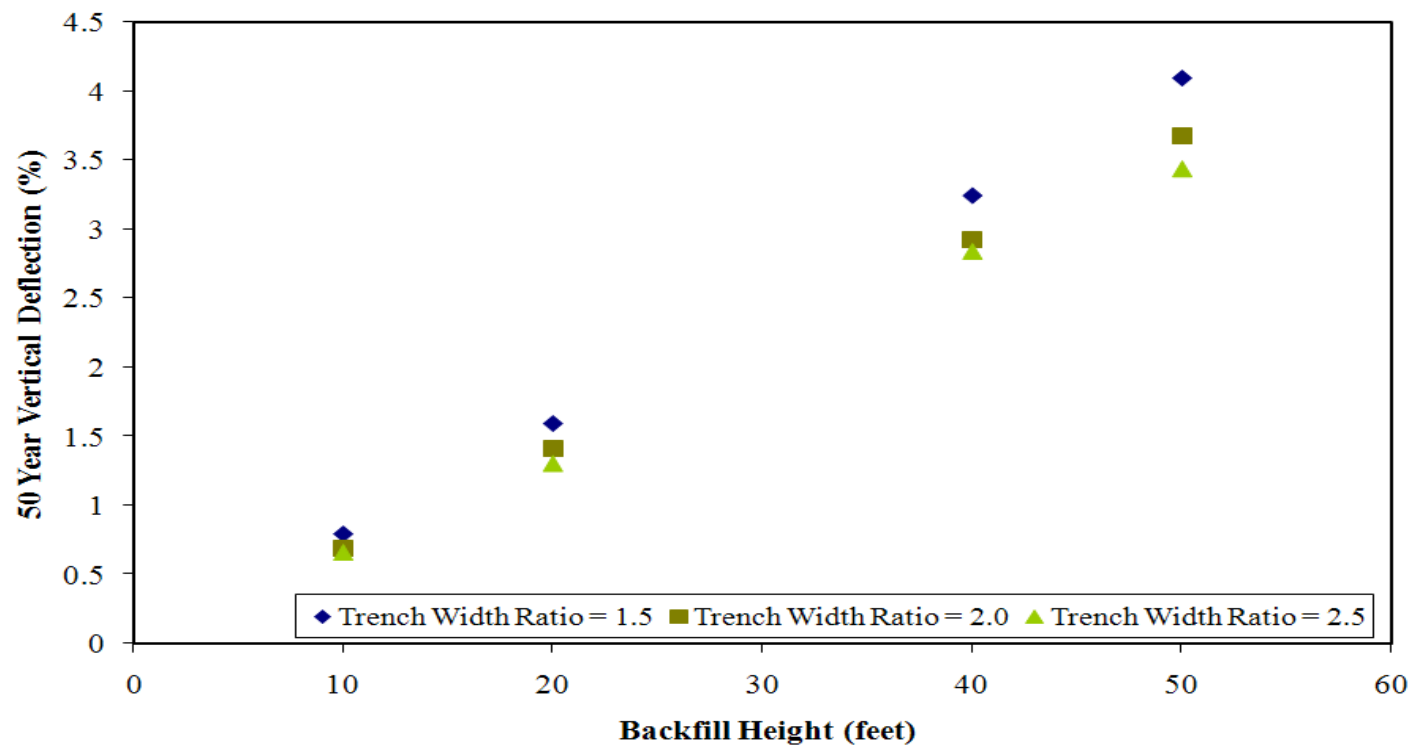

Figure 7.5: Effect of trench width ratio of a 60 inch $(1.50 \mathrm{~m})$ HDPE pipe installed in CLSM.

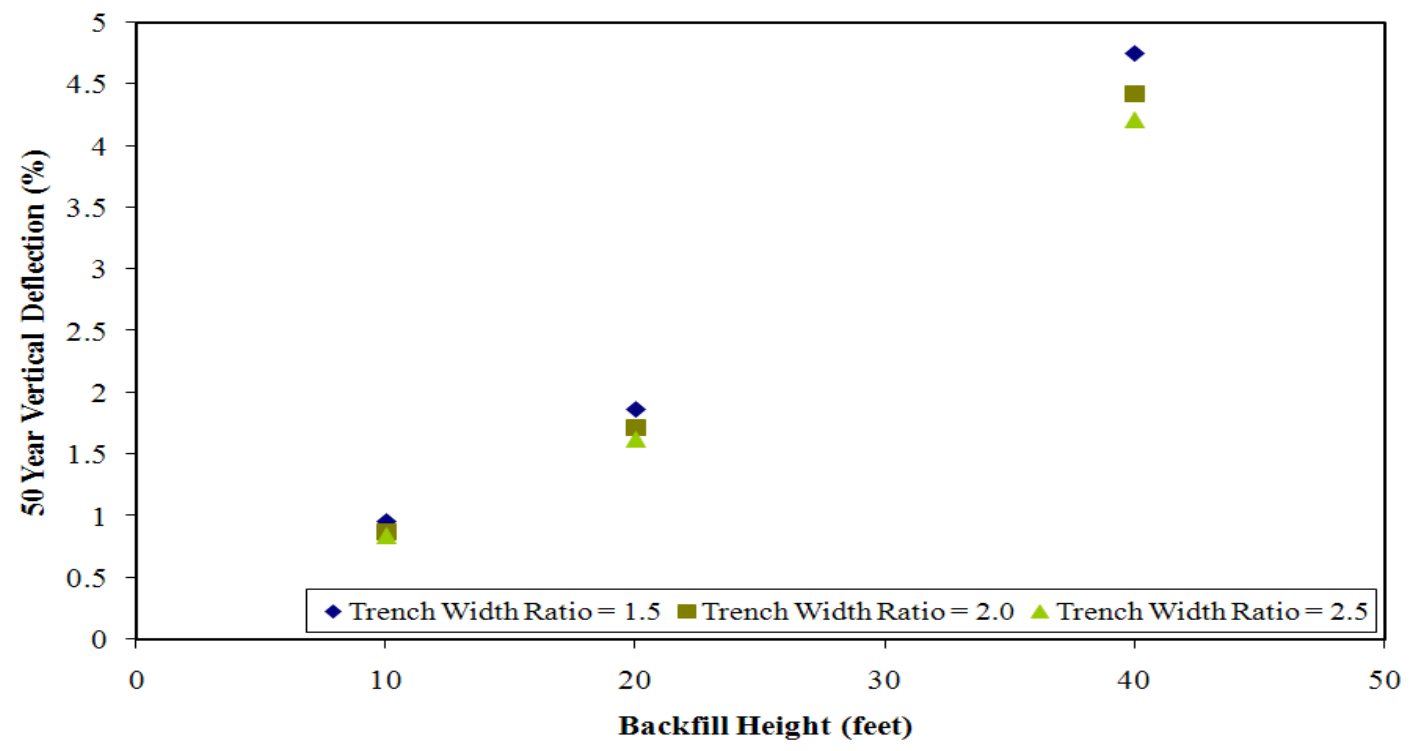

Figure 7.6: Effect of trench width ratio of a 60 inch $(1.50 \mathrm{~m})$ HDPE pipe installed in granular stone. 
The deformation of pipes with various diameters installed under different fill heights and CLSM backfill material are shown in Figure 7.7. The deformation of pipes with various diameters installed under different fill heights and granular stone backfill material are shown in Figure 7.8. The trench width in these cases is equal to two times the mean diameter of the pipe. Results show that the deformation trend is similar for all pipe diameters. The vertical deformations were higher when granular stone was used as pipe backfill, which is similar to what was presented earlier.

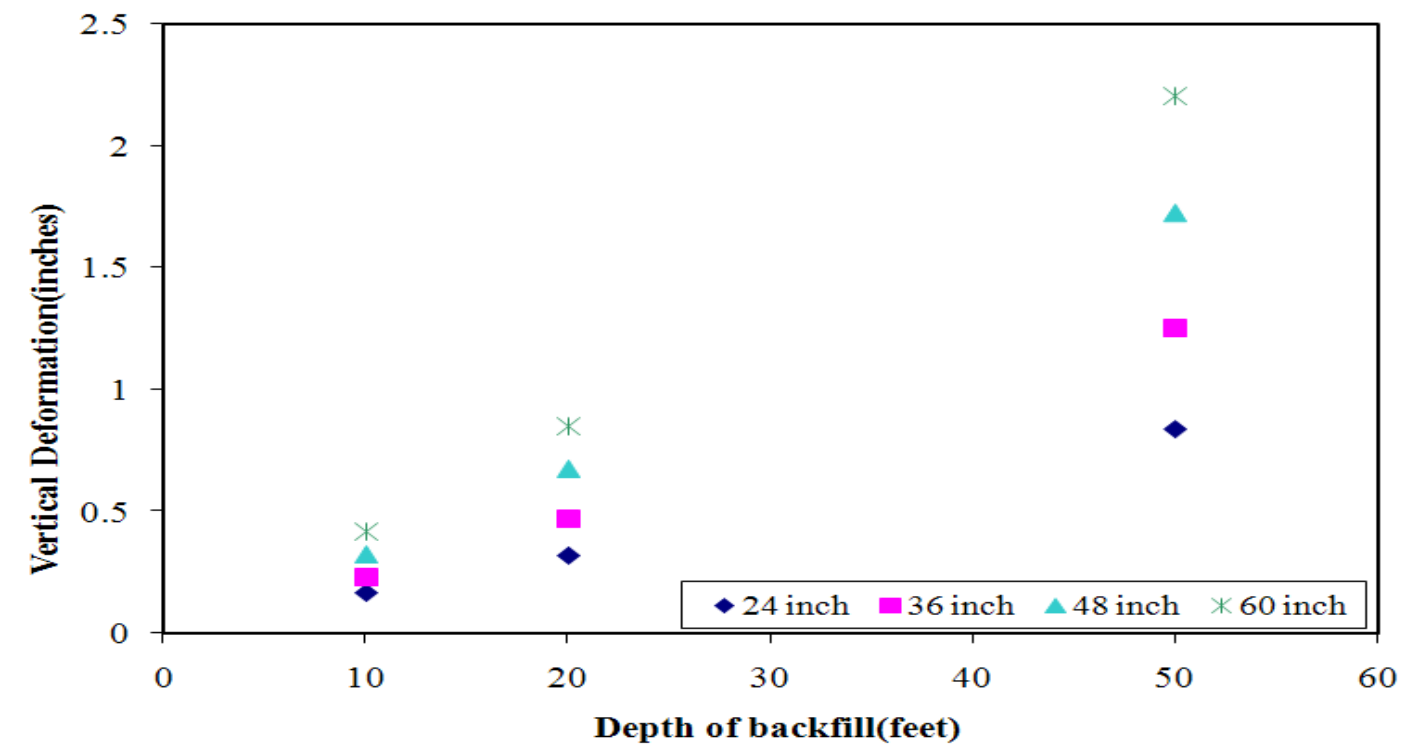

Figure 7.7:Fifty-year vertical deformation of various HDPE pipe diameters installed in CLSM pipe backfill. 


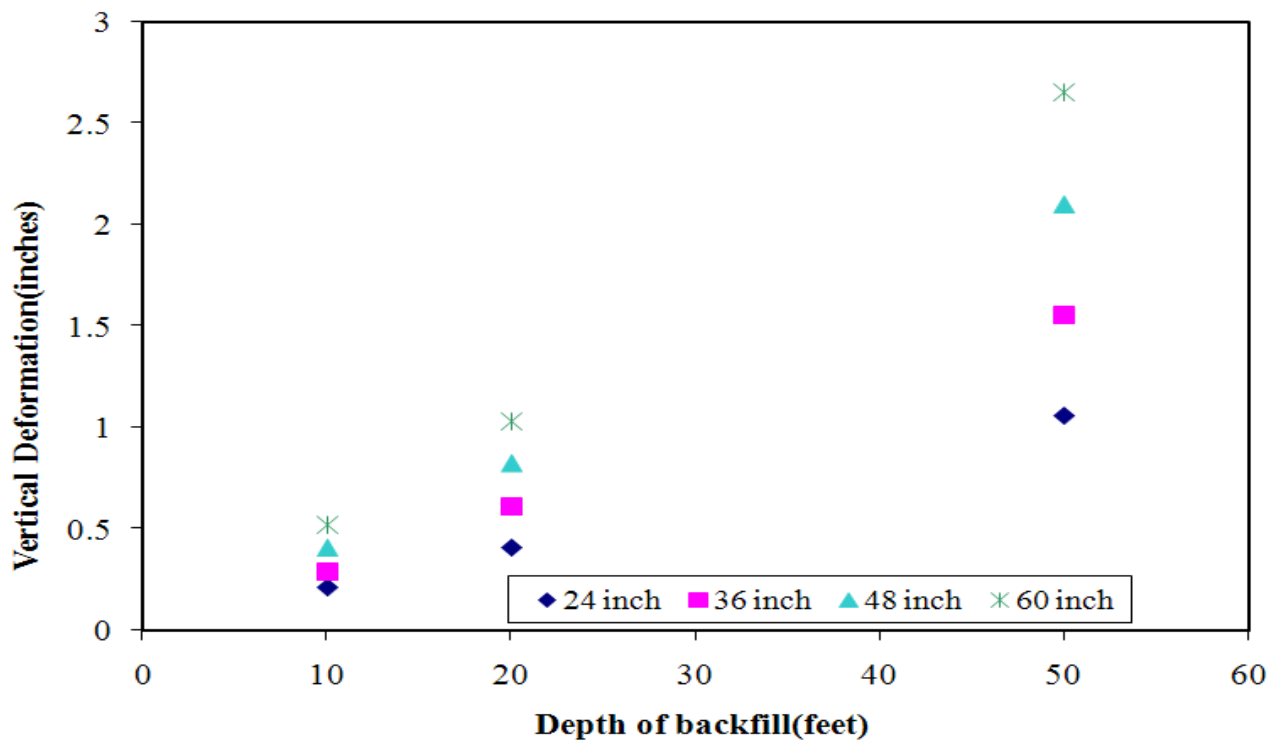

Figure 7.8:Fifty-year vertical deformation of various HDPE pipe diameters installed in granular stone pipe backfill. 


\subsubsection{Response due to HS -25 truck loading + self-weight of the soil}

Figure 7.9 shows the fifty year-deformation contours of the pipe-soil system under self-weight of soil and HS-25 truck loading. The depth of backfill is 20 feet $(6 \mathrm{~m})$ with CLSM as the pipe backfill. Figure 7.10 shows the fifty-year vertical pipe deflections of a 60 inch $(1.50 \mathrm{~m})$ double-wall corrugated HDPE pipe installed in CLSM and granular stone. The pipe is installed at a depth of 50 feet in a trench width equal to two times the mean diameter of the pipe. The loads considered in this case are HS-25 truck loading and the self-weight of the soil .The pipe deflections were computed by taking the difference between the magnitudes of vertical displacement at the crown and base of the pipe.

Figure 7.10 shows a comparison of pipe deflections under CLSM and granular stone pipe backfill materials. A gradual increase in the pipe deflection over time can be seen. Figure 7.10 also shows that beyond one year of installation the creep deformation was just $20 \%$ - $40 \%$ of the total deflection. Also, the percentage deflection values were higher when granular stone was used as pipe backfill. With an increase in backfill height, the vertical pipe deflection increased as shown in Figure 7.11 and Figure 7.12. The influence of trench width can be seen in Figure 7.13 and Figure 7.14 under CLSM and granular stone pipe backfill, respectively. With an increase in trench width the pipe deflections decreased. Also, Figure 7.13 and Figure 7.14 illustrate that a 60 inch $(1.50$ m) double-wall corrugated HDPE pipes can be installed up to a depth of 20 feet $(6 \mathrm{~m})$ with the trench width ratio as small as 1.5.without causing pipe failure. 

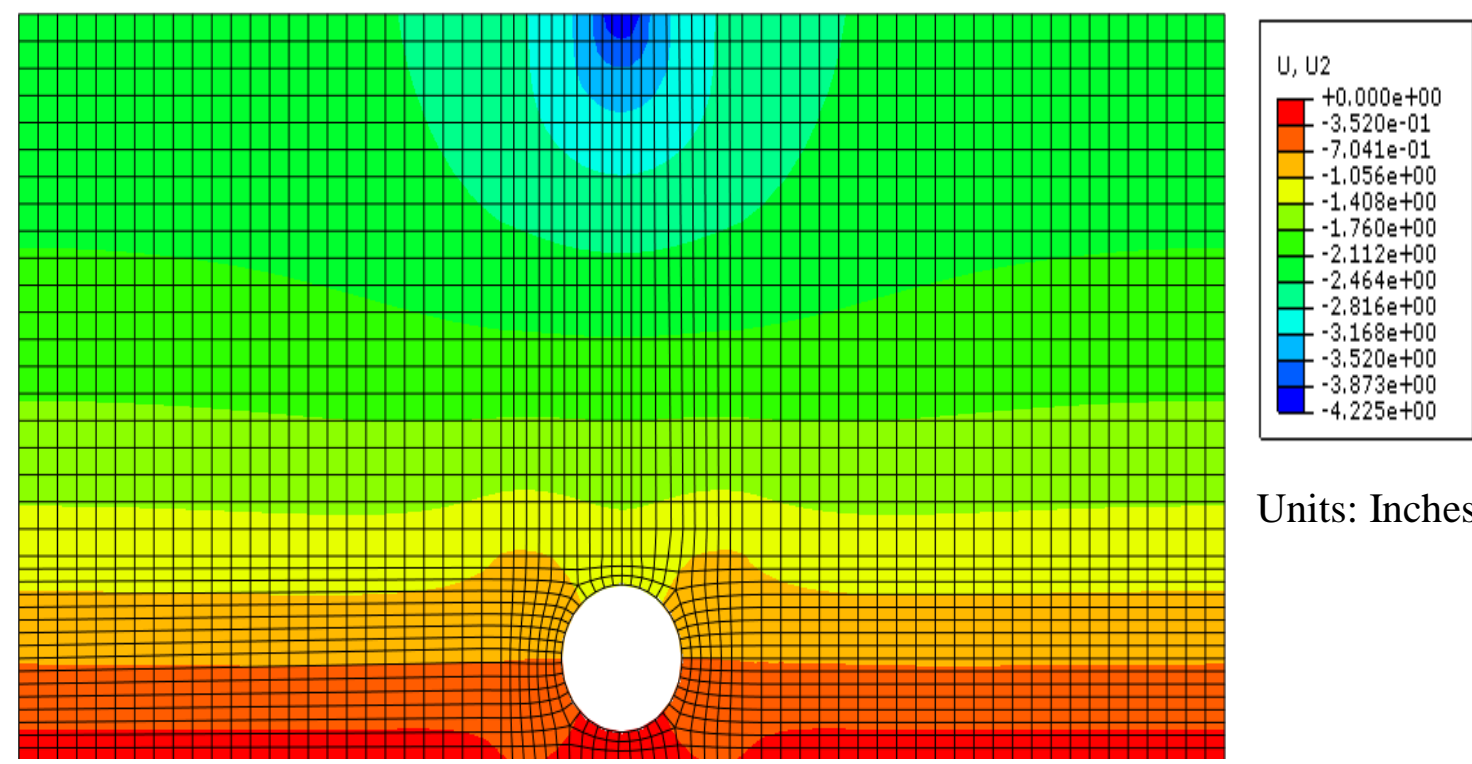

Units: Inches

Figure 7.9: Fifty-year deformation in the soil-pipe system under HS-25 truck loading.

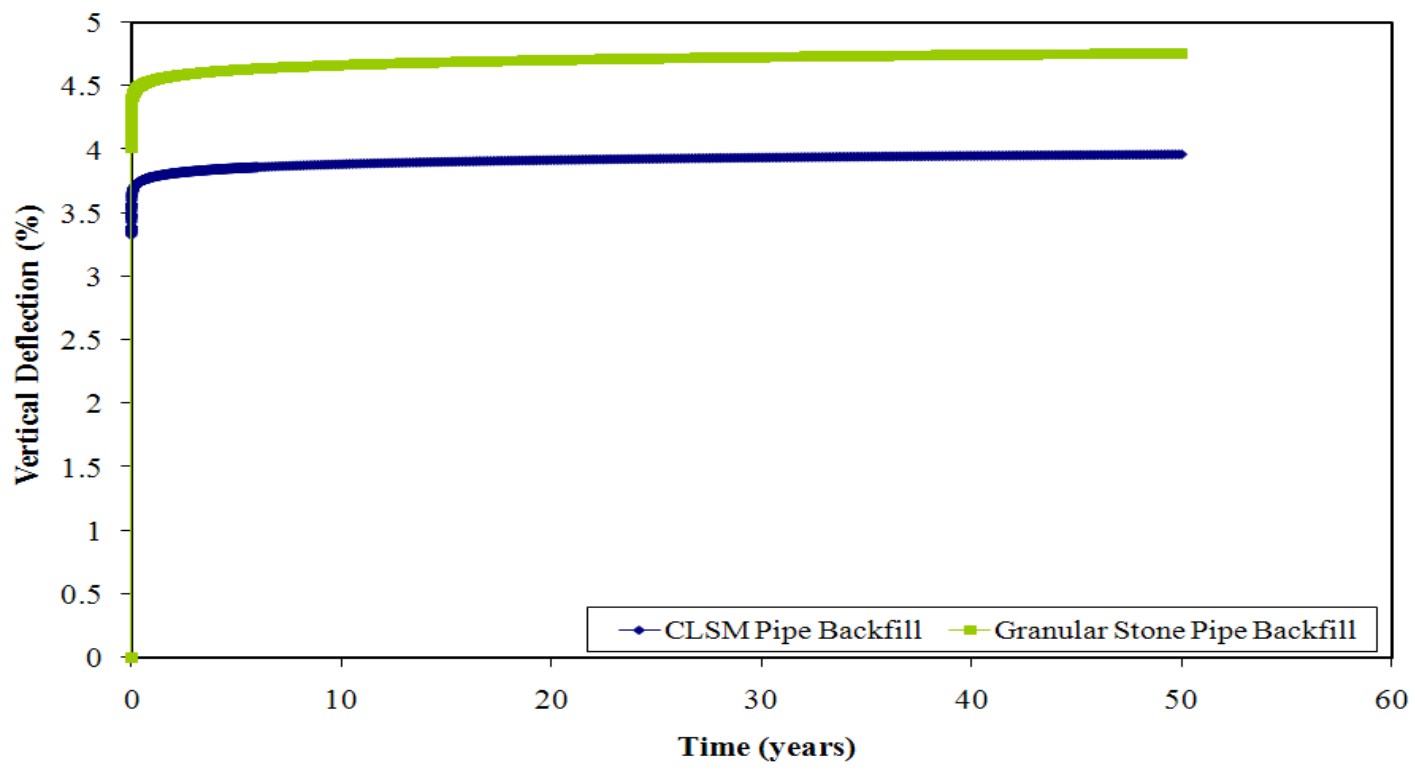

Figure 7.10: Fifty-year vertical deflection of a 60 inch $(1.50 \mathrm{~m}) \mathrm{HDPE}$ pipe due to HS25 loading and self-weight of soil. 


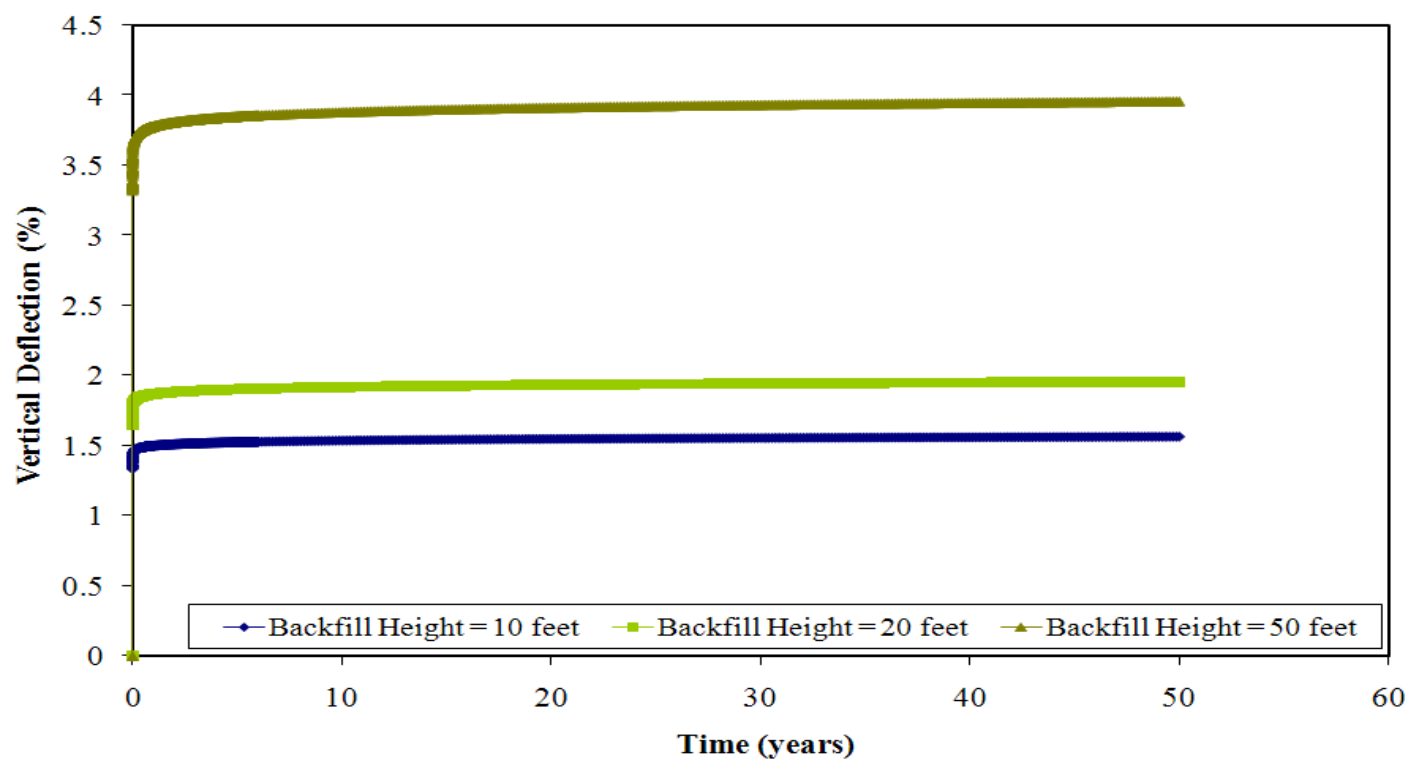

Figure 7.11: Vertical deflections of a 60 inch $(1.50 \mathrm{~m})$ HDPE pipe installed in CLSM under HS-25 load and self-weight of soil.

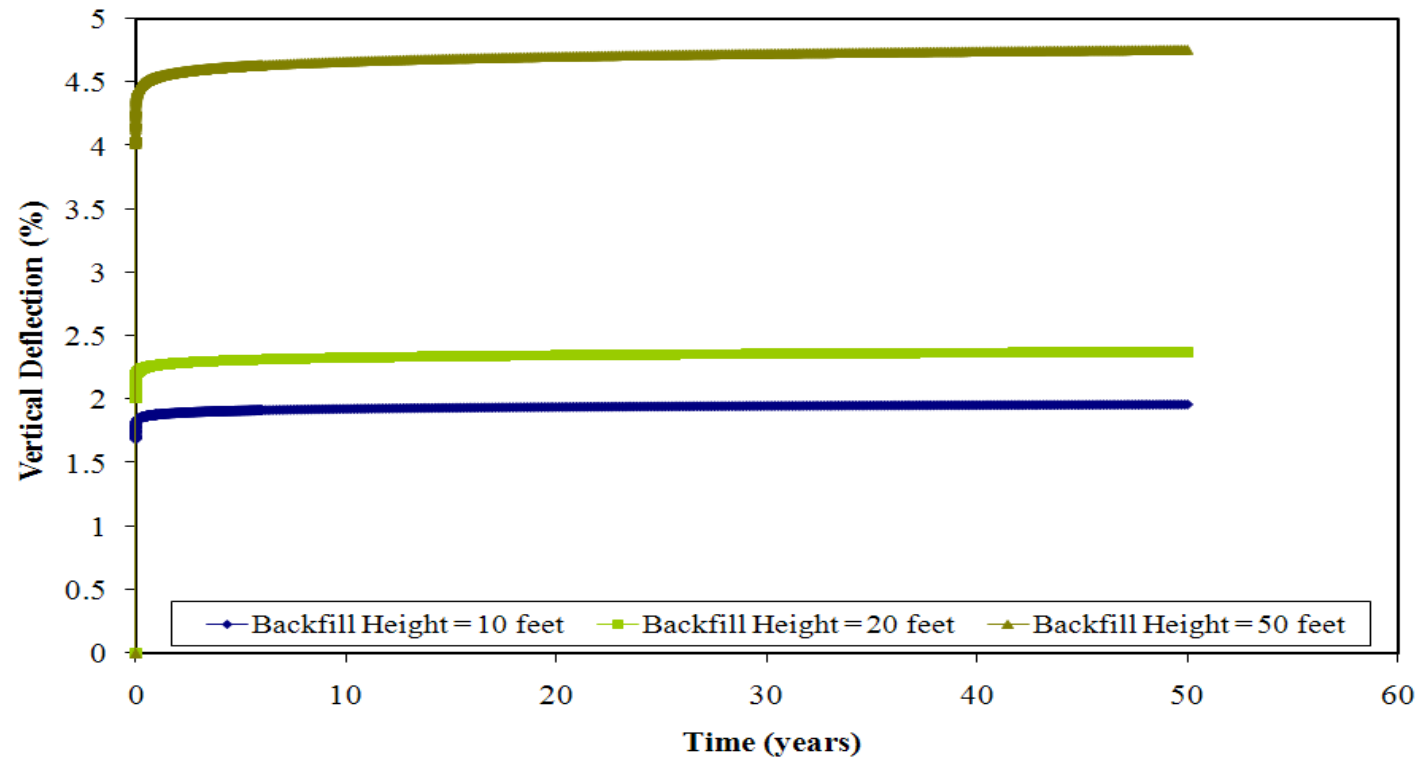

Figure 7.12: Vertical deflections of a 60 inch $(1.50 \mathrm{~m})$ HDPE pipe installed in granular stone under HS-25 load and self-weight of soil. 


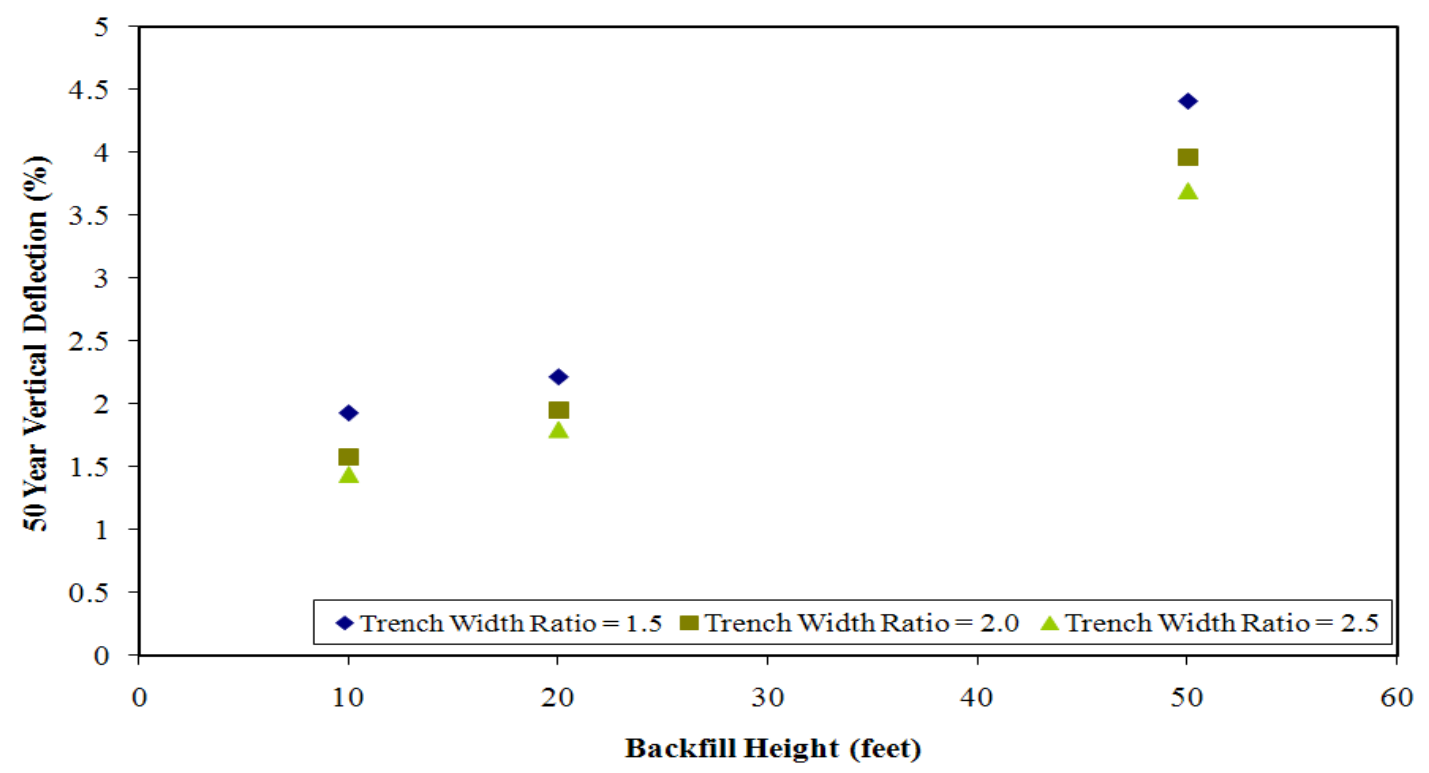

Figure 7.13: Effect of trench width ratio on vertical deflections of a 60 inch $(1.50 \mathrm{~m})$ HDPE pipe installed in CLSM under HS-25 load and self-weight of soil.

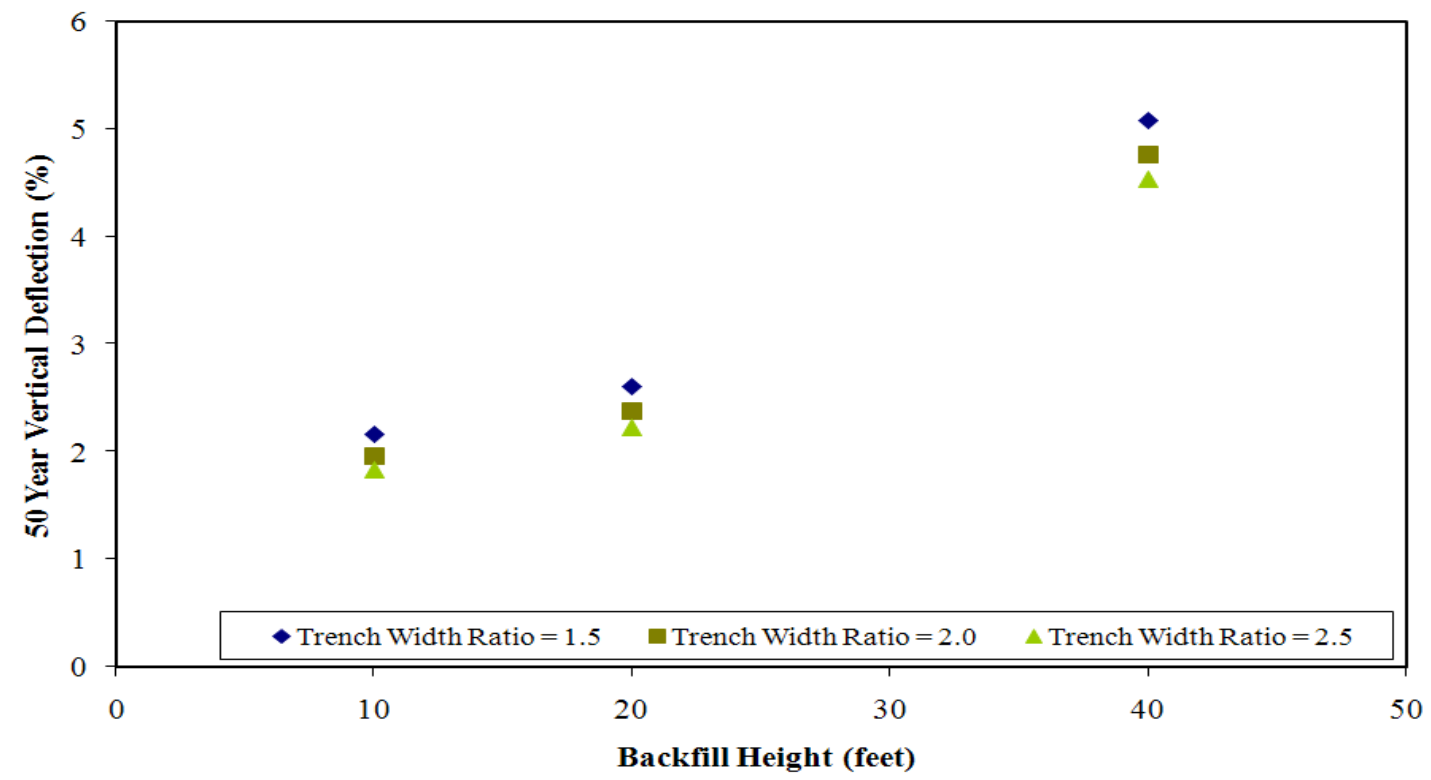

Figure 7.14: Effect of trench width ratio on vertical deflections of a 60 inch $(1.50 \mathrm{~m})$ HDPE pipe installed in granular stone under HS-25 load and self-weight of soil .

The deformation of pipes with various diameters installed under different fill heights and CLSM backfill material are shown in Figure 7.15. The deformation of pipes 
with various diameters installed under different fill heights are and granular stone backfill material are shown in Figure 7.16. The trench width in these cases is equal to two times the mean diameter of the pipe. Results show that that the deflection trend is similar for all pipe diameters. The vertical deformations were higher when granular stone was used as backfill, which is similar to what was presented earlier. Table 7.2 and Table 7.3 present the comparison between the pipe deflections due to self-weight of soil and self-weight of soil plus HS-25 loads under CLSM and granular stone backfill, respectively.

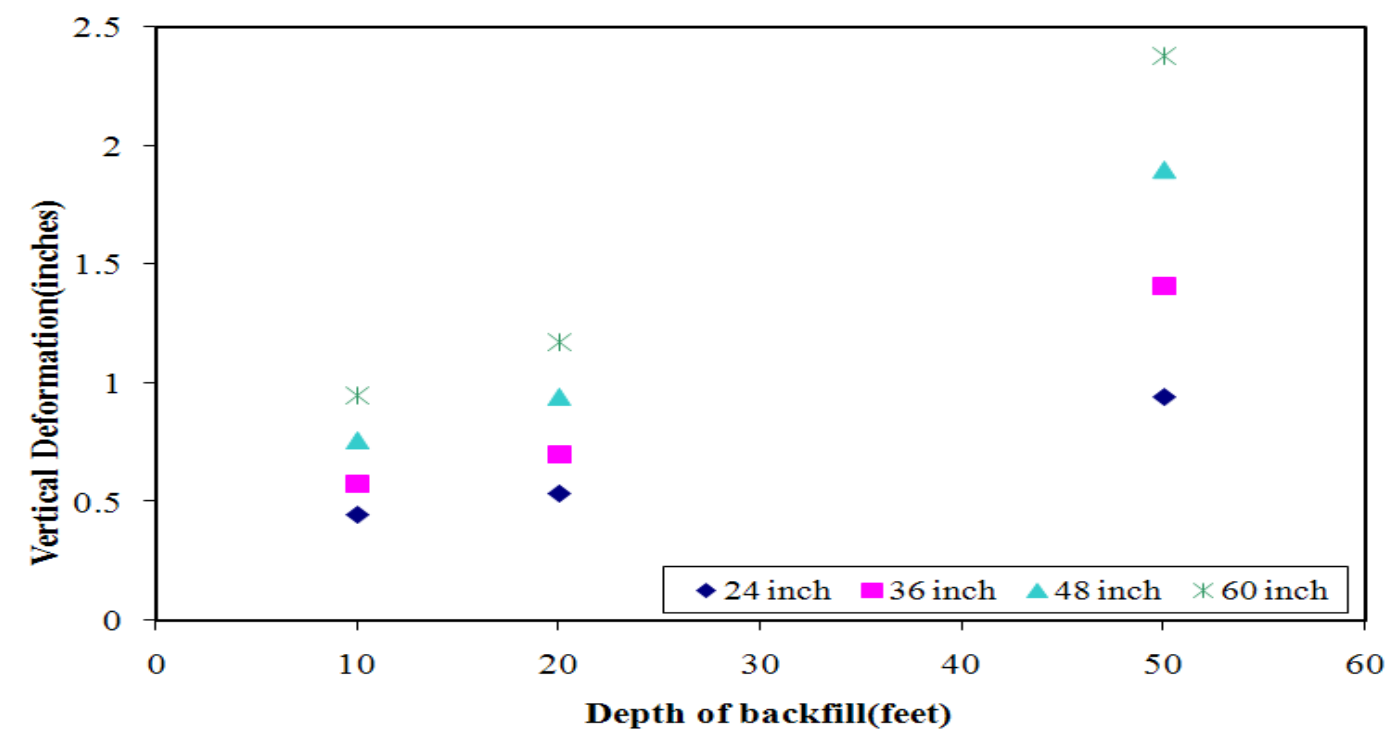

Figure 7.15:Fifty-year vertical deformation of various HDPE pipe diameters installed in CLSM under HS-25 load and self-weight of soil. 


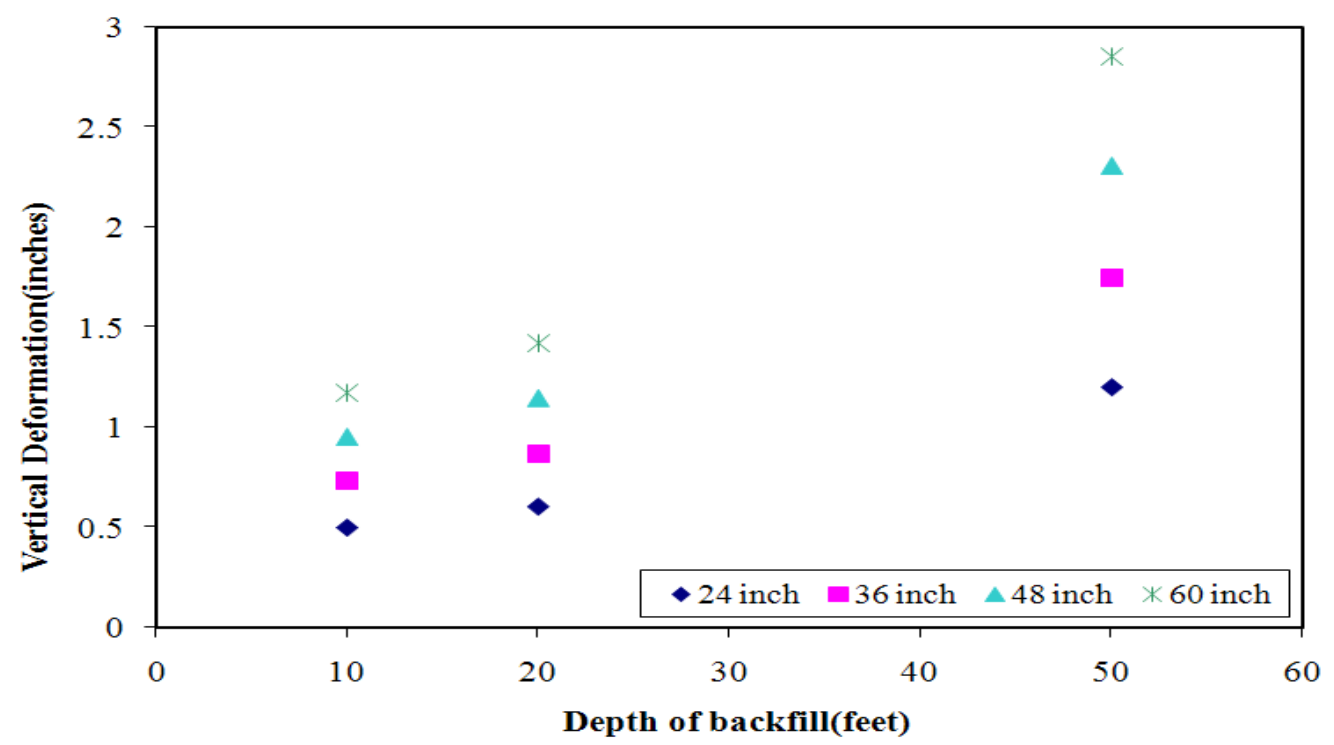

Figure 7.16:Fifty-year vertical deformation of various HDPE pipes diameters installed in granular stone under HS-25 loads and self-weight of soil. 
Table 7.2: Fifty-Year Vertical Deflection of HDPE Pipes Installed in CLSM

\begin{tabular}{|c|c|c|c|c|}
\hline \multirow[b]{2}{*}{$\begin{array}{c}\text { Pipe Diameter } \\
\text { inches (m) }\end{array}$} & \multirow[b]{2}{*}{$\begin{array}{c}\text { Backfill } \\
\text { Depth } \\
\text { (feet) }\end{array}$} & \multicolumn{2}{|c|}{ Vertical Deflection (inches) } & \multirow[b]{2}{*}{$\begin{array}{c}\text { Percentage increases in } \\
\text { deflection }(\%) \\
\left(\frac{\left(V_{\mathbf{d l}}+\mathbf{l l}+V_{\mathbf{d l}}\right)}{V_{\mathbf{d l}}}\right) * 100\end{array}$} \\
\hline & & $\begin{array}{l}\text { Self-weight } \\
\text { of soil }\left(V_{d l}\right)\end{array}$ & $\begin{array}{c}\text { Self-weight } \\
\text { of soil }+ \\
\text { HS-25 load } \\
\left(\mathrm{V}_{\mathrm{d}++\mathrm{II}}\right)\end{array}$ & \\
\hline \multirow{3}{*}{$24(0.60)$} & $10(3)$ & 0.166 & 0.445 & 167 \\
\hline & $20(6)$ & 0.319 & 0.534 & 67 \\
\hline & $50(15)$ & 0.838 & 0.940 & 12 \\
\hline \multirow{3}{*}{$36(0.90)$} & $10(3)$ & 0.231 & 0.574 & 148 \\
\hline & $20(6)$ & 0.468 & 0.698 & 49 \\
\hline & $50(15)$ & 1.251 & 1.407 & 12 \\
\hline \multirow{3}{*}{$48(1.20)$} & $10(3)$ & 0.324 & 0.759 & 134 \\
\hline & $20(6)$ & 0.675 & 0.942 & 40 \\
\hline & $50(15)$ & 1.725 & 1.898 & 10 \\
\hline \multirow{3}{*}{$60(1.50)$} & $10(3)$ & 0.416 & 0.946 & 127 \\
\hline & $20(6)$ & 0.847 & 1.172 & 38 \\
\hline & $50(15)$ & 2.205 & 2.379 & 8 \\
\hline
\end{tabular}


Table 7.3: Fifty Year Vertical Deflection of HDPE pipes Installed in Granular Stone

\begin{tabular}{|c|c|c|c|c|}
\hline \multirow[b]{2}{*}{$\begin{array}{l}\text { Pipe Diameter } \\
\text { inches (m) }\end{array}$} & \multirow[b]{2}{*}{$\begin{array}{c}\text { Backfill } \\
\text { Depth } \\
\text { feet (m) }\end{array}$} & \multicolumn{2}{|c|}{ Vertical Deflection (inches) } & \multirow[b]{2}{*}{$\begin{array}{c}\text { Percentage increases in } \\
\text { deflection (\%) } \\
\left(\frac{\left(V_{\mathbf{d l}+l \mathbf{l}}+\mathbf{V}_{\mathbf{d l}}\right)}{\mathbf{V}_{\mathbf{d l}}}\right) * 100\end{array}$} \\
\hline & & $\begin{array}{l}\text { Self-weight } \\
\text { of soil }\left(V_{d l}\right)\end{array}$ & $\begin{array}{c}\text { Self-weight of } \\
\text { soil + HS-25 } \\
\operatorname{load}\left(V_{\mathrm{dl}+\mathrm{II}}\right)\end{array}$ & \\
\hline \multirow{3}{*}{$24(0.60)$} & $10(3)$ & 0.211 & 0.503 & 138 \\
\hline & $20(6)$ & 0.408 & 0.607 & 49 \\
\hline & 50 (15) & 1.061 & 1.202 & 13 \\
\hline \multirow{3}{*}{$36(0.90)$} & $10(3)$ & 0.292 & 0.732 & 151 \\
\hline & $20(6)$ & 0.614 & 0.869 & 41 \\
\hline & 50 (15) & 1.554 & 1.746 & 12 \\
\hline \multirow{3}{*}{$48(1.20)$} & $10(3)$ & 0.407 & 0.953 & 134 \\
\hline & $20(6)$ & 0.824 & 1.147 & 39 \\
\hline & 50 (15) & 2.102 & 2.308 & 10 \\
\hline \multirow{3}{*}{$60(1.50)$} & $10(3)$ & 0.521 & 1.175 & 126 \\
\hline & $20(6)$ & 1.029 & 1.424 & 38 \\
\hline & $50(15)$ & 2.653 & 2.855 & 8 \\
\hline
\end{tabular}

From Tables 7.2 and 7.3, the variation in deflection percentages indicates that the effect of live loads decreases with an increase in backfill depth. At depths greater than 20 feet $(6 \mathrm{~m})$, the changes in vertical deflection are not so significant.

\subsection{Numerical results for polyvinyl chloride (PVC) pipes}

Creep analyses were performed on a solid-wall polyvinyl chloride pipes (PVC) of diameter 18 inch $(0.45 \mathrm{~m}), 21$ inch $(0.52 \mathrm{~m})$, and 24 inches $(0.60 \mathrm{~m})$. Fill heights of 10 feet $(3 \mathrm{~m}), 20$ feet $(6 \mathrm{~m})$, and 50 feet $(15 \mathrm{~m})$ were considered. In this section, results 
obtained for a 24 inch $(0.60 \mathrm{~m})$ pipe are presented since it appears to be the worst-case scenario. A comparison of the performance of other pipe sizes is then presented.

\subsubsection{Response due to self-weight of the soil}

The response of a 24 inch PVC pipe under self-weight of soil, different pipe backfill materials, and different trench widths are presented in this section. Figure 7.17 shows the fifty-year deformation contours of the pipe-soil system under self-weight of soil. Figure 7.18 shows the fifty-year vertical pipe deflections (expressed as a \%) of a 24 inch $(0.60 \mathrm{~m})$ solid-wall PVC pipe installed in CLSM and granular stone pipe backfill. The pipe is installed at a depth of 50 feet $(15 \mathrm{~m})$ in a trench width equal to two times the mean diameter of the pipe. The pipe deflections were computed by taking the difference between the magnitudes of vertical displacement at the crown and base of the pipe.

Figure 7.18 shows a comparison of pipe deflections under different pipe backfill material. A gradual increase in the pipe deflection over time can be seen. Figure 7.18 also shows that beyond one year of installation the creep deformation was just $20 \%$ $40 \%$ of the total deflection. Vertical pipe deflections were higher when granular stone was used as pipe backfill. With an increase in backfill heights, the vertical pipe deflections increased as shown in Figure 7.19 and Figure 7.20. Figure 7.21 and Figure 7.22 show the influence of trench width on the pipes installed in CLSM and granular stone pipe backfill, respectively. Pipe deflection decreased with an increase in trench

width. Also, Figures 7.21 and 7.22 illustrate that a 24 inch $(0.60 \mathrm{~m})$ solid-wall PVC pipe can be installed up to 50 feet $(15 \mathrm{~m})$ with the trench width ratio as small as 1.5 without causing a pipe failure. 

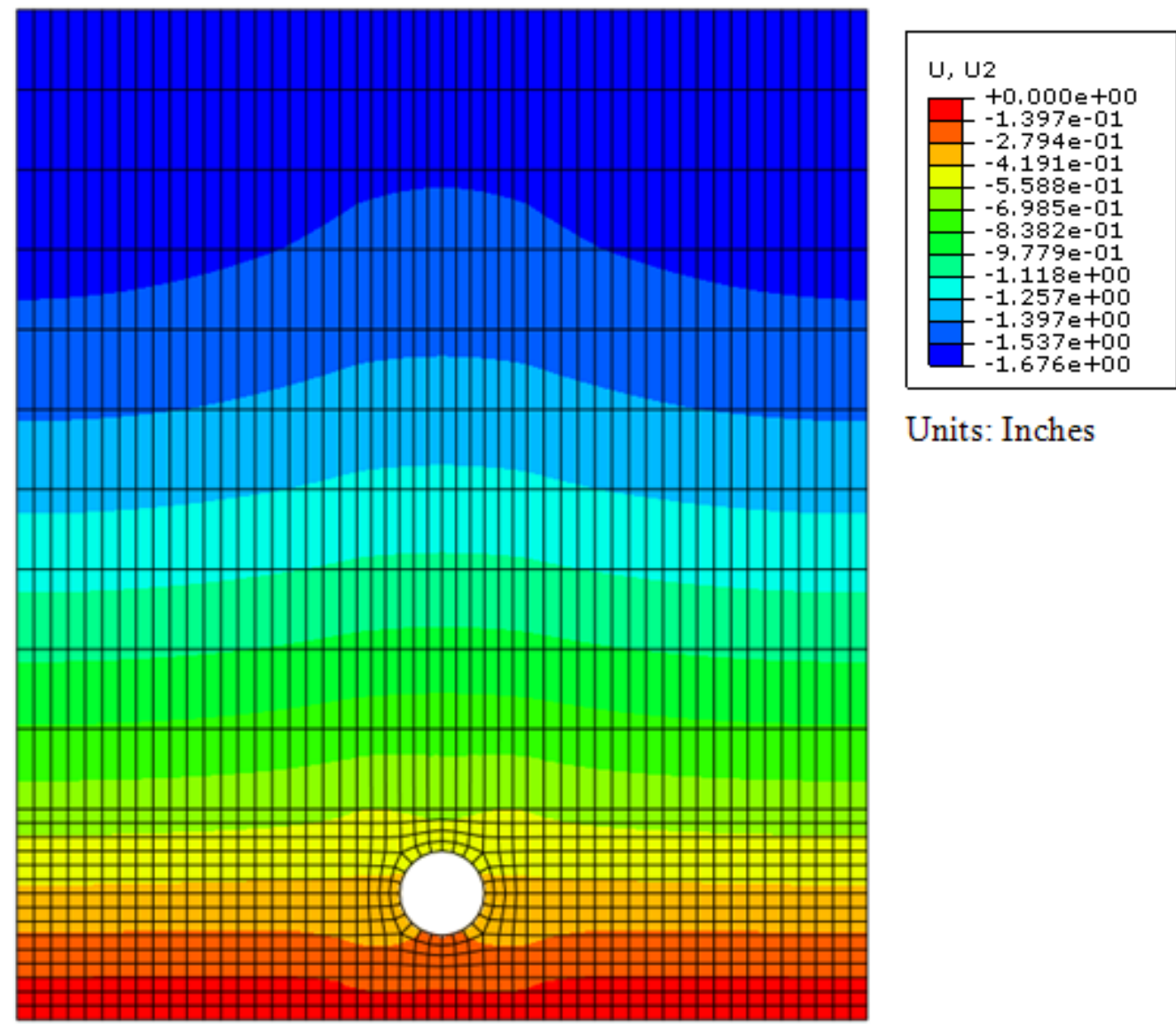

Units: Inches

Figure 7.17: Fifty-year deformation in the soil-pipe system due to self-weight of the soil. 


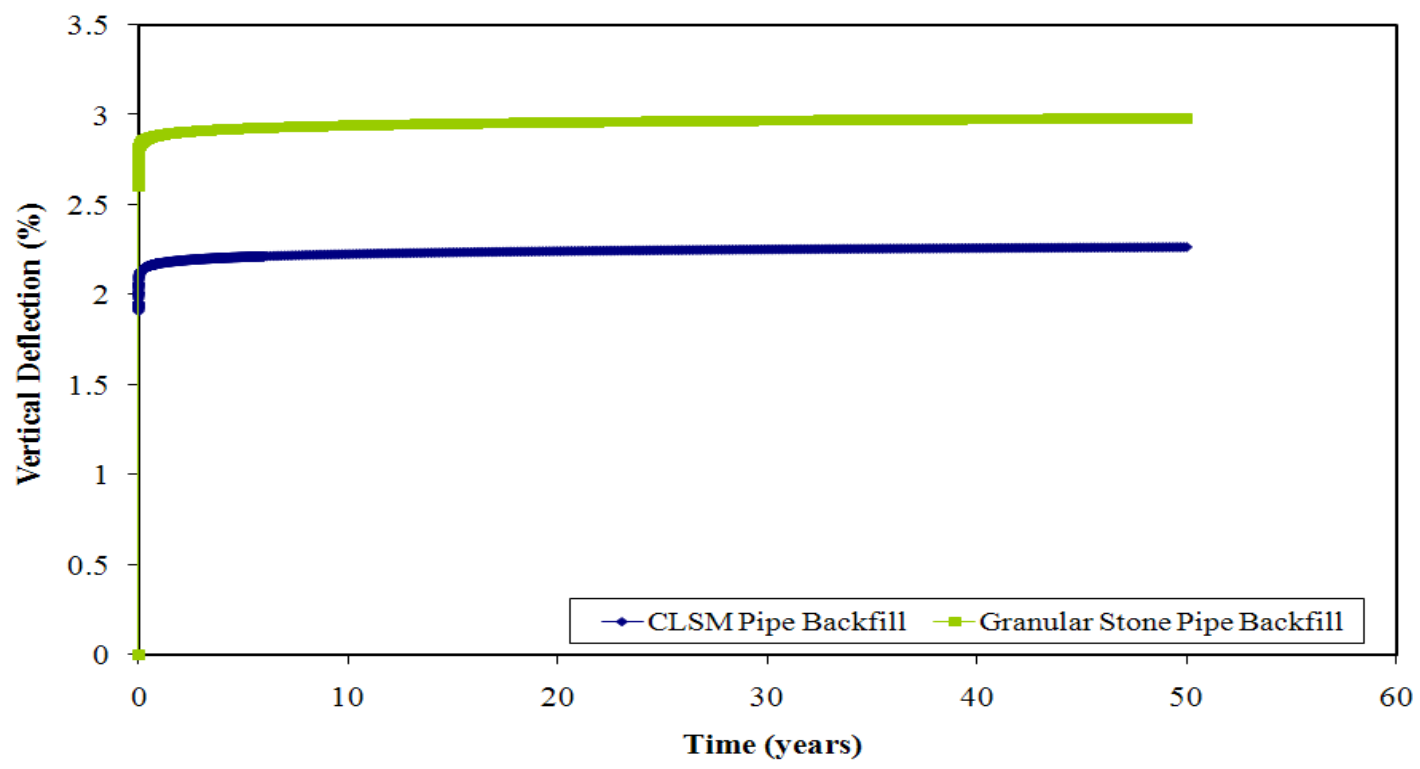

Figure 7.18: Fifty-year vertical deflection of a 24 inch $(0.60 \mathrm{~m})$ PVC pipe installed at a depth of 50 feet $(6 \mathrm{~m})$. 


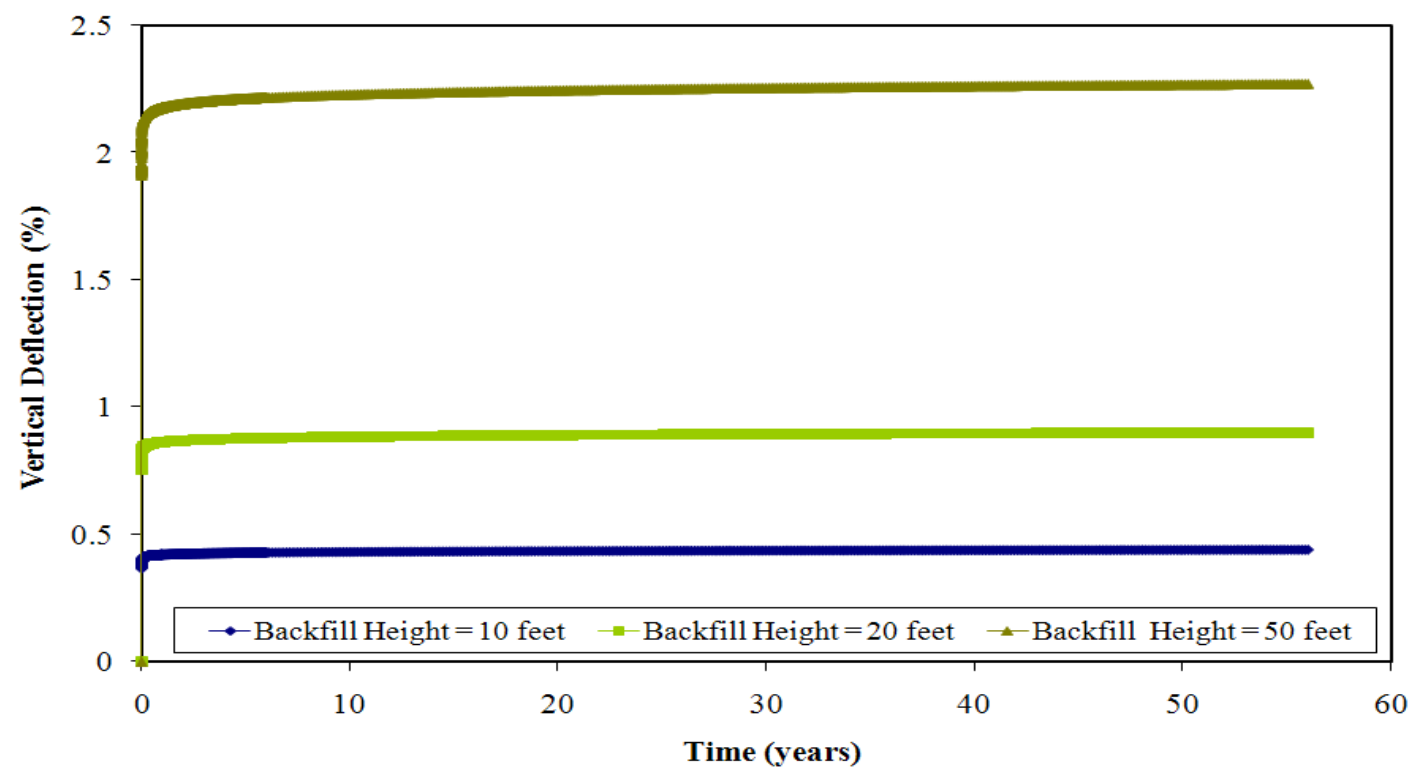

Figure 7.19: Vertical pipe deflection of a 24 inch $(0.60 \mathrm{~m})$ PVC pipe installed in CLSM under increasing backfill heights.

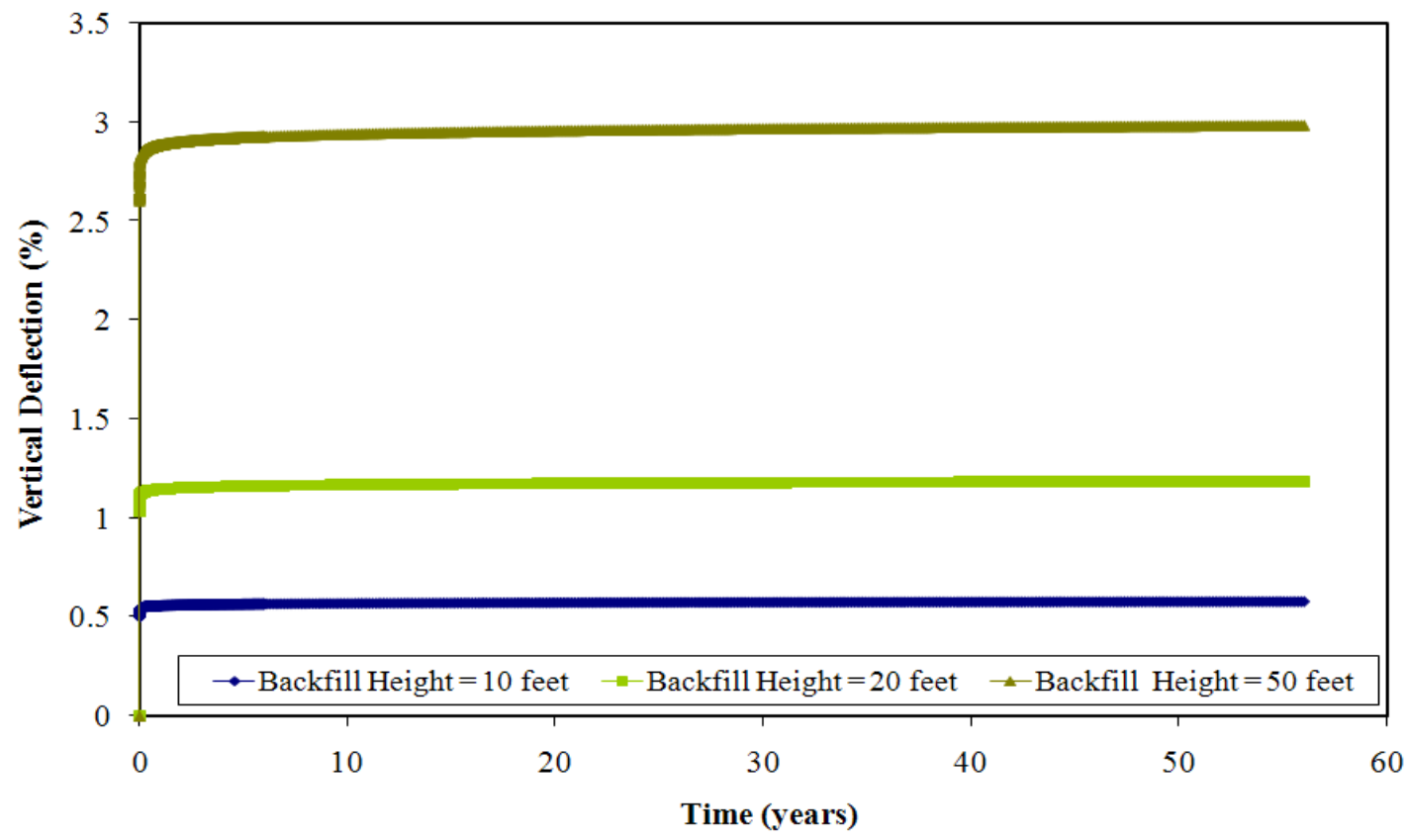

Figure 7.20: Vertical deflection of a 24 inch $(0.60 \mathrm{~m})$ PVC pipe installed in granular stone under increasing backfill heights. 


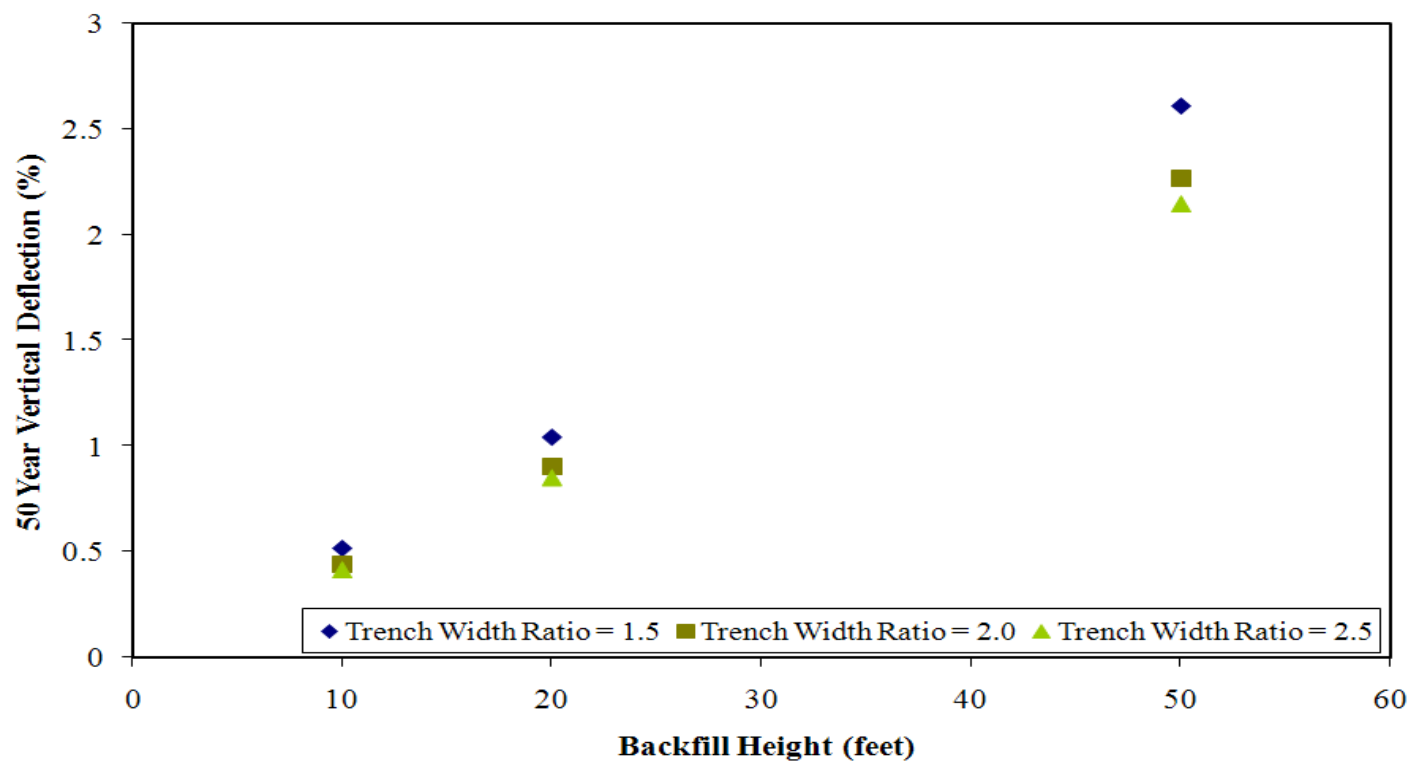

Figure 7.21: Effect of trench width on the vertical pipe deflection of a 24 inch $(0.60 \mathrm{~m})$ PVC pipe installed in CLSM.

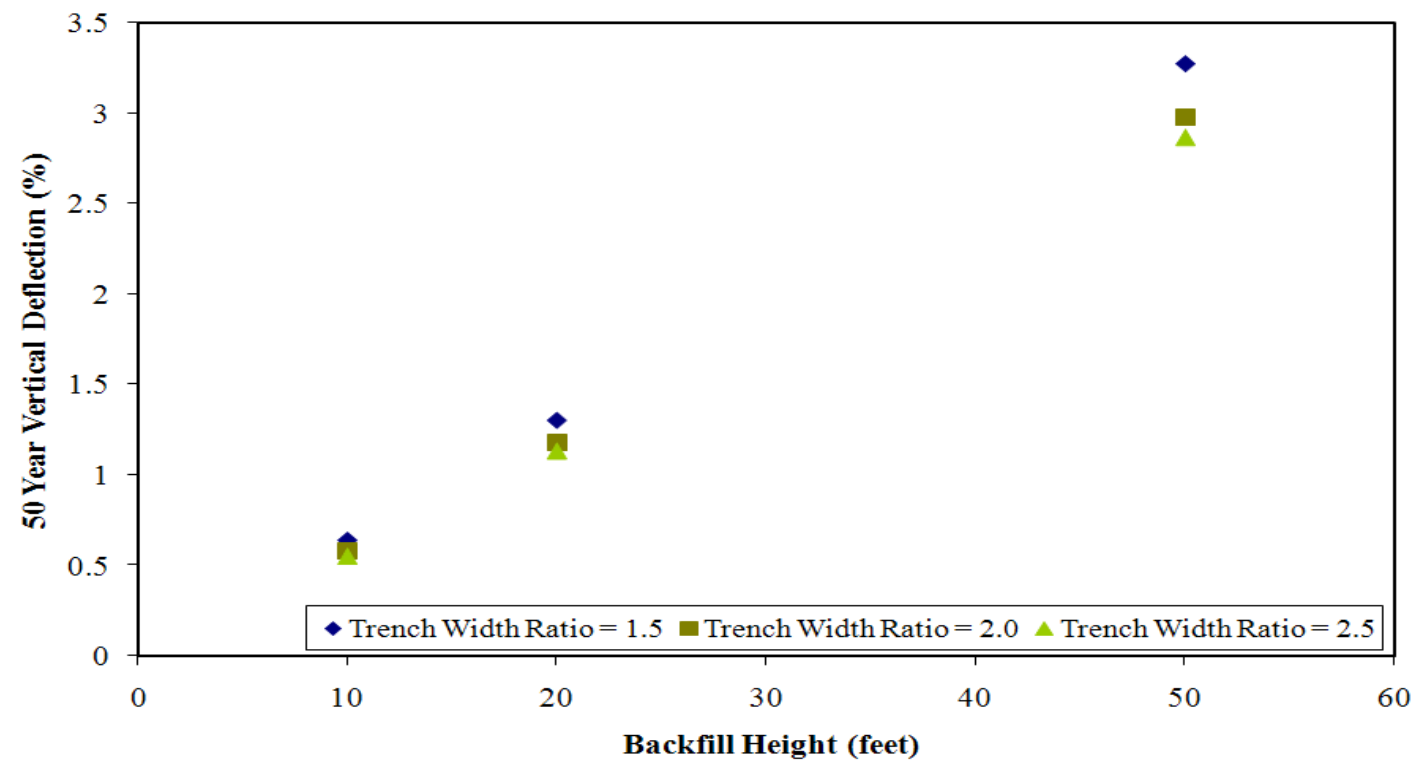

Figure 7.22: Effect of trench width on the vertical pipe deflection of a 24 inch $(0.60 \mathrm{~m})$ PVC pipe installed in granular stone. 
The deformation of pipes with various diameters installed under different fill heights and CLSM are shown in Figure 7.23. The deformation of pipes with various diameters installed under different fill heights and granular stone are shown in Figure 7.24. The trench width is equal to two times the mean diameter of the pipe. Results show that that the deflection trend is similar for all the pipe diameters. The vertical deformations were higher when granular stone was used as pipe backfill, which is similar to what was presented earlier. 


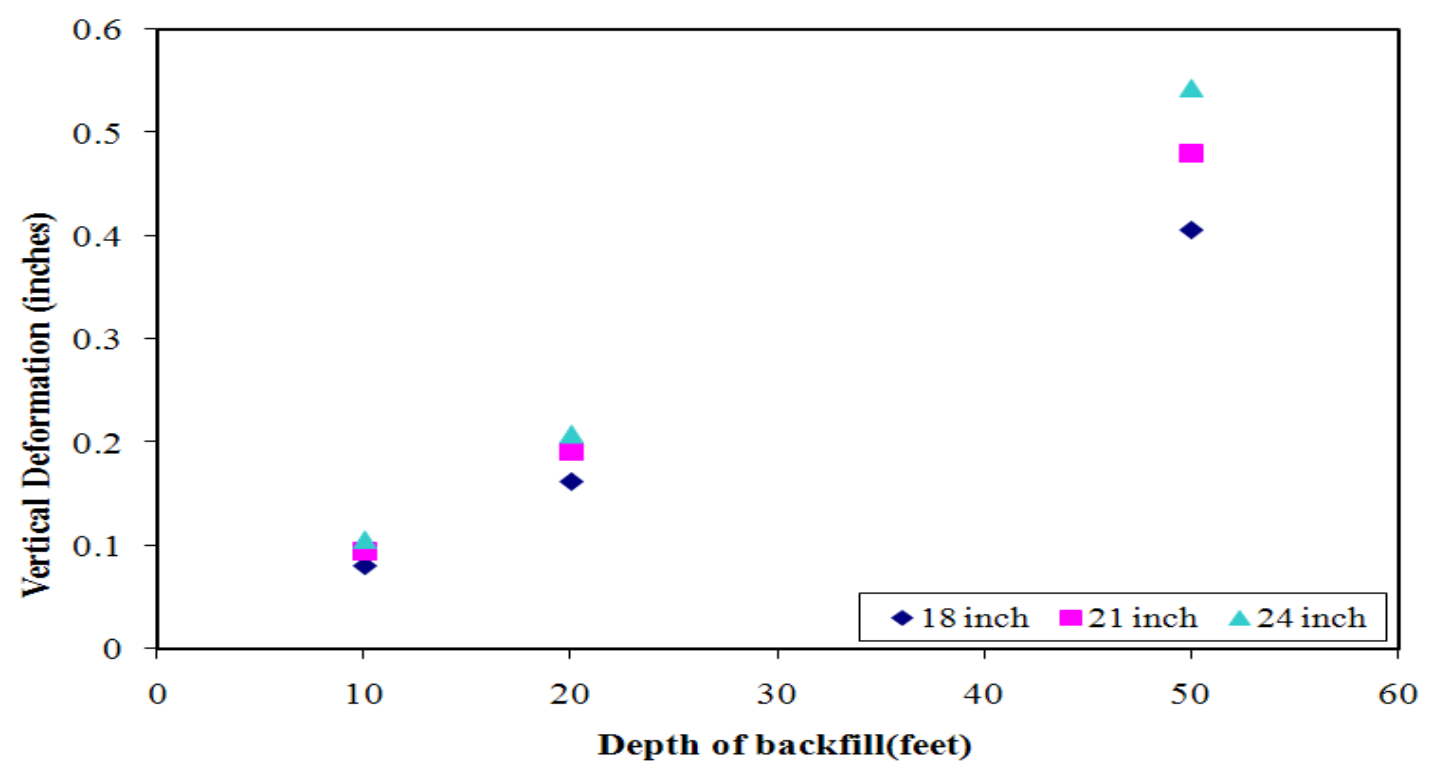

Figure 7.23: Fifty-year vertical deformation of various PVC pipe diameters installed in CLSM.

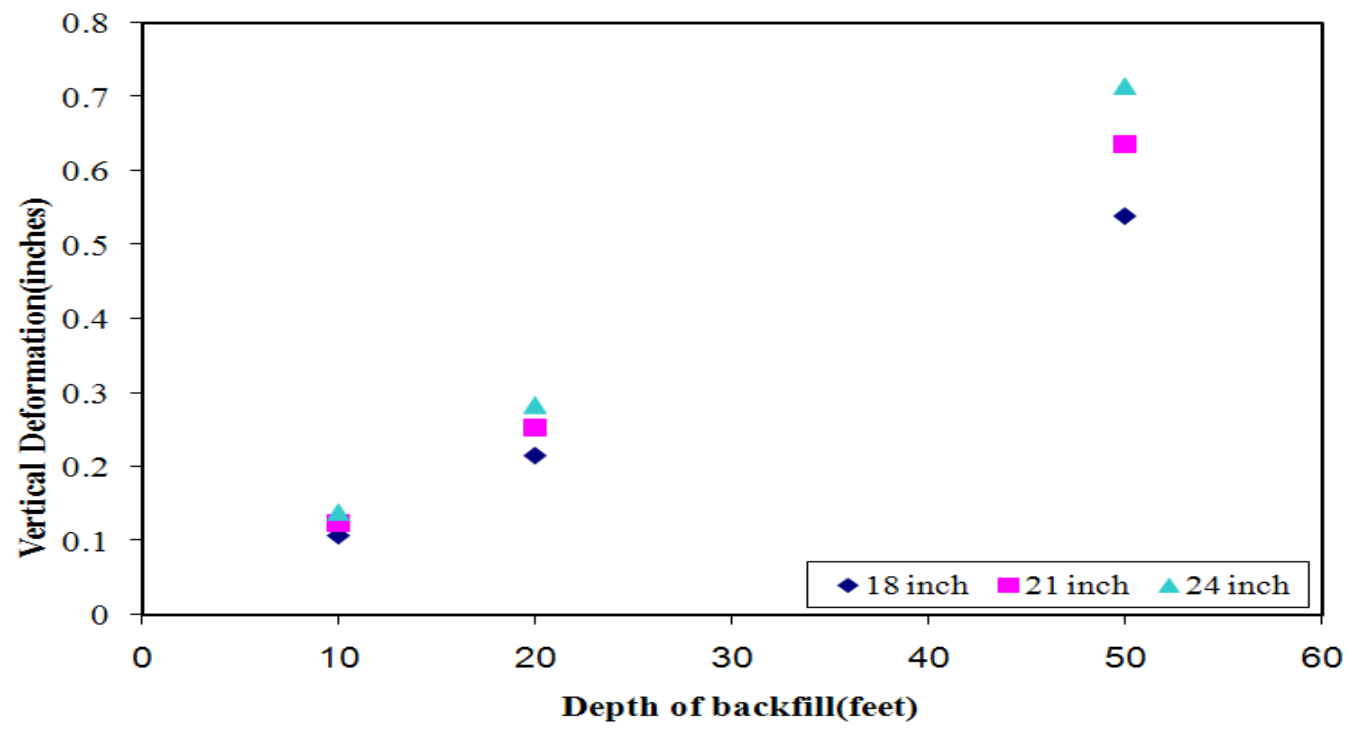

Figure 7.24:Fifty-year vertical deformation of various PVC pipe diameters installed in granularstone. 


\subsubsection{Response due to HS $\mathbf{- 2 5}$ truck loading + self-weight of the soil}

Figure 7.25 shows the fifty year deformation contours of the pipe-soil system under HS-25 load and self-weight of soil. The depth of backfill is 20 feet $(6 \mathrm{~m})$ with CLSM as the pipe backfill. Figure 7.26 shows the fifty-year vertical pipe deflections (expressed as a \%) of a 24 inch $(0.60 \mathrm{~m})$ solid-wall PVC pipe. The pipe is installed in CLSM and granular stone pipe backfill at a depth of 50 feet $(15 \mathrm{~m})$ in a trench width equal to two times the mean diameter of the pipe. The pipe deflections were computed by taking the difference between the magnitudes of vertical displacement at the crown and base of the pipe.

Figure 7.26 show a comparison of pipe deflections under different pipe backfill materials. A gradual increase in the pipe deflection over time can be seen. Figure 7.26 also shows that beyond one year of installation the creep deformation was just $20 \%$ $40 \%$ of the total deflection. Figure 7.27 and Figure 7.28 show the percentage vertical deflection of a 24 inch $(0.60 \mathrm{~m})$ PVC pipe, under increasing fill heights, installed in CLSM and granular stone, respectively. The vertical pipe deflection increased with an increase in backfill height. Figures 7.29 and 7.30 show the influence of trench width on the pipe installed in CLSM and granular stone, respectively. With an increase in trench width the vertical pipe deflections decreased. Also, Figures 7.29 and 7.30 illustrate that a 24 inch $(0.60 \mathrm{~m})$ solid- wall PVC pipe can be installed up to a depth of 50 feet $(15 \mathrm{~m})$ with the trench width ratio as small as 1.5 without causing a pipe failure. 

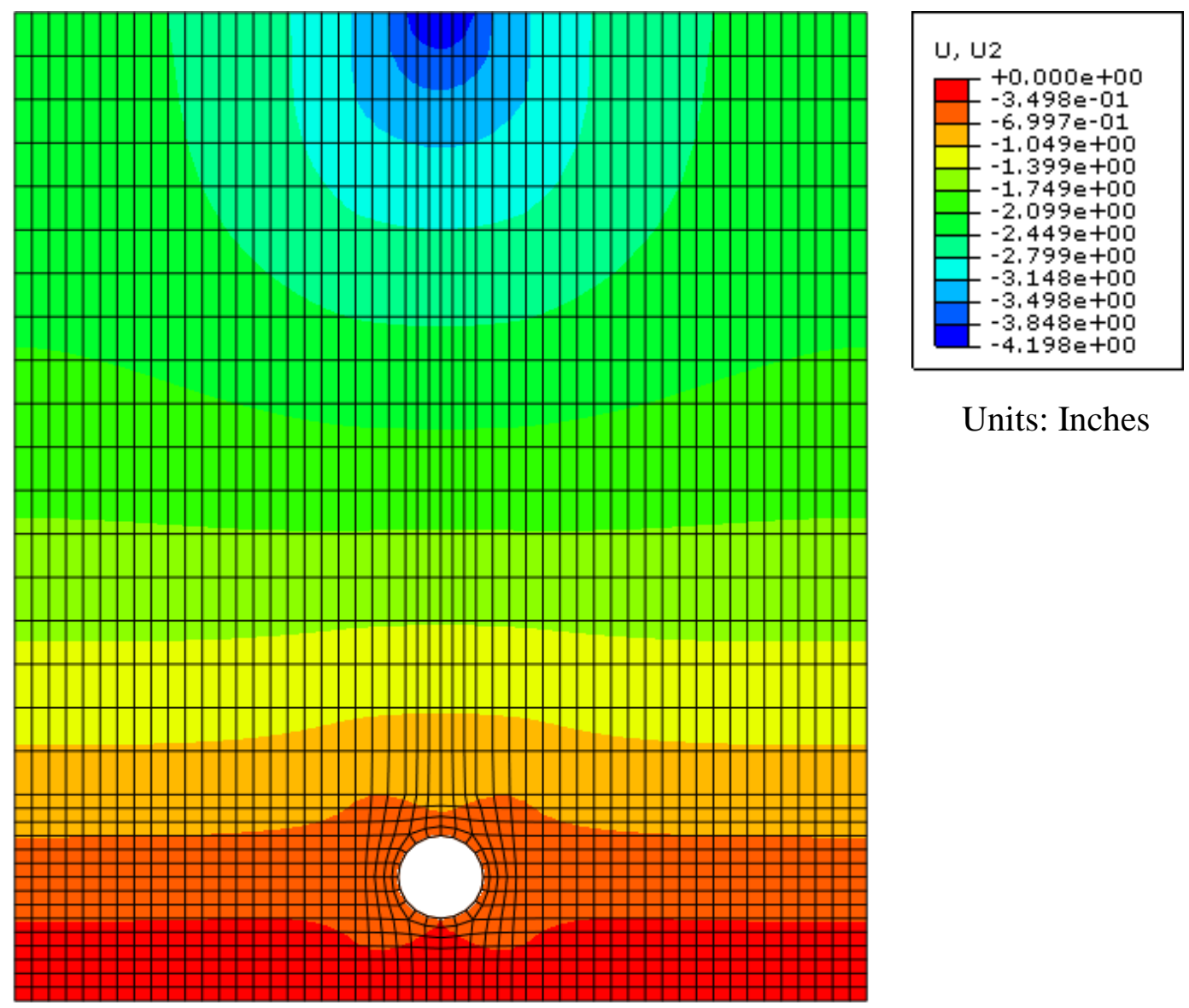

Units: Inches

Figure 7.25: Fifty-year deformation in the soil-pipe system under HS-25 truck loading. 


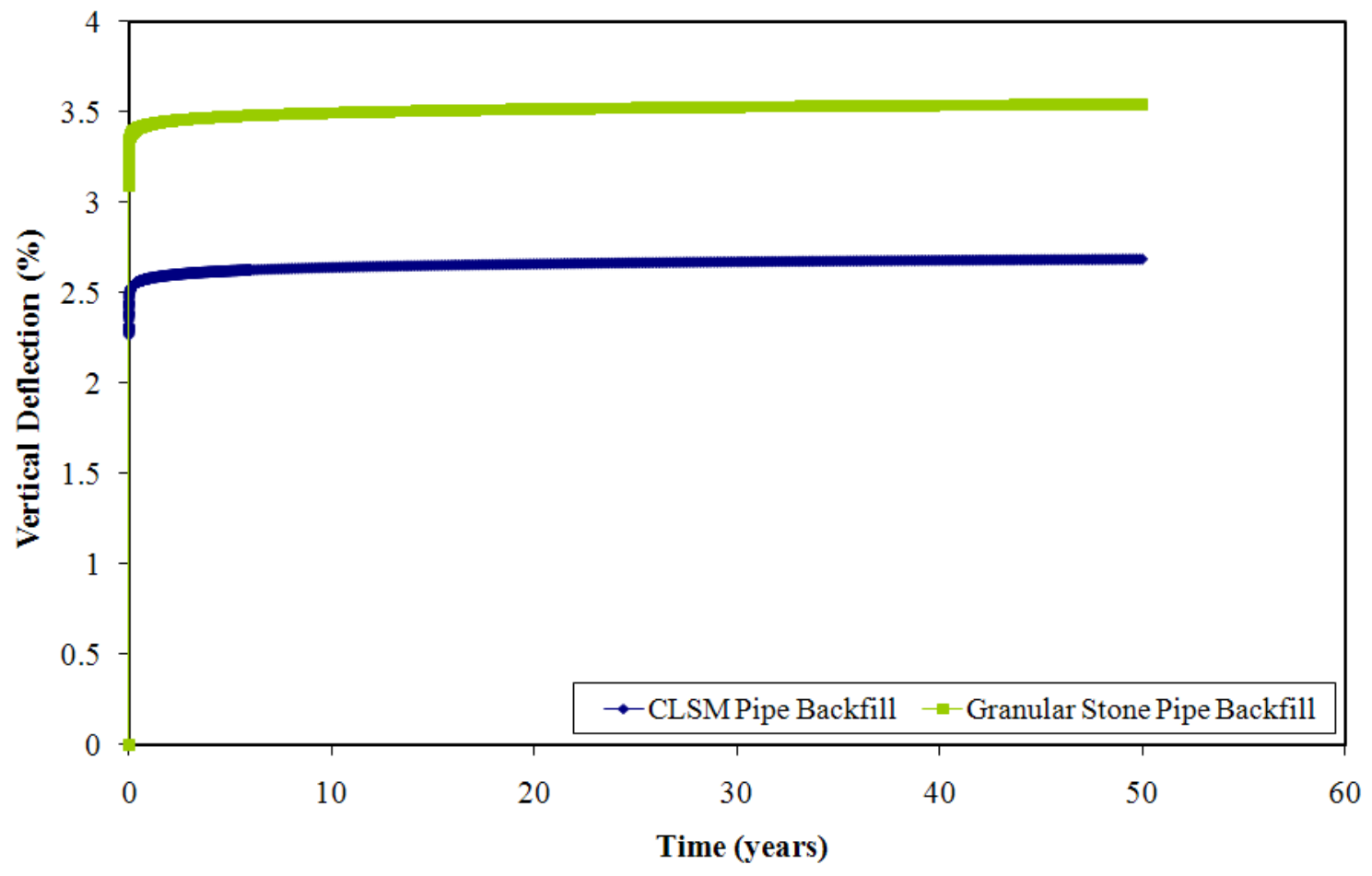

Figure 7.26: Fifty-year vertical deflection of a 24 inch $(0.60 \mathrm{~m})$ PVC pipe under HS-25 loading and self-weight of soil. 


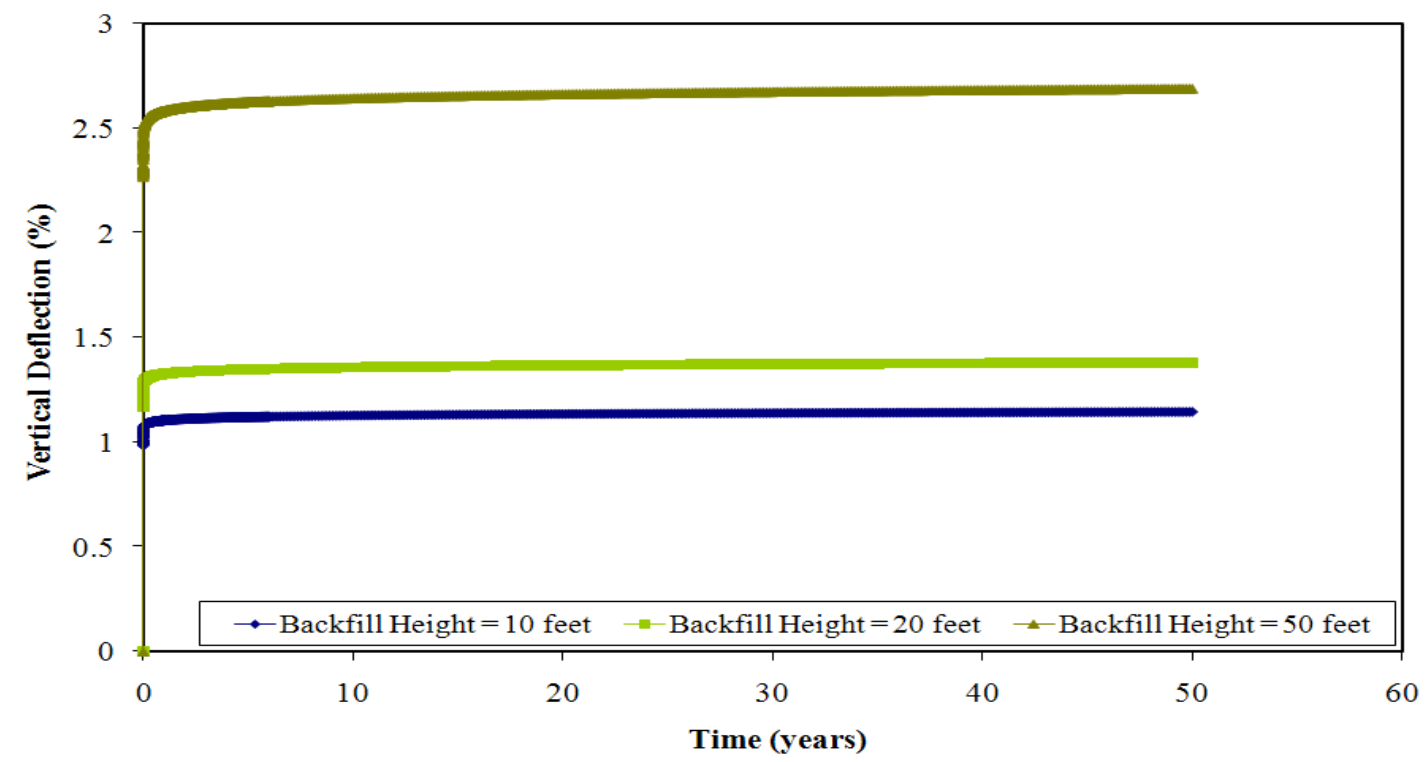

Figure 7.27: Vertical deflections of a 24 i nch $(0.60 \mathrm{~m})$ PVC pipe installed in CLSM under HS-25 load and self-weight of soil.

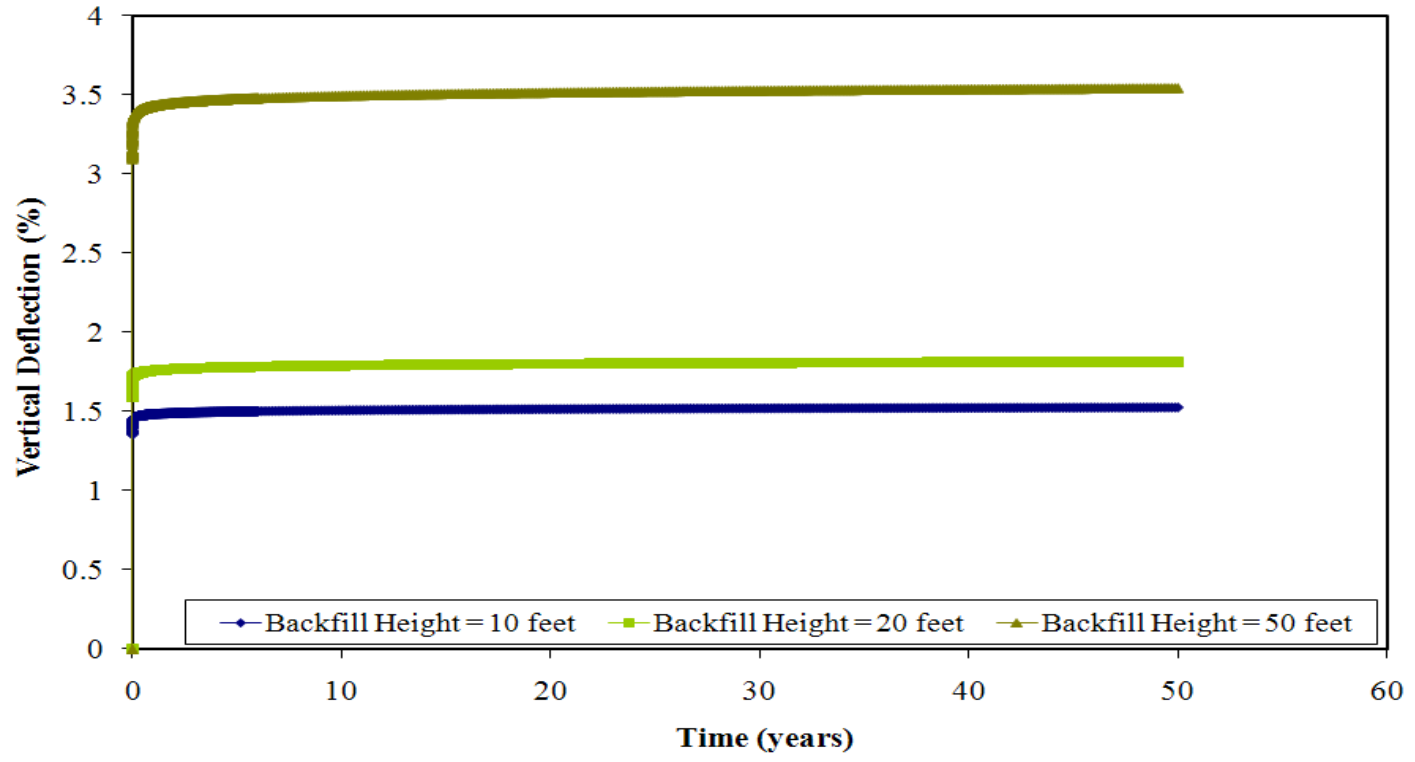

Figure 7.28: Vertical deflections of a 24 inch $(0.60 \mathrm{~m})$ PVC pipe installed in granular stone under HS-25 load and self-weight of soil. 


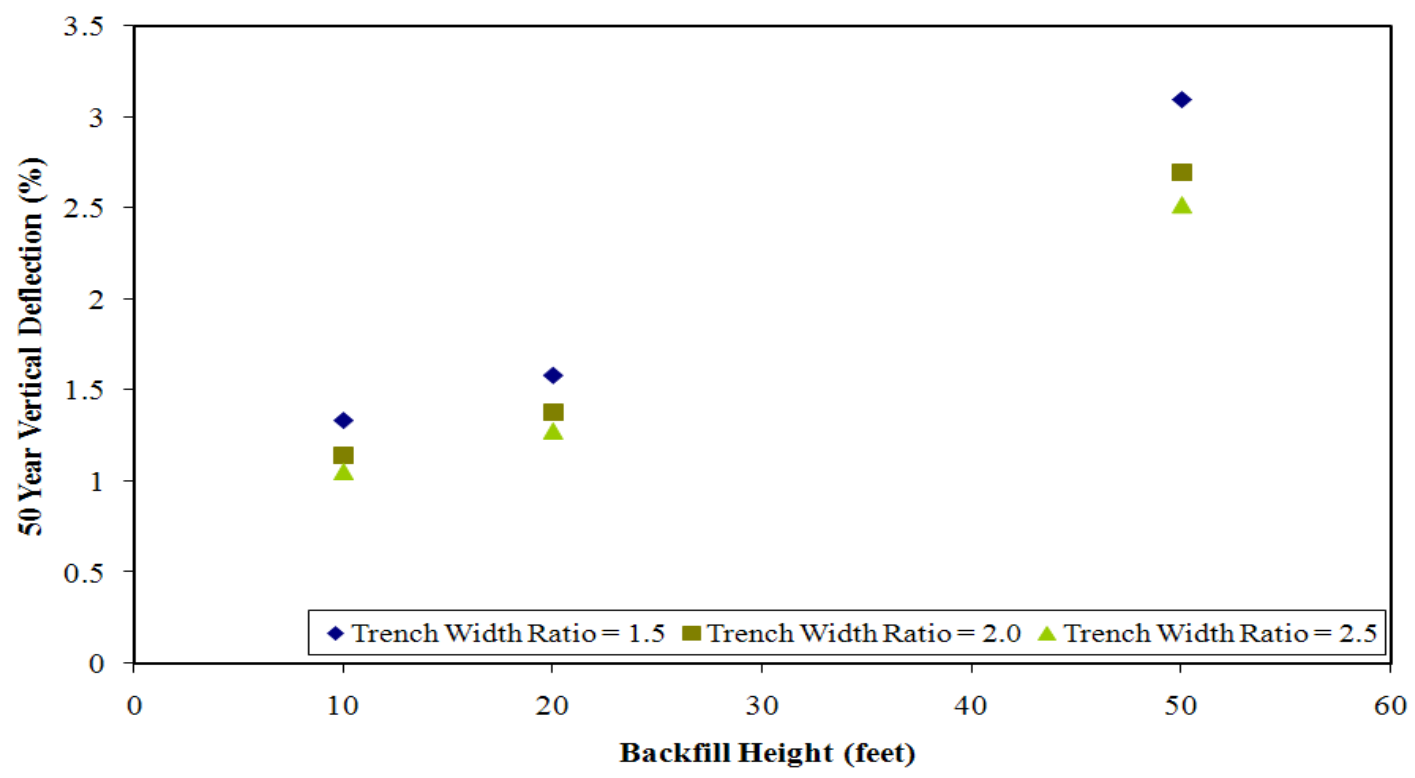

Figure 7.29: Effect of trench width ratio on the vertical deflection of a 24 inch $(0.60 \mathrm{~m})$ PVC pipe installed in CLSM under HS-25 load and self-weight of soil.

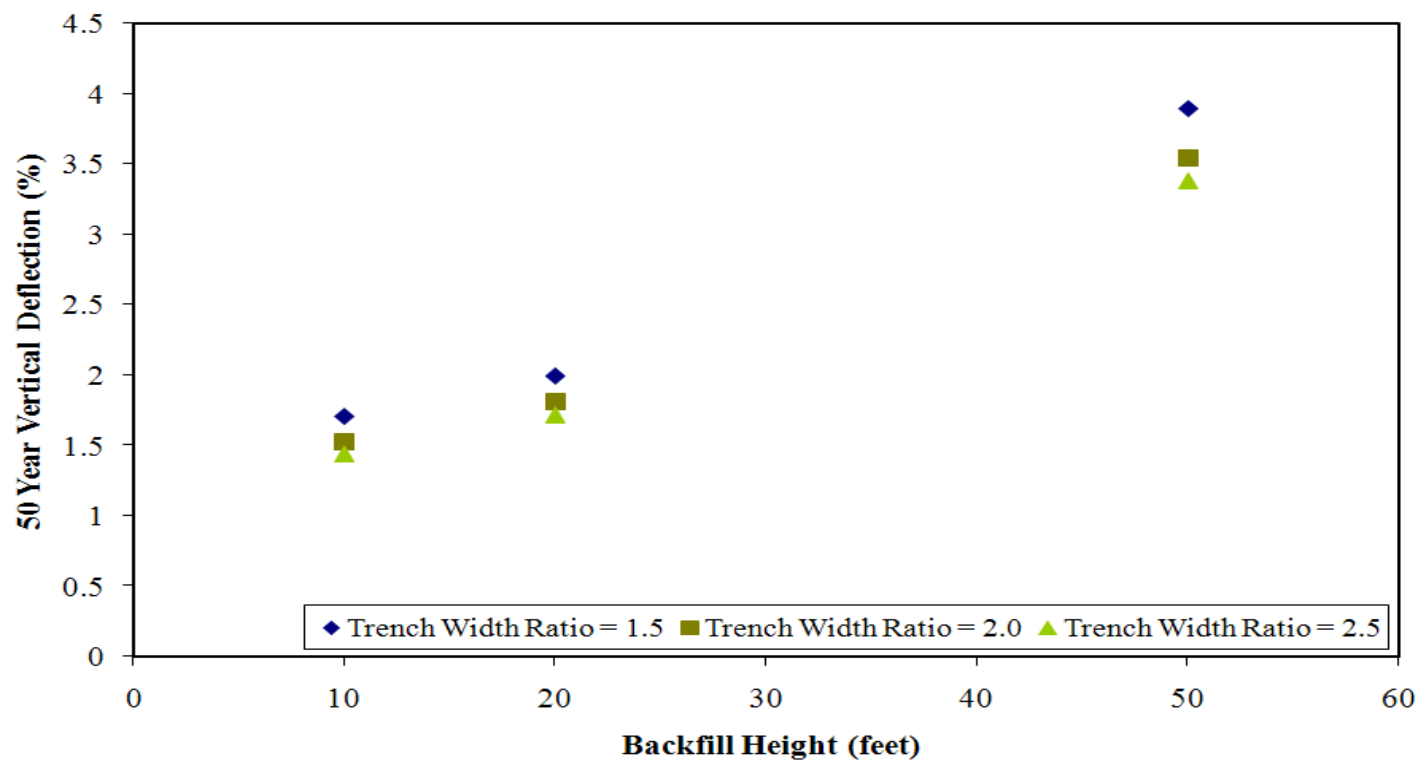

Figure 7.30: Effect of trench width ratio on the vertical deflection of a 24 inch $(0.60 \mathrm{~m})$ PVC pipe installed in granular stone under HS-25 load and self-weight of soil.

The deformation of pipes with various diameters installed under different fill heights and CLSM are shown Figure 7.31. The deformation of pipes with various 
diameters installed under different fill heights and granular stone are shown in Figure 7.32. The trench width is equal to two times the mean diameter of the pipe. Results show that the deflection trend is similar for all pipe diameters. The vertical deflections were higher when granular stone is used as backfill, which is similar to what was presented earlier. Tables 7.4 and 7.5 present the comparison between the pipe deflections due to self-weight of soil and self-weight of soil plus HS-25 loads under CLSM and granular stone backfill, respectively.

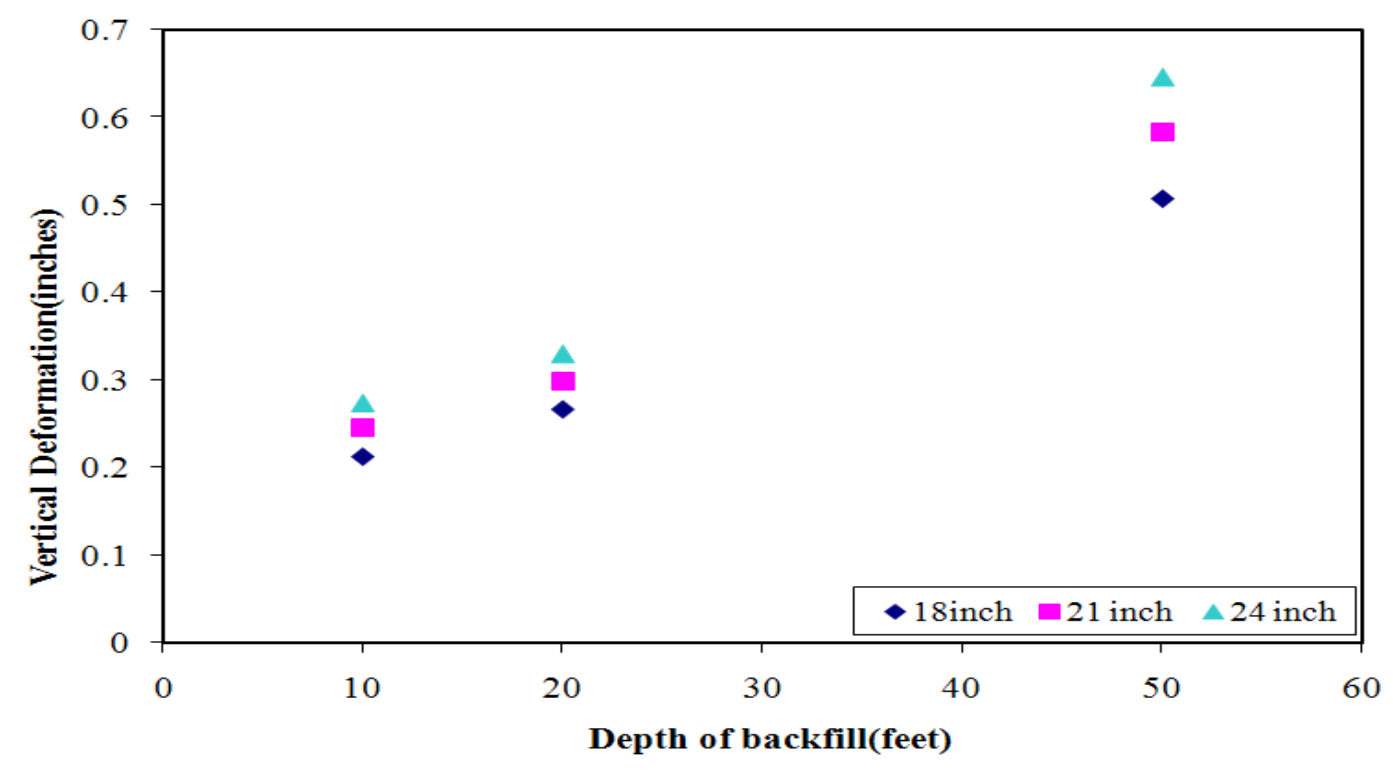

Figure 7.31:Fifty- year vertical deformation of various PVC pipe diameters installed in CLSM pipe backfill under HS-25 loads and self-weight of soil. 


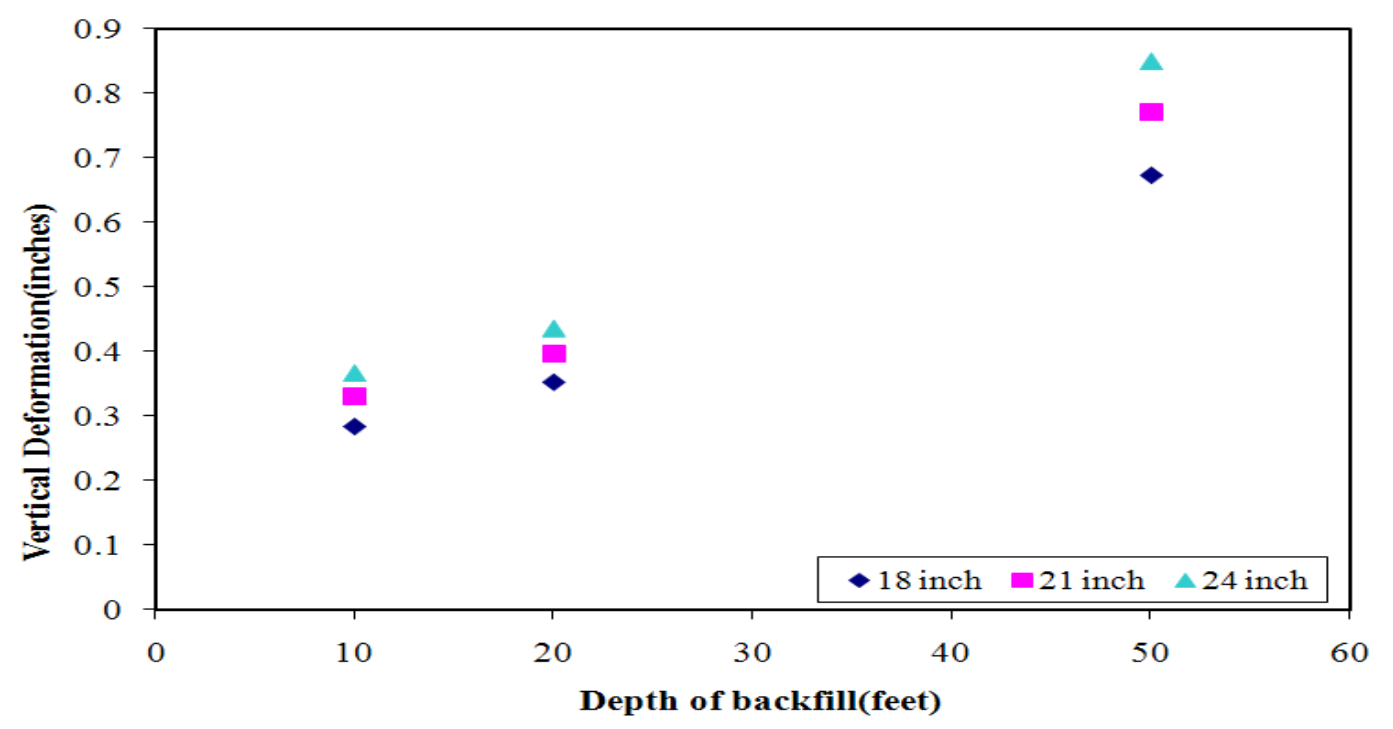

Figure 7.32: Fifty-year deformation of various PVC pipe diameters installed in granular stone under HS-25 loads and self-weight of soil. 
Table 7.4: Fifty-Year Vertical Deflection of PVC Pipes Installed in CLSM

\begin{tabular}{|c|c|c|c|c|}
\hline \multirow[b]{2}{*}{$\begin{array}{l}\text { Pipe Diameter } \\
\text { inches (m) }\end{array}$} & \multirow[b]{2}{*}{$\begin{array}{c}\text { Backfill } \\
\text { Depth } \\
\text { feet }(m)\end{array}$} & \multicolumn{2}{|c|}{ Vertical Deflection (inches) } & \multirow[b]{2}{*}{$\begin{array}{c}\text { Percentage increases in } \\
\text { deflection }(\%) \\
\left(\frac{\left(\mathrm{V}_{\mathrm{dl}+\mathrm{Il}-} \mathrm{V}_{\mathrm{dl}}\right)}{\mathrm{V}_{\mathrm{dl}}}\right) * 100\end{array}$} \\
\hline & & $\begin{array}{l}\text { Self-weight } \\
\text { of soil }\left(V_{d l}\right)\end{array}$ & $\begin{array}{c}\text { Self-weight } \\
\text { of soil + } \\
\text { HS-25 load } \\
\left(V_{d 1+l l}\right)\end{array}$ & \\
\hline \multirow{3}{*}{$18(0.45)$} & $10(3)$ & 0.08061 & 0.2128 & 164 \\
\hline & $20(6)$ & 0.1623 & 0.26693 & 64 \\
\hline & 50 (15) & 0.4063 & 0.508 & 25 \\
\hline \multirow{3}{*}{$21(0.52)$} & $10(3)$ & 0.094 & 0.2458 & 161 \\
\hline & $20(6)$ & 0.1911 & 0.2995 & 57 \\
\hline & $50(15)$ & 0.4807 & 0.5835 & 21 \\
\hline \multirow{3}{*}{$24(0.60)$} & $10(3)$ & 0.1057 & 0.27462 & 160 \\
\hline & $20(6)$ & 0.2081 & 0.33056 & 59 \\
\hline & $50(15)$ & 0.54362 & 0.6457 & 19 \\
\hline
\end{tabular}


Table 7.5: Fifty-Year Vertical Deflection of PVC Pipes Installed in Granular Stone

\begin{tabular}{|c|c|c|c|c|}
\hline \multirow[b]{2}{*}{$\begin{array}{l}\text { Pipe Diameter } \\
\text { inches (m) }\end{array}$} & \multirow[b]{2}{*}{$\begin{array}{l}\text { Backfill } \\
\text { Depth } \\
\text { feet }(\mathrm{m})\end{array}$} & \multicolumn{2}{|c|}{ Vertical Deflection (inches) } & \multirow[b]{2}{*}{$\begin{array}{c}\text { Percentage increases in } \\
\text { deflection }(\%) \\
\left(\frac{\left(\mathrm{V}_{\mathrm{dl}+\mathrm{ll}-} \mathrm{V}_{\mathrm{dl}}\right)}{\mathrm{V}_{\mathrm{dl}}}\right) * 100\end{array}$} \\
\hline & & $\begin{array}{l}\text { Self-weight } \\
\text { of soil }\left(V_{d l}\right)\end{array}$ & $\begin{array}{c}\text { Self-weight of } \\
\text { soil + HS-25 } \\
\operatorname{load}\left(V_{d++11}\right)\end{array}$ & \\
\hline \multirow{3}{*}{$18(0.45)$} & $10(3)$ & 0.1069 & 0.2849 & 167 \\
\hline & $20(6)$ & 0.2151 & 0.3535 & 64 \\
\hline & 50 (15) & 0.5391 & 0.6732 & 25 \\
\hline \multirow{3}{*}{$21(0.52)$} & $10(3)$ & 0.1244 & 0.3298 & 165 \\
\hline & $20(6)$ & 0.2529 & 0.39666 & 57 \\
\hline & 50 (15) & 0.6366 & 0.7722 & 21 \\
\hline \multirow{3}{*}{$24(0.60)$} & $10(3)$ & 0.1395 & 0.3669 & 163 \\
\hline & $20(6)$ & 0.2842 & 0.436 & 53 \\
\hline & 50 (15) & 0.7154 & 0.8502 & 19 \\
\hline
\end{tabular}

From Tables 7.4 and 7.5, the variation in deflection percentages indicates that the effect of live load decreases with an increase in backfill depth. At depths greater than 20 feet $(6 \mathrm{~m})$ the change in vertical deflection is not so significant. 


\subsection{Validation of the time-dependent model used for HDPE and PVC}

As an alternative to a comprehensive time-dependent creep analyses, static analyses were performed using the initial and fifty year modulus recommended by AASHTO (2007). An initial modulus of 110,000 psi and fifty year modulus of 22,000 psi was used for the HDPE pipe. For PVC pipes, initial modulus of 400,000 psi and fifty year modulus of 140,000 psi was used. The purposes of these analyses were to compare the initial and fifty year pipe deflections with the results obtained from the creep analyses. Table 7.6 shows the results for a 24 inch HDPE and PVC pipe installed in CLSM at a depth of 20 feet and trench width ratio of two. The results from such simplified finite element static analyses show similar results to those obtained from the comprehensive analyses.

Table 7.6: Compairision of Results from Static and Creep Analyses

\begin{tabular}{|c|c|c|c|c|}
\hline \multirow{2}{*}{ Pipe } & \multicolumn{4}{|c|}{ Deflection (inches) } \\
\cline { 2 - 5 } & \multicolumn{2}{|c|}{ Static Analyses } & \multicolumn{2}{c|}{ Creep Analyses } \\
\cline { 2 - 5 } & Initial & 50 years & Initial & 50 years \\
\hline HDPE & 0.136 & 0.190 & 0.139 & 0.166 \\
\hline PVC & 0.090 & 0.107 & 0.090 & 0.106 \\
\hline
\end{tabular}

\subsection{Numerical results for reinforced concrete (RCP) pipes}

Creep analyses were performed on a steel reinforced concrete pipes (RCP) of diameters 24 inch $(0.60 \mathrm{~m}), 48$ inch $(1.20 \mathrm{~m}), 72$ inch $(1.80 \mathrm{~m})$, and 96 inch $(2.40 \mathrm{~m})$. Fill heights of 10 feet $(3 \mathrm{~m}), 20$ feet $(6 \mathrm{~m})$, and 50 feet $(15 \mathrm{~m})$ were considered. In this section, the results obtained for a 96 inch $(2.40 \mathrm{~m})$ pipe are presented since it appears to be the worst-case scenario. A comparison of the performance of other pipe sizes is then presented. 


\subsubsection{Response due to self-weight of the sol}

The response of a 96 inch reinforced concrete pipe under self-weight of soil, different pipe backfill materials, and different trench widths are presented in this section. Figure 7.33 shows the fifty-year deformation contours of the pipe-soil system under selfweight of soil. The pipe is installed at a depth of 20 feet $(6 \mathrm{~m})$ with CLSM as the pipe backfill. Figure 7.34 shows the fifty-year vertical pipe deflections (expressed as a \%) of a 96 inch (2.40 m) reinforced concrete pipe installed in CLSM and granular stone. The pipe is installed at a depth of 50 feet $(15 \mathrm{~m})$ in a trench width equal to two times the mean diameter of the pipe. The pipe deflections were computed by taking the difference between the magnitudes of vertical displacement at the crown and base of the pipe.

Figure 7.34 shows the comparison of pipe deflections under different pipe backfill materials. The magnitude of vertical pipe deflections was higher when granular stone was used as pipe backfill. From Figure 7.35 and Figure 7.36, it can be seen that the vertical pipe deflection increased with an increase in backfill height. Under the same boundary and loading conditions, pipe deflections were too small when compared to those obtained for the plastic pipe materials (HDPE and PVC). Figure 7.37 and Figure 7.38 show the influence of trench width on the vertical deflection of a pipe installed in CLSM and granular stone, respectively. The change in pipe deflections with variation in trench width was very small. Also, Figures 7.37 and 7.38 illustrate that a 96 inch $(2.40 \mathrm{~m})$ reinforced concrete pipe can be installed up to a depth of 50 feet $(15 \mathrm{~m})$ with the trench width ratio as small as 1.5 without causing a pipe failure. 

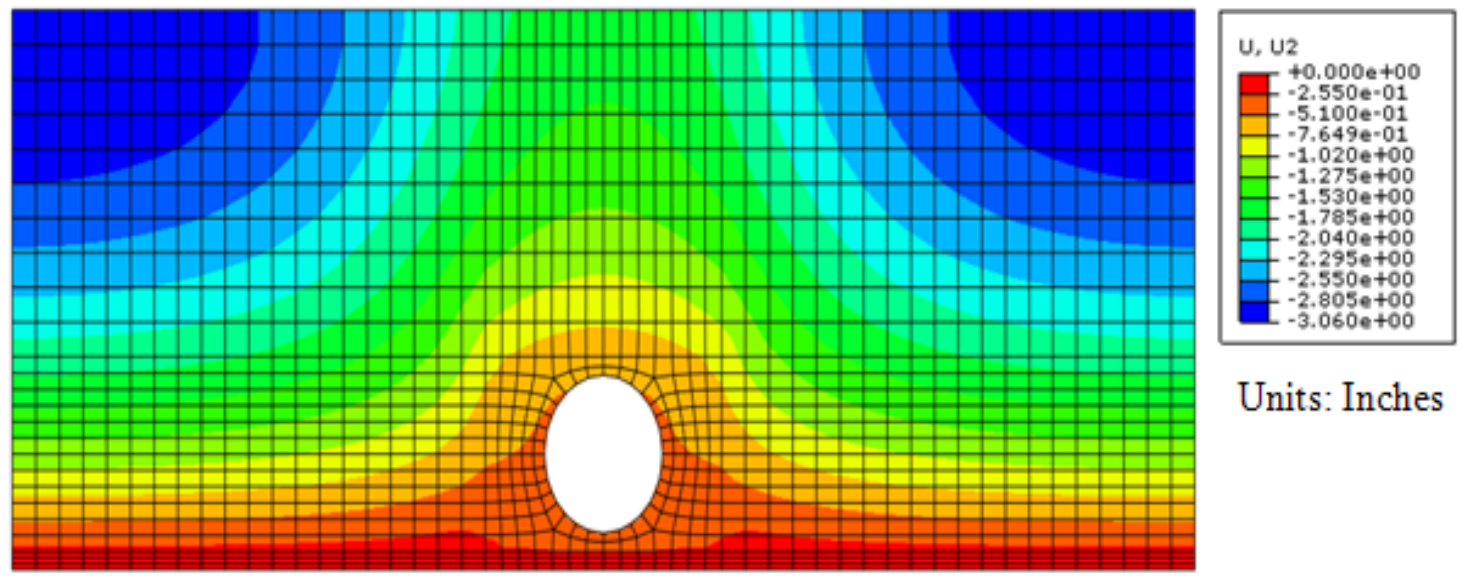

Units: Inches

Figure 7.33: Fifty-year deformation in the soil-pipe system due to self-weight of the soil.

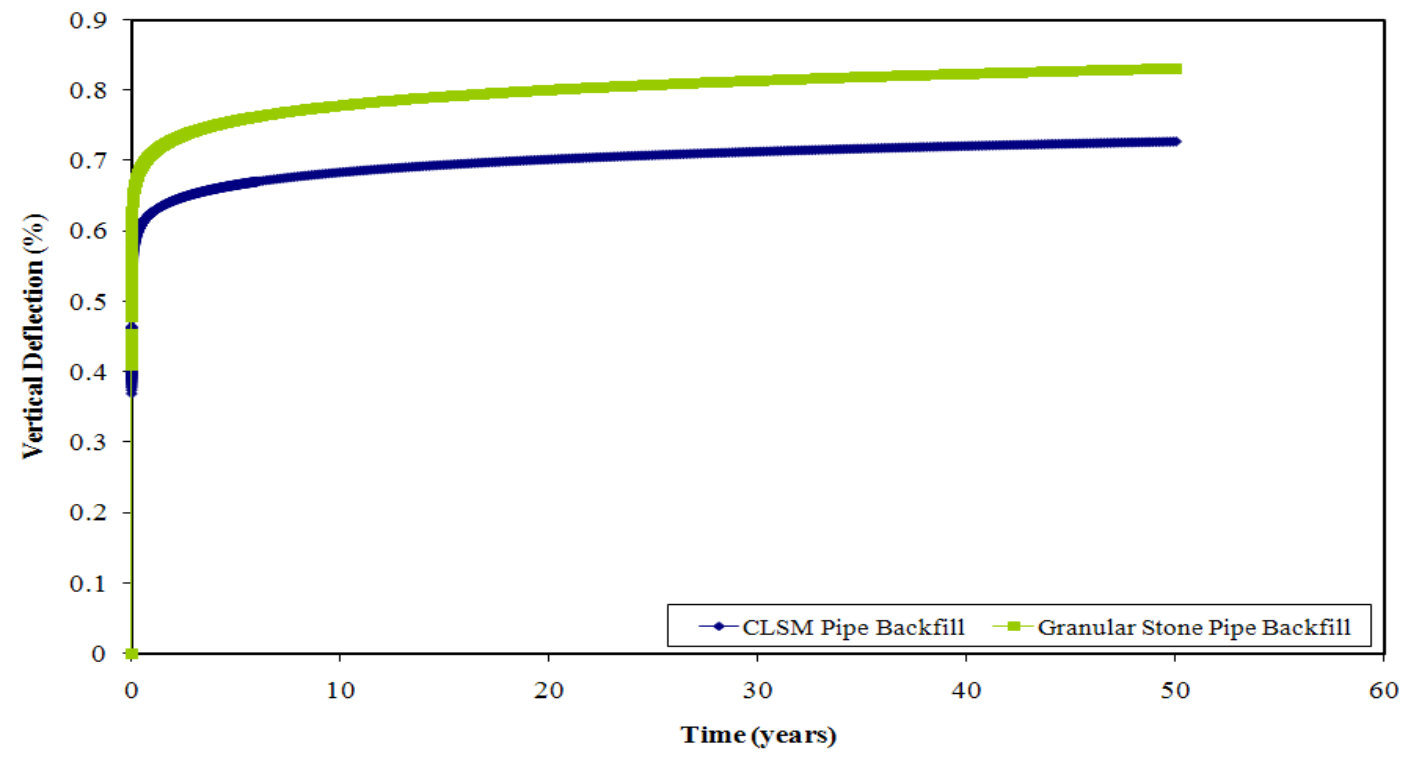

Figure 7.34: Fifty-year vertical pipe deflection of a 96 inch $(2.40 \mathrm{~m})$ reinforced concrete pipe installed at a depth of 50 feet $(15 \mathrm{~m})$. 


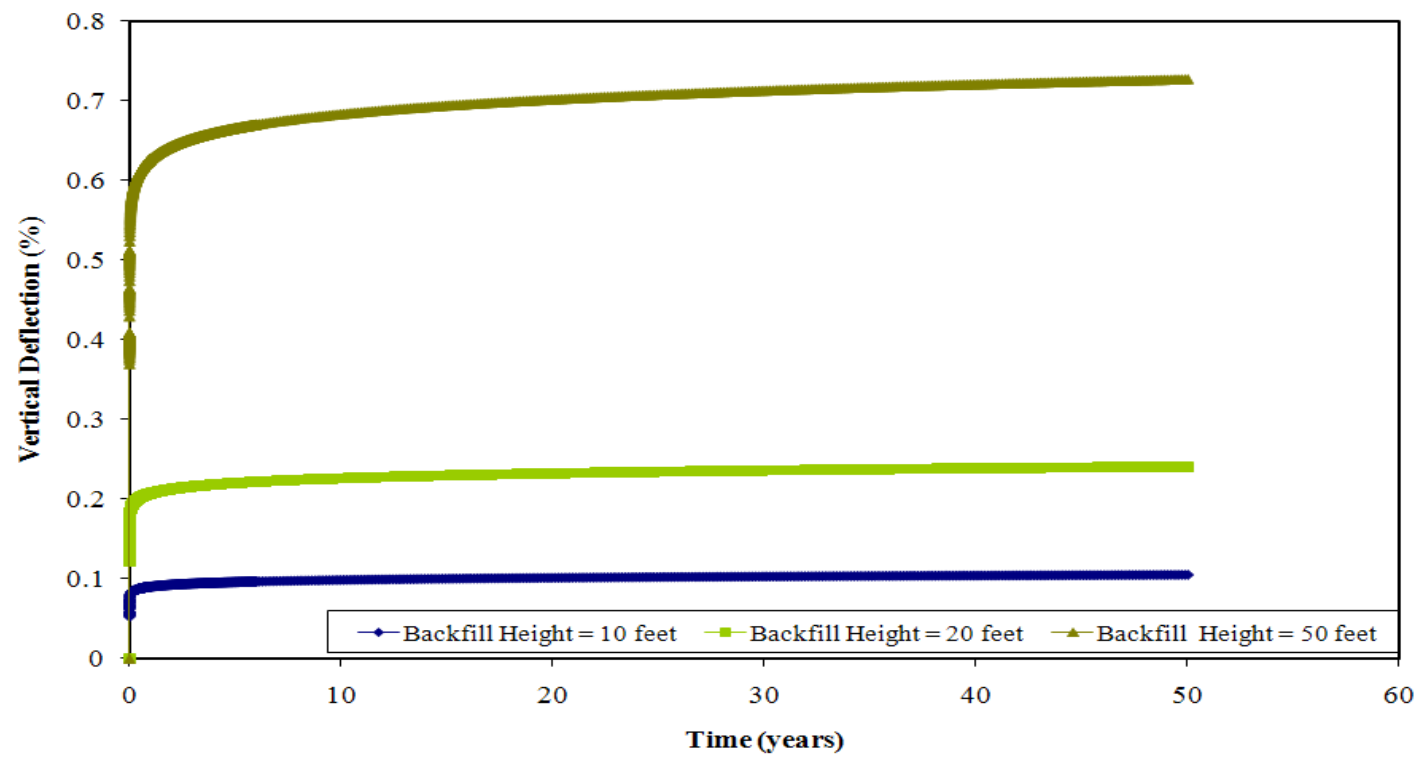

Figure 7.35: Vertical deflections of a 96 inch $(2.40 \mathrm{~m})$ reinforced concrete pipe installed in CLSM.

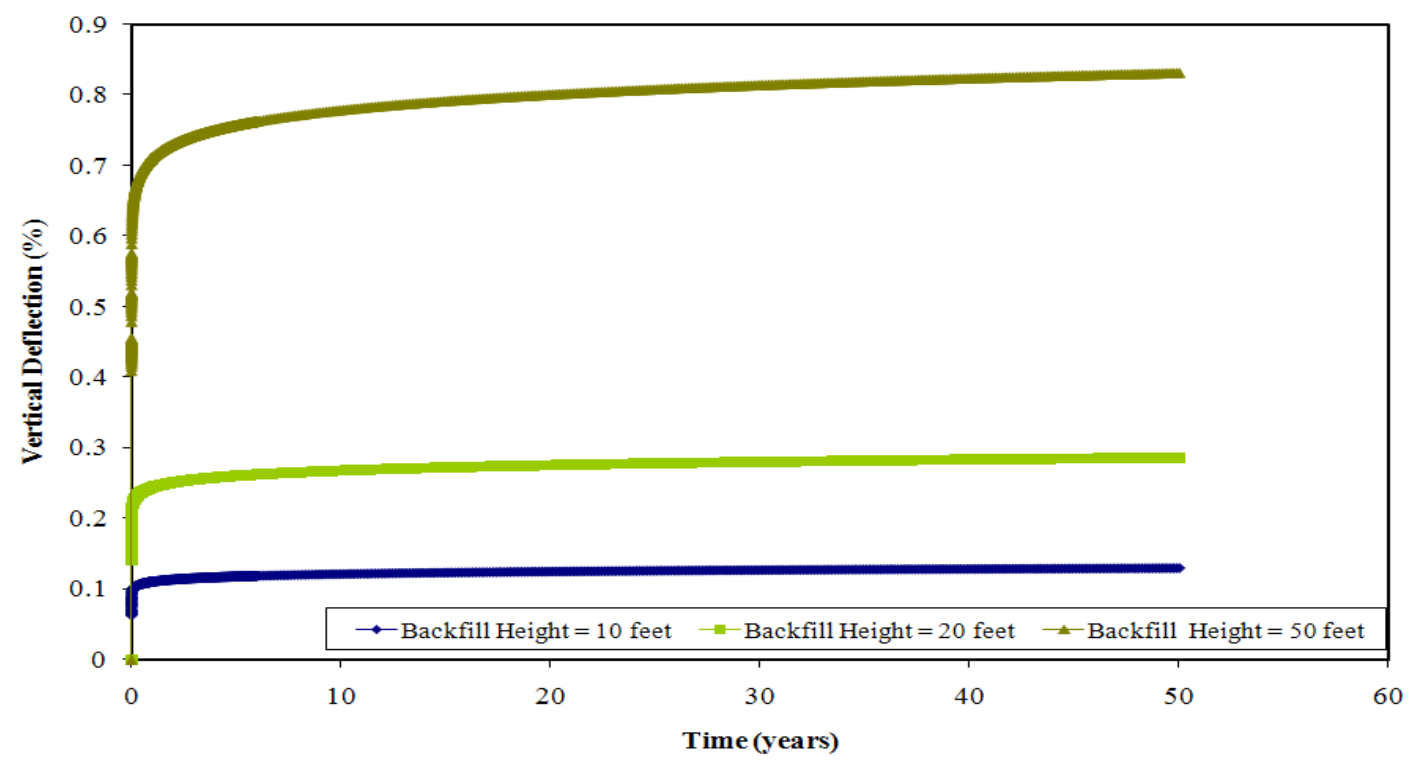

Figure 7.36: Vertical deflections of a 96 inch $(2.40 \mathrm{~m})$ reinforced concrete pipe installed in granular stone. 


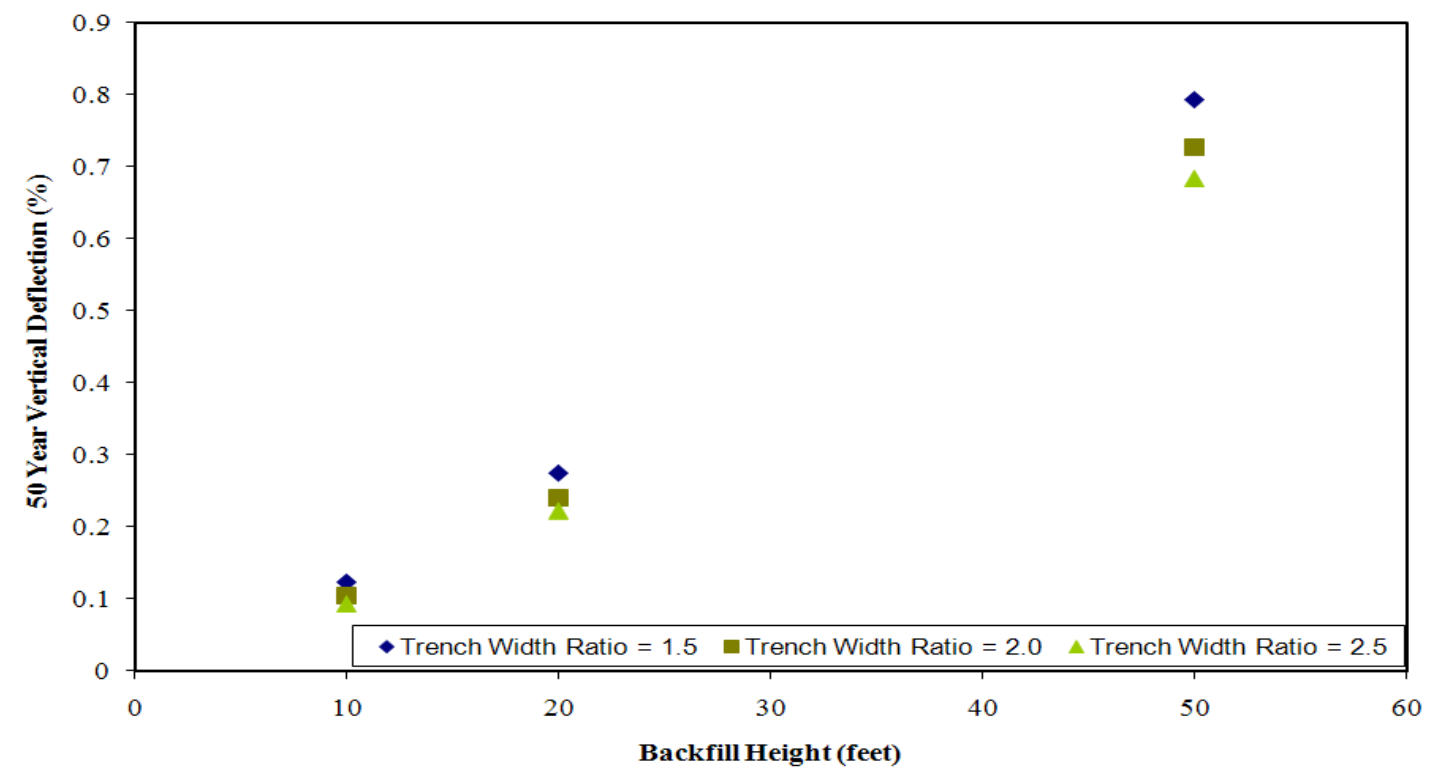

Figure 7.37: Effect of trench width on the vertical deflection of a 96 inch $(2.40 \mathrm{~m})$ reinforced concrete pipe installed in CLSM .

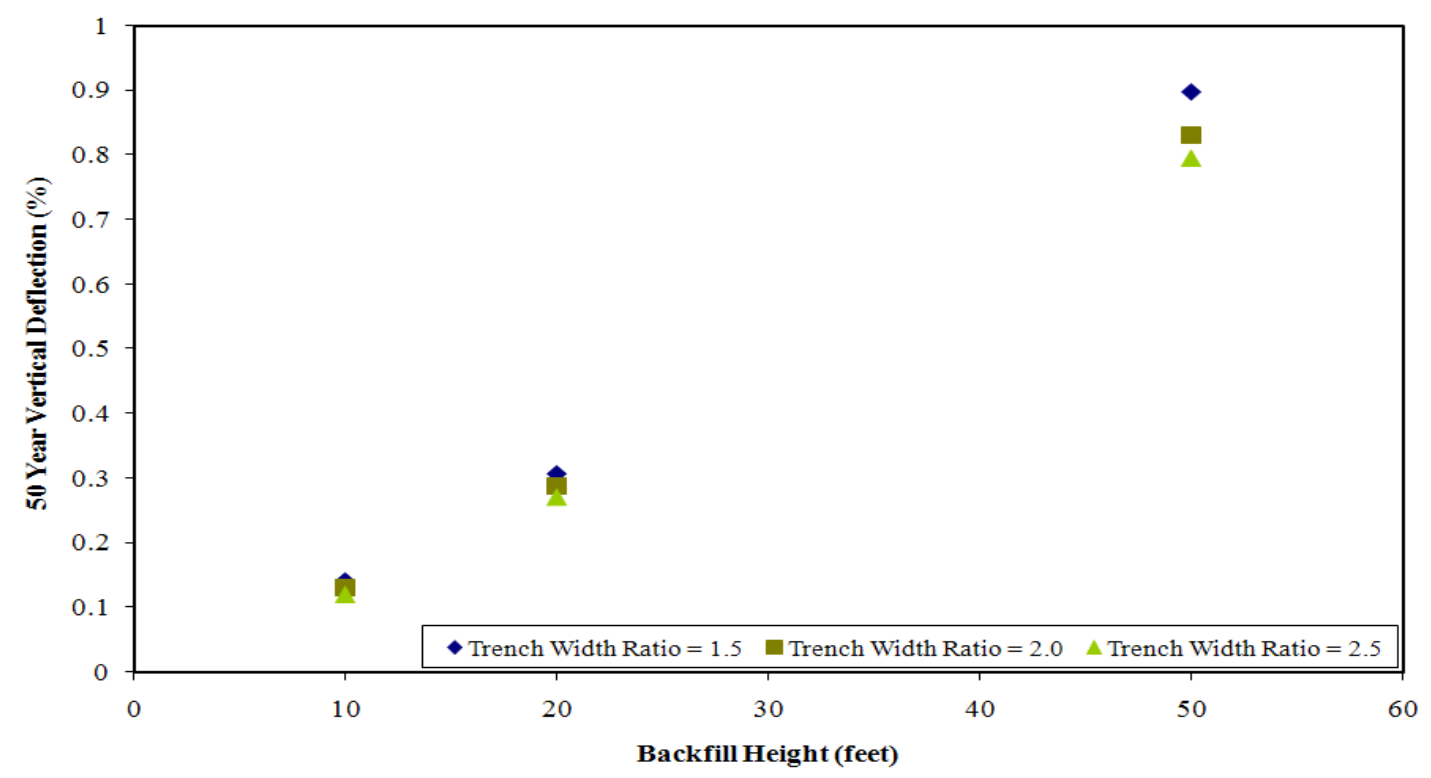

Figure 7.38: Effect of trench width on the vertical deflection of a 96 inch $(2.40 \mathrm{~m})$ reinforced concrete pipe installed in granular stone.

The deformations of pipes with various diameters installed under different fill heights and CLSM are shown in Figure 7.39. The deformations of pipes with various diameters installed under different fill heights and granular stone are shown in Figure 
7.40. The trench width in this case is equal to two times the mean diameter of the pipe. The results illustrate that the deflection trend is similar for all pipe diameters. The vertical deflections were slightly higher when granular stone is used as backfill, which is similar to what was presented earlier.

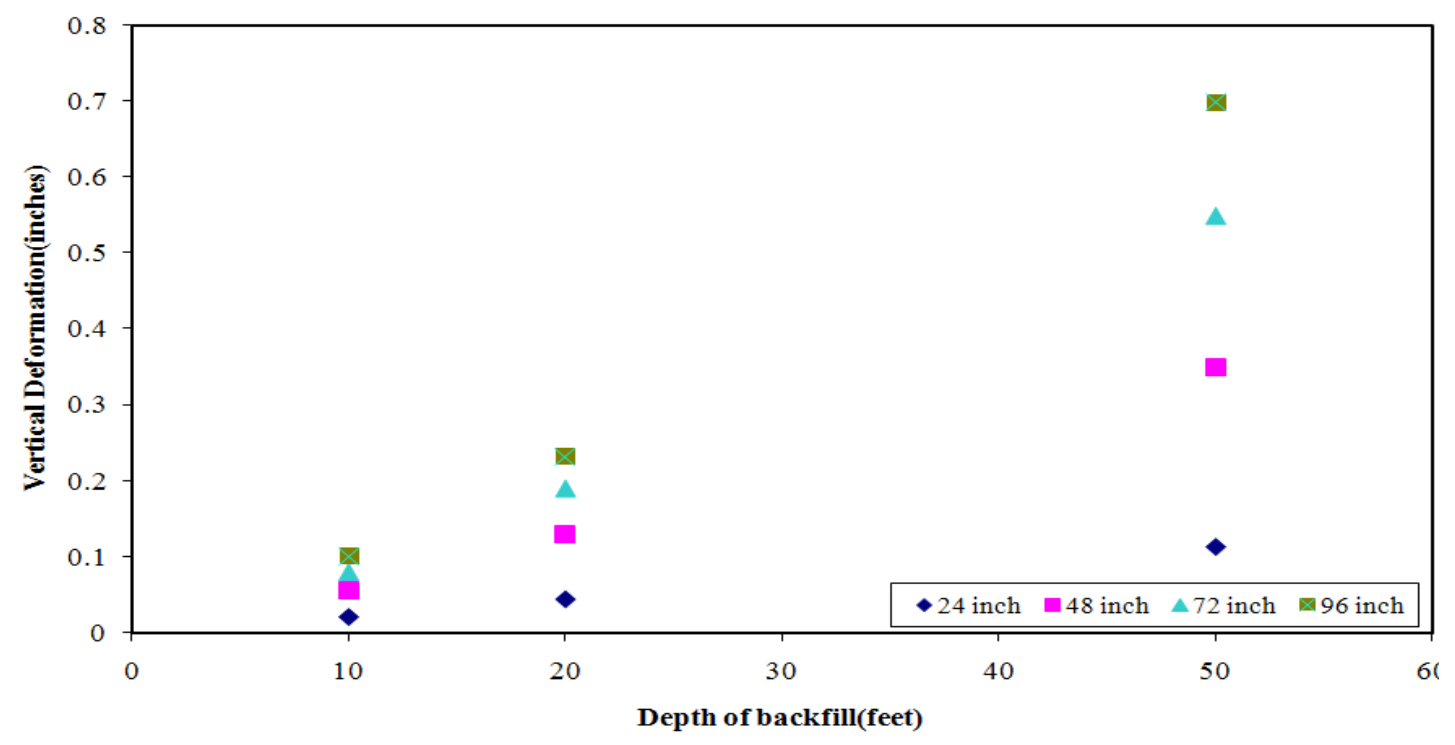

Figure 7.39: Fifty-year vertical deformation of var ious reinforced concrete pipe diameters installed in CLSM.

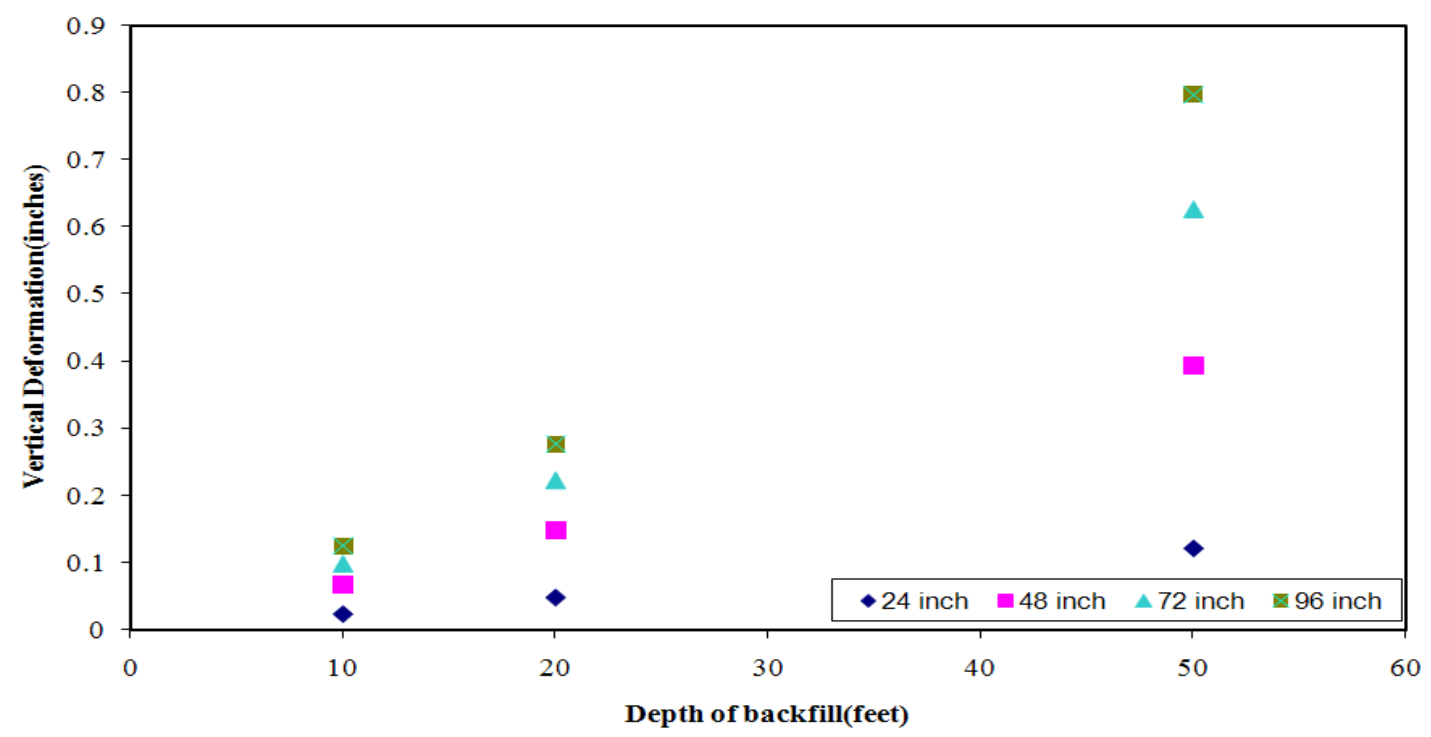

Figure 7.40: Fifty-year vertical deformation of various reinforced concrete pipe diameters installed in granular stone. 


\subsubsection{Response due to HS $\mathbf{- 2 5}$ truck loading + self-weight of the soil}

Figure 7.41 shows the fifty-year vertical pipe deformation contours of a 96 inch ( $2.40 \mathrm{~m}$ ) reinforced concrete pipe. The pipe is installed in CLSM at a depth of 20 feet (6 m). The loads considered are the HS-25 truck load and the self-weight of the soil. Figure 7.42 shows the vertical pipe deflections (expressed as a \%) of a 96 inch $(2.40 \mathrm{~m})$ reinforced concrete pipe installed in CLSM and granular stone. The pipe is installed at a depth of 50 feet $(15 \mathrm{~m})$ in a trench width equal to two times the mean diameter of the pipe. The pipe deflections were computed by taking the difference between the magnitudes of vertical displacement at the crown and base of the pipe.

Figure 7.42 shows a comparison of pipe deflections under different pipe backfill materials. Figure 7.42 shows that beyond one year of installation the creep deformation was just $20 \%-40 \%$ of the total deflection. It can be seen that the magnitude of vertical deflection is higher when granular stone is used as pipe backfill. Figure 7.43 and Figure 7.44 show the percentage vertical deflection of a 96 inch $(2.40 \mathrm{~m})$ reinforced concrete pipe installed in CLSM and granular stone, respectively. The vertical pipe deflections increased with an increase in backfill height. Figure 7.45 and Figure 7.46 show the influence of trench width on the vertical deflection of the pipe installed in CLSM and granular stone, respectively. Pipe deflections decreased with an increase in trench width. Also, Figures 7.45 and 7.46 illustrate that a 96 inch $(2.40 \mathrm{~m})$ reinforced concrete pipe can be installed up to 50 feet $(15 \mathrm{~m})$ with the trench width ratio as small as 1.5 without causing a pipe failure. 

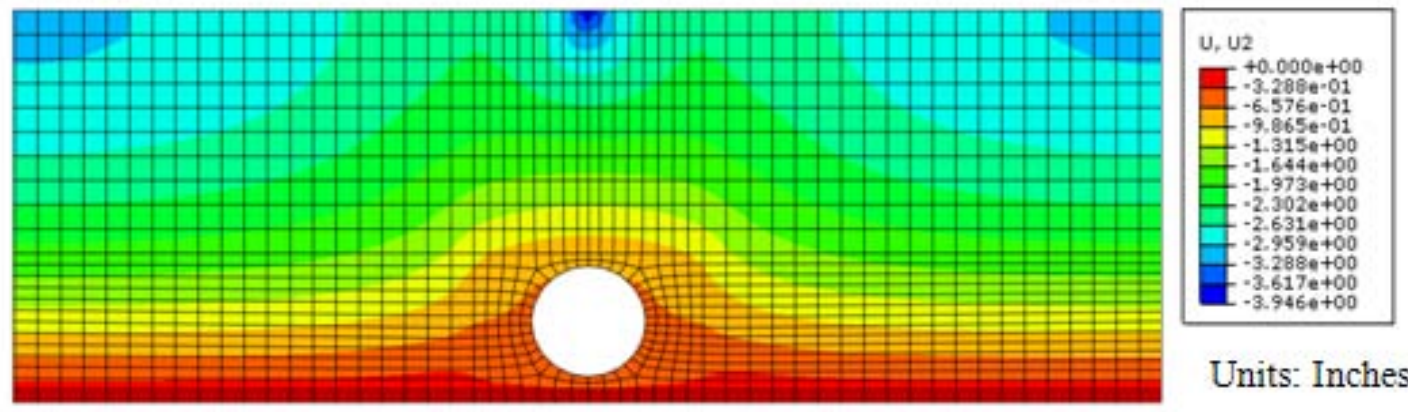

Units: Inches

Figure 7.41: Fifty-year deformation in the soil-pipe system under HS-25 truck loading.

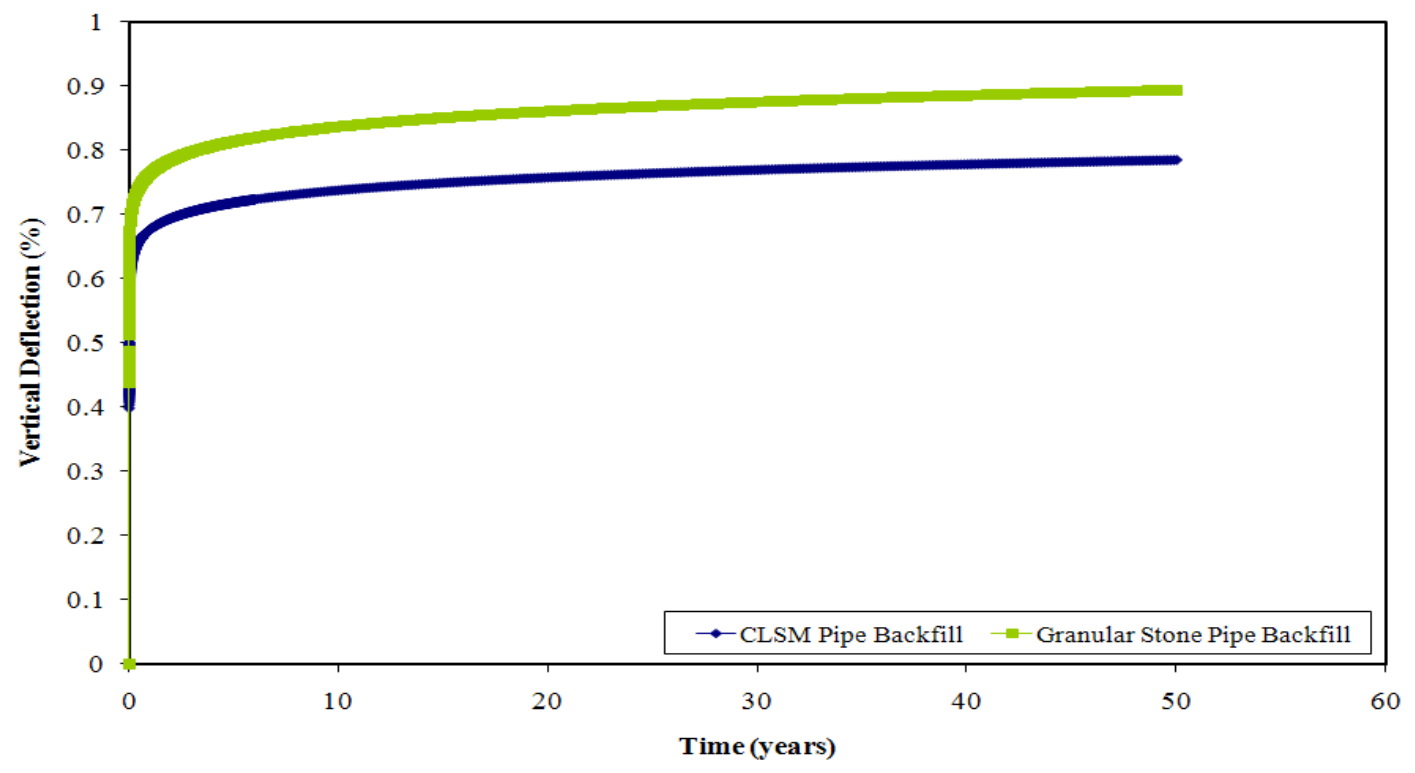

Figure 7.42: Fifty-year vertical pipe deflection due to HS-25 loading and self-weight of soil. 


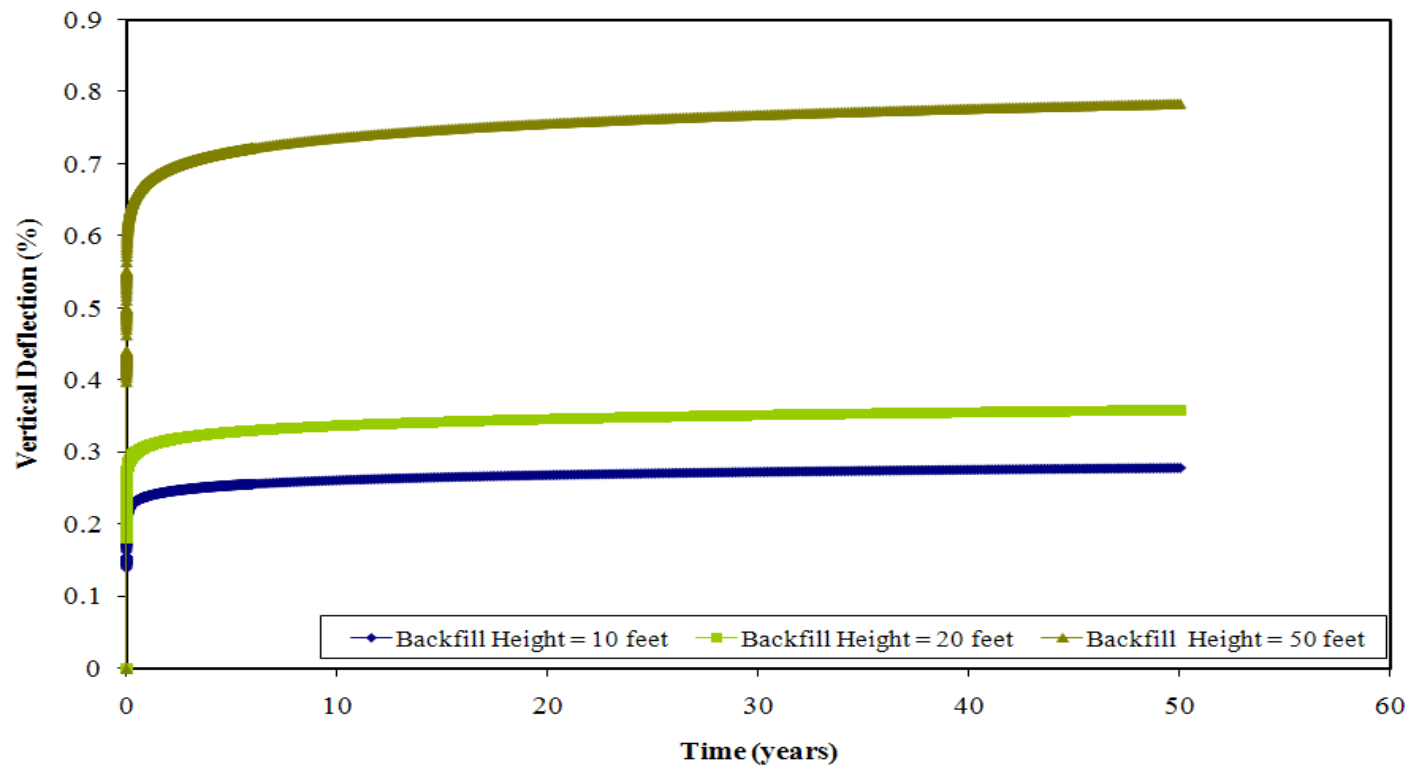

Figure 7.43: Vertical deflections of a 96 inch $(2.40 \mathrm{~m})$ reinforced concrete pipe installed in CLSM under HS-25 load and self-weight of soil.

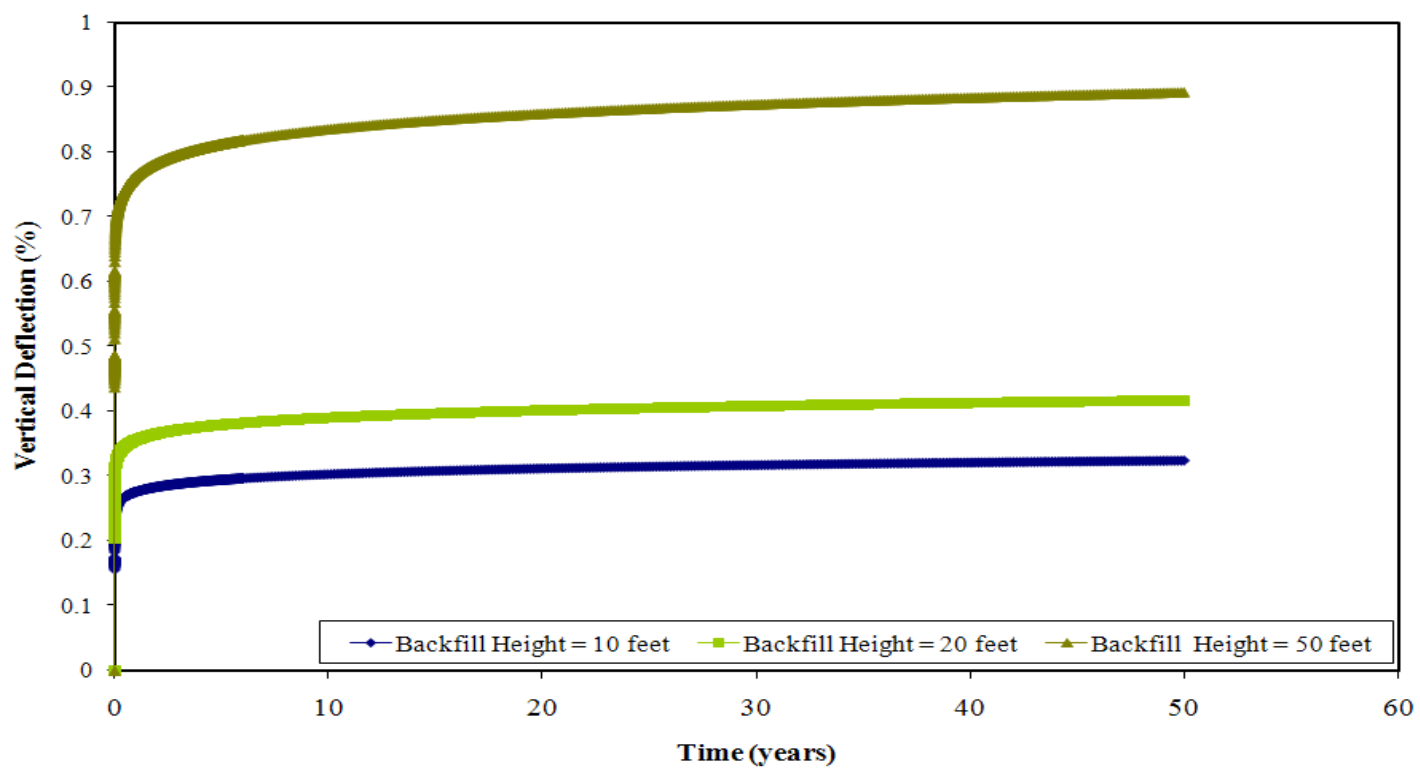

Figure 7.44: Vertical deflections of a 96 inch $(2.40 \mathrm{~m})$ reinforced concrete pipe installed in granular stone under HS-25 load and self-weight of soil. 


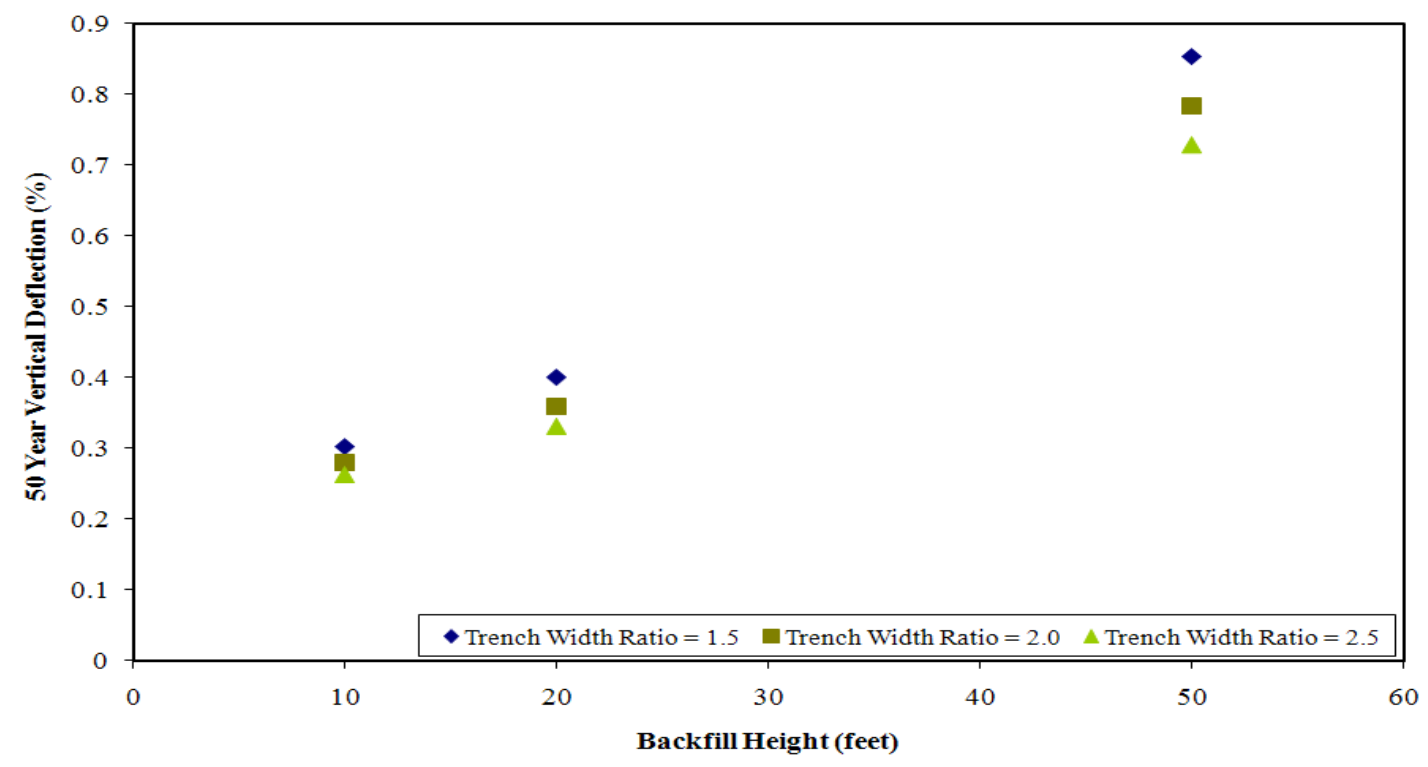

Figure 7.45: Effect of trench width ratio on the vertical deflections of a 96 inch $(2.40 \mathrm{~m})$ reinforced concrete pipe installed in CLSM under HS-25 load and self-weight of soil.

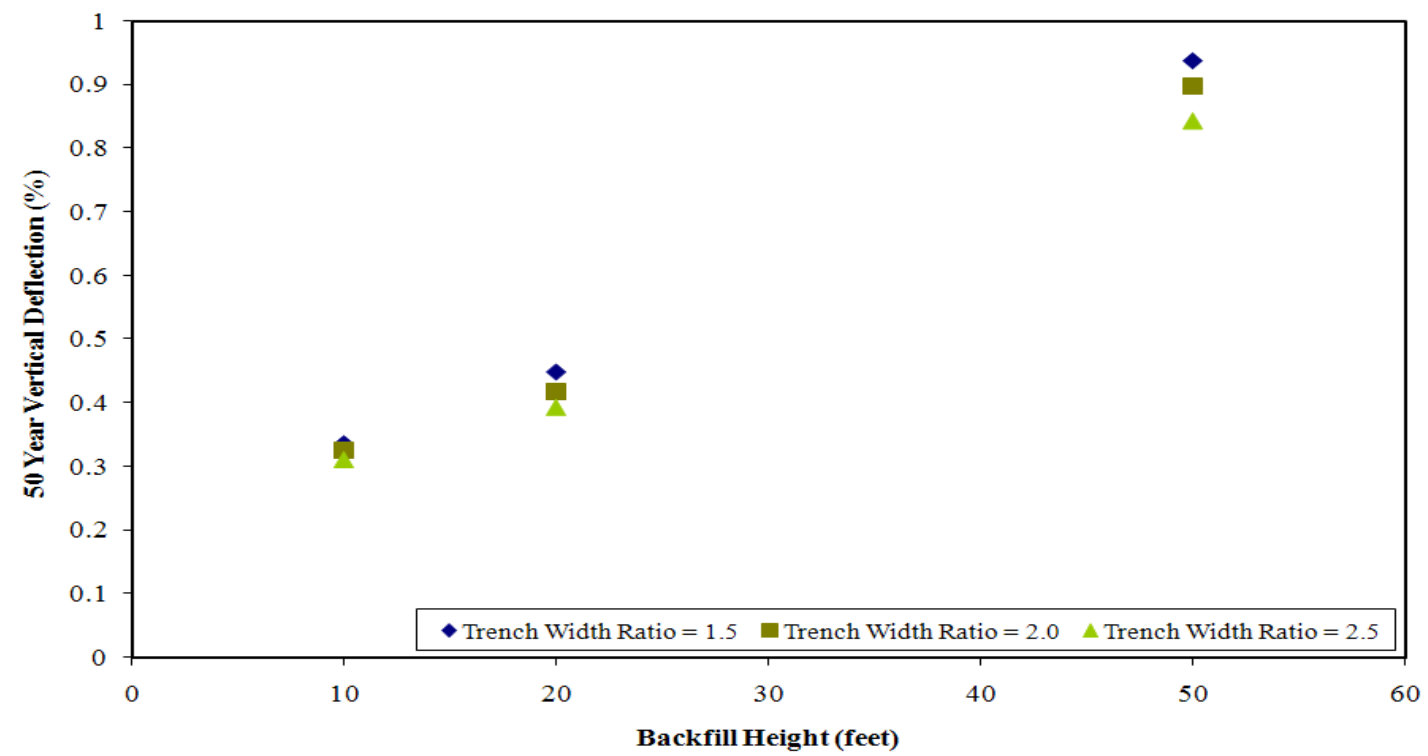

Figure 7.46: Effect of trench width ratio on the vertical deflections of a 96 inch $(2.40 \mathrm{~m})$ reinforced concrete pipe installed in granular stone under HS-25 load and self-weight of soil. 
The deformation of pipes with various diameters installed under different fill heights and CLSM are shown in Figure 7.47. The deformation of pipes with various diameters installed under different fill heights and granular stone are shown in Figure 7.48. The trench width in these cases is equal to two times the mean diameter of the pipe. Results show that the deflection trend is similar for all pipe diameters. The vertical deformations were slightly higher (can be said to be insignificant) when granular stone was used as backfill. Tables 7.7 and 7.8 present the comparison between the pipe deflections due to self-weight of soil and self-weight of soil plus HS-25 loads under CLSM and granular stone backfill, respectively. 


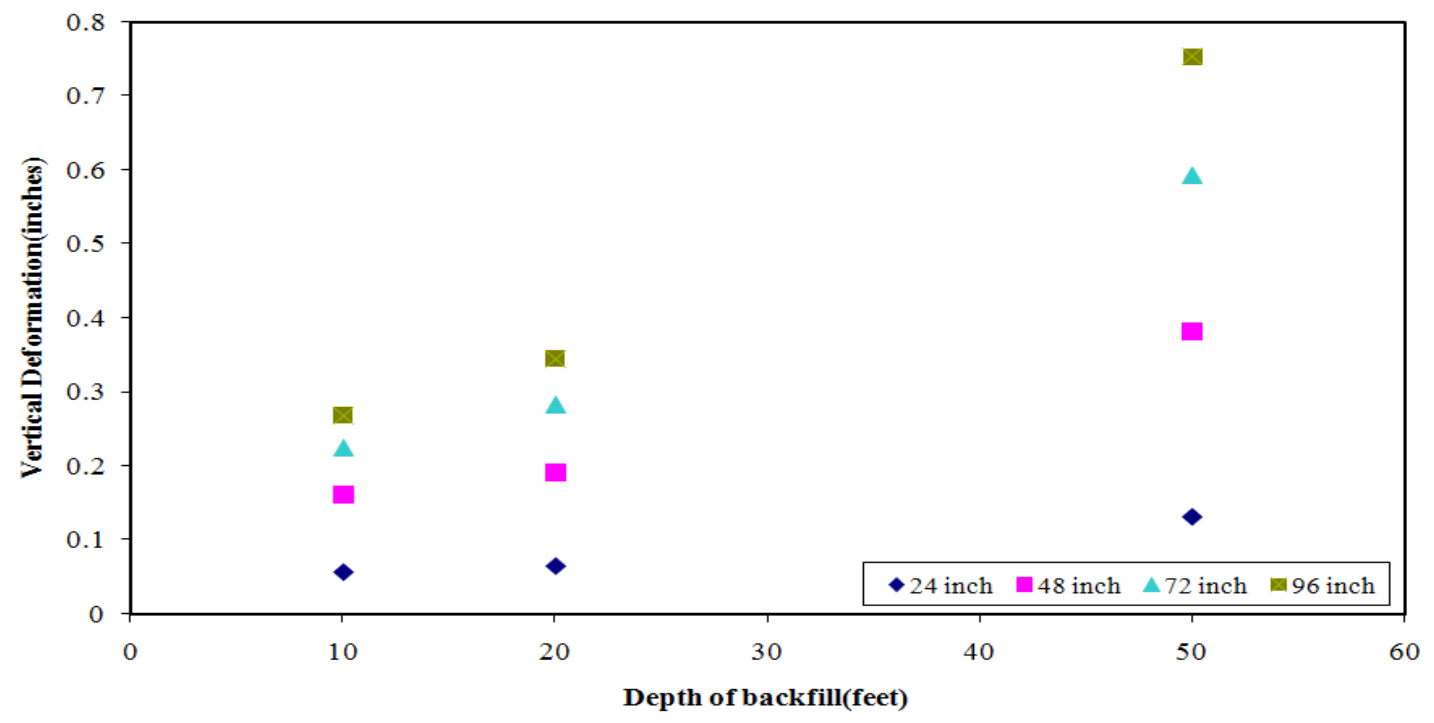

Figure 7.47: Fifty-year vertical deformation of various reinforced concrete pipe diameters installed in CLSM under HS-25 loads and self-weight of soil.

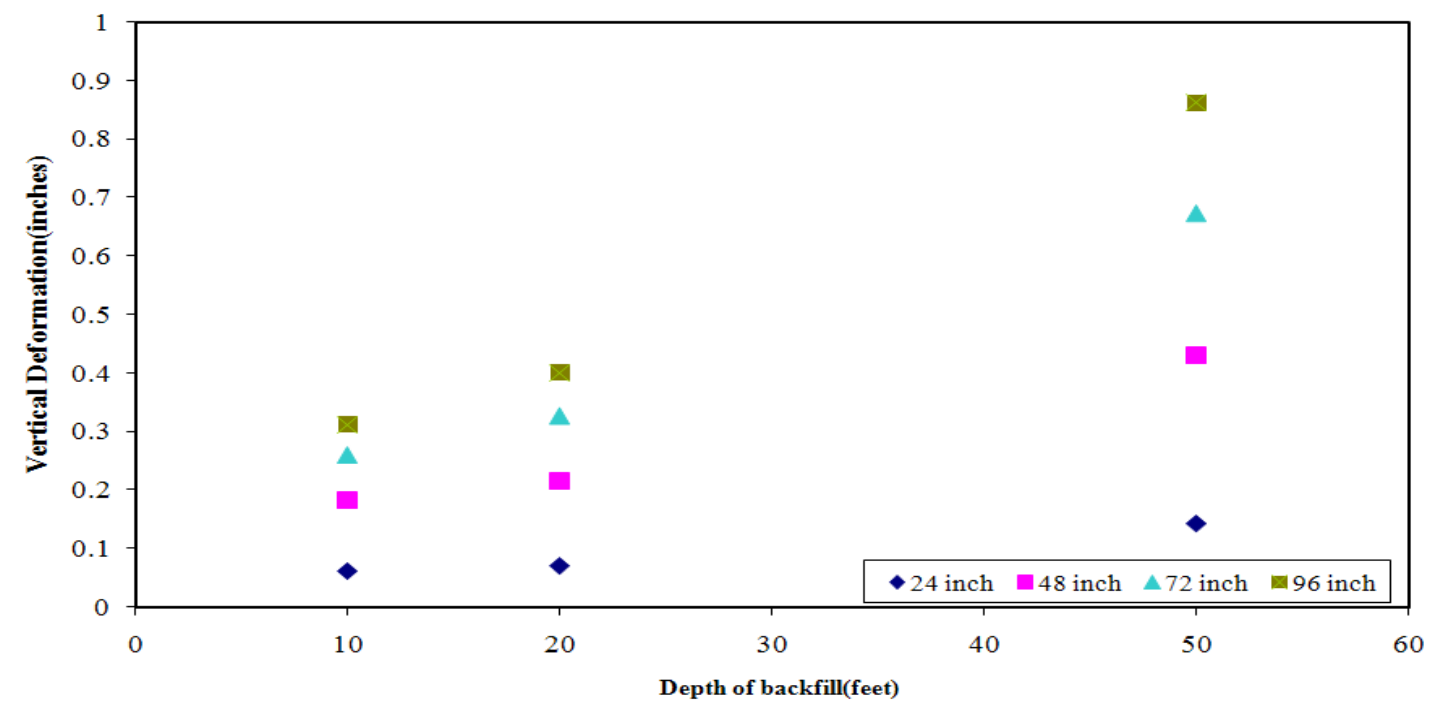

Figure 7.48:Fifty-year vertical deformation of various reinforced concrete pipe diameters in granular stone under HS-25 loads and self-weight of soil. 
Table 7.7: Fifty-Year Vertical Deflection of Reinforced Concrete Pipes Installed in CLSM

\begin{tabular}{|c|c|c|c|c|}
\hline \multirow[b]{2}{*}{$\begin{array}{c}\text { Pipe Diameter } \\
\text { inches (m) }\end{array}$} & \multirow[b]{2}{*}{$\begin{array}{c}\text { Backfill } \\
\text { Depth } \\
\text { feet }(m)\end{array}$} & \multicolumn{2}{|c|}{ Vertical Deflection (inches) } & \multirow[b]{2}{*}{$\begin{array}{l}\text { Percentage increases in } \\
\text { deflection }(\%) \\
\left(\frac{\left(\mathrm{V}_{\mathrm{dl}+\mathrm{II}-} \mathrm{V}_{\mathrm{dl}}\right)}{\mathrm{V}_{\mathrm{dl}}}\right) * 100\end{array}$} \\
\hline & & $\begin{array}{l}\text { Self-weight } \\
\text { of soil }\left(V_{d l}\right)\end{array}$ & $\begin{array}{c}\text { Self-weight } \\
\text { of soil }+ \\
\text { HS-25 load } \\
\left(V_{d l+l l}\right)\end{array}$ & \\
\hline \multirow{3}{*}{$24(0.6)$} & $10(3)$ & 0.0210 & 0.0578 & 175 \\
\hline & $20(6)$ & 0.0442 & 0.066 & 49 \\
\hline & $50(15)$ & 0.1129 & 0.1321 & 17 \\
\hline \multirow{3}{*}{$48(1.2)$} & $10(3)$ & 0.0565 & 0.1611 & 185 \\
\hline & $20(6)$ & 0.1297 & 0.192 & 48 \\
\hline & $50(15)$ & 0.35 & 0.383 & 9 \\
\hline \multirow{3}{*}{$72(1.8)$} & $10(3)$ & 0.0811 & 0.2244 & 177 \\
\hline & $20(6)$ & 0.191 & 0.283 & 48 \\
\hline & $50(15)$ & 0.549 & 0.594 & 8 \\
\hline \multirow{3}{*}{$96(2.4)$} & $10(3)$ & 0.1007 & 0.2684 & 167 \\
\hline & $20(6)$ & 0.2315 & 0.3448 & 49 \\
\hline & $50(15)$ & 0.6985 & 0.7534 & 8 \\
\hline
\end{tabular}


Table 7.8: Fifty-Year Vertical Deflection of Reinforced Concrete Pipes Installed in Granular Stone

\begin{tabular}{|c|c|c|c|c|}
\hline \multirow[b]{2}{*}{$\begin{array}{l}\text { Pipe Diameter } \\
\text { inches (m) }\end{array}$} & \multirow[b]{2}{*}{$\begin{array}{l}\text { Backfill } \\
\text { Depth } \\
\text { feet }(m)\end{array}$} & \multicolumn{2}{|c|}{ Vertical Deflection (inches) } & \multirow{2}{*}{$\begin{array}{l}\text { Percentage increases in } \\
\text { deflection (\%) } \\
\left(\frac{\left(\mathrm{V}_{\mathrm{dl}+\mathrm{Il}-} \mathbf{V}_{\mathrm{dl}}\right)}{\mathrm{V}_{\mathrm{dl}}}\right) * 100\end{array}$} \\
\hline & & $\begin{array}{l}\text { Self-weight } \\
\text { of soil }\left(V_{d l}\right)\end{array}$ & $\begin{array}{c}\text { Self-weight of } \\
\text { soil + HS-25 } \\
\operatorname{load}\left(\mathbf{V}_{\mathrm{d}++\mathrm{II}}\right)\end{array}$ & \\
\hline \multirow{3}{*}{$24(0.6)$} & $10(3)$ & 0.0229 & 0.0629 & 175 \\
\hline & $20(6)$ & 0.0478 & 0.0718 & 50 \\
\hline & $50(15)$ & 0.1216 & 0.1431 & 18 \\
\hline \multirow{3}{*}{$48(1.2)$} & $10(3)$ & 0.0666 & 0.1843 & 176 \\
\hline & $20(6)$ & 0.1486 & 0.2180 & 47 \\
\hline & $50(15)$ & 0.3949 & 0.4322 & 9 \\
\hline \multirow{3}{*}{$72(1.8)$} & $10(3)$ & 0.0986 & 0.2612 & 165 \\
\hline & $20(6)$ & 0.2231 & 0.3280 & 47 \\
\hline & $50(15)$ & 0.627 & 0.6743 & 8 \\
\hline \multirow{3}{*}{$96(2.4)$} & $10(3)$ & 0.1249 & 0.3120 & 150 \\
\hline & $20(6)$ & 0.2770 & 0.4015 & 45 \\
\hline & $50(15)$ & 0.7981 & 0.8621 & 8 \\
\hline
\end{tabular}

From Tables 7.7 and 7.8, the variation in deflection percentages indicates that the effect of live load decreases with an increase in backfill depth. At depths greater than 20 feet $(6 \mathrm{~m})$ the change in vertical deflection is not so significant.

\subsection{Numerical results for corrugated steel (CSP) pipes}

Creep analyses were performed on corrugated steel pipes (CSP) of diameter 48 inch $(1.20 \mathrm{~m}), 72$ inch $(1.80 \mathrm{~m}), 96$ inch $(2.40 \mathrm{~m})$, and 120 inch $(3 \mathrm{~m})$. Fill heights of 10 feet $(3 \mathrm{~m}), 20$ feet $(6 \mathrm{~m})$, and 50 feet $(15 \mathrm{~m})$ were considered. In this section, only the 
results of a 120 inch $(3 \mathrm{~m})$ pipe are presented since it appears to be the worst-case scenario. A comparison of the performance of other pipe sizes is then presented.

\subsubsection{Response due to self-weight of the soil}

The response of a 120 inch $(3 \mathrm{~m})$ corrugated steel pipe under self-weight of soil, different pipe backfill materials, and different trench widths are presented in this section. Figure 7.49 shows the instantaneous deformation contours of the pipe-soil system under self-weight of soil. The pipe is installed at a depth of 20 feet $(6 \mathrm{~m})$ with CLSM as the pipe backfill. Figure 7.50 shows the instantaneous vertical pipe deflections (expressed as a \%) of a 120 inch (3m) corrugated steel pipe installed in CLSM and granular stone. The pipe is installed at a depth of 50 feet $(15 \mathrm{~m})$ in a trench width equal to two times the mean diameter of the pipe. The pipe deflections were computed by taking the difference between the magnitudes of vertical displacement at the crown and base of the pipe.

Figure 7.50 shows a comparison of instantaneous pipe deflections under different pipe backfill materials. It is observed that the magnitude of vertical pipe deflections are higher when granular stone is used as pipe backfill. From Figure 7.51 and Figure 7.52, it can be seen that there is an increase in vertical pipe deflections with an increase in backfill height. Figure 7.53 and Figure 7.54 show the influence of trench width on the vertical pipe deflection of the pipe installed in CLSM and granular stone, respectively. The change in pipe deflections with variation in trench width was significant. Also, Figure 7.53 and Figure 7.54 illustrate that a 120 inch $(3 \mathrm{~m}$ ) corrugated steel pipe can be installed up to a depth of 50 feet $(15 \mathrm{~m})$ with the trench width ratio as small as 1.5 without causing a pipe failure. 

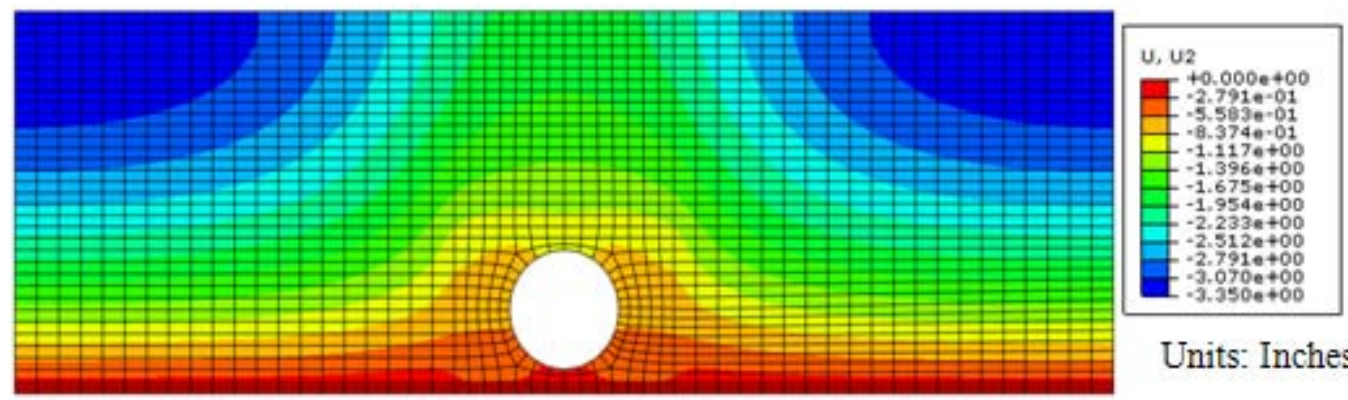

Units: Inches

Figure 7.49: Instantaneous deformation in the soil-pipe system due to self-weight of the soil.

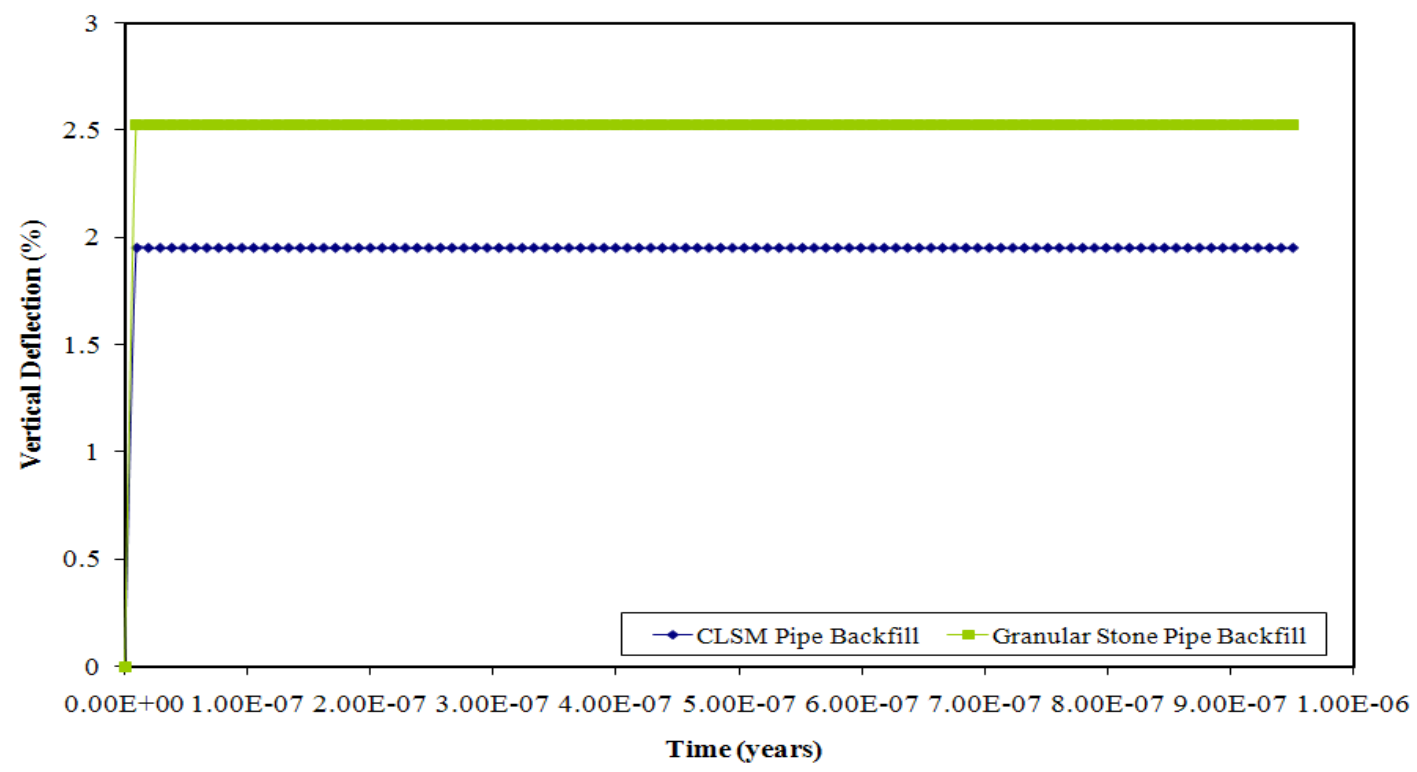

Figure 7.50: Instantaneous vertical pipe deflection of a 120 inch (3 m) corrugated steel pipe installed at a depth of 50 feet $(15 \mathrm{~m})$. 


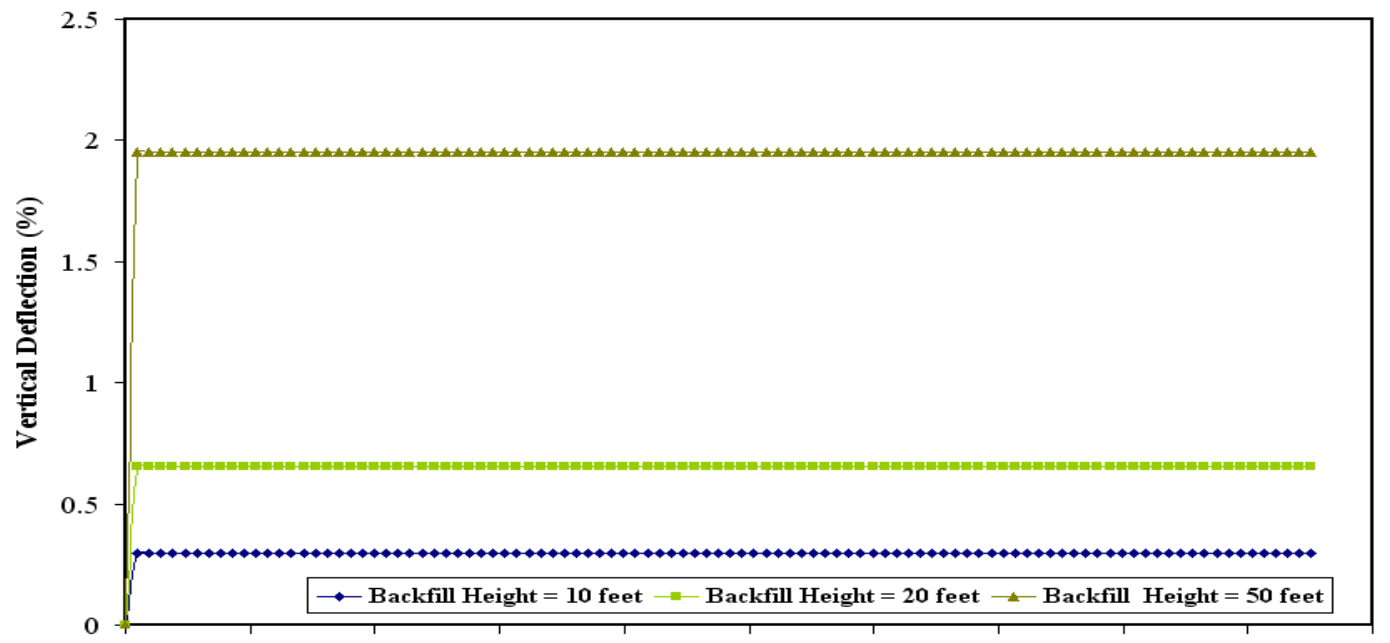

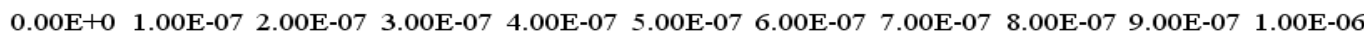
0

Time (years)

Figure 7.51: Instantaneous vertical deflections of a 120 inch $(3 \mathrm{~m})$ corrugated steel pipe installed in CLSM .

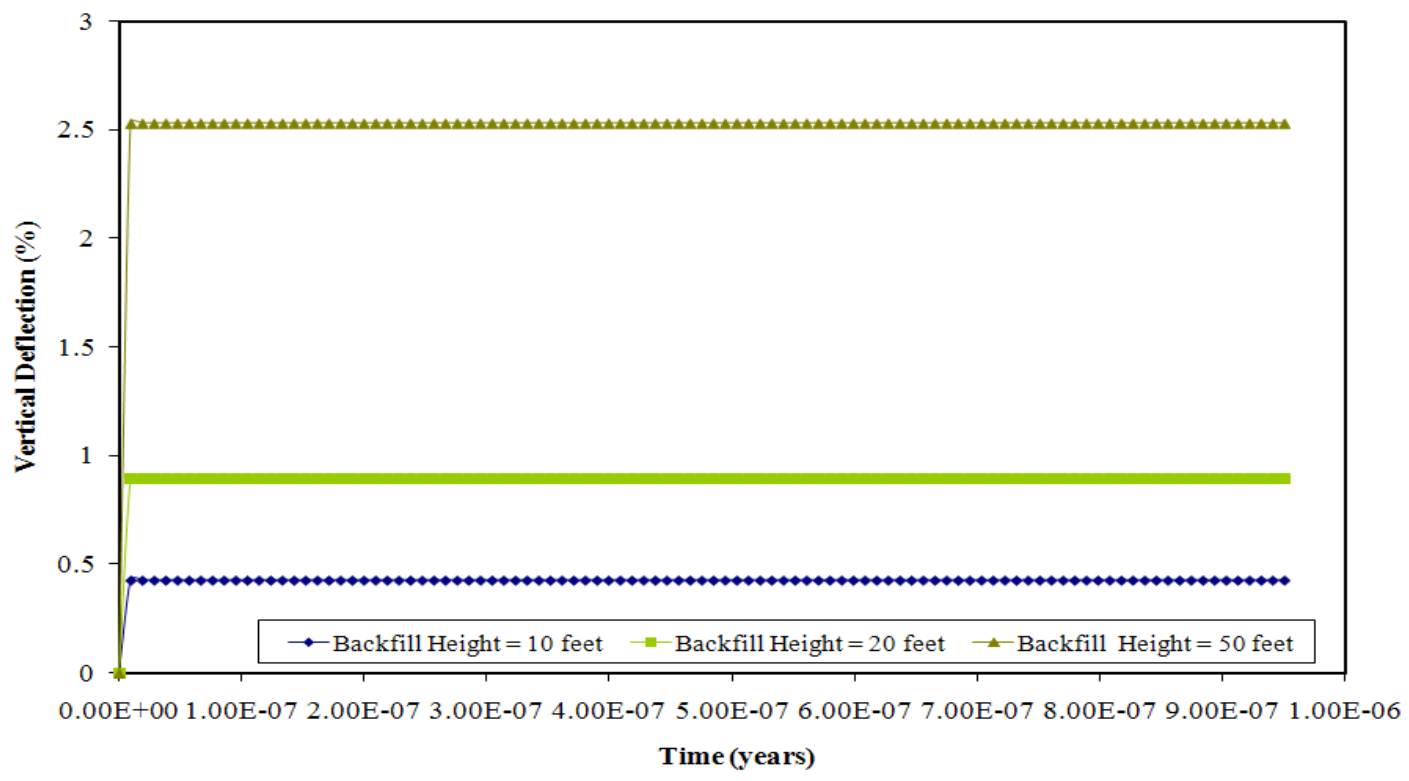

Figure 7.52: Instantaneous vertical deflections of a 120 inch $(3 \mathrm{~m})$ corrugated steel pipe installed in granular stone. 


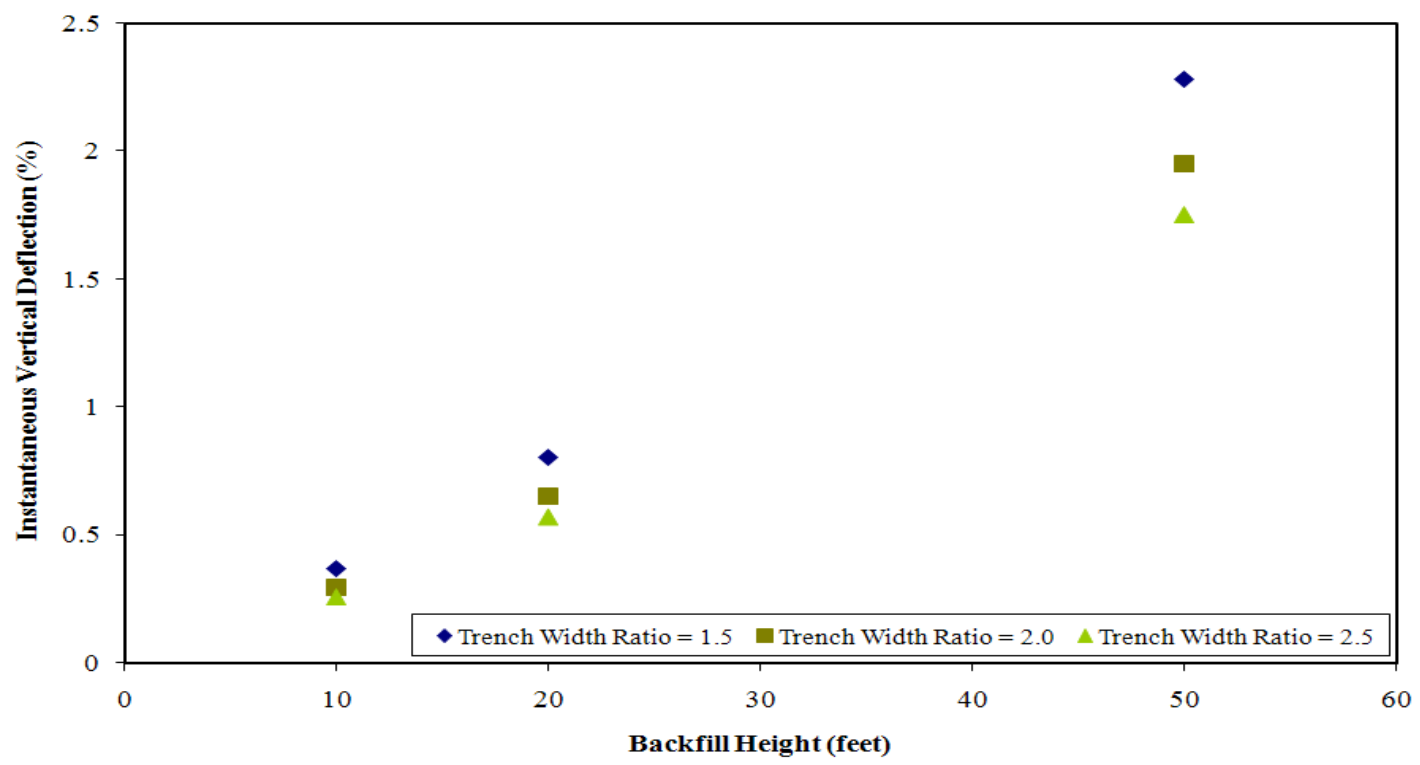

Figure 7.53:Effect of trench width on the vertical pipe deflection of a 120 inch $(3 \mathrm{~m})$ corrugated steel pipe installed in CLSM.

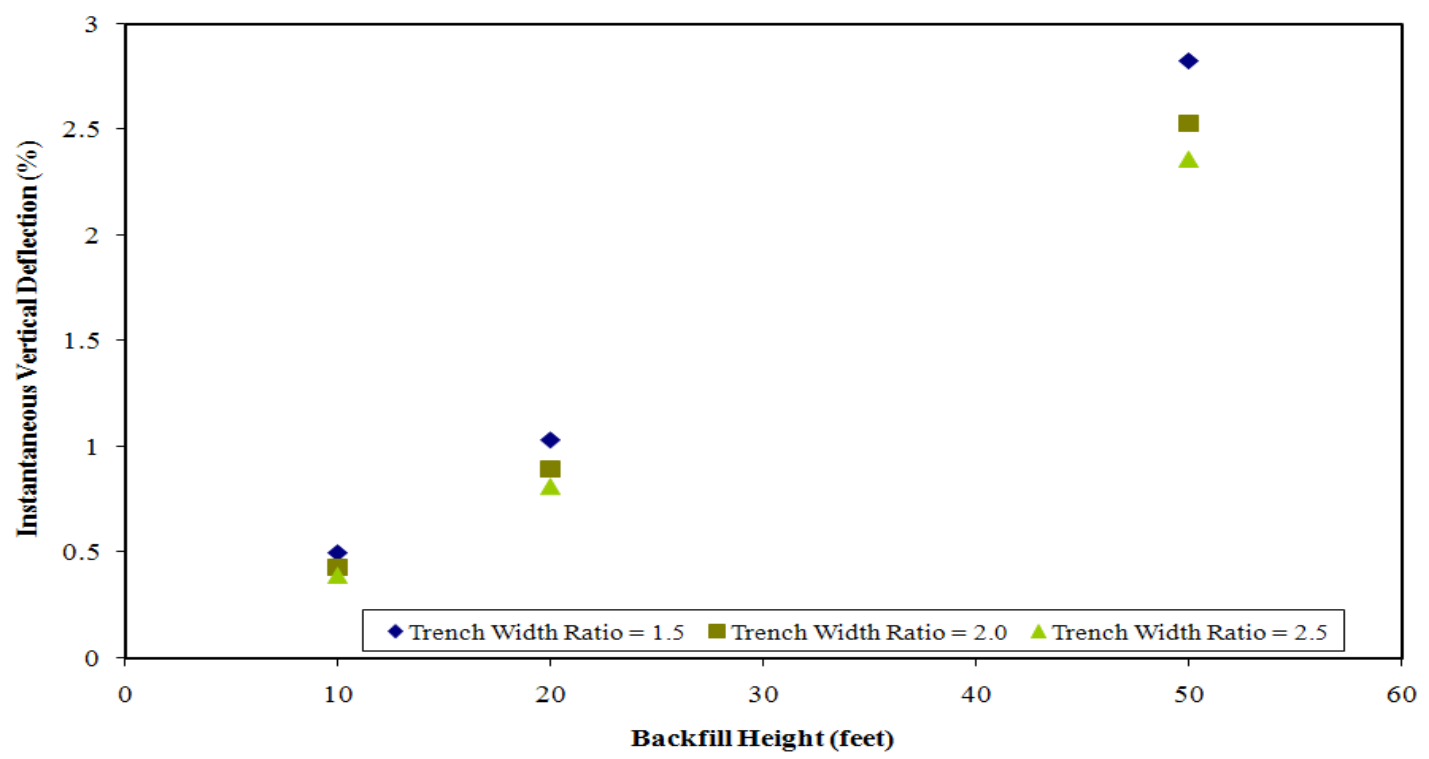

Figure 7.54: Effect of trench width on the vertical deflection of a 120 inch $(3 \mathrm{~m})$ corrugated steel pipe installed in granular stone.

The instantaneous deformations of pipes with various diameters installed under different fill heights and CLSM are shown in Figure 7.55. The instantaneous deformations of pipes with various diameters installed under different fill heights and 
granular stone are shown in Figure 7.56. The trench width in these cases is equal to two times the mean diameter of the pipe. Results show that the deformation trend is similar for all the pipe diameters. The vertical deformations were higher when granular stone was used as backfill, which is similar to what was presented earlier.

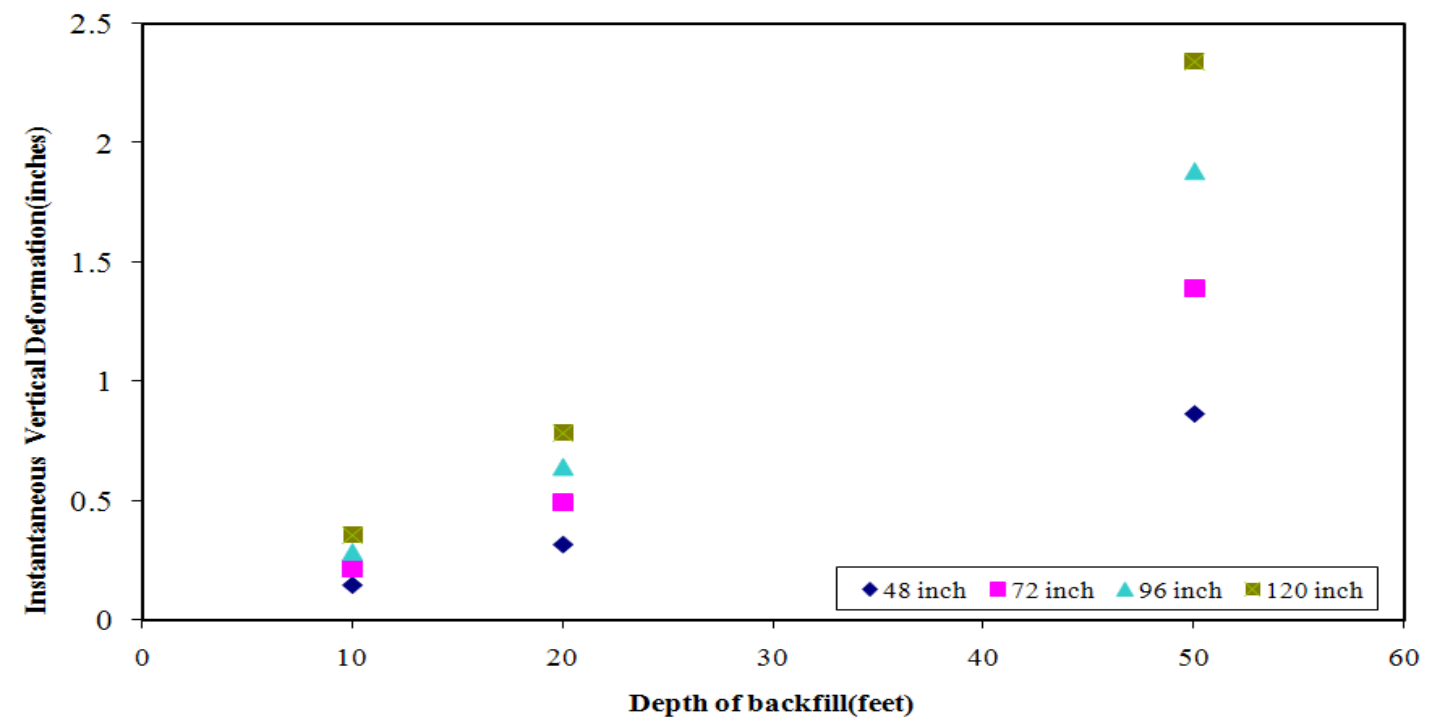

Figure 7.55: Instantaneous vertical deformation of various corrugated steel pipe diameters installed in CLSM .

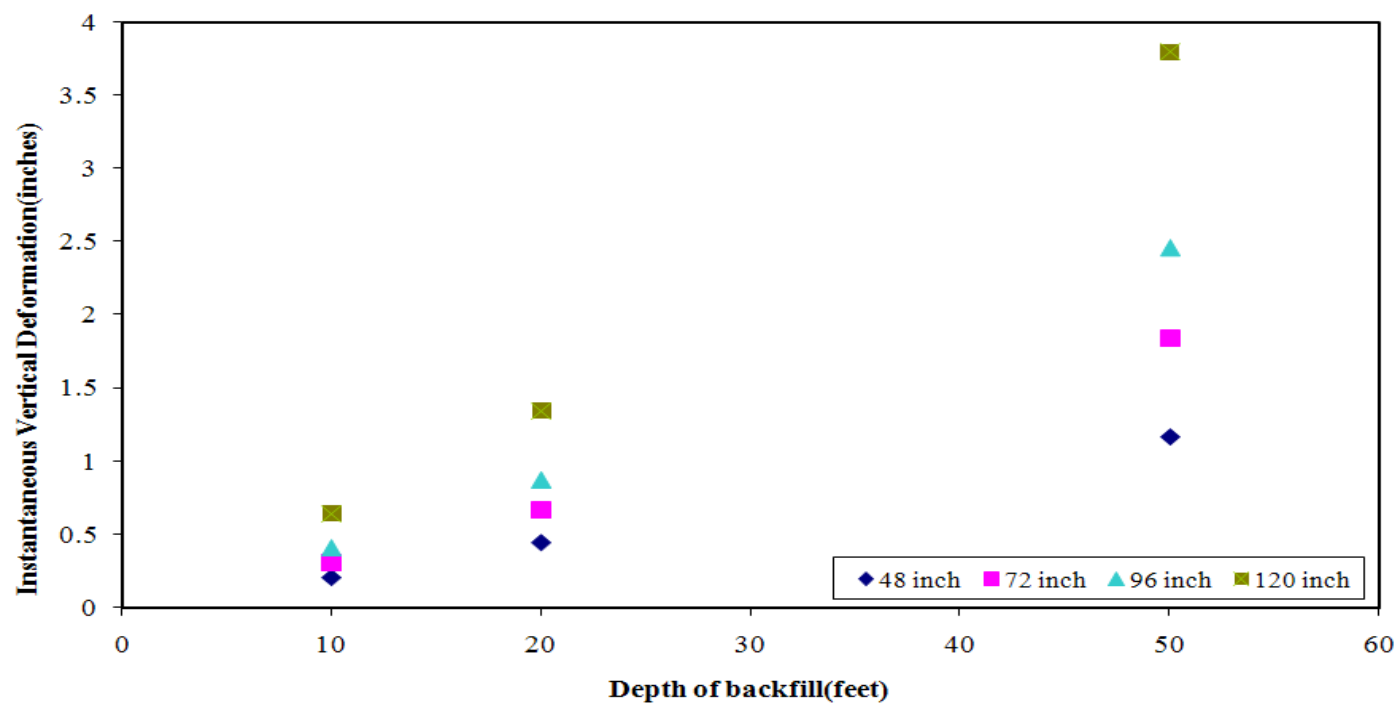

Figure 7.56:Instantaneous vertical deformation of various corrugated steel pipe diameters installed in granular stone. 


\subsubsection{Response due to HS $\mathbf{- 2 5}$ truck loading + self-weight of the soil}

Figure 7.57 shows the instantaneous pipe deformation contours of a 120 inch (3 m) corrugated steel pipe installed at a depth of 20 feet $(6 \mathrm{~m})$ in CLSM. The loads considered are the HS-25 truck loads and self-weight of the soil. Figure 7.58 shows the vertical pipe deflections of a 120 inch (3 m) corrugated steel pipe installed in CLSM and granular stone at a depth of 50 feet $(15 \mathrm{~m})$. The trench width is equal to two times the mean diameter of the pipe. The pipe deflections were computed by taking the difference between the magnitudes of vertical displacement at the crown and base of the pipe.

Figure 7.58 shows a comparison of pipe deflections under different pipe backfill materials. The magnitude of vertical pipe deflection is higher when granular stone is used as pipe backfill. Figure 7.59 and Figure 7.60 show the percentage vertical deflection of a 120 inch (3 m) corrugated steel pipe installed in CLSM and granular stone, respectively. The vertical pipe deflections increased with an increase in backfill heights. Figures 7.61 and 7.62 show the influence of trench width on the vertical deflections of a pipe installed in CLSM and granular stone, respectively. It can be observed that the pipe deflections decreased with an increase in trench widths. Also, Figures 7.61 and 7.62 illustrates that a 120 inch (3 m) corrugated steel pipe can be installed up to a depth of 50 feet $(15 \mathrm{~m})$ with the trench width ratio as small as 1.5 without causing a pipe failure. 

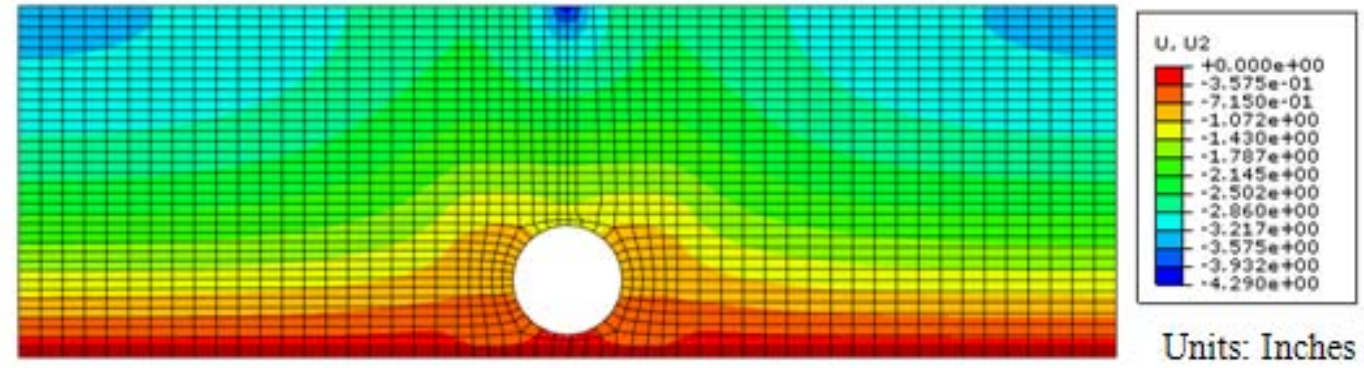

Units: Inches

Figure 7.57: Instantaneous deformation in the soil-pipe system under HS-25 truck loading.

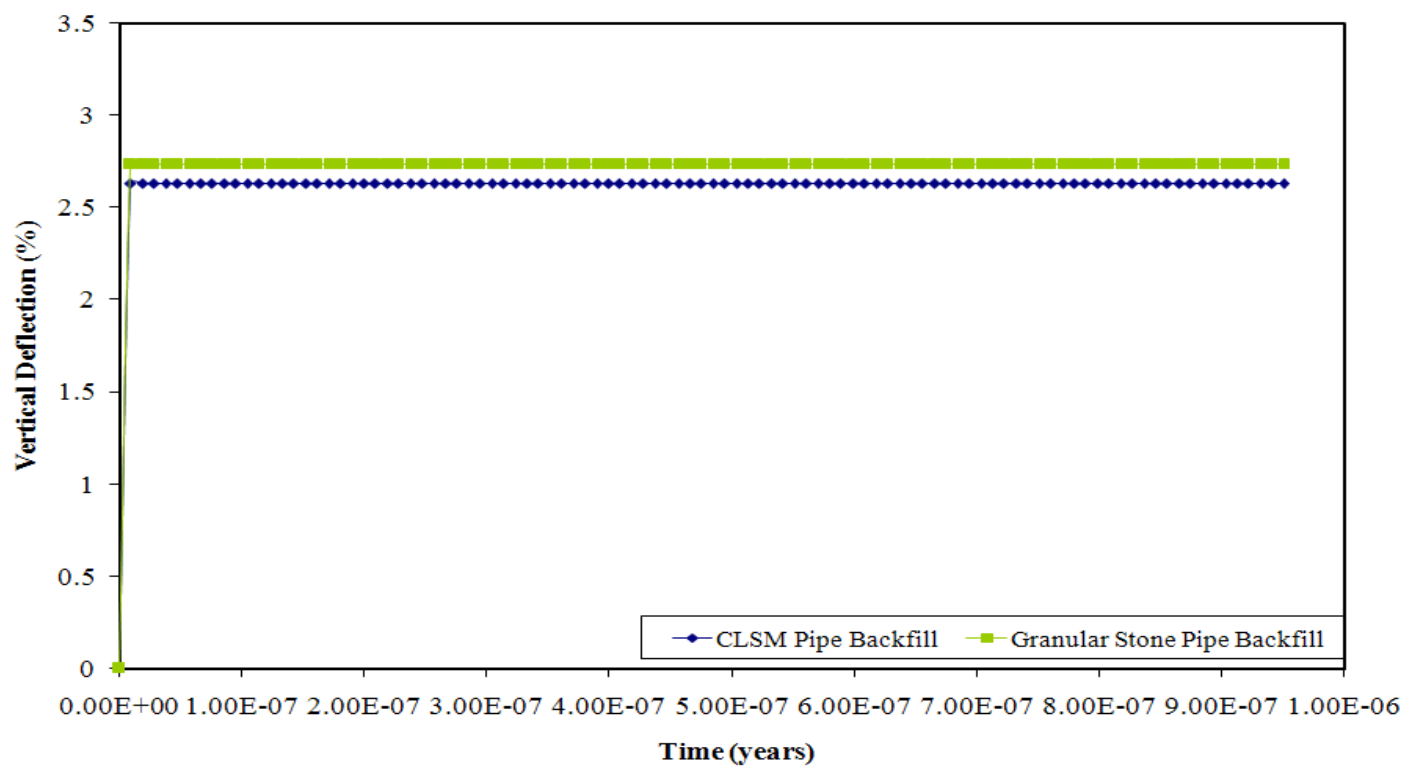

Figure 7.58: Instantaneous vertical pipe deflection of a 120 inch $(3 \mathrm{~m})$ corrugated steel pipe installed at a depth of 50 feet $(15 \mathrm{~m})$ under HS-25 loads and self-weight of soil . 


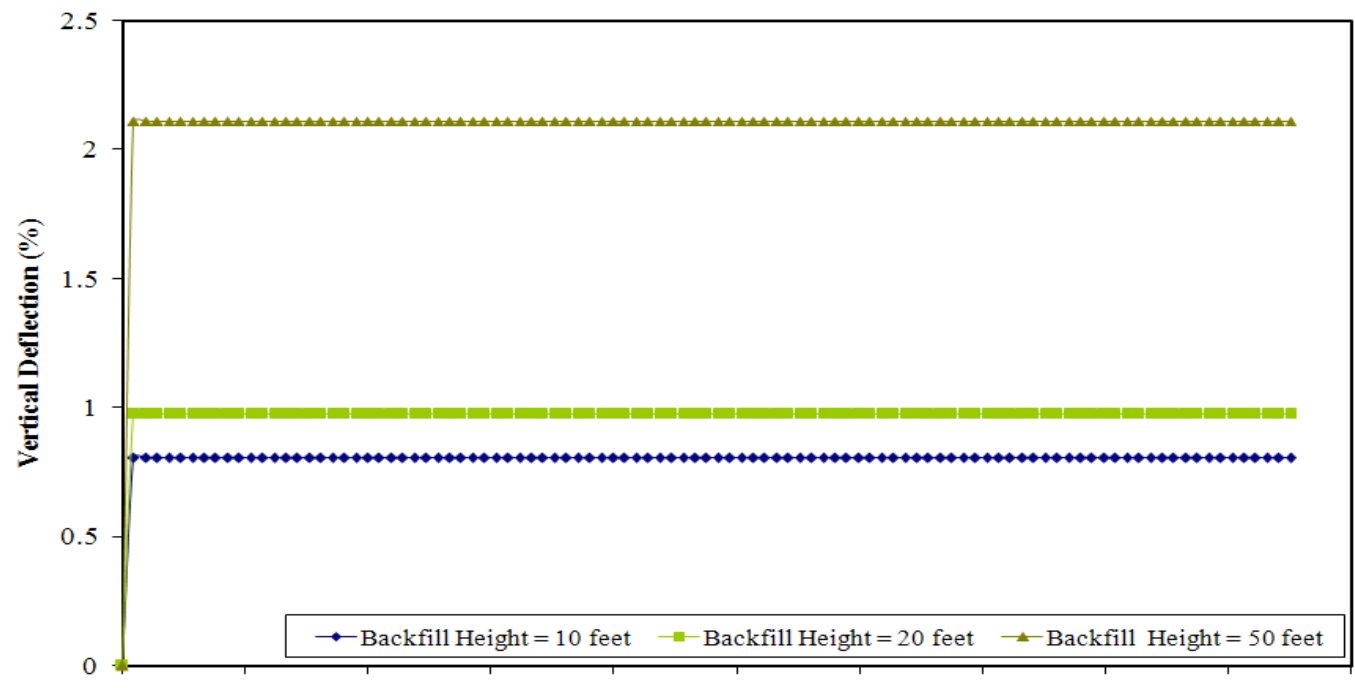

0.00E+00 1.00E-07 2.00E-07 3.00E-07 4.00E-07 5.00E-07 6.00E-07 7.00E-07 8.00E-07 9.00E-07 1.00E-06

Time (years)

Figure 7.59: Vertical deflections of a 120 inch $(3 \mathrm{~m})$ corrugated steel pipe installed in CLSM under HS-25 loads and self-weight of soil.

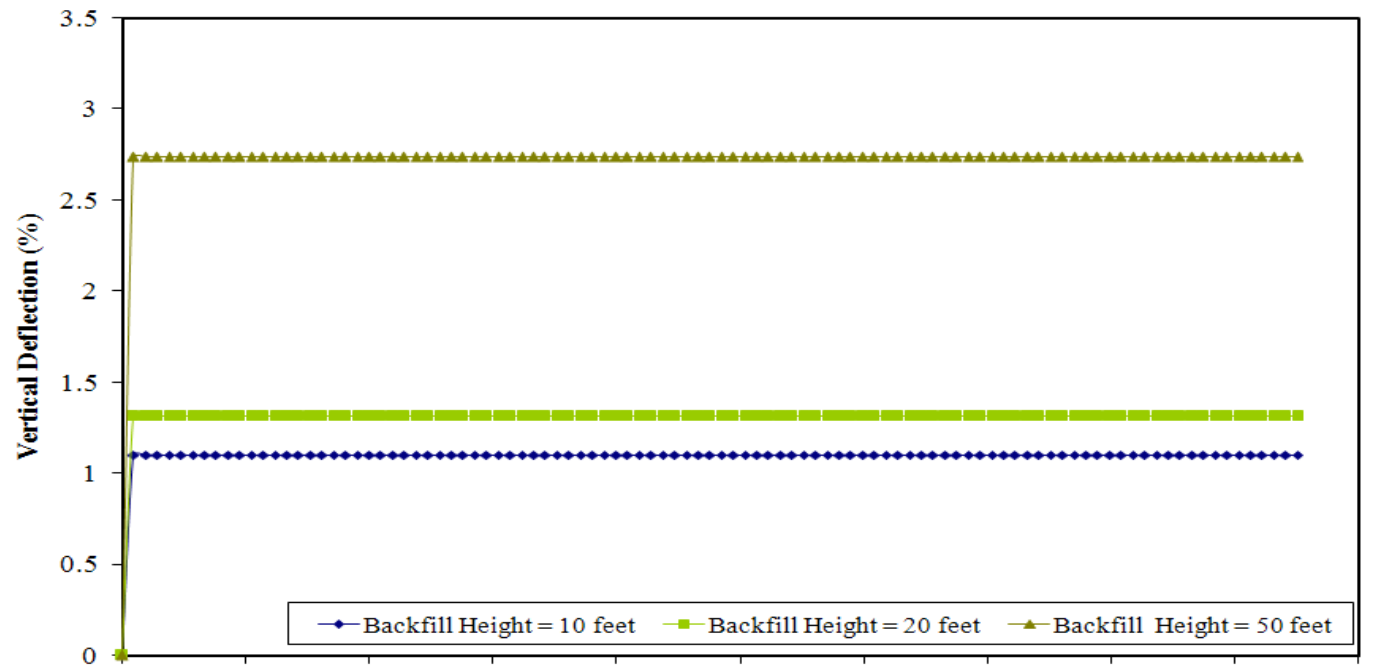

0.00E+00 1.00E-07 2.00E-07 3.00E-07 4.00E-07 5.00E-07 6.00E-07 7.00E-07 8.00E-07 9.00E-07 1.00E-06

Time (years)

7.60: Vertical deflections due of a 120 inch $(3 \mathrm{~m})$ corrugated steel pipe installed in granular stone under HS-25 load and self-weight of soil. 


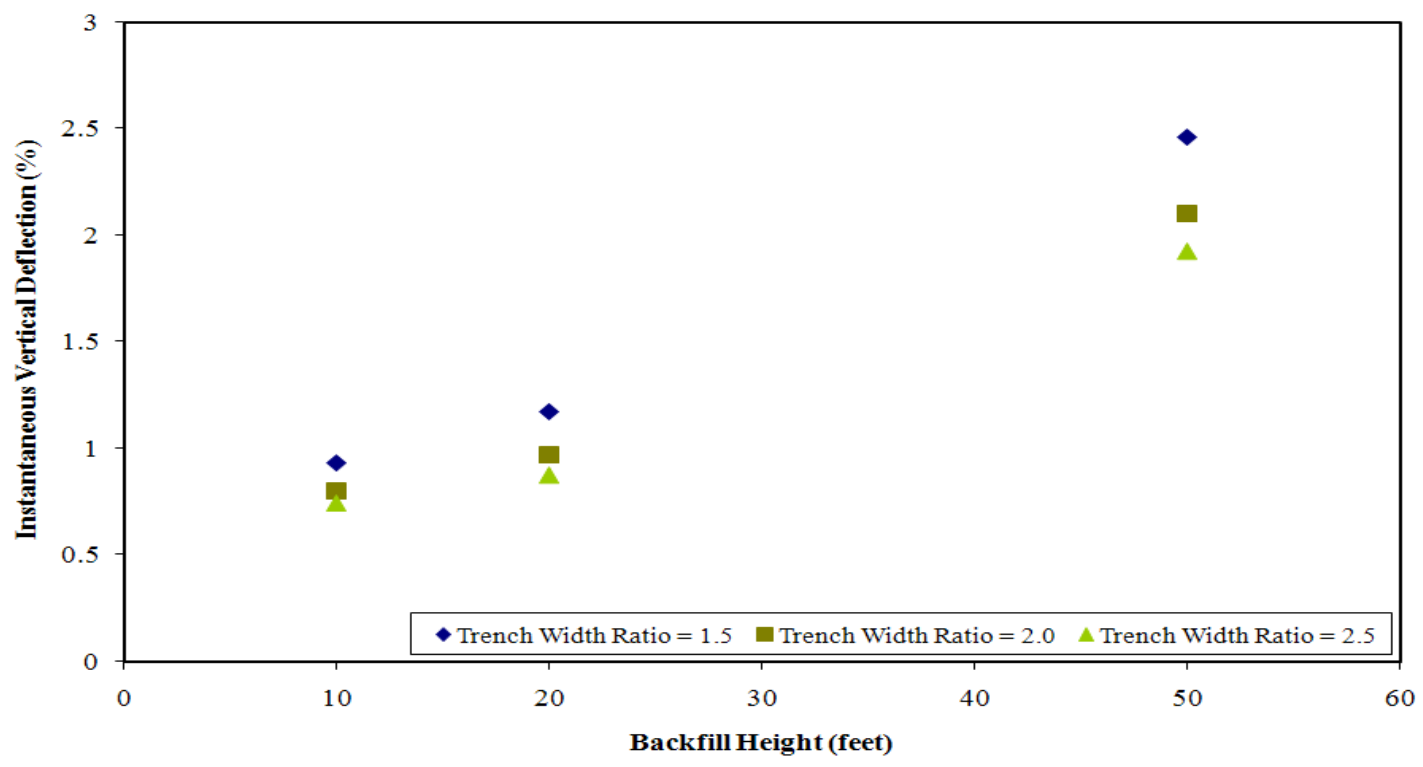

Figure 7.61: Effect of trench width ratio on the vertical deflections of a 120 inch $(3 \mathrm{~m})$ corrugated steel pipe installed in CLSM under HS-25 load and self-weight of soil.

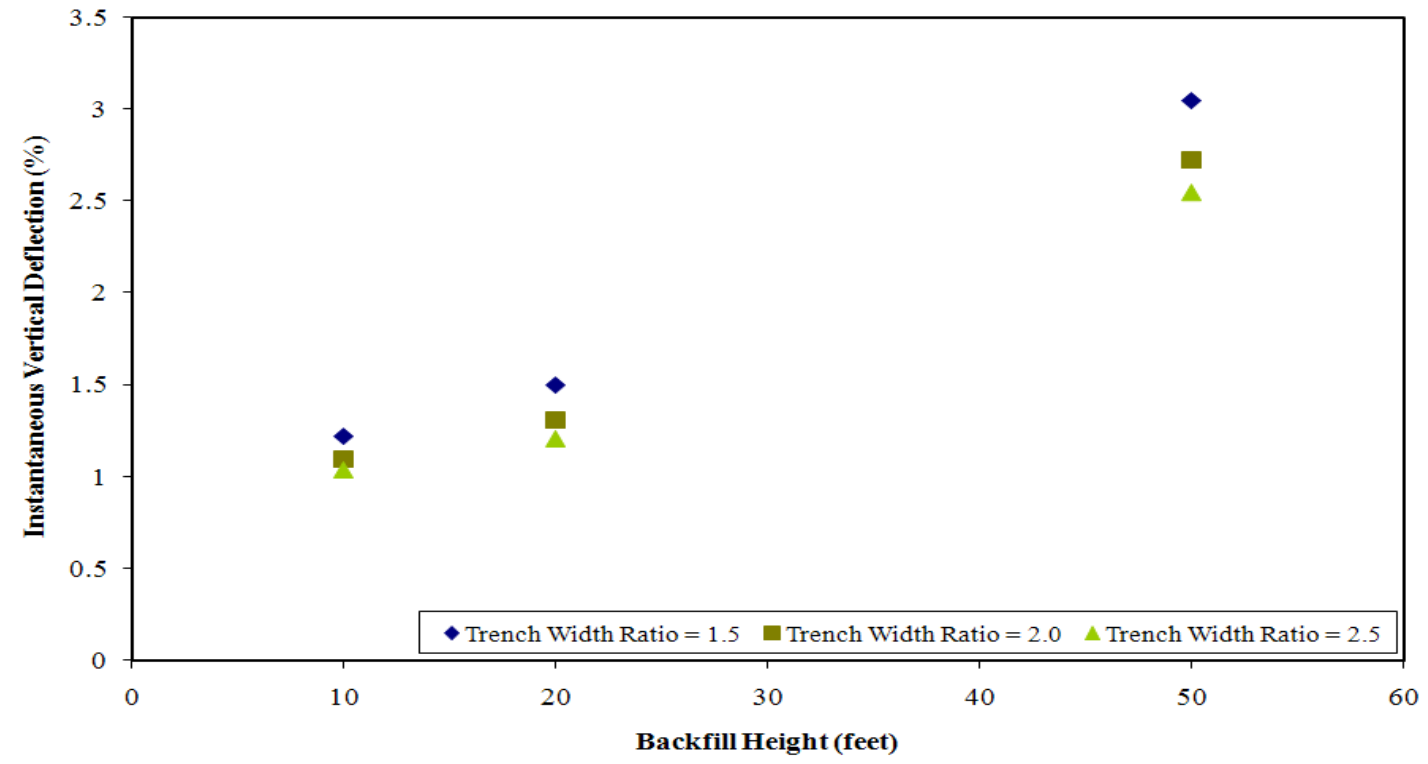

Figure 7.62:Effect of trench width ratio on the vertical deflections of a 120 inch $(3 \mathrm{~m})$ corrugated steel pipe installed in granular stone under HS-25 load and self-weight of soil. 
The instantaneous deformation of pipes with various diameters installed under different fill heights and CLSM are shown in Figure 7.63. The instantaneous deformation of pipes with various diameters installed under different fill heights and granular stone are shown in Figure 7.64. The trench width in these cases is equal to two times the mean diameter of the pipe. Results show that the deformation trend is similar for all the pipe diameters. The vertical deformations were higher when granular stone was used as backfill, which is similar to what was presented earlier. Tables 7.9 and 7.10 present the comparison between the pipe deflections due to self-weight of soil and self-weight of soil plus HS-25 loads under CLSM and granular stone backfill, respectively.

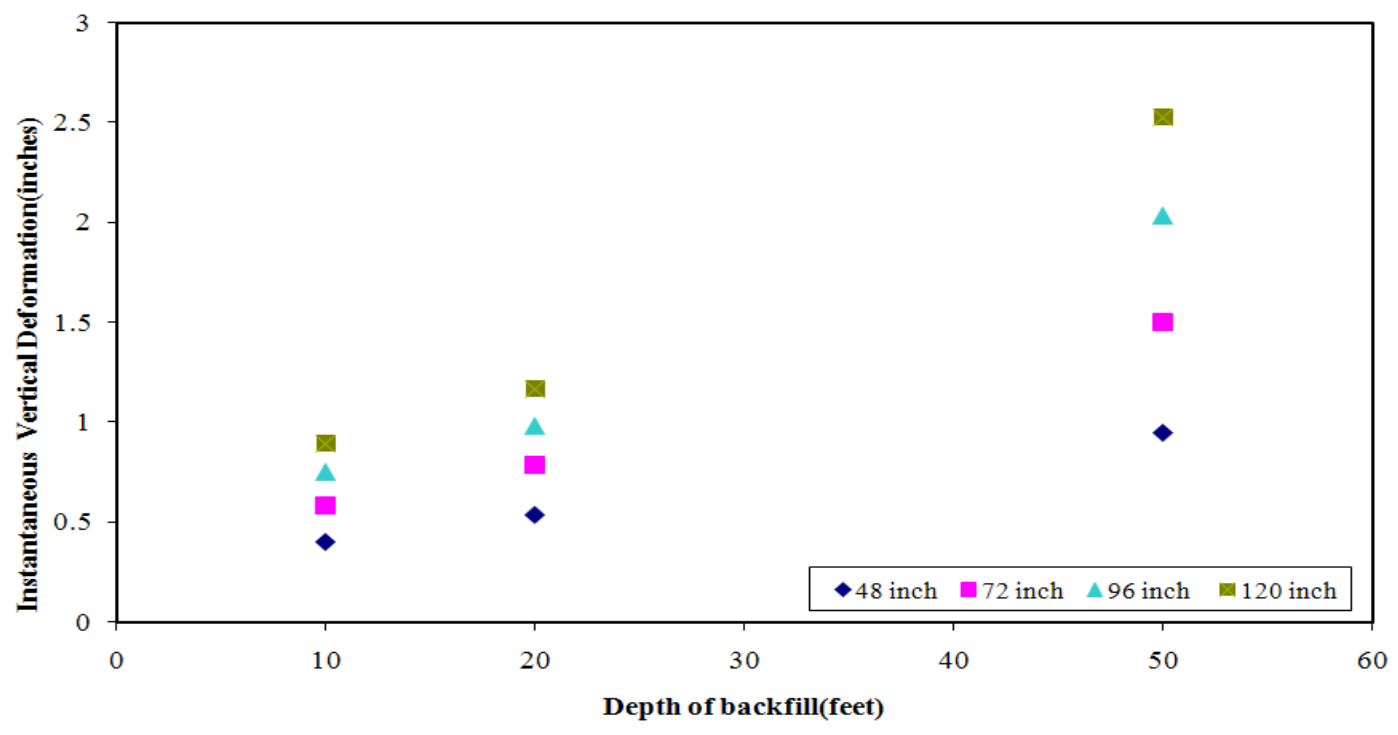

Figure 7.63: Instantaneous vertical deformation of various corrugated steel pipe diameters installed in CLSM under HS-25 load and self-weight of soil. 


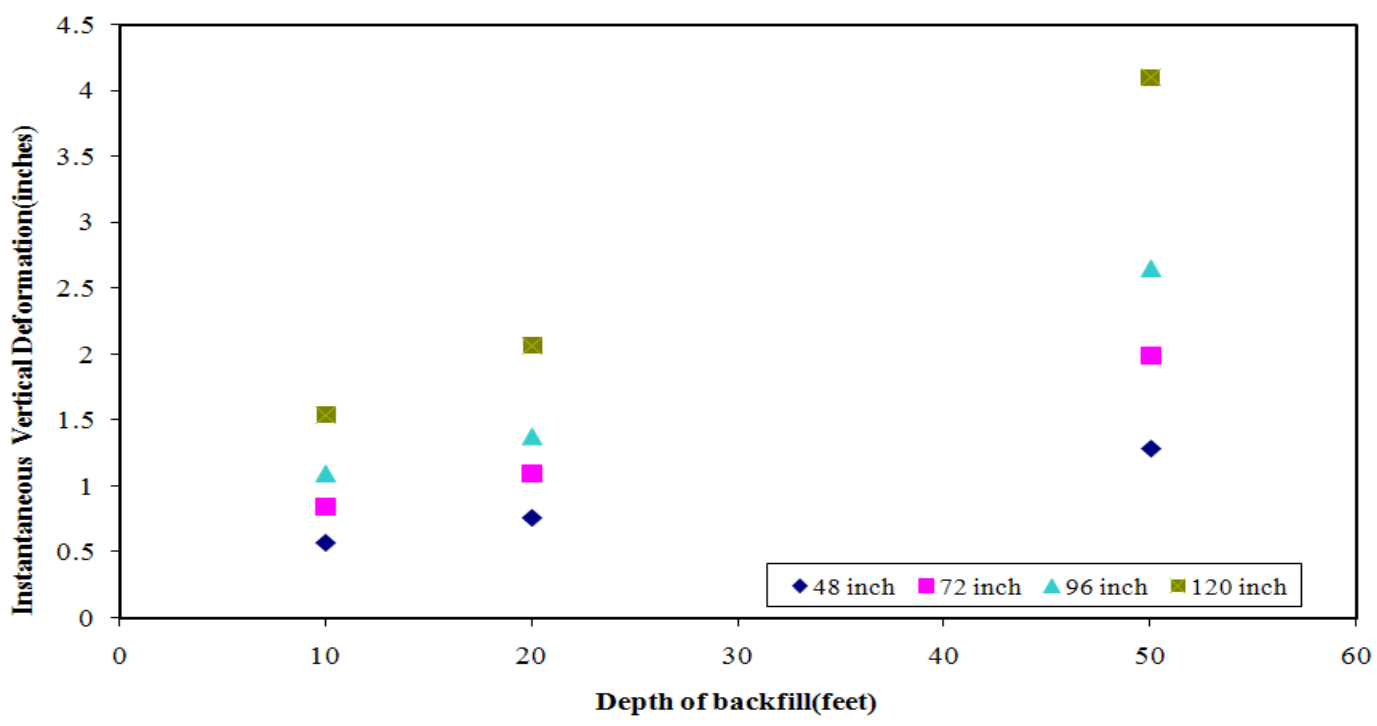

Figure 7.64: Instantaneous vertical deformation of various corrugated steel pipe diameters installed in granular stone under HS-25 load and self-weight of soil. 
Table 7.9: Instantaneous Vertical Pipe Deflection of Corrugated Steel Pipes Installed in CLSM

\begin{tabular}{|c|c|c|c|c|}
\hline \multirow[b]{2}{*}{$\begin{array}{l}\text { Pipe Diameter } \\
\text { inches (m) }\end{array}$} & \multirow[b]{2}{*}{$\begin{array}{c}\text { Backfill } \\
\text { Depth } \\
\text { feet }(m)\end{array}$} & \multicolumn{2}{|c|}{ Vertical Deflection (inches) } & \multirow[b]{2}{*}{$\begin{array}{l}\text { Percentage increases in } \\
\text { deflection }(\%) \\
\left(\frac{\left(\mathrm{V}_{\mathrm{dl}+\mathrm{II}-} \mathrm{V}_{\mathrm{dl}}\right)}{\mathrm{V}_{\mathrm{dl}}}\right) * 100\end{array}$} \\
\hline & & $\begin{array}{l}\text { Self-weight } \\
\text { of soil }\left(V_{d l}\right)\end{array}$ & $\begin{array}{c}\text { Self-weight } \\
\text { of soil }+ \\
\text { HS-25 load } \\
\left(V_{d 1+11}\right)\end{array}$ & \\
\hline \multirow{3}{*}{$48(1.20)$} & $10(3)$ & 0.145 & 0.406 & 180 \\
\hline & $20(6)$ & 0.3157 & 0.5419 & 72 \\
\hline & 50 (15) & 0.8651 & 0.9519 & 10 \\
\hline \multirow{3}{*}{$72(1.80)$} & $10(3)$ & 0.2164 & 0.5884 & 172 \\
\hline & $20(6)$ & 0.4945 & 0.7921 & 60 \\
\hline & $50(15)$ & 1.3926 & 1.5054 & 8 \\
\hline \multirow{3}{*}{$96(2.40)$} & $10(3)$ & 0.2883 & 0.75 & 160 \\
\hline & $20(6)$ & 0.6447 & 0.9801 & 52 \\
\hline & $50(15)$ & 1.88244 & 2.0341 & 8 \\
\hline \multirow{3}{*}{$120(3.00)$} & $10(3)$ & 0.358 & 0.8959 & 150 \\
\hline & $20(6)$ & 0.7876 & 1.17 & 49 \\
\hline & $50(15)$ & 2.3415 & 2.5269 & 8 \\
\hline
\end{tabular}


Table 7.10: Instantaneous Vertical Pipe Deflection of Corrugated Steel Pipes Installed in Granular Stone

\begin{tabular}{|c|c|c|c|c|}
\hline \multirow[b]{2}{*}{$\begin{array}{l}\text { Pipe Diameter } \\
\text { inches (m) }\end{array}$} & \multirow[b]{2}{*}{$\begin{array}{c}\text { Backfill } \\
\text { Depth } \\
\text { feet (m) }\end{array}$} & \multicolumn{2}{|c|}{ Vertical Deflection (inches) } & \multirow[b]{2}{*}{$\begin{array}{l}\text { Percentage increases in } \\
\text { deflection }(\%) \\
\left(\frac{\left(\mathrm{V}_{\mathrm{dl}+\mathrm{Il}-} \mathrm{V}_{\mathrm{dl}}\right)}{\mathrm{V}_{\mathrm{dl}}}\right) * 100\end{array}$} \\
\hline & & $\begin{array}{l}\text { Self-weight } \\
\text { of soil }\left(V_{\mathrm{dl}}\right)\end{array}$ & $\begin{array}{c}\text { Self-weight of } \\
\text { soil + HS-25 } \\
\text { load }\left(V_{d++l l}\right)\end{array}$ & \\
\hline \multirow{3}{*}{$48(1.20)$} & $10(3)$ & 0.2045 & 0.576 & 182 \\
\hline & $20(6)$ & 0.4436 & 0.7644 & 72 \\
\hline & 50 (15) & 1.1672 & 1.2853 & 10 \\
\hline \multirow{3}{*}{$72(1.80)$} & $10(3)$ & 0.3114 & 0.849 & 173 \\
\hline & $20(6)$ & 0.6724 & 1.1035 & 64 \\
\hline & 50 (15) & 1.8451 & 1.9955 & 8 \\
\hline \multirow{3}{*}{$96(2.40)$} & $10(3)$ & 0.4149 & 1.0966 & 164 \\
\hline & $20(6)$ & 0.8776 & 1.379 & 57 \\
\hline & $50(15)$ & 2.4622 & 2.6564 & 8 \\
\hline \multirow{3}{*}{$120(3.00)$} & $10(3)$ & 0.6448 & 1.542 & 139 \\
\hline & $20(6)$ & 1.3437 & 2.07016 & 54 \\
\hline & 50 (15) & 3.7974 & 4.1051 & 8 \\
\hline
\end{tabular}

From Tables 7.9 and 7.10, the variation in deflection percentages indicates that the effect of live loads decreases with increase in depth. At depths greater than 20 feet (6 $\mathrm{m})$ the change in vertical deflection is not so significant. 


\section{Chapter 8: SUMMARY AND CONCLUSION}

\subsection{Summary}

In this study, the performance of buried pipes under different backfill materials, trench widths, fill heights, and different pipe materials (HDPE, PVC, Concrete, and Steel) was investigated. In order to understand the time dependent behavior of pipe materials like high density polyethylene (HDPE), polyvinyl chloride (PVC), and concrete, a critical literature review was performed. Creep analyses for a time period of 50 years were performed for high density polyethylene, polyvinyl chloride, and reinforced concrete pipes. Creep models reported by Hashash (1991), Janson (1995), and Bazant \& Osman (1976) were chosen for high density polyethylene (HDPE), polyvinyl chloride (PVC) and concrete, respectively. Steel pipes do not show creep behavior under operational conditions (temperature and pressure) in highway applications. Therefore, only static analyses were performed for buried steel pipes. Two pipe backfill materials were considered in this study- controlled low strength material (CLSM) and granular stone (also known as crushed stone). Soil properties were obtained from the data available in the literature as described in Chapter 3 of this report. In this study, pipe diameters ranging from 18 inch $(0.45 \mathrm{~m})$ to 120 inch $(3 \mathrm{~m})$ were selected. The performance of a buried pipe installed in a trench with a width varying between $1.5 \mathrm{D}$ to 2.5D ( $\mathrm{D}$ is the mean diameter of the pipe) was investigated. Fill heights of 10 feet $(3 \mathrm{~m})$, 20 feet $(6 \mathrm{~m})$, and 50 feet $(15 \mathrm{~m})$ were investigated. Two loading conditions were used in the study: self-weight of the soil (dead load) and HS-25 truck load (live load) along with the self-weight of the soil. Results from the analyses were presented and discussed in Chapter 7 of this report. 


\subsection{Conclusions}

Following conclusions were drawn based on the results presented in this research work:

- The elastic modulus of pipe backfill has significant effect on the pipe deformation. Greater the elastic modulus of confinement material (pipe backfill) lesser is the deformation.

- For HDPE and PVC pipes, the fifty year pipe deformations obtained from the comprehensive creep analyses compared well with the deformations obtained from the AASHTO (2007) method. As described in Chapter 7, the AASHTO method recommends a static analysis by using a reduced elastic modulus.

- Pipe deformations increased with an increase in burial depth and a decrease of trench width (i.e., trench width ratio defined in Chapter 7).

- For all the pipes, $60 \%$ to $80 \%$ of pipe deflections occur during the first year of installation. The pipe materials and the loading conditions have an influence on the percentage deflections during the first year of installations. For example, the deflection percentage during the first year of installations for a PVC pipe was about $70 \%$ of the total deflection. For HDPE pipes, this percentage was in the range of $60 \%-80 \%$.

- Under similar boundary and loading conditions, HDPE pipes deflected more than PVC pipes.

- With an increase in backfill depth, the influence of HS-25 loads on the pipe deformations decreased.

- For a reinforced concrete pipe, the choice of pipe backfill materials and trench widths had an insignificant influence on the pipe deformation. 
- For PVC pipes, fill heights could be as high as 50 feet $(15 \mathrm{~m})$ for a trench width ratio of 1.5. However, HDPE pipes exhibit the possibility of failure at 50 feet (15 m) burial depth under the combination of live and dead loads. Computed deflections in concrete and steel pipes are small and hence could be installed up to depths of 50 feet $(15 \mathrm{~m})$.

- The consideration of the creep behavior of the pipe materials in the analysis is necessary for forecasting stresses, strains, and failure loading (buried depth) over an extended period of time (50 years).

\subsection{Recommendations}

- Trench width ratio greater than 1.5 can be used in pipe installations.

- Granular stone can be used as pipe backfill instead of CLSM for all the pipes without causing a failure under assumed conditions.

- PVC, reinforced concrete, and corrugated steel can be installed up to a depth of 50 feet.

\subsection{Future work}

- Perform finite element analyses to study the effect of HS-25 truck loads on pipes installed at shallow depths.

- Perform finite element analyses to determine failure depth of HDPE pipes. 


\section{'REFERENCES}

AASHTO (2007) American Association of State Highway and Transportation Officials (AASHTO) LFRD Bridge Design Specifications, Customary U.S. Units, $4^{\text {th }}$ Edition, Washington D.C.

AASHTO M 294 (2007) Standard Specification for Corrugated Polyethylene Pipe, 300- to 1500-mm Diameter. American Association of State Highway and Transportation Officials.

AASHTO T 99 (2009) Standard Method of Test for Moisture-Density Relations of Soils Using a 2.5-kg (5.5-lb) Rammer and a 305-mm (12-in.) Drop. American Association of State Highway and Transportation Officials.

ABAQUS version 6.7 (2007) ABAQUS User’s Manual. Simulia., Providence, RI.

ACPA, American Concrete Pipe Association: Highway Live Loads on Concrete Pipe [Online]. (2009) Available: www.concrete-pipe.org

ACPA, American Concrete Pipe Association: Three-Edge Bearing Strengths NonReinforced Concrete Pipe and Clay Pipe [Online]. (1974) Available: www.concretepipe.org

ADS, Inc., Advanced Drainage Systems: Technical notes [Online]. (1994) Available: http://www.ads-pipe.com

ADS, Inc., Advanced Drainage Systems: Technical notes [Online]. (2009) Available: http://www.ads-pipe.com

ADS, Inc., Advanced Drainage Systems: Technical notes [Online]. (2006) Available: http://www.ads-pipe.com

Amarasiri, A.L., (2000) Evaluation of Granular Backfill Materials for Large-Diameter High Density Polyethylene Pipe, M.S Thesis, Department of Civil Engineering, Texas Tech University.

Arockiasamy, M., Chaallal,O., and Limpeteeprakar,T. (2006) Full-Scale Field Tests on Flexible Pipes under Live Load Application. Journal of Performance of Constructed Facilities, Vol. 20, No. 1, pp. 21-27

Arvidsson, J. and Gronavall, J. (2004) Analysis of Creep in Paperboard Packages with Plastic Tops. M.S. Thesis, Division of Structural Mechanics, LTH, Lund University, Sweden. 
Ashby, M., Shercliff, H., Cebon, D. (2009) Materials: Engineering, Science, Processing and Design, Butterworth- Heinemann, Oxford, UK.

ASTM C 76 (2010) Standard Specification for Reinforced Concrete Culvert, Storm Drain, and Sewer Pipe. American Standard for Testing Materials.

ASTM C 1479 (2007) Standard Practice for Installation of Precast Concrete Sewer, Storm Drain, and Culvert Pipe Using Standard Installations. American Standard for Testing Materials.

ASTM D 2321 (2000) Standard Practices for Underground Installation of Thermoplastic Pipe for Sewers and other Gravity-Flow Applications. American Standard for Testing Materials.

ASTM D2412 (2000) Standard Test Method for Determination of External Loading Characteristics of Plastic Pipe by Parallel-Plate Loading. American Standard for Testing Materials.

ASTM D 2487 (2000) Standard Classification of Soils for Engineering Purposes (Unified Soil Classification System). American Standard for Testing Materials.

ASTM D1784 (2007) Standard Specification for Rigid Poly (Vinyl Chloride) (PVC) Compounds and Chlorinated Poly (Vinyl Chloride) (CPVC) Compounds. American Standard for Testing Materials.

ASTM D256 (2006) Standard Test Methods for Determining the Izod Pendulum Impact Resistance of Plastics. American Standard for Testing Materials.

ASTM D3034 (2006) Standard Specification for Type PSM Poly (Vinyl Chloride) (PVC) Sewer Pipe and Fittings. American Standard for Testing Materials.

ASTM D638 (2008) Standard Test Method for Tensile Properties of Plastics. American Standard for Testing Materials.

ASTM D792 (2000) Standard Test Methods for Density and Specific Gravity (Relative Density) of Plastics by Displacement. American Standard for Testing Materials.

ASTM F1803 (2004) Standard Specification for Poly (Vinyl Chloride)(PVC) Closed Profile Gravity Pipe and Fittings Based on Controlled Inside Diameter. American Standard for Testing Materials.

ASTM F679 (2006) Standard Specification for Poly (Vinyl Chloride) (PVC) LargeDiameter Plastic Gravity Sewer Pipe and Fittings. American Standard for Testing Materials. 
ASTM F794 (2009) Standard Specification for Poly (Vinyl Chloride) (PVC) Profile Gravity Sewer Pipe and Fittings Based on Controlled Inside Diameter. American Standard for Testing Materials.

ASTM F949 (2009) Standard Specification for Poly (Vinyl Chloride) (PVC) Corrugated Sewer Pipe with a Smooth Interior and Fittings. American Standard for Testing Materials.

Bazant, Z. P., and Chern, J. C . (1984) Log-Double Power Law for Concrete Creep, Report No. 83-1l/679e, Center for Concrete and Geomaterials, The Technological Institute, Northwestern University, Evanston, 111., 1983; American Concrete Institute Journal, Vol. 81.

Bazant, Z.P., and Chern, J.C. (1985) Triple Power law for Concrete Creep, Journal of Engineering Mechanics, Vol.111, No. 1, pp. 64-83.

Bazant, Z.P., and Osman, E. (1976) Double Power Law for Basic Creep of Concrete, Journal of Materials and Structures, Vol. 9, pp. 3-11.

Brachman, R.W.I., Moore, I.D., and Rowe, R.K. (1996) Interpretation of Buried Pipe Test: Small Diameter Pipe in Ohio University facility. Transportation Research Record 1541, Structures, Culverts, and Tunnels, pp. 64-75.

Brachman, R.W.I., Moore, I.D., and Rowe, R.K. (2000) The Design of a Laboratory Facility for Evaluating the Structural Response of Small-Diameter Buried Pipe. Canadian Geotechnical Journal, Vol. 37, pp. 281-295.

Brewer, W.E. (1990) The Design and Construction of Culverts using Controlled Low Strength Material - Controlled Density Fill (CLSM-CDF) Backfill. Structural Performance of Flexible Pipes, Proceedings of the First National Conference on Flexible Pipes, Sargand, S.M., Mitchell, G.F., \& Hurd, J.O. (eds), October 21-23, Columbus, Ohio, pp. 109 -118.

Brewer, W.E., and Hurd, J.O. (1993) Controlled Low Strength Material - Controlled Density Fill (CLSM-CDF) as a Backfill around Flexible Structures. Structural Performance of Pipes, Proceedings of the Second Conference on Structural Performance of Pipes, Sargand, G.F., Mitchell, G.F., \& Hurd, J.O (eds), March 14-17, Columbus, Ohio, pp.25-34.

Buczala, G. S., and M. J. Cassady, eds., Buried Plastic Pipe Technology, ASTM STP 1093, American Society for Testing and Materials, 1990.

Bulson, P.S. (1990) Buried structures: Static and Dynamic Strength. Chapman \& Hall, New York. 
Burns, J.Q., and Richard, R.M. (1964) Attenuation of Stresses for Buried Cylinders. Proceedings of the Symposium on Soil-Structure Interaction, University of Arizona, Tucson.

Chamber R.F., McGrath, T.J., and Heger, F.J. (1980) Plastic Pipe for Subsurface Drainage for Drainage of Transportation Facilities. NCHRP Report 225, Transportation Research Board, Washington, D.C., October, pp. 122-140.

Chehab, A and Moore, I. D. (2004) A Uniaxial Linear Viscoelastic-Viscoplastic Model for High Density Polyethylene. Proceedings of the 57th Canadian Geotechnical Conference, 5th Joint CGS/IAH-CNC Conference, Quebec, October, pp. 6D1-6D6

Cho, S. and Vipulanandan, C. (2005) Flowable Backfill with Flexible Pipe in Trench Condition and FEM Verification. Proceedings of the Pipeline Division Specialty Conference, Houston, Texas, August 21-24, pp 1079-1088.

Chua, K.M. (1986) Time-Dependent Interaction of Soil and Flexible pipe. Texas A \& M University.

Chua, K. M. and Lytton, R. L. (1987) A New Method of Time-Dependent Analysis for Interaction of Soil and Large-Diameter Flexible Pipe. 66th Annual Meeting of the Transportation Research Record, Washington D.C.

Contech Construction Products, [Online].2010 Available: http://contech-cpi.com/

Cook, R.D., Malkus, D.S., Plesha, M.E., and Witt, R.J. (2003) Concepts and applications of finite element analysis. John Wiley \& Sons, Inc., Indianapolis, Indiana.

Desai, C.S. and Abel, J.F. (1972) Introduction to the Finite Element Method - A numerical method for Engineering Analysis, East-West Edition, East-West Press Private Limited, New Delhi/Madras, India.

Corrugated Steel Pipe Design Manual (2008). National Corrugated Steel Pipe Association (NCSPA).

Crosby, M.K. (2003) Finite Element Analysis of a Laboratory Soil Box Test Facility for Evaluation the Structural Response of Concrete Pipe. M.S.Thesis, University of Florida.

Dhar, A.S. and Moore, I.D. (2002) Corrugated High Density Polyethylene Pipe: Laboratory Evaluation of Two-Dimensional Analyses for Limit States Design. Transportation Research Record, No. 1814, pp. 157-163.

Diamond Plastics Corporation, Specification Data [Online]. (2005) Available:http://www.dpcpipe.com/, [2005]. 
Fanourakis, G.C. and Ballim, Y. (2003) Predicting Creep Deformation of Concrete: A Comparison of Results from Different Investigations. Proceedings of the 11th FIG Symposium on Deformation Measurements, Santorini, Greece, 2003.

Faragher, E., Rogers, C.D.F., and Fleming, P.R. (1998) Laboratory Determination of Soil Stiffness Data for Buried Plastic Pipes. Transportation Research Record 1624, Washington D.C., Paper No. 98-0773, pp. 231-236.

Fernando, M.E.R. (1992) Field Performance of Corrugated Plastic Pipes under Simulated High Soil Cover. M.S.Thesis, Department of Engineering, Ohio University

Gabriel, L. H., and Goddard, J. B. (1999) Curved Beam Stiffness for Thermoplastic Gravity-Flow Drainage Pipes, Transportation Research Board, pp. 51-57.

Gabriel, L.H., (1990) Keynote address: Pipe deflections - A Redeemable Asset. Structural Performance of Flexible Pipes, Proceedings of the First National Conference on Flexible Pipes, Sargand, S.M., Mitchell, G.F., \& Hurd, J.O. (eds), October 21-23, Columbus, Ohio, pp.1-6.

Gilbert, R. I., (2001) Shrinkage Cracking and Deflection - Serviceability of Concrete Structure, Electronic Journal of Structural Engineering, EJSI International, Vol. 1, pp. $2-14$.

Goddard, J.B. (2003) Structural Performance of Corrugated PE Pipe using Burns and Richards Solution, Technical Notes, Advanced Drainage Systems, October.

Gondle R. and Siriwardane, H.J. (2008) Finite Element Analysis of Long Term Performance of Buried High Density Polyethylene Culvert Pipe, The $12^{\text {th }}$ International Conference of International Association for Computer Methods and Advances in Geomechanics (IACMAG), October 1- 6, Goa, India.

Green, B.H., Staheli, K., Bennett, D., and Walley, D.M., (1998) Fly-Ash-Based Controlled Low-Strength Material (CLSM) used for Critical Micro tunneling Applications. The Design and Application of Controlled Low Strength Materials (Flowable Fill), ASTM STP 1331, Howard A.K. and Hitch J.L. (Eds.) American Society for Testing and Materials, 1998.

Hadipriono, F.C., Larew, R.E. and Lee, O.Y. (1988). Service Life Assessment of Concrete Pipe Culverts. Journal of Transportation Engineering, Vol 114, No. 2, pp. 209-220.

Hancor, Inc., (2003) Hancor Design Aids Section [Online]. Available: http://www.hancor.com 
Hanson, J.A. (1953) A Ten-year Study of Creep Properties of Concrete. Concrete Laboratory, Report Sp-38, U.S Department of the Interior, Bureau of Reclamation, Denver, Colorado.

Harboe, E.M. (1958) A Comparison of the Instantaneous and the Sustained Modulus of Elasticity of Concrete. Concrete Laboratory Report C-854, Division of Engineering. Laboratories, U.S Department of Interior, Bureau of Reclamation, Denver, Colorado.

Hartley, J.D., and Duncan, J.M. (1987) E' and its Variation with Depth. Journal of Transportation Engineering, September, Vol. 113, No. 5, Paper No. 21813.

Hashash, N. (1991) Design and Analysis of Deeply Buried Polyethylene Drainage Pipes, Ph.D.Thesis, Department of Civil Engineering, University of Massachusetts.

Hashash, N., and Selig, E.T. (1990) Analysis of the Performance of a Buried High Density Polyethylene Pipe. Structural Performance of Flexible Pipes, Proceedings of the First National Conference on Flexible Pipes, Sargand, S.M., Mitchell, G.F., \& Hurd, J.O. (eds), October 21-23, Columbus, Ohio, pp. 95-103.

Heger, F.J., (1993) New Standard Installation for Concrete Pipe-Key to Improved Design Practice. Structural Performance of Pipes, Proceedings of the Second Conference on Structural Performance of Pipes , Sargand, S.M., Mitchell, G.F., \& Hurd, J.O. (eds), March 14-17, Columbus, Ohio, pp. 7-18.

Howard A.K. and Hitch J.L. (1998) The Design and Application of Controlled Low Strength Materials (Flowable Fill), ASTM STP 1331, American Society for Testing and Materials.

Howard, A.K. (1977) Modulus of Soil Reaction Values for Buried Flexible Pipe. Journal of the Geotechnical Engineering Division, January, pp. 33-43.

Janson, L.E. (1985) Investigation of Long Term Creep Modulus of Buried Polyethylene Pipes Subjected to Constant Deflection. Advances in Underground Pipeline Engineering, pp. 253-262.

Janson, L.E. (1995) Long Term Behavior of Buried Polyvinyl Chloride Sewer Pipes. Proceedings of the $9^{\text {th }}$ International Conference on Plastic Pipes, September 18-21, Edinburgh, Scotland, UK.

Jeyapalan, J.K. (1990) Advances in Pipeline materials and Design in Europe and North America. Pipeline Design and Installation, Proceeding of International Conference on Pipeline Design and Installation, Kienow, K.K.(eds), March 25-27, Las Vegas,Neveda,pp.1-16. 
Jeyapalan, J.K., Ethiyajeevakaruna, S.W., and Boldon, B.A., (1987) Behavior and Design of Buried Very Flexible Plastic Pipes. Journal of Transportation Engineering, Vol. 113, No. 6, Paper No. 21971.

Kang, J., Parker, F. and Yoo, C.H. (2008) Soil Structure Interaction for Deeply Buried Corrugated Steel Pipes Part I: Embankment Installation. Journal of Engineering Structures, Volume 30, pp. 384-392.

Katona M.G. (1993) On the Analysis of Buried Conduits - Past, Present, and Future. Structural Performance of Pipes, Proceedings of the Second Conference on Structural Performance of Pipes , Sargand, S.M., Mitchell, G.F., \& Hurd, J.O. (eds), March 14-17, Columbus, Ohio, pp. 1-5.

Langer,W. (2006) Aggregates-Crushed Stones, Industrial Minerals \& Rocks: Commodities, Markets, and Uses. Society for Mining, Metallurgy, and Exploration, Kogel,J.K.,Trivedi,C.K.,Barker,J.M.,and Krukowski,S.T.(eds),Littleton,Colorado,USA.

L’Hermite, R.G., Mamillan, M. and Lefevre, C. (1965) Nouveaux Resultants de Recherché sur la Deformation et la rupture du Beton. Annales de l'Institut Technique du Batiment et des Travaux Publics, Vol. 18, No.207-208, pp.323-360 (see also International Conference on the Structure of Concrete, Cement and Concrete Association, London, 1968, pp.423-433).

Mada, H. (2005) Numerical Modeling of Buried Pipes with Flowable Fill as a Backfill Material. M.S.Thesis, Department of Engineering, West Virginia University.

Mallison,J.H.(1988) Corrosion-Resistant Plastic Composites in Chemical Plant Design. Marcel Dekker, Inc.,New York.

Masada, T. and Sargand, S. M. (2005) Peaking Deflections of Flexible Thermoplastic Pipe. Pipelines 2005: Optimizing Pipeline Design, Operations, and Maintenance in Today's Economy. Proceedings of the Pipeline Division Specialty Conference.

McGrath, T.J. (1993) Design of Reinforced Concrete Pipe- A Review of Traditional and Current Methods. Proceedings of the Second Conference on Structural Performance of Pipes , Sargand, S.M., Mitchell, G.F., \& Hurd, J.O. (eds), March 14-17, Columbus, Ohio, pp. 1-5.

McGrath, T.J. and Schafer, B.W. (2002) Parallel Plate Testing and Simulation of Corrugated Plastic Pipe. Transportation Research Board Annual Meeting.

McGrath, T.J., and Hoopes, R.J. (1998) Bedding Factors and E’ Values for Buried Pipe Installations Backfilled with Air-Modified CLSM. The Design and Application of 
Controlled Low Strength Materials (Flowable Fill), ASTM STP 1331, Howard A.K. and Hitch J.L. (Eds.) American Society for Testing and Materials, 1998.

Moore, I.D. (1995) Three-dimensional Response of Deeply Buried Profiled Polyethylene Pipe. Transportation Research Record, 1514, Transportation Research Board, Washington, D.C., pp. 49-58.

Moore, I.D. and Brachman, R.W.I. (1994) Three-Dimensional Analysis of Flexible Circular Culverts. Journal of Geotechnical Engineering, Vol. 120, No. 10, pp. 18291844.

Moore, I.D.(1994) Profiled HDPE Pipes Response to Parallel Plate Loading, Buried Plastic Pipe Technology, Vol 2, ASTM STP 1222,Eckstein,D, Eds., American Society for Testing and Materials, Philadelphia, pp. 25-40.

Moore, I.D., and Fuping, Hu. (1995) Response of Profiled High-Density Polyethylene Pipe in Hoop Compression. Transportation Research Record 1514, Transportation Research Board, Washington, D.C., pp. 29-36.

Moser, A.P. (2008) Buried Pipe Design. McGraw-Hill, Inc., New York.

Najafi,M., and D.T.Iseley. (1994) Evaluation of PVC Pipe for Microtunneling. Buried Plastic Pipe Technology, Eckstein, D, Ed., American Society for Testing and Materials, Philadelphia, pp. 220-233.

Nielson, F.D. (1967) Modulus of Soil Reaction as Determined from Triaxial Shear Test, Highway Research Record No.185, Washington, D.C., pp.80-90.

OCPA, Ontario Concrete Pipe Association: Concrete Pipe Installation Pocket Guide [Online]. (2010). Available: http://www.ocpa.com

Petroff, L. J. (1990) Review of the Relationship between Internal Shear Resistance and Arching in Plastic Pipe Installations. Buried Plastic Pipe Technology, ASTM STP 1093, Buczala, G.S., and Cassady, M.J (eds), American Society for Testing and Materials, Philadelphia, USA.

Petroff, L.J. (1993) Ring Bending Stiffness and the Design of Flexible Pipe. Structural Performance of Pipes, Proceedings of the Second Conference on Structural Performance of Pipes, Sargand, G.F., Mitchell, G.F., \& Hurd, J.O (eds), March 14-17, Columbus, Ohio, pp.125-136.

Pirtz, D. (1968) Creep Characteristics of Mass Concrete for Dworshak Dam, Report No, 65-2, Structural Engineering Laboratory, University of California, Berkeley, California. 
PPI, Plastic Pipe Institute [Online]. (2005) Available http:// www.plasticpipe.org,[2005].

Reddy, D.V., and Ataoglu, S. (2002) Experimental Analysis of Buried High Density Polyethylene pipes. Turkish Journal of Engineering and Environmental Sciences, Vol. 26, pp. 293-300.

Ross, A.D. (1937) Concrete Creep Data. The Structural Engineer, Vol. 15, No .8, pp. 314326.

Sargand, S.M. and Masada, T. (2007), Long-Term Monitoring of Pipe under Deep Cover, Final Report, Ohio Research Institute for Transportation and the Environment (ORITE)

Sargand, S.M., and Masada, T. (2000) Performance of Large-Diameter Honeycomb-design HDPE pipe under a Highway Embankment. Canadian Geochemical Journal, NRC Research Press Website, October 25, Vol. 37, pp. 1099-1108.

Sargand, S.M., Mitchell, G.F., and Hurd, J.O.,(1993) Proceedings of the Second Conference on Structural Performance of Pipes, March 14-17, Columbus, Ohio.

Sargand, S.M., Mitchell, G.F., and White, K. (1998), Proceedings of the Third Conference on Structural Performance of pipes, March 22-24, Athens, Ohio.

Schrock, B.J. (1990) Technical Work on Flexible Pipe/Soil Interaction Overview. Pipeline Design and Installation, Proceedings of the International conference on pipeline design and installation, Kienow, K.K. (eds), March 25-27, Las Vegas, Nevada, pp. 351-362.

Selig, E.T. (1988) Soil Parameter for Design of Buried Pipelines. Pipeline Infrastructure; Proceedings of the Conference, June 6-7, Boston, Massachusetts.

Smeltzer, P.D. and Daigle, L. (2005) Field Performance of a Concrete Pipe Culvert Installed using Standard Installations. 33 Annual General Conference of the Canadian Society for Civil Engineering, Toronto, Ontario, June 2-4, 2005, pp. 210-1 - 210-13.

Soleno, Inc., Technical manual: Characteristics of corrugated HDPE pipe [Online]. (2005) Available: http://soleno.com, [2005].

Spangler, M.G. (1941) The Structural Design of Flexible Pipe Culverts. Bulletin 153, Iowa Engineering Experiment Station, Ames, Iowa, USA.

Suleiman, M.T. and Coree, B.J. (2004) Constitutive Model for High Density Polyethylene Material: Systematic Approach. Journal of Materials in Civil Engineering, Vol. 16, No. 6.

Uni-Bell PVC Pipe Association: Literature and software [Online]. (2010) Available: http:// www.uni-bell.org, (2010). 
Watkins, R.K. and Spangler, M.G. (1958) Some Characteristics of the Modulus of Passive Resistance of Soil: A Study in Similitude. Highway Research Board, Proceedings of the 37th Annual Meeting, January, Vol. 37, pp. 576-583.

Watkins, R.K., and Anderson, L.R. (1999) Structural Mechanics of Buried Pipes. CRC press, New York.

Webb, M.C., McGrath, T.J., and Selig, E.T. (1998) Field Test of Buried Pipe with CLSM Backfill. The Design and Application of Controlled Low- Strength Materials (Flowable Fill), ASTM STP 1331, A.K.Howard and J.L.Hitch, Eds., American Society for Testing and Materials.

Willoughby, D.A. (2002) Plastic Piping Handbook. McGraw-Hill, Inc., New York.

Zhang, C., and Moore, I. D. (1998) Nonlinear Finite Element Analysis for Thermoplastic Pipes. Transportation Research Record 1624, Transportation Research Board, Washington, D.C., pp. 225-230. 